\title{
DARK-BLUE HORIZON: SEA LEVEL RISE AND METEOTSUNAMIS ON THE FINNISH COAST
}

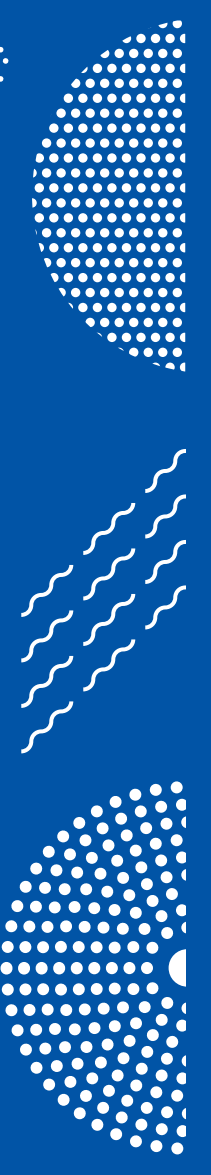

HAVU PELLIKKA 
FINNISH METEOROLOGICAL INSTITUTE

CONTRIBUTIONS

No. 167

\section{DARK-BLUE HORIZON}

SEA LEVEL RISE AND METEOTSUNAMIS ON THE FINNISH COAST

Havu Pellikka

Institute for Atmospheric and Earth System Research

Faculty of Science

University of Helsinki

Helsinki, Finland

DOCTORAL DISSERTATION in geophysics

To be presented for public discussion, with the permission of the Faculty of Science of the University of Helsinki, in auditorium P674, Porthania (Yliopistonkatu 3, Helsinki) on the $25^{\text {th }}$ of June, 2020 , at 12 o' clock noon.

Finnish Meteorological Institute

Helsinki, 2020 
Supervisors

Dr. Milla Johansson

Marine Research Unit

Finnish Meteorological Institute

Helsinki

Finland

Pre-examiners Prof. Tarmo Soomere

Laboratory of Wave Engineering

Tallinn University of Technology

Tallinn

Estonia

Opponent

Dr. Ralf Weisse

Institute for Coastal Research

Helmholtz-Zentrum Geesthacht

Geesthacht

Germany

Custos

Prof. Petteri Uotila

Institute for Atmospheric and Earth System Research

Faculty of Science

University of Helsinki

Helsinki

Finland
Prof. Kimmo Kahma

Marine Research Unit

Finnish Meteorological Institute

Helsinki

Finland

Prof. Malgorzata Stramska

Institute of Oceanology

Polish Academy of Sciences

Sopot

Poland

The Faculty of Science uses the Urkund system (plagiarism recognition) to examine all doctoral dissertations.

\author{
ISBN 978-952-336-111-9 (paperback) \\ ISBN 978-952-336-112-6 (pdf) \\ ISSN 0782-6117 \\ Edita Prima Oy \\ Helsinki 2020
}


Published by Finnish Meteorological Institute

(Erik Palménin aukio 1), P.O. Box 503

FIN-00101 Helsinki, Finland
Series title, number and report code of publication

Finnish Meteorological Institute

Contributions 167, FMI-CONT-167

Date

May 2020

ORCID iD

Author

Havu Pellikka https:/ / orcid.org/0000-0001-8835-5831

Title

Dark-blue horizon: Sea level rise and meteotsunamis on the Finnish coast

\section{Abstract}

This thesis presents research on two topics related to sea level in the Baltic Sea: regional sea level rise and meteotsunamis, i.e. meteorologically generated tsunami waves. While these phenomena act on very different time scales, they are both relevant for estimates of coastal flooding risks. Main objectives of this work are i) to present projections of mean sea level change in Finland by 2100 as location-specific probability distributions that can be used as a basis for decision-making in coastal management, and ii) to study the occurrence of meteotsunamis on the Finnish coast and the weather conditions that create these waves.

Global mean sea level is rising in the warming climate. This will affect coastal life worldwide, but sea level does not rise uniformly around the globe. Projections of future sea level rise have large uncertainties, especially because the response of the Antarctic ice sheet to climatic changes is poorly known. This makes the upper tail of the probability distribution of sea level rise hard to pin down. In this work, an ensemble of global sea level rise projections is adjusted regionally to form a probability distribution of regional sea level rise. The results suggest that sea level rise in the Baltic Sea will be about $80 \%$ of the global mean, without including the effect of land uplift.

To obtain probability distributions of mean sea level change relative to land, the effects of postglacial land uplift and wind-induced changes in mean sea level are combined with the sea level rise distributions. According to the average scenario, the sea level in the Gulf of Finland is expected to rise ca. $30 \mathrm{~cm}$ in 2000-2100, while mean sea level decline will continue in the Gulf of Bothnia. However, the high-end scenario projects sea level rise everywhere on the Finnish coast, ranging from $21 \mathrm{~cm}$ in Vaasa to $90 \mathrm{~cm}$ in Hamina.

Meteotsunamis occur in shallow sea areas worldwide and can reach a height of several metres in extreme cases. In the Baltic Sea, such high, inexplicable sea waves are historically known as Seebär on the German-speaking southern coast and sjösprång in Swedish-speaking regions. According to old literature and recent eyewitness reports, meteotsunamis can occur all around the Baltic Sea and cause mild damage. The highest reliably documented events have been 1-1.5 metres high.

After decades of no reported occurrences, three meteotsunamis were observed in Finland in the summers of 2010 and 2011. This work gives a detailed description of these events and their meteorological origin. The waves were created by air pressure disturbances propagating over the sea. The speeds of the disturbances were close to the long wave speed in the sea, which amplifies the wave. Such resonance effects, in addition to local coastal bathymetry, are central in the formation of meteotsunamis.

To study the frequency of meteotsunami occurrence on the Finnish coast, meteotsunamis were detected in the original tide gauge charts and high-resolution sea level data from the Gulf of Finland over the past century. In total, 121 potential events were identified in the summer months of 1922-2014, with typical wave heights of 10-30 cm at the tide gauges. A statistically significant increasing trend in the number of meteotsunamis was found in Hamina in the eastern part of the gulf, but not in Hanko in the west. A strong connection between lightning observations (1998-2014) and meteotsunami occurrence was found: lightning numbers were over ten times higher on days when a meteotsunami was recorded compared to other summer days.

Publishing unit

Finnish Meteorological Institute, Marine Research Unit

\begin{tabular}{|c|c|c|}
\hline $\begin{array}{l}\text { Classification (UDC) } \\
551.461 \\
551.466\end{array}$ & & $\begin{array}{l}\text { Keywords } \\
\text { sea level, sea level rise, coastal flooding, } \\
\text { meteotsunamis, Baltic Sea }\end{array}$ \\
\hline $\begin{array}{l}\text { ISSN and series title } \\
\text { 0782-6117 Finnish Meteorological Institute Con }\end{array}$ & ributions & $\begin{array}{l}\text { ISBN } \\
\text { 978-952-336-111-9 (paperback) } \\
978-952-336-112-6 \text { (pdf) }\end{array}$ \\
\hline $\begin{array}{l}\text { DOI } \\
\text { https:// doi.org/10.35614/isbn. } 9789523361126\end{array}$ & $\begin{array}{l}\text { Language } \\
\text { English }\end{array}$ & $\begin{array}{l}\text { Pages } \\
58\end{array}$ \\
\hline
\end{tabular}


Julkaisija Ilmatieteen laitos

(Erik Palménin aukio 1)

PL 503, 00101 Helsinki
Julkaisun sarja, numero ja raporttikoodi

Finnish Meteorological Institute

Contributions 167, FMI-CONT-167

Päiväys

Toukokuu 2020

ORCID iD

https:/ / orcid.org/0000-0001-8835-5831

Tekijä Havu Pellikka

Nimeke

Sinimusta horisontti: Merenpinnan nousu ja säätsunamit Suomen rannikolla

\section{Tiivistelmä}

Tässä työssä käsitellään kahta Itämeren vedenkorkeuteen liittyvää aihetta: alueellista merenpinnan nousua ja säätsunameja eli meteorologisten ilmiöiden synnyttämiä tsunamiaaltoja. Vaikka ilmiöiden aikaskaalat ovat hyvin erilaiset, ovat ne molemmat olennaisia Itämeren meritulvariskien arvioinnin kannalta. Työn tärkeimpinä tavoitteina on i) laskea ennusteet keskimerenpinnan tason muutokselle Suomessa vuoteen 2100 saakka paikkakohtaisina todennäköisyysjakaumina, jotka sopivat käytettäväksi päätöksenteon tukena rannikkosuunnittelussa, sekä ii) tutkia säätsunamien esiintymistä Suomen rannikolla ja niihin liittyviä sääolosuhteita.

Ilmaston lämpenemisen aiheuttama valtamerien pinnannousu vaikuttaa rannikkoseutujen elämään ympäri maailman, mutta merenpinta ei nouse tasaisesti kaikkialla. Merenpinnan nousuennusteissa on myös suuria epävarmuuksia erityisesti siksi, että Etelämantereen mannerjäätikön tulevaisuus muuttuvassa ilmastossa tunnetaan huonosti. Sen vuoksi merenpinnan nousun todennäköisyysjakauman yläpäätä on vaikea arvioida. Tässä työssä käytetään alueellisen merenpinnan nousun jakauman pohjana joukkoa globaaleja ennusteita, joihin sovelletaan alueellisia korjaustekijöitä. Tulosten perusteella merenpinnan nousu Itämerellä on noin 80 \% globaalista keskiarvosta, jos ei huomioida maankohoamisen vaikutusta.

Kun merenpinnan nousujakaumiin lisätään maankohoamisen ja tuulen aiheuttamien keskimerenpinnan muutosten vaikutus, saadaan todennäköisyysjakaumat keskimerenpinnan tason muutoksesta maan suhteen. Keskimääräisen skenaarion mukaan merenpinta nousee Suomenlahdella noin $30 \mathrm{~cm}$ vuosina 2000-2100, kun taas Pohjanlahdella merenpinta edelleen laskee. Korkeimpien ennusteiden toteutuminen johtaisi kuitenkin merenpinnan nousuun kaikkialla Suomen rannikolla nousun vaihdellessa Vaasan 21 cm:stä Haminan 90 cm:iin.

Säätsunameja esiintyy matalilla merialueilla ympäri maailmaa ja ne voivat saavuttaa ääritapauksissa useiden metrien korkeuden. Itämeren piirissä tällaiset korkeat, selittämättömät aallot tunnetaan vanhastaan saksankielisellä nimellä Seebär ja ruotsinkielisellä nimellä sjösprång. Vanhojen kirjallisuuslähteiden ja uusien silminnäkijähavaintojen perusteella säätsunameja esiintyy kaikkialla Itämeren rannikolla ja ne voivat aiheuttaa lievää vahinkoa. Suurimmat luotettavasti dokumentoidut tapaukset ovat olleet 1-1,5 metrin korkuisia.

Useiden vuosikymmenten mittaisen hiljaisen jakson jälkeen Suomessa havaittiin kolme säätsunamia kesällä 2010 ja 2011. Tässä työssä kuvataan nuo tapaukset ja niiden meteorologinen tausta yksityiskohtaisesti. Aallot syntyivät meren yllä liikkuvien ilmanpaineen häiriöiden seurauksena. Häiriöiden nopeus oli lähellä pitkien aaltojen nopeutta meressä, mikä kasvattaa aallon korkeutta. Tällaiset resonanssi-ilmiöt ovat rannikon paikallisen pohjatopografian lisäksi keskeisiä säätsunamien muodostumisessa.

Ilmiön yleisyyden tutkimiseksi säätsunameja etsittiin Suomenlahden mareografien alkuperäisiltä piirturirullilta ja korkean resoluution vedenkorkeushavainnoista lähes vuosisadan ajalta. Aineistosta tunnistettiin kaikkiaan 121 potentiaalista säätsunamia kesäkuukausilta 1922-2014; aaltojen tyypillinen korkeus mareografeilla oli 10-30 cm. Säätsunamien lukumäärässä havaittiin tilastollisesti merkitsevä lisääntyvä trendi Haminassa, mutta ei Hangossa. Salamahavaintojen (1998-2014) ja säätsunamien esiintymisen välillä havaittiin selvä yhteys: salamamäärät olivat yli kymmenkertaisia säätsunamien esiintymispäivinä verrattuna muihin kesäpäiviin.

Julkaisijayksikkö

Ilmatieteen laitos, Merentutkimus

Luokitus (UDK)

551.461

551.466

ISSN ja avainnimeke

0782-6117 Finnish Meteorological Institute Contributions

Asiasanat

vedenkorkeus, merenpinnan nousu, rannikkotulvat, säätsunamit, Itämeri

\section{ISBN}

978-952-336-111-9 (paperback) 978-952-336-112-6 (pdf)

\begin{tabular}{lll}
\hline $\begin{array}{l}\text { DOI } \\
\text { https://doi.org/10.35614/isbn.9789523361126 }\end{array}$ & $\begin{array}{l}\text { Kieli } \\
\text { englanti }\end{array}$ & $\begin{array}{l}\text { Sivumäärä } \\
58\end{array}$ \\
\hline
\end{tabular} 


\section{Preface}

The name of this thesis, Dark-blue horizon, quotes an eyewitness account of a meteotsunami in the Gulf of Finland on 26 July 1876 (p. 39). Metaphorically, it refers to the projections of increasing coastal flooding risks in the future. It is my wish that this work would be of interest to coastal dwellers and serve societies in adapting to the changing conditions of our future.

It takes many people to complete a doctoral dissertation. First of all, I want to thank my supervisors for all their support: Kimmo Kahma for his admirable enthusiasm, deep expertise and endless ideas, and Milla Johansson for often saving the day with her calm and reassuring reasoning, besides being excellent company in all kinds of excursions into the wild Finnish nature. Professors Matti Leppäranta and Petteri Uotila are acknowledged for their gentle encouragement as well as for smoothly sorting out practical matters. I thank Professors Malgorzata Stramska and Tarmo Soomere for pre-examining this thesis, and Ralf Weisse for taking the time to act as the opponent.

I wish to thank all the co-authors of the papers for their work and dedication. Without their efforts this thesis would not exist. Special thanks to Anu Karjalainen and Hanna Boman who spent weeks carefully going through and digitizing old sea level observations, stored on paper rolls in the basement of the institute.

The flexibility and support of my boss Lauri Laakso was critically important when things got difficult, and he can largely be thanked, or blamed, for the fact that this thesis is now completed. My dear friend and colleague Jan-Victor Björkqvist has often been the first person to turn to at moments of despair and his help over the years is greatly appreciated. I also wish to thank Peter Eriksson and Jani Särkkä for help with translation problems, and Leena Kahma and Marina Kurtén for proofreading.

I am grateful to Jadranka Šepić and Ivica Vilibić for the hospitality they showed in welcoming me to visit the Institute of Oceanography and Fisheries in Split for a couple of months in 2015-2016. Even though it coincided with a dark period in my personal life, I have warm memories from this time in Croatia and my studies on meteotsunamis greatly benefitted from their knowledge. I also wish to thank Ola Kalén for sharing information on Swedish meteotsunamis.

The most important source of funding over my years in sea level science have been the Finnish Research Programmes for Nuclear Power Plant Safety (SAFIR). I thank Kirsti Jylhä for her work in steering the EXWE project over the years, always in a friendly and patient manner despite the often high pressure with tight deadlines.

The work described in this thesis was carried out in the Marine Research Unit of the Finnish Meteorological Institute. Highlights of these years have been the research expeditions on $R / V$ Aranda, bringing some salty water, seasickness and glorious sunrises to the research life where one so easily gets buried in numbers and computer code. 
Thank you, all colleagues in the Finnish marine research community - special thanks to Simo for hosting innumerable Simo-Kino movie nights, Ulpu and Victor for making music together in Kolmihuippuinen spektri, and Elina for trying (and inevitably failing) to get me to work before lunchtime. I am deeply grateful to Meri for offering help when I most needed it.

I thank my family and friends, both former and current, for all their love and support. Ani, my dear four-legged companion, has helped me to stay connected with our common basic needs and took care of getting me outside during the days of writing. My partner Anna has been the greatest support during the past couple of years, and her encouragement to find my own paths and listen to my needs has been invaluable. I hope her life will become easier now that I am turning over a new leaf.

Lastly, I want to honour all the different parts within me, those that had to suffer and those that wanted to see this work finished some day. The last phases of this work have been a learning process of self-compassion, and I hope that this process will continue and bear fruit in the coming days and years.

In Luova Kasvu, Espoo

May 2020

Havu Pellikka 


\section{Contents}

$\begin{array}{lr}\text { List of original publications } & 8\end{array}$

1 Introduction $\quad 10$

2 Background 13

2.1 Sea level changes in the Baltic Sea . . . . . . . . . . . . . . . . . . . . 13

2.1.1 Short-term variations and extremes . . . . . . . . . . 13

2.1 .2 Long-term changes . . . . . . . . . . . . . . . . 15

2.2 Sea level rise: past and future $\ldots \ldots \ldots \ldots \ldots \ldots \ldots \ldots$

2.2.1 Geological context and sources of sea level rise . . . . . . . . 16

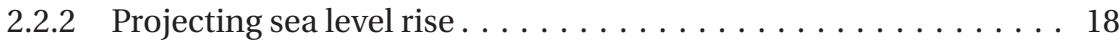

2.2.3 Largest source of uncertainty: dynamical changes in ice sheets . 20

2.2.4 Regional deviations from the global mean . . . . . . . . . . . 22

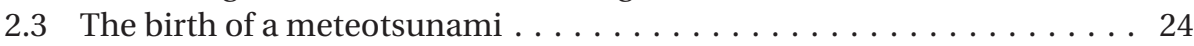

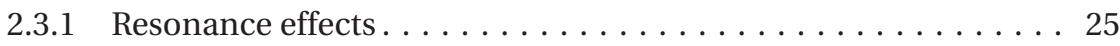

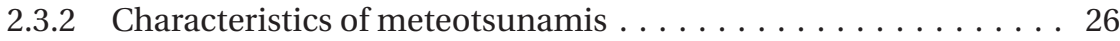

3 Sea level projections for the Finnish coast 27

3.1 Main components of long-term sea level change . . . . . . . . . . . 28

3.1.1 Adapting global projections to the Finnish coast . . . . . . . . . 28

3.1 .2 Changes in wind climate $\ldots \ldots \ldots \ldots \ldots$

3.1 .3 Land uplift . . . . . . . . . . . . . . . . . 31

3.2 Future change in mean sea level in Finland . . . . . . . . . . . . . 32

4 Meteotsunamis in the Baltic Sea $\quad 35$

4.1 Historical events in the Baltic Sea $\ldots \ldots \ldots \ldots \ldots \ldots \ldots \ldots$

4.1 .1 Seebär in the southern Baltic Sea . . . . . . . . . . . . . . . 36

4.1.2 Historical events in Finland . . . . . . . . . . . . . . . . . 39

4.2 Recent events . . . . . . . . . . . . . . . . . . . . . . . . . . 40

4.2 .1 Recent meteotsunamis in Finland . . . . . . . . . . . . . . . 40

4.2.2 Recent meteotsunamis in Sweden . . . . . . . . . . . . . . . . . . 41

4.3 Meteotsunamis in Finnish sea level data over the past century . . . . . . 42

4.4 Connection to atmospheric phenomena . . . . . . . . . . . . 43

5 Discussion $\quad 45$

6 Conclusions $\quad 48$

$\begin{array}{lr}\text { References } & 49\end{array}$ 


\section{List of original publications}

I Johansson M.M., Pellikka H., Kahma K.K., and Ruosteenoja K., 2014. Global sea level rise scenarios adapted to the Finnish coast. Journal of Marine Systems 129, 35-46. DOI: 10.1016/j.jmarsys.2012.08.007

II Pellikka H., Rauhala J., Kahma K.K., Stipa T., Boman H., and Kangas A., 2014. Recent observations of meteotsunamis on the Finnish coast. Natural Hazards 74, 197-215. DOI: 10.1007/s11069-014-1150-3

III Pellikka H., Leijala U., Johansson M.M., Leinonen K., and Kahma K.K., 2018. Future probabilities of coastal floods in Finland. Continental Shelf Research 157, 32-42. DOI: 10.1016/j.csr.2018.02.006

IV Pellikka H., Laurila T.K., Boman H., Karjalainen A., Björkqvist J.-V., and Kahma K.K., 2020. Meteotsunami occurrence in the Gulf of Finland over the past century. Natural Hazards and Earth System Sciences Discussions, in review. DOI: 10.5194/nhess-2020-3

\section{Author contributions}

In Paper I, the author was responsible for calculating the regional sea level rise projections, with support from the co-authors, and wrote sections 4.1-4.4. The paper was also part of Milla Johansson's PhD thesis (Johansson, 2014). In Paper II, the author performed the analyses of sea level and air pressure data and wrote most of the paper. In Paper III, the author calculated the mean sea level projections and was mainly responsible for writing the paper in collaboration with all co-authors. In Paper IV, the author coordinated the study, had a leading role in the data analyses and wrote most of the paper. The author is fully responsible for the summary. Note that the given name of the author changed in 2016. 
...vi ha för oss en orkester av tusen instrument, höga toner av kort våglängd och djupa undertoner som korrespondera mot skvalpningarna $i$ hela Östersjöbäckenet, och jag vågar påstå att partituret aldrig blir i alla detaljer uttytt.

...we have an orchestra of a thousand instruments, high tones of short wavelengths and deep undertones that correspond to oscillations in the whole Baltic Sea basin, and I dare say that the score will never be explained in full detail.

- Henrik Renqvist: Ett sjösprång, 1926 


\section{Introduction}

Coastal zones are more densely populated than other areas on Earth, and sea level changes play an important role in life on the coast. In 2000, 640 million people (about $11 \%$ of the world population) were living less than $10 \mathrm{~m}$ above mean sea level, with the number expected to grow to more than one billion by 2050 (Merkens et al., 2016) Understanding sea level changes on different time scales is crucial for coastal safety, especially in our time when rising sea levels threaten coastal societies and ecosystems worldwide.

The Baltic Sea, the region of interest in this work, is a small and shallow marginal sea of the Atlantic Ocean. Its mean depth of $54 \mathrm{~m}$ is tiny in comparison to the mean depth of all oceans, $3.8 \mathrm{~km}$ (Sverdrup et al., 1942), and the narrow ocean connection makes it a nearly enclosed basin of brackish water. The Fennoscandian land uplift, a relic of the last ice age, shelters the northern Baltic coasts from the worst consequences of sea level rise. However, changes in the world's oceans affect life around the Baltic Sea as well. The interconnectedness of the Earth system is clearly demonstrated by sea level rise: as a result of an imbalance in the carbon cycle, remote polar ice masses are melting and ocean waters are warming up and expanding, and the implications are felt everywhere on the world's coastlines.

With the global mean sea level steadily rising, sea level researchers are striving to answer the critical question: how fast will sea levels rise in the coming decades and centuries? Future sea level rise is a complicated research question that involves all parts of the climate system and their interactions, as well as societal changes and political decisions. Some perspective can be gained from geological evidence of past changes, but with anthropogenic climate change we are venturing into unknown terrain (Zeebe et al., 2016). Sea level rise projections are subject to deep uncertainty (Bakker et al., 2017), and the uncertainty has not diminished even after 35 years of research (Garner et al., 2018). In fact, the more the research has advanced, the more we understand about the complexity of the problem.

On the other hand, the fast advancement in technology means that changes in the Earth system are being monitored more accurately than ever. The improved accuracy results in many phenomena being revealed that were previously unknown or poorly understood. An example of such a phenomenon is the meteotsunami, a meteorologically generated tsunami wave that can locally reach a height of several metres and cause catastrophic flooding (Monserrat et al., 2006). Even though sea level measurements have a long history - in Finland, for example, the first self-recording tide gauge started operation in 1887 in Hanko - we can still make new discoveries in the sea level data. 
This thesis wraps up findings from four papers. Two of them (Papers I and III) deal with future changes in mean sea level in the Baltic Sea, more specifically on the coast of Finland. These studies were motivated by the needs of Finnish society to prepare for future changes in mean sea level. The other two papers (Papers II and IV) study meteotsunamis on the Finnish coast. While their occurrence in the Baltic Sea has long been known (Credner, 1889; Doss, 1906; Meissner, 1924; Renqvist, 1926a), knowledge on Baltic meteotsunamis has been scarce and mainly based on eyewitness reports. The two papers included in this thesis are the first modern scientific publications on meteotsunamis in the Baltic Sea.

The sea level changes discussed in this thesis encompass a wide range of temporal and spatial scales. Meteotsunamis are local events with a typical duration of a few hours or less, and even though they can be observed on a wide stretch of the coastline, potentially dangerous fluctuations are generally restricted to individual bays or harbours. The adverse effects of large-scale sea level rise, on the other hand, unfold slowly over the coming decades and centuries and are felt globally, even though regional differences are significant. Yet these phenomena at the opposite ends of the sea level spectrum are both relevant in evaluating coastal flooding risks, and it is at the ends of the spectrum where the most unknown research areas lie.

Harmful effects of sea level rise include more frequent and intense flooding, shoreline erosion, inundation of land and forced migration, saltwater intrusion to arable land and freshwater sources, and degradation of coastal ecosystems (e.g. Oppenheimer et al., 2019). Extreme sea level events, on the other hand, may cause flooding of buildings and other coastal infrastructure as well as challenges to navigation and safety in marine transport. These impacts can have many adverse consequences, from loss of life to financial damage and costs of flood protection, and threaten critical functions of society. In Finland, recent research on mean sea level changes and extreme sea level events has been largely motivated by i) the need to regulate building elevations and minimize flooding risks through coastal planning, and ii) the safety of coastal nuclear power plants. Flooding of the critical compartments of a nuclear power plant would have severe consequences; therefore even extremely rare events need to be considered in the safety assessments (Jylhä et al., 2018).

The main research objectives of this thesis are:

1. To present projections of mean sea level change in Finland by 2100 that are based on current scientific understanding, cover the whole probability range and are easily applicable in coastal management (Papers I and III)

2. To investigate the frequency of meteotsunami occurrence on the Finnish coast through an extensive analysis of sea level data from the past century (Paper IV)

3. To discover what kind of weather phenomena are connected to meteotsunamis occurring on the Finnish coast (Papers II and IV) 
This summary presents the main findings of the four papers and sets them in a wider scientific context. It also aims to serve as an introduction to the topics of sea level rise and meteotsunamis to a wide range of readers from different backgrounds. In Chapter 2, I introduce the main factors influencing the variations in the Baltic Sea level, the sources of global sea level rise, its uncertainties and projection methods, as well as the characteristics and the generation mechanism of meteotsunamis. Chapter 3 discusses future changes of mean sea level in Finland, taking into account global sea level rise and its regional deviations, postglacial land uplift, and changes in the wind climate. In Chapter 4, I will first give an overview of historical accounts of meteotsunamis - locally called Seebär - in the Baltic Sea and then move on to describe recent events on the Finnish coast, meteotsunami occurrences over the past century and their connection to atmospheric conditions. Finally, Chapter 5 presents discussion and outlooks for future research, and Chapter 6 summarizes the most important findings. 


\section{Background}

\subsection{Sea level changes in the Baltic Sea}

As a small, semi-enclosed inland sea, the Baltic Sea (Fig. 1) has a characteristic sea level dynamics quite unlike that of most coastal areas in the world. Geographical features that affect the sea level dynamics are the narrow ocean connection in the Danish straits and the complex shape of the coastline. The Danish straits consist of three narrow straits, the Great Belt (smallest width $16 \mathrm{~km})$, the Little Belt $(1 \mathrm{~km})$, and Öresund $(4 \mathrm{~km})$, with a depth mostly under $20 \mathrm{~m}$. The largest archipelago of the Baltic Sea is the Archipelago Sea between the Gulf of Bothnia and the Gulf of Finland, an enormously complex maze of thousands of islands. The Finnish and Swedish coasts in the north are more complex and broken in general and made up of solid rock, while the southern Baltic coastline is more sandy and predominantly smooth.

The sea level records from the Baltic Sea are among the longest in the world. In Stockholm (Sweden), systematic sea level measurements started in 1774 with weekly readings (Ekman, 1988). Long records from the early $19^{\text {th }}$ century also exist from Kronstadt (Russia), Travemünde (Germany), and Swinemünde (currently Świnoujście, Poland), and more stations emerged during the $19^{\text {th }}$ century (Hünicke et al., 2017). Selfrecording instruments were installed around 1890 in many Baltic countries. While continuous measurements may exist on the original paper recordings of the tide gauges, digital sea level data with a sampling interval of less than one hour has become available relatively recently. For example, hourly data from many Swedish stations is available from 1886, 10-min data from around 1995, and 1-min data from the past couple of years (Ola Kalén, pers. comm.).

In Finland, sea level observations with tide poles started in the mid- $19^{\text {th }}$ century, and a self-recording tide gauge network consisting of 13 stations was established between 1887 and 1933. The continuously plotting pen-and-ink recorders of the tide gauges were replaced by digital ones around 1990. Digitized measurements are available for every 4 hours before 1970, hourly measurements after that. In addition, raw 15-min data is available since the beginning of the 1980s and 1-min data since 2004. The original tide gauge recordings have been preserved and high-resolution data is thus available nearly over the whole time series since the tide gauge network was established, but most of this data has not been digitized.

\subsubsection{Short-term variations and extremes}

Short-term sea level variations, caused both by external forcing through the Danish straits and by internal variations within the Baltic Sea basin, are largely controlled by 


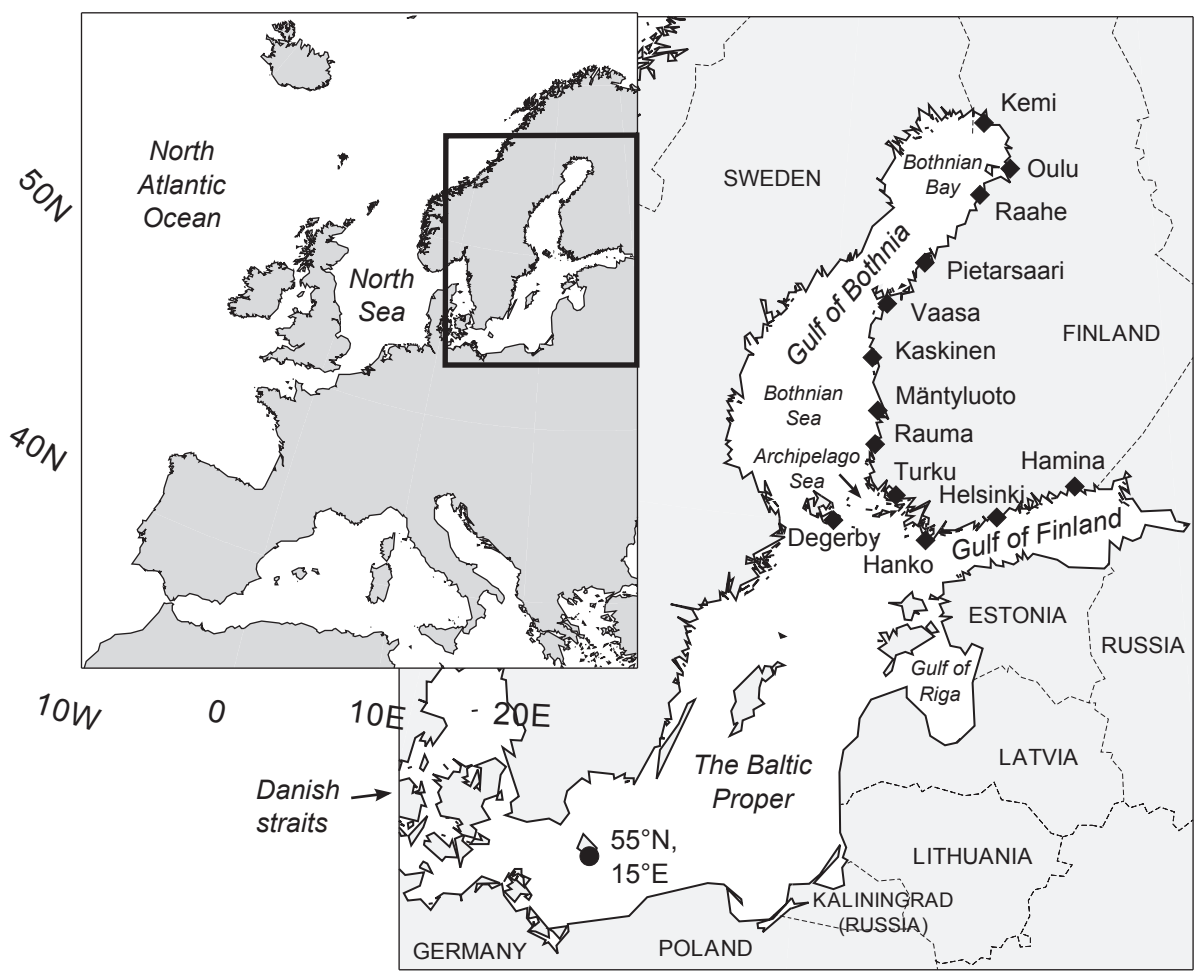

Figure 1: Map of the study area, the Baltic Sea. Finnish tide gauges, from which sea level data was used in this work, are marked with diamonds. The point $55^{\circ} \mathrm{N}, 15^{\circ} \mathrm{E}$, marked with a dot, is related to the analysis of wind-induced changes in mean sea level on the Finnish coast.

wind and air pressure conditions over the region. In simplified terms, strong westerly winds push water through the straits into the Baltic Sea, while easterly winds lead to declining sea level in the Baltic. The limited water exchange between the North Sea and the Baltic Sea through the narrow Danish straits plays a very significant role in Baltic sea level variations. The Baltic Sea acts effectively as a closed basin for sea level variations shorter than about one month, while longer-term changes can penetrate through the straits (Samuelsson and Stigebrandt, 1996). Winds affect also the distribution of water within the Baltic Sea basin by piling up water against the coast so that a slope in sea level is formed; westerly winds lead to higher sea levels on the eastern coasts of the sea and lower sea levels on the western side, and vice versa.

Johansson (2014) presented an overview of the magnitude of different factors causing sea level variations in the Baltic Sea. Changes in the water volume in the Baltic Sea basin introduce a natural variability of ca. $\pm 50 \mathrm{~cm}$ around the long-term mean (Vermeer et al., 1988). This variation comes primarily from the water exchange between the North Sea and the Baltic Sea; freshwater fluxes have a smaller effect 
(Vermeer et al., 1988; Samuelsson and Stigebrandt, 1996). Phenomena that regularly cause sea level variations of the order of several tens of centimetres include windinduced internal redistribution of water within the basin, air pressure variations, and seiches (standing waves) in the various sub-basins of the sea, large and small. The tidal range is so small - generally only a few centimetres (Witting, 1911; Medvedev et al., 2013) - that tides are often neglected in analyses of Baltic Sea level. They are not insignificant regarding flooding risks, however; for example, the maximum sea level reached in Helsinki during the record flood of January 2005 would have been $12 \mathrm{~cm}$ higher if the storm surge peak had coincided with the tidal maximum instead of the tidal minimum (Särkkä et al., 2017).

An extreme sea level event requires the simultaneous occurrence of several factors causing higher than normal sea levels. In the Baltic Sea, both the highest maxima and the lowest minima tend to occur during the winter months. The largest sea level variations are observed at the end of the elongated gulfs - the Gulf of Finland, the Gulf of Bothnia, and the Gulf of Riga - and near the Danish straits. The highest recorded storm surges have exceeded $3 \mathrm{~m}$ above the mean at the end of the Gulf of Finland and in the southwestern Baltic, and $2 \mathrm{~m}$ in the Gulf of Riga and at the end of the Gulf of Bothnia (e.g. Averkiev and Klevannyy, 2010; Wolski et al., 2014). Close to the open sea areas, the recorded maxima are generally 1-1.5 m above the mean. Among the most vulnerable locations for flooding is St. Petersburg at the end of the Gulf of Finland, where the dynamics of the river Neva also come into play. The most extreme floods the record being $421 \mathrm{~cm}$ in 1824 - have killed hundreds of people and badly damaged the city before the construction of the flood protection dam (Kulikov and Medvedev, 2013, 2017).

In Finland, recorded sea level maxima are 1-2 m above the mean. While coastal floods that cause notable damage are rare, extreme sea level events are a concern in coastal cities. For example, the storm surge of January 2005 that broke sea level records on the southern Finnish coast caused an economical damage of 12 million euros in Finland (Tulvariskityöryhmä, 2009).

The seasonal ice cover is another characteristic of the Baltic Sea that is relevant to short-term sea level variations. The length of the ice season is 5-7 months and the areal extent of the ice cover has large variation from year to year, ranging from $12.5 \%$ of the sea in mild conditions to $100 \%$ during extremely severe winters (Leppäranta and Myrberg, 2009). The ice cover reduces the wind stress on the sea surface (Lisitzin, 1957; Omstedt and Nyberg, 1991) and suppresses waves (Squire, 2018). Thus, it affects especially high-frequency sea level variations, but can also attenuate sea level variations in the time range of days and weeks.

\subsubsection{Long-term changes}

Long-term sea level changes in the northern Baltic Sea have historically been dominated by postglacial land uplift that has caused an apparent fall in mean sea level (e.g. 
Witting, 1918; Lisitzin, 1964; Ekman, 1988; Vermeer et al., 1988; Johansson et al., 2003). The Earth's crust is still slowly adjusting to the redistribution of mass caused by the last deglaciation. The removal of the huge weight of the ice sheets allows crustal recovery, resulting in land uplift in the deglaciated areas and sinking in the surrounding regions. After the instantaneous elastic rebound, the second phase involves the flow of viscous material in the Earth's mantle back to the deglaciated areas. This slow process takes tens of thousands of years, and even though the rate of land uplift decreases over time, on a time scale of centuries it can be considered linear.

The rate of land uplift is $10 \mathrm{~mm} / \mathrm{yr}$ in the northern Gulf of Bothnia, 2-4 mm/yr in the Gulf of Finland, and close to zero in the southern Baltic Sea at the German and Polish coasts (Vestøl et al., 2019). The rate of global mean sea level rise has accelerated over the $20^{\text {th }}$ century and currently amounts to $3.6 \mathrm{~mm} / \mathrm{yr}$ (Oppenheimer et al., 2019). Thus, the postglacial land uplift outweighs or significantly reduces the effect of sea level rise in the northern parts of the region.

In addition to the counteracting trends of global sea level rise and postglacial land uplift, changes in the water volume in the Baltic Sea basin play an important role in variations of the Baltic mean sea level (Johansson et al., 2003). These, in turn, are dominated by water exchange between the North Sea and the Baltic Sea. Variations in the water volume explain most of the year-to-year variability in annual mean sea levels and cause variation also on a time scale of decades (Johansson et al., 2004). As the water transport is regulated by wind and air pressure conditions, regional climatic changes may change the long-term average water volume of the Baltic Sea and hence the long-term mean sea level.

Changes in water density may also affect the volume of water in the Baltic Sea. There is a permanent salinity gradient within the sea, with more saline water $(25 \%$ o) near the Danish straits and salinity decreasing northwards so that it is close to zero at the opposite end. Because of the smaller water density, the sea level in the northeastern parts is 35-40 cm higher than in the Skagerrak outside the Danish straits (Ekman and Mäkinen, 1996). Changes in the freshwater fluxes and the salinity structure of the Baltic Sea may thus also induce significant long-term changes in Baltic Sea level. Current climate models generally predict increasing river runoff and decreasing salinity in the Baltic Sea, but as the models have severe biases in modelling the water balance, the magnitude and even the direction of future changes are uncertain (Meier, 2015).

\subsection{Sea level rise: past and future}

\subsubsection{Geological context and sources of sea level rise}

The Earth has seen large changes in the level of the oceans over geological history. The glacial-interglacial cycles of the Quaternary period (last 2.6 million years) have been accompanied by huge transports of water from the oceans to the continental ice sheets and back to the oceans when the ice sheets have melted, causing sea level variations 
of roughly 120-140 m (e.g. Rohling et al., 2009). In the geological perspective, the total volume of glaciers and ice sheets in our present warm interglacial period is small, yet it corresponds to ca. $65 \mathrm{~m}$ of sea level rise.

The oceans have risen above their present level during earlier warm climatic periods, such as the Last Interglacial 129-116 000 years ago, when the global mean temperature was $0.5-1.0^{\circ} \mathrm{C}$ warmer and global mean sea level $6-9 \mathrm{~m}$ higher, and the mid-Pliocene ca. 3 million years ago, when temperatures were $2-4^{\circ} \mathrm{C}$ warmer and sea level up to $25 \mathrm{~m}$ higher (Oppenheimer et al., 2019). While direct comparisons may be misleading, these warm periods give hints of the future in a warming climate: the rapid increase in greenhouse gas concentrations will eventually lead to a multi-metre rise in sea level unless steep reductions in global carbon emissions are achieved (Schaeffer et al., 2012; Levermann et al., 2013; Rohling et al., 2013; Winkelmann et al., 2015). The long response times of the ice sheets and deep ocean imply that it takes thousands of years for the global sea level to reach a new equilibrium. Because rapid changes challenge the ability of ecosystems and the human civilisation to adapt, the rate of sea level rise is even more critical for coastal societies than its eventual magnitude.

The sea level rise related to the last glacial-interglacial transition was stabilized some 2000 years ago, and the level of the oceans was rather stable before it started to rise again in the $19^{\text {th }}$ century. The rate of global mean sea level rise is accelerating: tide gauge and altimetry observations show a rise of $1.4 \mathrm{~mm} / \mathrm{yr}$ over the period 19011990, $2.1 \mathrm{~mm} / \mathrm{yr}$ in 1970-2015, $3.2 \mathrm{~mm} / \mathrm{yr}$ in 1993-2015, and $3.6 \mathrm{~mm} / \mathrm{yr}$ in 2005-2015 (Oppenheimer et al., 2019).

The causes of present-day sea level rise can be divided into two categories: eustatic rise, in which the amount of water in the ocean increases because water is transported to the oceans from other water reservoirs on Earth (glaciers, ice sheets and other freshwater sources), and steric rise, in which the amount of water stays the same but its volume increases, most notably through thermal expansion caused by warming of the sea water.

How water on Earth is distributed between different reservoirs gives an idea of the relative importance of various sources of sea level rise. Only $2.5 \%$ of all water on the planet is fresh water, and roughly $69 \%$ of the freshwater is found in glacial ice and $30 \%$ in groundwater - the remaining tiny fraction is divided between ground ice and permafrost $(0.86 \%)$, lakes $(0.26 \%)$, atmosphere $(0.04 \%)$, swamps $(0.03 \%)$, rivers $(0.006 \%)$, and biological water $(0.003 \%$; Shiklomanov, 1993$)$. Of all glacial ice, the majority is in the Antarctic ice sheet whose volume corresponds to $58 \mathrm{~m}$ of sea level rise, while the sea level equivalent of Greenland ice sheet is $7 \mathrm{~m}$, and that of all mountain glaciers and small ice caps roughly $0.5 \mathrm{~m}$ (Oppenheimer et al., 2019). Thus, the ice sheets of Antarctica and Greenland are by far the largest potential source of sea level rise. However, they react to environmental changes over long periods of time, over centuries and millennia. Small glaciers and ice caps are responsible for a large share of the $20^{\text {th }}$ century sea level rise as they react to global warming more quickly (Fig. 2), but their importance will diminish in the long term. Changes in other water reservoirs 


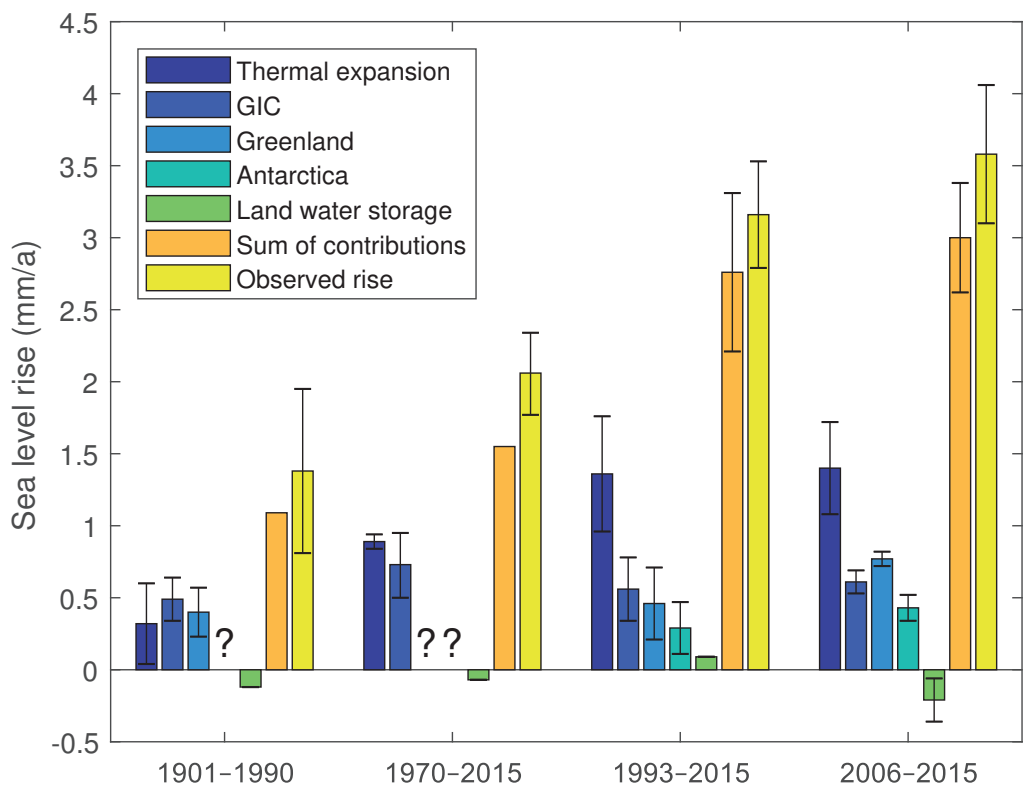

Figure 2: Rate of sea level rise and its sources during the instrumental period (1901-). Error bars show the 5-95\% uncertainty ranges. All values are based on observations except thermal expansion in 1901-1990, which is based on models. Frequent observations of ice sheet contributions are not available before the satellite era (1993 onwards); the Greenland contribution for 1901-1990 is based on a geodetic reconstruction. GIC = small glaciers and ice caps. Data from Oppenheimer et al. (2019).

play a minor role and are not well known, but water impoundment behind dams has a small negative effect on sea level rise and groundwater depletion a positive one (Wada et al., 2016).

The sources of sea level rise since the beginning of the $20^{\text {th }}$ century are presented in Figure 2. Thermal expansion is the dominant contributor, but as the ice loss from Greenland and Antarctica has accelerated, the combined effect of glaciers and ice sheets currently outweighs thermal expansion (Oppenheimer et al., 2019). The observed sea level rise is consistent with the sum of the different components since 1993, when frequent observations of ice sheet mass changes became available from satellite altimetry.

\subsubsection{Projecting sea level rise}

Present-day sea level rise is caused mainly by thermal expansion of sea water and melting of glaciers and ice sheets. Glaciers can lose mass in two ways: through surface melting (if melting is greater than mass accumulation through precipitation) and dynamical changes affecting the flow of ice into the sea. Out of the main contributors of sea level rise, the thermal expansion component and the surface mass balance of 
the glaciers and ice sheets are relatively well known, but dynamical changes in the ice sheets are not. Making reliable projections of future sea level rise requires deep understanding of processes regulating the movement of glacial ice in the ice sheets of Greenland and Antarctica, and many of the processes and interactions in the complex ice-ocean-atmosphere system are still poorly understood. Consequently, projections of global sea level rise have large uncertainties, especially in the low-probability, worstcase upper end of the scenario range.

Models used to project future sea level rise can be classified into two categories: process-based and semi-empirical. Process-based models are physical models that attempt to model each sea level rise contribution separately. The main problem in these models is projecting the dynamical component of ice sheet mass changes. Semiempirical models provide an alternative approach: they build on a statistical relation between global mean sea level and global mean temperature (or some other climate parameter), derived from past observations. This relation is then used together with model projections of future temperatures to obtain projections of future sea level. The method involves an inherent assumption that the observed relationship between global sea level rise and e.g. global temperature will hold in the future, too. Semiempirical projections cannot take into account processes that were not active during the observation period used to calibrate the model.

The sea level rise projections compiled by the Intergovernmental Panel on Climate Change (IPCC) carry the highest authority and are widely used in decision-making. The range of the IPCC sea level rise projections for the $21^{\text {st }}$ century has evolved as follows: 16-110 cm in the First Assessment report (FAR, 1990), 13-94 cm in the Second (SAR, 1996), 9-88 cm in the Third (TAR, 2001), 18-59 cm in the Fourth (AR4, 2007), and 28-98 cm in the Fifth (AR5, 2013). Most recently, in preparation for the Sixth Assessment Report, the IPCC published a special report on the ocean and cryosphere projecting 29-110 cm of sea level rise (Oppenheimer et al., 2019). All values are for 2100 (AR4 for 2090-2099) relative to a somewhat varying reference period at the end of the $20^{\text {th }}$ century. Beyond 2100, the uncertainties become so large that not many estimates exist in the literature.

The IPCC ranges are not directly comparable, because different approaches have been used especially regarding the most problematic dynamical ice sheet component (Section 2.2.3). However, it can be noted that the uncertainties have not diminished over time even though significant advances have been made in understanding and modelling the different contributors. The same can be seen in sea level projections in general: Garner et al. (2018), who compiled a comprehensive database of sea level projections since the early 1980s, concluded that central estimates of $21^{\text {st }}$ century sea level rise have been rather consistent, but the uncertainty limits have varied widely.

The IPCC has arguably been rather conservative in their sea level projections, and the upper limits given by the IPCC are significantly lower than the highest projections available in the literature (Garner et al., 2018). Because process-based models struggle with projecting future ice loss from Greenland and Antarctica and confidence 
in semi-empirical projections is considered low (Church et al., 2013a), the IPCC has not provided worst-case projections (Church et al., 2013b). The latest assessments are given with "medium confidence" which translates to "likely" (66-100\%) probability ranges. Because projections covering the whole probability range are needed in practical decision-making, it has become customary to complement the processbased projections with expert elicitations or other educated guesses to estimate the dynamical ice sheet component and obtain an upper limit for future sea level rise (e.g. Horton et al., 2014; Jevrejeva et al., 2014; Kopp et al., 2014). The publication of the IPCC AR4 was followed by a spurt of other published projections using semi-empirical models, probabilistic methodologies, and expert judgment that aim to explore the low-probability, high-end tail of the sea level rise distribution.

\subsubsection{Largest source of uncertainty: dynamical changes in ice sheets}

The understanding of dynamical changes in ice sheets has evolved rapidly in recent decades as more and more observational data has become available. There are many complex processes involved at the interface between the ice sheet and the ocean, where large floating ice shelves are formed (e.g. Joughin et al., 2012). Warming temperatures have resulted in increased melting both on the surface of the ice sheets and below the ice shelves (Mernild et al., 2011; Pritchard et al., 2012). Surface meltwater, in turn, can cause deepening of crevasses and penetrate through the ice, lubricating the flow of the ice sheet over its bed (Zwally et al., 2002; van der Veen, 2007; Joughin et al., 2008). This meltwater-driven fracturing of ice, together with other processes, has also contributed to the observed breakups of ice shelves (Scambos et al., 2000). While the loss of the floating ice shelves does not raise sea level directly, it can accelerate the flow of grounded ice, because ice shelves resist the flow of ice upstream if there are points of contact between the ice shelf and the ocean bottom or the coastline (Fig. 3d). Rapid speedups of glaciers feeding ice shelves that have broken up have indeed been observed e.g. in the Antarctic Peninsula (Rignot et al., 2004; Scambos et al., 2004).

The largest uncertainty in sea level rise projections, especially in northern latitudes, is the possible instability of the marine sectors of the Antarctic ice sheet (Mercer, 1978; Joughin and Alley, 2011). The collapse of these sectors was judged by the IPCC AR5 as the only mechanism that could cause the sea level to rise substantially above the projected likely range during the $21^{\text {st }}$ century (Church et al., 2013a). According to the marine ice sheet instability hypothesis, parts of an ice sheet that are in contact with the ocean and grounded below sea level, so that the bedrock is sloping down inland from the glacial front (as in Fig 3a, b), are prone to an irreversible, unstoppable collapse once the retreat of the front has begun (Weertman, 1974; Schoof, 2007). This theoretical instability mechanism concerns especially large parts of the West Antarctic ice sheet (WAIS), but also parts of the East Antarctic ice sheet (DeConto and Pollard, 2016). Recent observations indicate that the instability mechanism is real and already contributing to ice loss from WAIS (e.g. Favier et al., 2014; Rignot et al., 2014). 

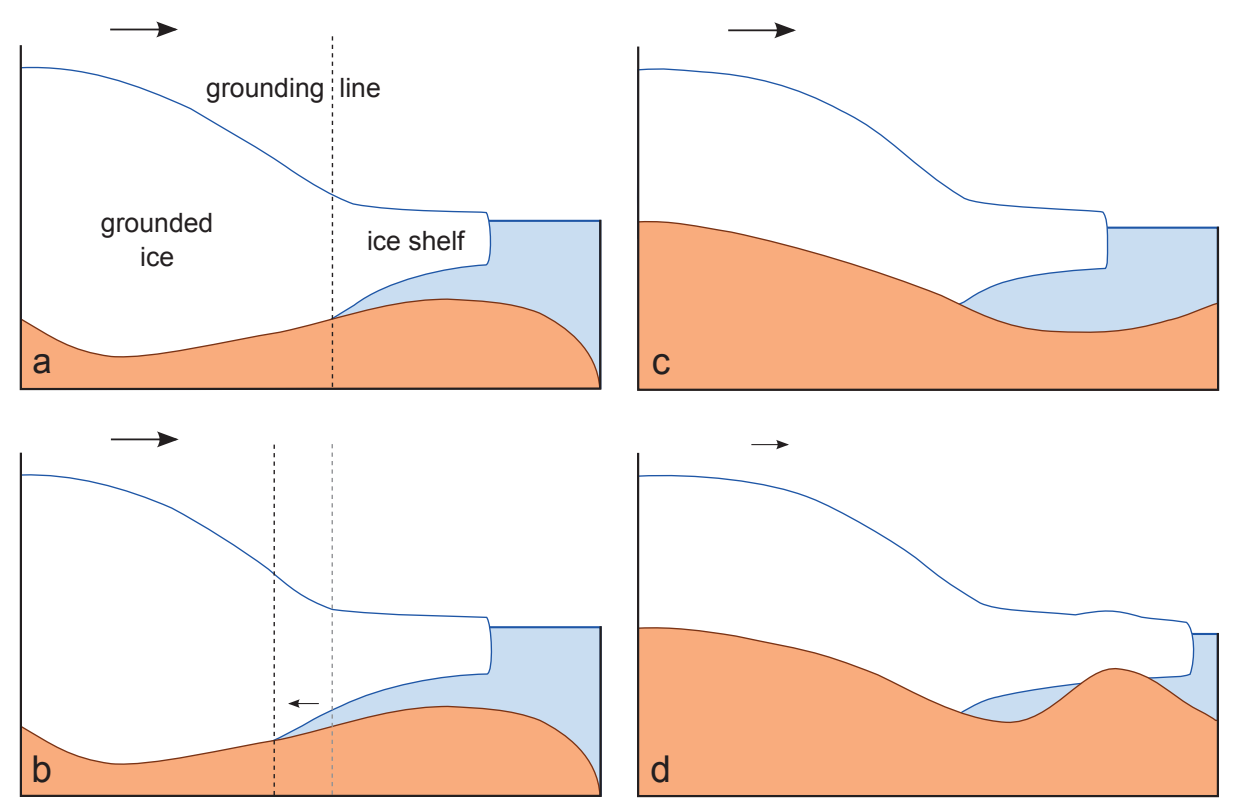

Figure 3: Simplified illustration of the marine ice sheet instability hypothesis. a) Unstable situation with the bedrock sloping down inland from the glacial front. b) The retreat of the grounding line (dashed line) onto a deeper bed leads to a positive feedback loop causing increased ice loss and further grounding line retreat. c) Stable situation with a reversed bed slope. d) Floating ice shelves slow down the flow of grounded ice, if there is contact between the ice shelf and the seabed or the coastline.

The Greenland ice sheet terminates largely on land and is not significantly affected by marine ice sheet instability. Ice from Greenland flows into the sea through outlet glaciers, which are better constrained by coastal topography than the ice streams of Antarctica (e.g. Pfeffer et al., 2008). While ice loss from Greenland is a major contributor to global sea level rise, the "fingerprint effect" reduces the contribution of Greenland close to zero in many northern locations such as the Baltic Sea (see Section 2.2.4). Therefore, the Antarctic ice sheet dominates the uncertainties of sea level rise projections in the Baltic Sea.

The modelling study of DeConto and Pollard (2016) concludes that Antarctica alone could contribute more than $1 \mathrm{~m}$ of sea level rise by 2100 and more than $15 \mathrm{~m}$ by 2500 . This would mean a significant upward revision of recent sea level projections. The model used by DeConto and Pollard (2016) couples ice sheet and climate dynamics and includes processes that have not been properly addressed in previous modelling studies, such as fracturing of the floating ice shelves and the collapse of vertical ice cliffs that are exposed when the ice shelves are lost. The ice cliff instability hypothesis is still under scientific debate, however (Edwards et al., 2019).

The rate of Antarctic ice sheet retreat is slower in other recent modelling studies. Golledge et al. (2015) project an Antarctic contribution of up to $39 \mathrm{~cm}$ by 2100, Ritz 

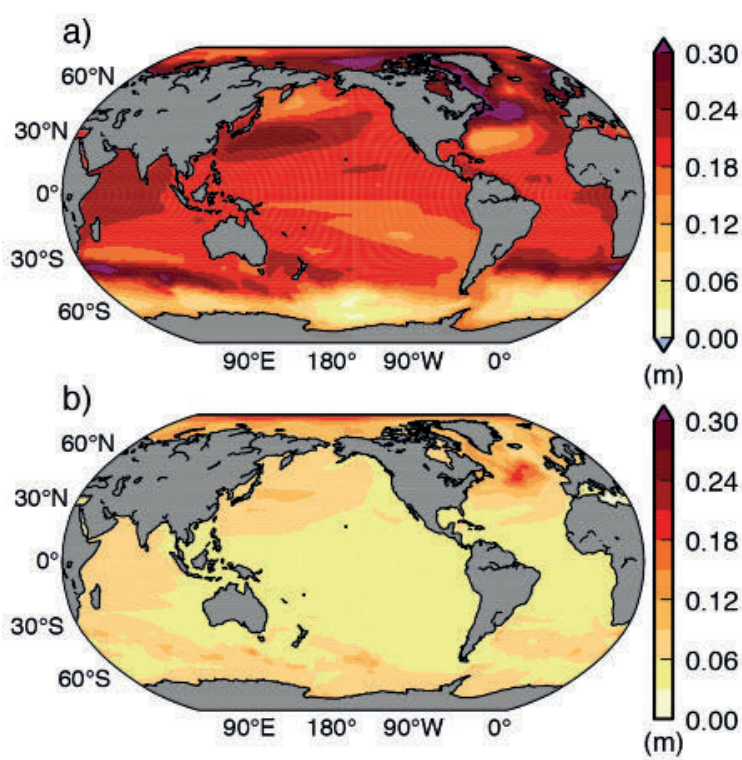

Figure 4: a) Ensemble mean projection of the time-averaged dynamic and steric sea level changes (m) for the period 2081-2100 relative to 1986-2005 based on the RCP4.5 scenario, computed from 21 CMIP5 climate models. The figure includes the globally averaged steric sea level increase of $0.18 \pm 0.05 \mathrm{~m}$. b) Rootmean-square deviation of the individual model results around the ensemble mean, characterizing the amount of variation between models. From Church et al. (2013a), their Fig. 13.16.

et al. (2015) one up to $30 \mathrm{~cm}$; the latter do not consider contributions larger than 50 $\mathrm{cm}$ realistic during this century. However, they emphasize that unless radical emission reductions are carried out, Antarctica is on the trajectory of significant and sustained retreat and will contribute several metres of sea level rise during the coming centuries. Winkelmann et al. (2015) calculate that the combustion of all available fossil fuel resources would result in Antarctica being nearly ice-free over time (several millennia).

\subsubsection{Regional deviations from the global mean}

Sea level rise is not uniform but has large geographical variation. Trends in sea surface height obtained from satellite altimetry over the period 1993-2012 (when the global mean sea level rose about $3 \mathrm{~mm} / \mathrm{yr}$ ) show areas of declining sea level as well as areas where the rate of sea level rise is over $10 \mathrm{~mm} / \mathrm{yr}$ (Church et al., 2013a). Changes in winds, ocean currents, the gravitational field of the Earth, atmospheric pressure, and other factors introduce regional anomalies that result in a complex pattern of absolute mean sea level change (sea level relative to the center of the Earth). When considering relative sea level change (sea level relative to land), regional differences in vertical land motion come into play, as well.

In the Arctic regions, the sea level rise caused by thermal expansion and dynamical changes in the oceans - changes in sea level induced by changes in winds, ocean currents, and ocean heat and freshwater content - is projected to be above average according to the climate models (Fig. 4). This higher-than-global sea level rise has been attributed to increasing freshwater content because of increased precipitation and river runoff (Landerer et al., 2007; Slangen et al., 2014). The CMIP5 (Coupled 


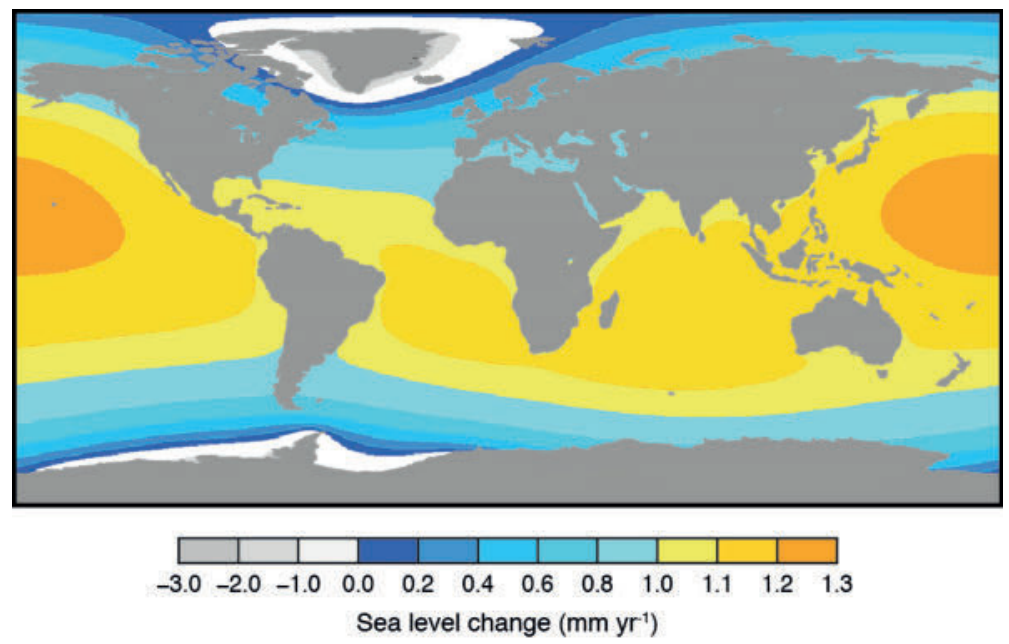

Figure 5: The combined "fingerprint" of the Greenland and West Antarctic ice sheets: modelled relative sea level change resulting from the melting of both ice sheets at a rate of $0.5 \mathrm{~mm} / \mathrm{yr}$ each (global mean rise 1 mm/yr). From Church et al. (2013a), their Fig. 2 in FAQ 13.1.

Model Intercomparison Project Phase 5) models give higher than average steric and dynamical sea level rise also in the Baltic Sea (Section 3.1.1). These results should be considered approximate, however, as global climate models are too coarse to simulate some important features of the Baltic Sea dynamics, such as the water exchange in the narrow Danish straits.

Melting glaciers and ice sheets also cause globally uneven patterns of sea level rise. This pattern is unique to each melting ice mass and is therefore called the "fingerprint" of the glacier or ice sheet (Fig. 5). Perhaps counterintuitively, the sea level rise is smaller in the vicinity of the melting ice mass and larger far from it (Mitrovica et al., 2001; Bamber and Riva, 2010; Mitrovica et al., 2011). This is because of the gravitational and crustal changes caused by the diminishing weight of the ice. The gravitational pull of the ice mass is weakened, which lowers the sea level near the melting glacier, and the crustal uplift that follows the diminishing weight also lowers the sea level. Close to the melting ice mass, the relative sea level actually declines as a result of these effects even though the meltwater raises the global sea level on average.

In the Baltic Sea, the melting of the Greenland ice sheet is far less important than the melting of the Antarctic ice sheet. In many simulations (Mitrovica et al., 2001; Tamisiea et al., 2003; Bamber and Riva, 2010), the zero line of the Greenland fingerprint runs through the Gulf of Bothnia, meaning that in the northern parts of the gulf the effect of Greenland melting on mean sea level is slightly negative and in the southern parts slightly positive. On the contrary, the sea level rise caused by the Antarctic ice sheet is expected to be slightly (ca. 10\%) above the global average everywhere in the Baltic Sea. Smaller mountain glaciers have varying effects because of their diverse 
geographical locations, but on average their combined effect is estimated to be below the global average in the Baltic Sea.

\subsection{The birth of a meteotsunami}

Meteotsunamis - meteorologically generated tsunami waves - are long waves caused by atmospheric disturbances (Defant, 1961; Rabinovich and Monserrat, 1996; Monserrat et al., 2006). They can reach destructive dimensions in extreme cases. One of the highest known events is the $6 \mathrm{~m}$ high meteotsunami that flooded the small Croatian town of Vela Luka on 21 June 1978 (Vilibić and Šepić, 2009). Among several fatal events are the nearly $5 \mathrm{~m}$ high meteotsunami that drowned three people in the Nagasaki Bay, Japan, on 31 March 1979 (Hibiya and Kajiura, 1982), and the up to $3 \mathrm{~m}$ high wave of Lake Michigan that swept fishermen off the piers and killed seven people in Chicago on 26 June 1954 (Bechle and Wu, 2014).

Fortunately, destructive meteotsunamis are rather rare. They only occur in shallow sea areas and big lakes where the wave can be amplified by the shape and bathymetry of the coast. The basic generation mechanism of a meteotsunami is presented in Figure 6 . The formation of a strong meteotsunami requires several coinciding factors:

1. An air pressure disturbance moving above a water body. These disturbances may be related to different atmospheric phenomena, such as weather fronts, thunderstorms, cyclones, hurricanes, squall lines, and atmospheric gravity waves.

2. Air-sea interaction: if the disturbance propagates at the same speed as the wave that it generates on the sea surface, there is continuous energy transfer from the atmosphere to the water wave.

3. Further amplification of the wave due to coastal bathymetry. Shoaling occurs when the wave enters shallower water: its speed decreases and height increases. Refraction can converge wave energy at certain places and increase the wave height. Harbour resonance can amplify the height of the waves entering semienclosed basins.

Because coastal bathymetry and geometry play a significant role in the amplification of the waves, there are hotspots of meteotsunami occurrence, with narrow and long bays being particularly vulnerable to destructive meteotsunamis. One such hotspot in the Mediterranean is the harbour of Ciutadella, Menorca, where several metres high oscillations - locally called rissaga - are regularly observed (Jansa et al., 2007). Indeed, nearly all known destructive meteotsunamis have occurred in bays or harbours and have not affected the nearby open coast (Monserrat et al., 2006). 


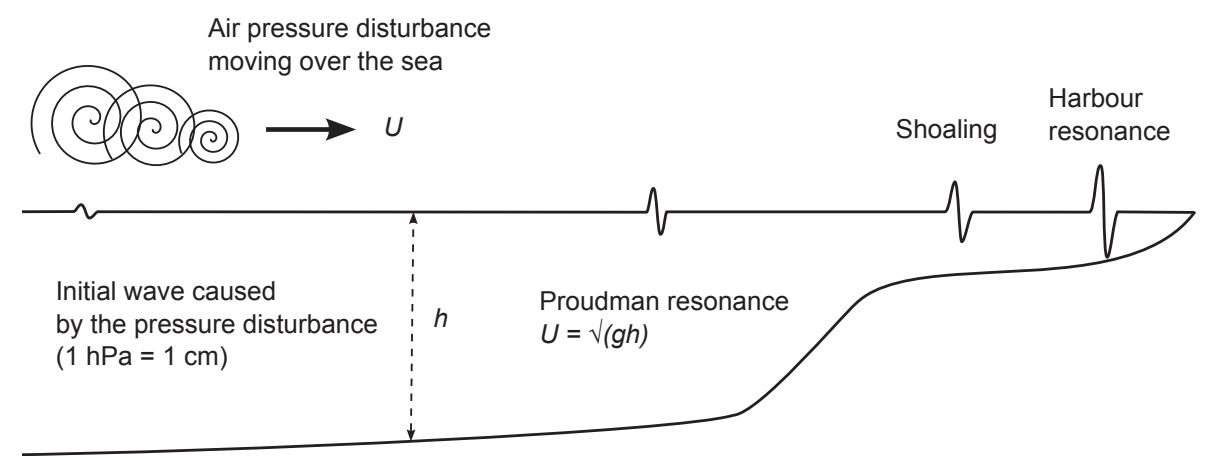

Figure 6: Sketch of the generation of a meteotsunami. The initially small wave is amplified through different resonance mechanisms as the wave approaches the coast.

\subsubsection{Resonance effects}

The air pressure disturbances creating meteotsunamis are steep but typically small, only a few hectopascals (hPa). These disturbances affect the sea level through the so-called inverted barometer effect: high pressure causes lower sea level and vice versa. Roughly, a $1 \mathrm{hPa}$ change in air pressure corresponds to a $1 \mathrm{~cm}$ change in sea level. Thus, an air pressure disturbance of a few hPas alone cannot produce significant waves. Rather, a meteotsunami is formed through resonance effects that amplify the initial wave of small amplitude. More crucial than the strength of the pressure disturbance are its propagation speed and direction as well as the bathymetry and shape of the coastline.

A shallow-water wave (also called a long wave) is one whose wavelength is much larger than the water depth. The phase velocity $\left(c_{p}\right)$ of such a wave depends only on water depth: $c_{p}=\sqrt{g h}$, where $h$ is water depth and $g$ is standard gravity. When the propagation velocity of an air pressure disturbance is close to that of the long wave, the disturbance continuously feeds the wave it generates. This is called the Proudman resonance (Proudman, 1929, 1953). The amplification is proportional to the fetch and to the spatial steepness of the disturbance (i.e. distance between the front and the disturbance maximum; Hibiya and Kajiura, 1982). Typical velocities of such air pressure disturbances are 20-40 m/s; thus the resonance occurs in ca. 40-160 m deep waters (Monserrat et al., 2006).

There are other resonance mechanisms as well that can transfer energy from an air pressure disturbance to the sea, such as the Greenspan resonance that occurs if the alongshore component of the disturbance velocity corresponds to the phase speed of edge waves (Greenspan, 1956; Monserrat et al., 2006). Edge waves are trapped waves that run along the shoreline. Shelf resonance occurs when the period or wavelength of the meteotsunami corresponds to the resonant period or wavelength of a continental shelf region (Monserrat et al., 2006). 
A meteotsunami approaching the coastline can be amplified by air-sea interactions, refraction-induced focusing, and shoaling, but the height of a meteotsunami is usually below $0.5 \mathrm{~m}$ on a straight coastline. Harbour resonance occurs when the frequency of the meteotsunami corresponds to the resonant frequency of a semi-enclosed basin (e.g. Rabinovich, 2009). When the arriving wave is repeatedly reflected at the boundaries of the basin, a standing wave can be created through the superposition of the waves travelling in opposite directions. Each bay or harbour has characteristic eigenfrequencies determined by its size and shape. If the meteotsunami has a significant amount of energy at the eigenfrequencies of the basin, the amplification of wave height can be catastrophic.

\subsubsection{Characteristics of meteotsunamis}

Giving an exact definition of what counts as a meteotsunami is not straightforward, as most sea level variations are of atmospheric origin. A meteotsunami is separated from other meteorologically generated wave phenomena by its dimensions, which are similar to other tsunami waves: periods of meteotsunamis range from a few minutes to two hours and wavelengths from one to hundreds of kilometres (Rabinovich, 2009). However, to stand out from other sea level variations the wave must have a notable height. One suggested height criterion is four times the standard deviation of sea level variations in a certain location (Monserrat et al., 2006).

A meteotsunami can consist of a single wave or several, and the whole event can have a relatively long duration, even a couple of days (Jansa et al., 2007). Favourable atmospheric conditions can generate multiple atmospheric disturbances that cause a sequence of meteotsunamis. For example, the meteotsunami event of 22-27 June 2014 was observed over a wide area from the western Mediterranean to the Black Sea, but strong oscillations were restricted to certain meteotsunami hotspots (Šepić et al., 2016).

Meteotsunamis have physical properties comparable to tsunamis generated by earthquakes, but unlike seismic tsunamis they cannot cause widespread damage. While a meteotsunami event is often observed in multiple locations along a coastline, high oscillations are restricted to individual bays, inlets or other hotspots where the arriving wave is amplified. Another difference compared to seismic tsunamis is that meteotsunamis are not created instantaneously but develop under external forcing.

In the scientific literature, also the term seiche has been used (e.g. Hibiya and Kajiura, 1982) before the term meteotsunami was established. Seiches are standing waves created in enclosed or partially enclosed water basins after the water body has been disturbed and starts to oscillate around the equilibrium. Meteotsunamis can acquire destructive dimensions when they create a standing wave in a semi-enclosed bay or harbour. However, seiches include all standing wave oscillations caused by any disturbance. In the Baltic Sea, seiche is a very typical phenomenon in the various sub-basins, large and small, and should not be confused with meteotsunamis. 


\section{Sea level projections for the Finnish coast}

In Papers I and III, regional sea level projections for the Finnish coast were calculated. The aim was to construct projections of mean sea level change over the $21^{\text {st }}$ century as location-specific probability distributions that cover the full probability range, take into account regional anomalies in sea level rise, and include all different scenarios of future greenhouse gas emissions. This objective was largely motivated by the demands of coastal planning: different types of infrastructure tolerate different risk levels, and a single probability distribution is more easily applicable in practical decision-making than a set of different scenarios.

In Paper III, the probability distribution of mean sea level change was further combined with the probability distribution of short-term sea level variations to yield probabilities of future flooding on the Finnish coast. These results were used to set national recommendations for minimum building elevations, targeting the sea level that will be exceeded at most once in the next 200 years, i.e. during the potential lifetime of new buildings (Kahma et al., 2014). In addition to coastal planning, the results have been utilized in flood risk mapping of the Finnish coastline. The basic elements of the methodology - combining the probability distribution characterizing uncertainty in future mean sea level with the observed distribution of short-term variations, as a sum of independent random variables - were used in the Finnish Institute of Marine Research already in 1998 when the previous recommendations for building elevations were given (Kahma et al., 1998), and even before in 1990 in a safety assessment made for a Finnish nuclear power station (Kimmo Kahma, pers. comm.).

Our probability distributions of regional mean sea level change are based on an ensemble of global sea level rise projections. This approach was chosen because of the problems of sea level projections described in Section 2.2.2: uncertainties are large, different methods yield different results, and only a few projections give full probability distributions. As Kopp et al. (2017) and Garner et al. (2018) point out, there is no single method at the moment that could be considered best for estimating future sea level rise at different probability levels, and it is wise to compare different distributions and adopt flexible management frameworks to cope with the uncertainty. The scientific uncertainty also means that the projections inevitably contain some degree of subjective choices, approximations and assumptions. By drawing from an ensemble of projections we hope to include all potential sources of sea level rise, even the low-probability, high-risk ones such as the disintegration of the West Antarctic ice sheet (Section 2.2.3). The method and results obtained from these studies are summarized below. 


\subsection{Main components of long-term sea level change}

The change in mean sea level $h_{m}$ at a location $i$ on the Finnish coast can be expressed as the sum of the following components:

$$
h_{m}(t, i)=h_{l}(t, i)-u(i) t+w(t, i)+\epsilon(t, i)
$$

where $t$ is the time since the reference year, $h_{l}$ is the large-scale sea level rise, or the regional manifestation of global sea level changes, $u$ is the rate of postglacial land uplift, assumed to proceed linearly on the time scales considered, $w$ represents the local wind-induced component related to the volume and distribution of water within the Baltic Sea, and $\epsilon$ incorporates residual variations. The observed annual mean sea levels on the Finnish coast over the $20^{\text {th }}$ century can be fairly accurately reproduced by calculating the sum of the three main components: $h_{l}, u$, and $w$ (Fig. 4 in Paper I).

This three-component model was used in both Papers I and III. To obtain probabilistic projections of future mean sea level change, we need to make projections of each of the three components and combine them as probability distributions.

\subsubsection{Adapting global projections to the Finnish coast}

The ensemble of sea level rise projections used to calculate the regional projections is presented in Table 1. The ensemble in Paper I included 10 members, in Paper III newer projections were included and the IPCC's Fourth Assessment Report (2007) was replaced by the Fifth (2013) to yield a total number of 14 projections.

Global sea level rise is not uniform for many reasons (Section 2.2.4). To take into account regional deviations from the global mean, the global projections published in the literature were adjusted for regional effects. Different projections were calculated for three different sea areas along the Finnish coast: the Gulf of Finland, the Bothnian Sea (southern part of the Gulf of Bothnia), and the Bothnian Bay (northern part; Fig. 1). Glacier and ice sheet contributions were scaled with fingerprint coefficients based on the results of Mitrovica et al. (2001). The contribution of the Greenland ice sheet is expected to be small on the Finnish coast: zero in the Bothnian Bay, $5 \%$ of the global average in the Bothnian Sea, and $15 \%$ in the Gulf of Finland. The effect of small glaciers and ice caps is also below the global average in Finland, 50-65\% depending on location. For the Antarctic ice sheet, a slightly larger rise (105\%) compared to the global mean is expected everywhere along the Finnish coastline.

Climate model simulations give an above average thermal expansion and ocean dynamics component in the North Sea-Baltic Sea region (Church et al., 2013a; Slangen et al., 2014). This was taken into account by replacing the global estimates with regional ones. In Paper III, this was done more elaborately than in Paper I by analyzing results from 21 CMIP5 atmosphere-ocean general circulation models. Global climate models are not accurate enough to estimate variations within the Baltic Sea, and regional differences are small compared to uncertainties, so the mean over the whole 


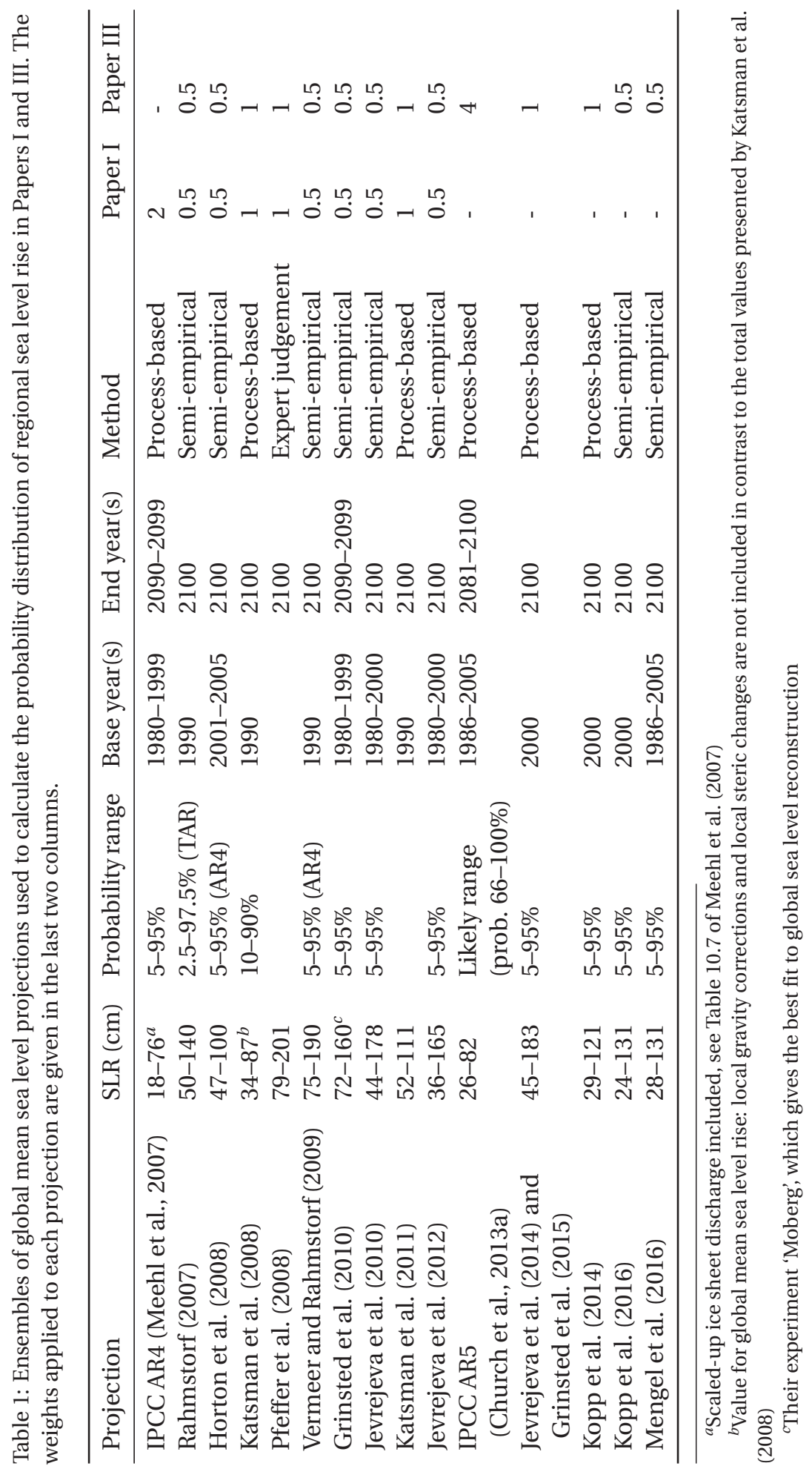


Finnish coast was calculated. For example in the scenario RCP8.5, the pathway of highest carbon emissions, the regional sea level rise caused by thermal expansion and ocean dynamics was $43 \mathrm{~cm}(27-60 \mathrm{~cm})$ in 2081-2100 compared to 1986-2005 (5-95\% uncertainty range). The corresponding global mean value from Church et al. (2013a) is $27 \mathrm{~cm}(21-33 \mathrm{~cm})$.

Most semi-empirical projections cannot attribute the projected sea level rise to different sources, as they simply model total sea level rise based on the observed relation between global mean sea level and some other climate variable. These projections were adapted to the Finnish coast using a simple scaling approach, based on the relationship between regional and global sea level rise in the projections where component-wise regionalisation was possible, as described above (Fig. 5 in Paper I and Fig. 2 in Paper III).

After the regionalisation, we fitted Weibull distributions to the individual members of the ensemble (normalized to the time span 2000-2100) and combined them as a mixture distribution to yield the final sea level rise distribution. The projections were given different weights in the mixture (Table 1). Semi-empirical projections were given a lower weight to compensate for their large number in the ensemble and because of lower confidence in these models (Church et al., 2013a). IPCC projections were given a larger weight because they represent the most comprehensive assessments drawing from a wide body of research. The effect of weighting was assessed in both Papers I and III and it was concluded that the method is not very sensitive to the subjective choice of weights. Weighting lowers the results by ca. 5-10 cm compared to the projection where all members of the ensemble are included with similar weights in the mixture.

The resulting 5-95\% probability ranges of mean sea level rise in 2000-2100 are shown in Table 2 globally and for the three sea areas on the Finnish coast (for full probability distributions, see Fig. 6 in Paper I and Fig. 5b in Paper III). The results obtained in Papers I and III were very similar despite differences in the projection ensemble and details of the regionalisation. According to the results, the effect of large-scale sea level rise on the Finnish coast will be approximately $80 \%$ of the global mean - slightly less in the Gulf of Bothnia and slightly more in the Gulf of Finland. Thus, the larger-than-average thermal expansion contribution is more than compensated by the smaller-than-average glacier and ice sheet contributions.

\subsubsection{Changes in wind climate}

As was noted in Section 2.1, sea level variations in the Baltic Sea are mostly regulated by atmospheric conditions in the region, both in the short term and in annual and decadal time spans. Interannual variations in mean sea level on the Finnish coast are of the order of $20 \mathrm{~cm}$, and mean sea level is positively correlated with the North Atlantic Oscillation (NAO) index that describes large-scale atmospheric conditions in the region - a correlation that is seen also on other Baltic coasts (e.g. Andersson, 2002; Suursaar and Sooäär, 2007). A positive NAO index is connected to strong westerly 
Table 2: Large-scale sea level rise in 2000-2100 (5-95\% probability ranges) globally and in the three sea areas along the Finnish coast, according to the probability distributions calculated in Papers I and III. Note that these results do not include postglacial land uplift and local wind-induced effects.

\begin{tabular}{lll}
\hline & Paper I & Paper III \\
\hline Global & $26-155 \mathrm{~cm}$ & $31-155 \mathrm{~cm}$ \\
Gulf of Finland & $24-124 \mathrm{~cm}$ & $24-126 \mathrm{~cm}$ \\
Bothnian Sea & $23-120 \mathrm{~cm}$ & $24-122 \mathrm{~cm}$ \\
Bothnian Bay & $21-114 \mathrm{~cm}$ & $24-115 \mathrm{~cm}$ \\
\hline
\end{tabular}

winds over the North Atlantic, which push water through the Danish straits and pile it up in the northeastern parts of the Baltic Sea. Variability in the NAO index explains $37-46 \%$ of the interannual variation of mean sea level on the Finnish coast, depending on location (Johansson et al., 2003).

In Paper I, even better correlations were found between zonal geostrophic wind and annual mean sea level on the Finnish coast. The best correlation was found with detrended zonal geostrophic wind $\left(U_{g}\right)$ near the entrance of the Baltic Sea, on the island of Bornholm at $55^{\circ} \mathrm{N}, 15^{\circ} \mathrm{E}$ (Fig. 1). Changes in zonal geostrophic wind explain $84-89 \%$ of the interannual variations in mean sea level. The relationship between $U_{g}$ at Bornholm and the sea level on the Finnish coast, calculated from the $20^{\text {th }}$ century observations, was assumed to remain unchanged in the future. Climate model projections of $U_{g}$ could then be used to estimate the effect of changes in the wind climate on future mean sea level in Finland ( $w$ in Eq. 3.1).

While projections of future $U_{g}$ are subject to large uncertainties, on average climate models project an increase in the zonal geostrophic wind in the southern Baltic Sea. This was estimated in Paper I to lead to a small additional sea level rise on the Finnish coast: on average, 6-7 $\mathrm{cm}$ by 2081-2100 compared to the reference level 1961-2000, with values ranging from a $3-4 \mathrm{~cm}$ decrease to a $15-19 \mathrm{~cm}$ increase depending on the model and emission scenario. The spread between different model projections was larger than the differences between emission scenarios. These results were also utilized in Paper III to estimate the wind-induced mean sea level component.

\subsubsection{Land uplift}

Land uplift rates were calculated from the $20^{\text {th }}$ century observations of annual mean sea level from the Finnish tide gauges. Referring to Eq. 3.1, we first removed the observed annual means of the wind-induced component $w$ from the observed annual mean sea levels $h_{m}$. The trend in the resulting time series is a combination of the land uplift rate $u$ and the trend in the large-scale sea level rise $h_{l}$, which we replaced with the observed $20^{\text {th }}$ century rate of global mean sea level rise-assuming that sea level rise has proceeded linearly. The land uplift rates thus obtained range from $4.05 \pm 0.75 \mathrm{~mm} / \mathrm{yr}$ 
in Hamina, in the easternmost part of the Gulf of Finland, to $9.85 \pm 0.69 \mathrm{~mm} / \mathrm{yr}$ in Vaasa (Table 3 in Paper I).

Removing the wind-induced component from the observed annual means before calculating trends improves the accuracy of land uplift estimates compared with older analyses (e.g. Lisitzin, 1964; Vermeer et al., 1988; Johansson et al., 2003), as the windinduced component has a positive trend over the $20^{\text {th }}$ century and it also introduces large interannual variations in mean sea level. The weakness of this analysis is the lack of exact information on the rate of large-scale sea level rise in the Baltic Sea over the $20^{\text {th }}$ century, which is approximated using the global mean value.

Compared with recently published independent land uplift estimates obtained from geodetic observations and modelling (Vestøl et al., 2019), our land uplift rates are ca. $1 \mathrm{~mm} / \mathrm{yr}$ higher, with roughly similar error estimates. Some of this difference may be explained by the possible overestimation of the large-scale sea level rise in our analysis (approximated with the global mean rate of $1.7 \mathrm{~mm} / \mathrm{yr}$ from Church et al., 2013a), which would lead to an overestimation in the land uplift rates, too. Recent studies have revised the estimated rate of $20^{\text {th }}$ century sea level rise downward, for example Hay et al. (2015) suggest $1.2 \mathrm{~mm} / \mathrm{yr}$, Dangendorf et al. (2017) $1.1 \mathrm{~mm} / \mathrm{yr}$, and Oppenheimer et al. (2019) $1.4 \mathrm{~mm} / \mathrm{yr}$.

\subsection{Future change in mean sea level in Finland}

The probability distributions of the three components, the regional sea level rise $h_{l}$, wind-induced changes $w$ and land uplift $u$, were combined as independent random variables to yield probability distributions of mean sea level change. This calculation was performed for all 13 tide gauges on the Finnish coast. Projected changes in mean sea level on the Finnish coast are presented in Table 3, according to the results of Papers I and III. Despite some methodological updates in Paper III compared to Paper I, such as the updated ensemble of sea level rise projections (Table 1), the differences in projections are small, only a few centimetres. Figure 7 shows the historical mean sea level decline together with projections of future mean sea level change for three coastal cities in Finland based on the results in Paper III.

According to the average scenario, mean sea level decline will continue in the Gulf of Bothnia until the end of the century, while sea level rise of up to $33 \mathrm{~cm}$ is expected in the Gulf of Finland. Low scenarios yield declining sea levels everywhere on the Finnish coastline, while high scenarios would cause a rise ranging from $21 \mathrm{~cm}$ in Vaasa to $90 \mathrm{~cm}$ in Hamina. Thus, the highest sea level rise is projected in the Gulf of Finland, where the rates of land uplift are smallest and also the regional sea level rise is slightly higher.

These results are reflected in the flood probability distributions calculated in $\mathrm{Pa}$ per III. The mean sea level projections were combined with distributions of short-term sea level variations, assuming that the short-term and long-term variations are independent and their combination is the sum of these two random variables. From 


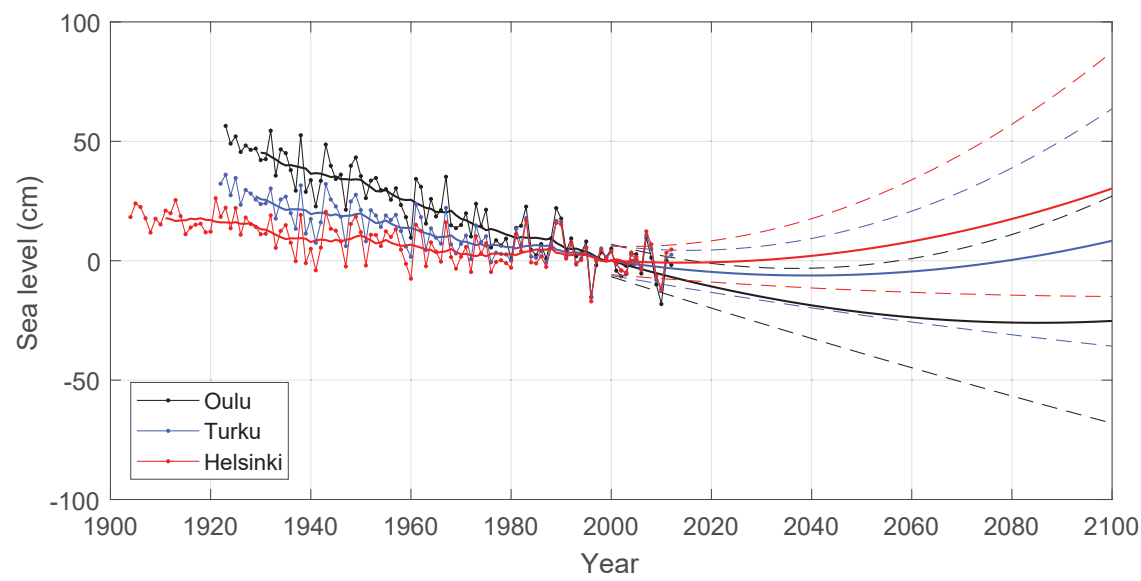

Figure 7: Observed annual mean sea levels (with the 15-year moving average) and scenarios for future mean sea level change relative to the year 2000 in some of the largest coastal cities of Finland: Oulu, Turku, and Helsinki (for locations, see Fig. 1). Solid lines 2000-2100 show the average scenario, dashed lines are the low and high scenarios corresponding to the $5^{\text {th }}$ and $95^{\text {th }}$ percentiles of the probability distribution.

the resulting flood probability distributions (Fig. 7 in Paper III), future sea levels with certain exceedance frequencies can be determined (Table 4 in Paper III). According to the results, flood probabilities will considerably increase in the Gulf of Finland. For example, the highest coastal flood on record created by the storm Gudrun in January 2005 is estimated to occur 3 times per century in the current climate, but every second year on average at the end of the century. Thus, rare floods of today would become commonplace by 2100 in the Gulf of Finland. In the Bothnian Sea and the Bothnian Bay, flooding risks will continue to diminish during the next decades but rise back to the present level or slightly above them in the Bothnian Bay and clearly above the present level in the Bothnian Sea by 2100 . 
Table 3: Change in mean sea level (cm) in 2000-2100 at the Finnish tide gauges, according to the projections of Papers I and III. The average scenario is the weighted average of the probability distribution, low and high scenarios correspond to the $5^{\text {th }}$ and $95^{\text {th }}$ percentiles, respectively.

\begin{tabular}{|c|c|c|c|c|c|c|}
\hline \multirow[t]{2}{*}{ Tide gauge } & \multicolumn{3}{|c|}{ Paper I } & \multicolumn{3}{|c|}{ Paper III } \\
\hline & Low & Average & High & Low & Average & High \\
\hline Kemi & -69 & -26 & 25 & -71 & -28 & 24 \\
\hline Oulu & -66 & -24 & 28 & -69 & -25 & 27 \\
\hline Raahe & -69 & -27 & 25 & -71 & -28 & 24 \\
\hline Pietarsaari & -70 & -28 & 24 & -72 & -29 & 23 \\
\hline Vaasa & -72 & -30 & 22 & -74 & -31 & 21 \\
\hline Kaskinen & -66 & -21 & 35 & -66 & -22 & 33 \\
\hline Mäntyluoto & -57 & -13 & 43 & -58 & -13 & 42 \\
\hline Rauma & -49 & -4 & 52 & -50 & -5 & 50 \\
\hline Turku & -36 & 9 & 65 & -36 & 8 & 63 \\
\hline Föglö & -38 & 6 & 62 & -39 & 6 & 61 \\
\hline Hanko & -22 & 24 & 82 & -22 & 24 & 80 \\
\hline Helsinki & -15 & 30 & 89 & -15 & 30 & 87 \\
\hline Hamina & -12 & 33 & 92 & -13 & 33 & 90 \\
\hline
\end{tabular}




\section{Meteotsunamis in the Baltic Sea}

The coasts of the Baltic Sea know many stories of rare, exceptionally high waves. The reports of these events have common characteristics: sudden high waves that come seemingly out of nowhere and disappear as quickly as they appeared; they can occur in clear and calm weather as well as during storms (Doss, 1906). These waves have been called Seebär on the German-speaking southern Baltic coast (lit. "sea wave", from old German Bahre, "wave") and sjösprång (lit. "sea leap") in the Swedish-speaking coastal regions of Sweden and Finland.

Almost a century ago, Finnish geophysicist Henrik Renqvist described the sjösprång phenomenon like this:

Sometimes, when the sea is calm, the weather is still, and the isobar maps do not show any peculiarities, the water will suddenly rise with great speed only to soon fall again just as quickly. The phenomenon can be repeated once, twice, or many times. The amplitude between high and low water can be a few decimetres, or a metre, two metres, perhaps more. The interval between two high-water waves can be half a minute, two minutes, a quarter-hour, or an hour. Half an hour after the onset of the phenomenon, the surface can be as calm as before; in other cases, a strange restlessness is seen for several hours. Often, the weather changes shortly after the jump in sea level, in other cases no immediate change is seen.

I want to emphasize that the phenomenon does not occur only when the sea is calm and the weather still, it can just as well be a rough sea with storm, thunder and a pressure nose on the barogram. I have said what I have said in order to make it understandable that the phenomenon is a natural wonder in the eyes of the coastal dweller and a complex problem for science. (Renqvist, 1926b, translated from Swedish)

The descriptions of these events leave little doubt that the mysterious waves are meteotsunamis. The mean depth of the Baltic Sea, $54 \mathrm{~m}$, corresponds to a long wave speed of $23 \mathrm{~m} / \mathrm{s}$. Thus, it is a favourable area for meteotsunami generation through Proudman resonance or other resonance effects (Section 2.3.1). Figure 8 shows the bathymetry of the Baltic Sea converted to long wave speed; atmospheric disturbances moving over the sea close to this speed can activate Proudman resonance and generate meteotsunamis. The exact amplification mechanisms of meteotsunamis observed in the Baltic Sea are largely unknown, however.

Despite the work by Renqvist (1926a,b), who documented a meteotsunami in Finland on 15 May 1924, the existence of the phenomenon had been forgotten among Finnish sea level researchers and the eyewitness reports of such events in 2010 came as a surprise. No such reports had been received since at least the beginning of the 
1970s (Kimmo Kahma, pers. comm.). Likewise, the Seebär phenomenon is mentioned several times in older scientific literature (e.g. Credner, 1889; Doss, 1906; Meissner, 1924; Defant, 1961) but modern analyses of Baltic meteotsunamis are lacking. Below, I attempt to draw a picture of meteotsunami occurrence in the Baltic Sea based on old literature and the results obtained in Papers II and IV.

\subsection{Historical events in the Baltic Sea}

\subsubsection{Seebär in the southern Baltic Sea}

Doss (1906) lists 25 Seebär events from the southern and southeastern Baltic coasts from the mid- $18^{\text {th }}$ century to the end of the $19^{\text {th }}$ century, and one possible event in 1696 in Tallinn, Estonia. Most of these events occurred on the coasts of Mecklenburg and Pomerania (present-day German and Polish coasts), but several events are reported also from Liepāja (Latvia) and Pärnu (Estonia), and one from Kranz, currently Zelenogradsk (Kaliningrad).

A notable meteotsunami was observed on the northern coast of the island of Hiiumaa (Estonia) on 15 January 1858. A detailed description of the event was given by August Briancourt, master dyer at the Kertel (Kärdla) cloth factory. The first wave came at 2:10 pm and the water level in the small river flowing into the sea rose $0.9 \mathrm{~m}$, returning to normal 9 minutes later. The second wave at 2:26 pm was even higher $(1.05 \mathrm{~m})$ and water fell back to the normal level 15 minutes later. The phenomenon was observed also in the nearby harbours of Tiefenhafen (Suursadam) and Hohenholm (Kõrgessaare). The weather was stormy, with strong winds from SW in the morning, showers of snow, hail, and freezing rain. Doss (1906) furthermore notes that thunder was observed on the same day in Stockholm and Uppsala (Sweden), which is very rare at that time of the year.

Among the scholars of that time, two competing theories were presented to explain the origin of these waves: seismic and meteorological (Doss, 1906). Some believed that the Hiiumaa waves were connected to the earthquake that occurred only 6 hours later in Žilina, Slovakia. Others noted that the waves were observed on the opposite (northern) side of the island and occurred before the earthquake, and no trembling of the earth was noticed in Hiiumaa. The meteorological origin was supported by the fact that the waves seemed to coincide with unusual atmospheric phenomena pressure jumps, wind shift, storm, thunder. Some referred to the seiche phenomenon, which was known to occur in Lake Geneva and also in the Baltic Sea in connection with sudden strong storms and rapid changes in air pressure. Doss (1906) himself was convinced that the Seebär waves are of meteorological origin, and that earthquakegenerated waves should not be counted as Seebär. A meteorological cause is also pointed out by Meissner (1924) in connection with Seebär events observed in Stolpmünde (currently Ustka, Poland) in 1921 and 1922. 


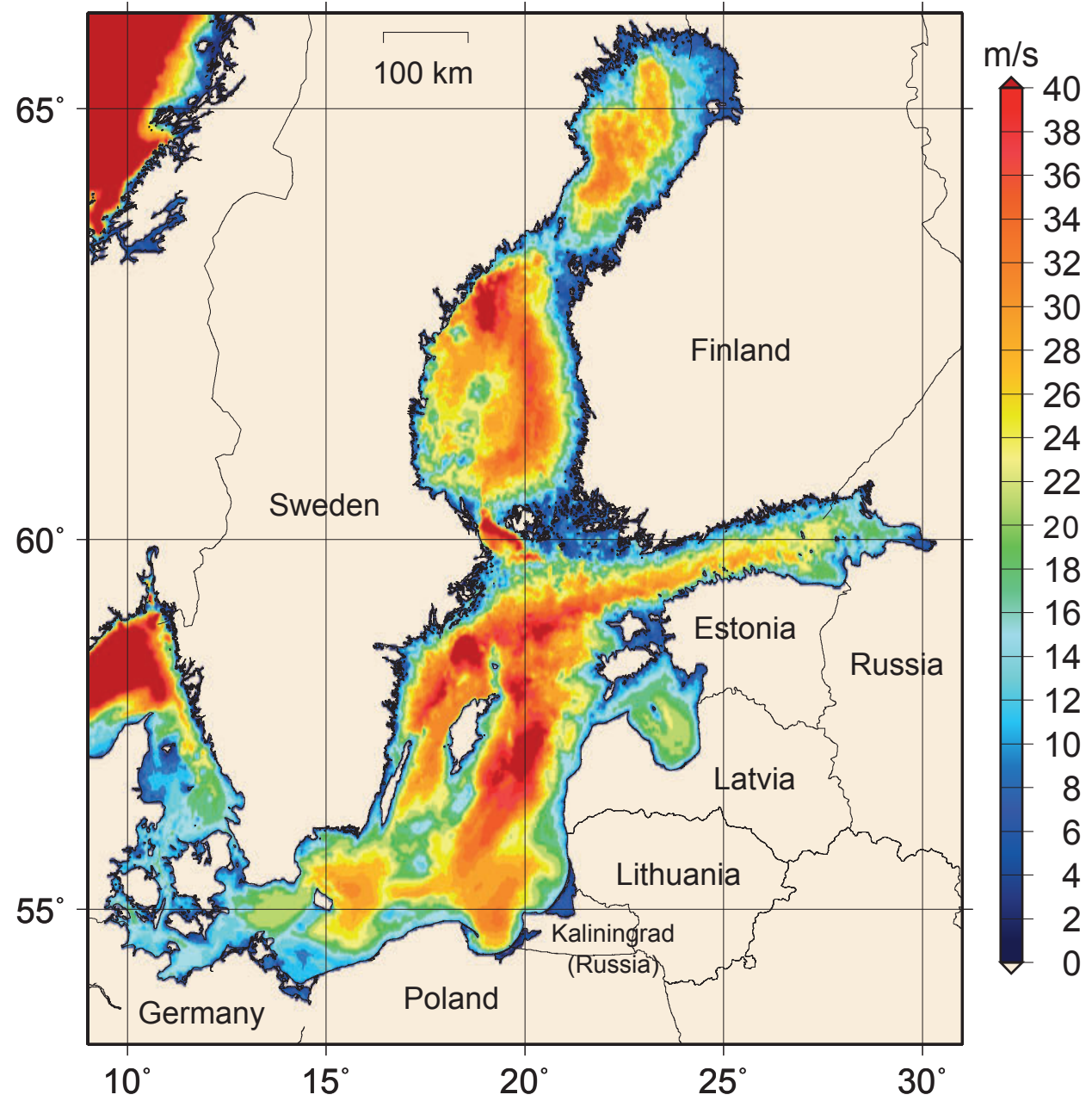

Figure 8: Bathymetric map of the Baltic Sea, with depths converted to long wave speed in the sea according to $\sqrt{g h}$, where $g$ is acceleration due to gravity and $h$ is water depth. Bathymetry data is from the IOWTOPO2 dataset (Seifert et al., 2001) with a spatial resolution of 1' $\times 2$ ' (ca. $2 \mathrm{~km})$. 
Doss (1906) furthermore correctly believed that the shape of the coastline affects the height of the waves, because standing waves can be formed and the waves amplified through interference. Waves entering river mouths can form a bore, which might explain the unusual height (up to $3 \mathrm{~m}$ ) of the Seebär observed in Pärnu. The bridge in the Pärnu river was damaged by these waves in 1841 and 1845, and in 1836, two of the four horses that were on the bridge were lost to the sudden flood, while their owners managed to save themselves (Doss, 1906).

The events in Liepāja (Latvia) in 1825, 1845, 1858, and 1893 were also on some occasions strong enough to cause hazardous situations. In July 1845, the sea level rose so rapidly that people in the beach huts suddenly found themselves in 3-4 feet deep water (Doss, 1906). According to the newspaper accounts, no one was injured, but some bathers lost their clothes and the beach huts were dislocated. The event was over in a quarter of an hour. A waterspout was observed; however, Doss (1906) notes that a waterspout alone could not cause the sea level variations that were observed on a stretch of coast several miles wide.

The oldest known Seebär events come from the coasts of Pomerania in the southern Baltic Sea. A strong storm and a destructive flood severely damaged coastal towns along nearly the entire southern Baltic coast from Wismar to Kaliningrad in September 1497 (Piotrowski et al., 2017). In Darłowo (Rügenwalde), according to the chronicle of the local monastery, the storm threw several ships on dry land and carried one of them more than $3 \mathrm{~km}$ inland up to the hill where the Church of St. Gertrude is located. Anrdzej Piotrowski from the Polish Geological Institute has estimated that the flood height was at least $3 \mathrm{~m}$ and, if the story of the ship holds true, it could have been much higher (Piotrowski, 2007). A meteotsunami on top of the storm surge may have contributed to the extreme height of the flood.

In April 1757, near Trzebiatów (Treptow), three successive high waves reportedly snatched an anchored ship from the harbour and moved it far onto the land:

The Baltic Sea often holds its own weather, which has no connection with weather on the land; sometimes, only rarely however, a submarine storm occurs in the Baltic Sea, which one can assume because under a clear and calm sky, a thunder can be heard rolling along the Pomeranian coast, and dead or half-dead marine or coastal fishes are thrown out on the land. That happened for instance on the 3rd of April, 1757: about the noon, at a calm and bright weather, the Baltic coast near Trzebiatów on Rega river became suddenly rolling so much that a big ferry-boat, moored in the harbour, was snatched away by high waves and shifted far on the land. After that (rolling) had been repeated three times, the sea became calm again. Local sailors call this phenomenon "Seebär". (L. W. Brüggemann, 1779, according to Piotrowski, 2007)

Piotrowski et al. (2017) attempted to find geological traces of the Seebär events on the coastal plain near the mouth of river Rega. They found a prominent (thickness 0.5$50 \mathrm{~cm}$ ) and widespread sandy layer, which the authors interpret based on radiocarbon 
datings to be a deposit of the 1497 storm surge. A second, thinner and less extensive sandy layer from the $18^{\text {th }}$ century might be related to the Seebär event in 1757 , but the authors consider it more likely to be left by a storm surge that has caused breaching of the sand dunes and inundation of the coastal plain.

\subsubsection{Historical events in Finland}

The shallow waters and broken topography of the Finnish coast are favourable for meteotsunami formation when conditions fall in place. One such event in 1876 on the Gulf of Finland was witnessed by linguist Herman Vendell. In a newspaper article, he describes a sailing trip in Kantvik (Kirkkonummi):

It was Seven Sleepers' Day, 27 July 1876. [...] As the sky was cloudless, the weather mild, and the breeze suitably brisk in the morning, I set out to sail on the open sea. Under a south-westerly wind and with full sails it was a pleasure to cut the crests of the smoothly rounded waves. The bow was already pointing homewards, when the wind calmed and, looking behind me, I saw, far out in the Gulf of Finland a dark-blue horizon appearing and heard a rumbling like distant thunder. Having made it back to the boathouse I was caught by a suddenly onrushing remarkably high wave, followed by a whistling storm. In a hurry the boat was secured and the sails furled. But the flood and storm was so fierce that before my companion and I had left the shaking boathouse, the pier was torn away into shreds, and we had to wade in water up to our armpits to the shore. The water rose by some 4 or 5 feet above normal level and carried planks, lumber, and vessels far up onto a meadow [...]. This was followed by the full raging of the forces of nature, which during the evening and the night escalated into an unusually powerful thunder, punctuated by bright bursts of light, and quickly strobing bolts of lightning.

Such natural phenomena are called "sjösprång" in this area. They repeated quite often during the same summer, though to a smaller degree and always during a south-westerly wind. (H. Vendell: Något om sjösprång. Folkvännen 1885, nos. 133 and 134. Translated from Swedish.)

On the evening of 15 May 1924, a strong meteotsunami was observed on the southern Finnish coast. Newspapers reported of unusual rising and falling of the sea level that was repeated several times with short intervals, lifting up old tree trunks from the bottom and revealing long stretches of seafloor in shallow places during the outflow (Renqvist, 1926b). Observations of the phenomenon were reported from more than 20 locations, mostly in the Archipelago Sea and western Gulf of Finland. The waves occurred in the evening between 6 and $9 \mathrm{pm}$, generally earlier in the west than in the east. However, in Utö and Bågaskär sea level oscillations were observed already between 2 and $6 \mathrm{pm}$. 
The event was studied in detail by Renqvist (1926a,b). The meteotsunami was not observed in Estonia on the opposite side of the Gulf of Finland. The maximum height of the observed waves was $1.2 \mathrm{~m}$ in western Gulf of Finland east of Hanko, but in most places the height was around $0.5 \mathrm{~m}$. At the tide gauges of Hanko and Helsinki, only damped oscillations of small amplitude were registered. According to the eyewitness observations, the period of a single wave was 5-15 min and the event was typically over within an hour. It seems that the anomalous observations in Utö and Bågaskär were related to somewhat longer waves.

In the afternoon of 15 May 1924, a mild wind was blowing from the south or southwest and there was a strong east-west temperature gradient over the Baltic Sea: in Stockholm the temperature was 18 degrees, in Hanko only 6. During the evening, mild wind, dark clouds, thunder, wind gusts, and fog were reported from many observation sites, and small jumps in air pressure were registered at meteorological stations in the region. Renqvist $(1926 a, b)$ notes that the Seebär phenomenon has in earlier literature been connected to thunder and rapid variations in air pressure. However, as electrical forces cannot cause sea level variations and changes in air pressure by themselves cannot explain such high waves, Renqvist was led to seek the explanation from whirlwinds and tornadoes, even though no such phenomena were observed by the eyewitnesses.

\subsection{Recent events}

\subsubsection{Recent meteotsunamis in Finland}

In the summers of 2010 and 2011, the Finnish Meteorological Institute received several messages from citizens who had witnessed exceptional sea level events on the Finnish coast. The eyewitnesses reported strange waves with a period ranging from a few minutes to fifteen minutes and height from 30 to $100 \mathrm{~cm}$. Weather conditions were described as not showing anything out of the ordinary. In Paper II, these observations were documented and the events examined using sea level and meteorological data. Tide gauge observations confirmed the eyewitness observations, but the oscillations recorded at the measurement sites had generally a much smaller height. The oscillations coincided with small (1-4 hPa) sudden jumps in surface air pressure at coastal observation stations (Figs. 3, 6, 9, and 12 in Paper II).

The propagation speed of the atmospheric disturbances was estimated from radar imagery. Both events observed in the Gulf of Finland, on 29 July 2010 and 8 August 2010 , were caused by an air pressure disturbance propagating northwards across the gulf from Estonia; speeds were 22-24 m/s, corresponding to the long wave speed in 49-58 $\mathrm{m}$ deep water. While the speed of the disturbances matched long wave speed in parts of the gulf (Fig. 8), in Paper II it was concluded that the amplification due to Proudman resonance alone was not that significant because of the relatively small width of the gulf $(80 \mathrm{~km})$ and the concave bottom topography. In that case, effects 
controlled by local bathymetry must have dominated to create the up to $1 \mathrm{~m}$ high waves observed by eyewitnesses. The small height, $10-15 \mathrm{~cm}$, of the waves recorded at the tide gauges also points to this conclusion.

Also on 8 August 2010, a squall line propagated northward along the coast of the Gulf of Bothnia, creating a small meteotsunami observed in Raahe. The speed was $18 \mathrm{~m} / \mathrm{s}$, corresponding to the long wave speed in $33 \mathrm{~m}$ deep water. Because the squall line was propagating along the coastline, it had a long fetch over shallow coastal waters and significant amplification of the wave due to Proudman resonance could occur. Indeed, sea level oscillations at the Raahe tide gauge and the eyewitness observation ca. $6 \mathrm{~km}$ to the south were of the same magnitude, about $0.5 \mathrm{~m}$. Another event was observed on 4 June 2011 in the Archipelago Sea, connected with a southeastward moving cold front that created a small pressure jump.

\subsubsection{Recent meteotsunamis in Sweden}

Several meteotsunami events have been observed in Sweden in recent years. The eyewitness descriptions very much resemble those reported in Finland: sudden sea level variations of up to $1.5 \mathrm{~m}$ and strong currents. No systematic study of the Swedish events exists to date, but it seems that meteotsunamis typically occur at least a couple of times each summer and can be quite powerful (Ola Kalén, pers. comm.). Based on the available evidence, it seems that conditions for meteotsunami occurrence in Sweden very much resemble those observed in Finland.

On 8 August 2018, a meteotsunami was observed on the western Swedish coast outside the Danish straits. Erik Wickstrand witnessed the event at Lapposand, Hönö, outside Göteborg, and published a video that shows the seafloor revealed by the outflow of water, stranded boats, and after a couple of minutes the inflow of water back to the small bay ${ }^{1}$. According to him, the phenomenon was repeated at least 8-10 times in a similar fashion, before the thunder and rain rolled in. Fisherman Fredrik Andersson, who also observed the event in Hönö, told the newspaper $G T^{2}$ : "I have never seen anything like it. My father is 73 years old and has fished all of his life, and he has never experienced anything like it either."

According to a press release by SMHI (Swedish Meteorological and Hydrological Institute $)^{3}$, the event was caused by a weather front moving eastward over Denmark. The event could be detected in the sea level signal of all Swedish tide gauges around the coast (Ola Kalén, pers. comm.). The tide gauge in Torshamnen, Göteborg, registered 20-25 cm high oscillations, while eyewitnesses reported wave heights of up to $1 \mathrm{~m}$ in Göteborg archipelago.

\footnotetext{
${ }^{1}$ Erik Wickstrand: Sjösprång på Lapposand (Hönö). Published 13 Aug 2018, accessed 23 May 2020. https://youtu.be/4i_FNL3f_9s

${ }^{2}$ GT: Havet försvann - mitt framför Fredriks ögon. Published 11 Aug 2018, accessed 23 May 2020. https://www . expressen.se/gt/havet-forsvann-mitt-framfor-fredriks-ogon/

${ }^{3}$ SMHI: Sjösprång på västkusten. Published 8 Aug 2018, accessed 23 May 2020. https://www.smhi.se/nyhetsarkiv/sjosprang-pa-vastkusten-1.138339
} 
The Swedish word sjösprång (lit. "sea leap") is a somewhat loose term referring to rapid sea level variations, both storm surges with a period of several hours as well as sudden sea level oscillations of shorter period, 5-20 min (Nyberg, 1979). The description of the latter variant clearly points to a meteotsunami: their generation is known to be connected with an air pressure disturbance moving over the sea at a speed close to the long wave speed in the sea. According to Nyberg (1979), the height of the short-period sjösprång on the Swedish coast vary from a few decimetres to 1-2 metres, occasionally even higher. Often there is no local disturbance in weather to be seen; the waves occur in calm weather.

\subsection{Meteotsunamis in Finnish sea level data over the past century}

Apart from the 15 May 1924 meteotsunami, which aroused widespread attention and was thoroughly examined by Renqvist (1926a,b), and the recent events documented in Paper II, there are no scientifically documented occurrences of meteotsunamis in Finland. A systematic study of such events was needed to find out how common meteotsunamis are on the Finnish coast. This was performed in Paper IV.

The study of meteotsunamis is hindered by the spatial and temporal resolution of the sea level measurement network. Even though sea level measurements have been carried out on the Finnish coast for over a century, digital measurements with a sampling interval of less than one hour are not available before 1980 (Section 2.1). However, the Finnish tide gauges have been equipped with recording devices that plotted the sea level as a continuous curve on paper (Fig. 3 in Paper IV), and these paper records exist in the archives of the Finnish Meteorological Institute. There is a lot of undigitized data available on these paper charts.

The sea level data used in Paper IV consists of the original paper charts of the tide gauges of Hanko and Hamina, in the Gulf of Finland (Fig. 1), from the 1920s to 1989. Because analyzing the charts involves a lot of manual work, the scope of the study was restricted to these two tide gauges and to the summer months of May-October. Even though meteotsunami occurrence in winter is possible, as demonstrated by the sea level event of January 1858 in Hiiumaa (Section 4.1.1), Baltic meteotsunamis are predominantly a summertime phenomenon. The sjösprång phenomenon in Sweden is strongly connected to thunderstorms (Nyberg, 1979), which are rare in winter in the region (Mäkelä, 2011). The possible ice cover in the sea further reduces the effect of atmospheric disturbances on sea surface and suppresses sea level oscillations (Section 2.1.1).

The tide gauge charts were browsed through visually, and exceptionally rapid and strong oscillations with a period of max. 2-3 hours were marked for further analysis and digitized. The time series was complemented with events automatically detected from 15-min sea level data since 1980 from three tide gauges in the Gulf of Finland: Hanko, Helsinki, and Hamina. The overlapping ten years in 1980-1989 showed that both the 
visual viewing and the automated algorithm were effective methods of detecting rapid variations in the data, and the results could be combined with reasonable confidence.

The atmospheric origin of the waves was studied using barograms from the nearby coastal stations. In most cases, a small but abrupt pressure jump or drop - or several was found to coincide with the sea level oscillations, indicating that the waves were of meteorological origin. These events were interpreted as small meteotsunamis. A small number of events that were not accompanied by any unusual changes in air pressure were excluded. While notable gaps in the data exist especially because of damping of the sea level records (filtering out of high-frequency signals because of blockages in the pipe connecting the tide gauge well to the sea), the research resulted in a unique dataset of meteotsunami occurrence in the Gulf of Finland spanning nearly a century.

In total, 135 potential events exceeding a location-specific height threshold (10$20 \mathrm{~cm}$ ) were found in the sea level data of the three tide gauges, and 99 (over 70\%) of these were confirmed from the air pressure observations (Table 1 in Paper IV). The rest could not be confirmed because of missing air pressure data. Taking into account that 14 of the events were observed at more than one station, the number of separate events was 121. The longest time series from Hanko (1922-2014) contains 45 events, the time series from Hamina (1928-2014) 65 events (Fig. 5 in Paper IV). While the series from Hanko does not show clear trends in meteotsunami occurrence, in Hamina, meteotsunamis seem to be more common over the latter half of the century than over the first half. Excluding the years with over $80 \%$ of missing data, a least squares fit for Hamina gives an increasing trend which is statistically significant at a level of at least $p=0.01$ (Paper IV).

Three height metrics were used to characterize the heights of the detected meteotsunamis in Paper IV: the maximum height of an individual wave, the total range of variation during the event, and the maximum elevation on top of the background sea level variations. Typical heights of the first two metrics were $10-30 \mathrm{~cm}$, with the highest observed events being close to $60 \mathrm{~cm}$. The maximum elevations were typically roughly half of the total sea level variation. Wave height does not show a statistically significant trend in the time series.

\subsection{Connection to atmospheric phenomena}

In Paper II it was shown that the three sea level events observed in 2010 and 2011 on the Finnish coast occurred during the passage of air pressure disturbances moving at a speed close to the long wave speed in the sea below, confirming their atmospheric origin and meteotsunami-type character. The disturbances were related to different types of weather phenomena: a gust front, squall lines and a cold front.

The connection between meteotsunami occurrence and atmospheric conditions was further studied in Paper IV. On a monthly scale, the months (May-Oct in 19222014) with at least one meteotsunami occurrence were compared with the months with no recorded meteotsunamis. The null hypothesis was that the means in at- 
mospheric parameters between these two sets of months would be equal; this was true for mean sea level pressure, $10 \mathrm{~m}$ wind speed, and the NAO index. In contrast, surface temperature, dew point temperature, and CAPE (convective available potential energy) showed a statistically significant $(p<0.01)$ difference, with larger average values during the months when meteotsunamis were observed (Table 2 in Paper IV). Means of these atmospheric parameters were calculated from reanalysis data.

Thunderstorm days in Finland have been observed by humans since 1887, and since 1960 with an automatic flash counter network. The yearly means of the number of thunder days (1922-2014) showed a statistically significant ( $p=0.02$ ) difference between years when meteotsunamis were recorded and when they were not recorded. However, the number of CG (cloud-to-ground) flashes over the whole continent of Finland and meteotsunami occurrence in the Gulf of Finland did not show such a connection, presumably because the geographical areas differ too much.

More specific location information of CG flashes is available since 1998. The daily and monthly CG flash numbers in the Gulf of Finland region were calculated in Paper IV and compared with meteotsunami occurrence. These numbers were clearly and significantly $(p<0.001)$ higher during days and months when meteotsunamis were recorded compared to other times. On meteotsunami days, CG flash numbers in the Gulf of Finland were over 10 times higher compared to an average summer day of no meteotsunami occurrence (Table 2 in Paper IV). 


\section{Discussion}

There are still large uncertainties in sea level projections, but decisions with a time horizon of 100-200 years have to be made now in coastal management. Adaptive measures, e.g. determining the building elevations of new infrastructure, need to aim at a good balance between the opposing risks of flooding damage (if the flood risk estimates are too low) and larger expenses of flood protection (if unnecessary measures are implemented because the estimates are too high). Probabilistic projections are helpful in this balancing as they can be applied to different situations requiring different safety levels.

Our aim was to present the deep uncertainty in sea level projections as a single probability distribution that includes i) all possible future trajectories of greenhouse gas emissions, ii) the high-impact, low-probability risks such as the possible disintegration of the West Antarctic ice sheet, and iii) regional deviations from the global mean. This was achieved by making a weighted combination of different projections that are based on different methods and treat the uncertainties differently. The process inevitably includes some subjective choices and the results are subject to change as the scientific understanding of sea level rise evolves. However, as Hinkel et al. (2015) point out, the ability of societies to adapt to rising sea levels, e.g. by building flood defences, is faster than the rate of sea level rise given sufficient economical resources are available. While it is good to prepare for rising sea levels, at this point it may be enough to leave possibilities for adaptation open in case the high-end scenarios come true.

Current evidence suggests that the upper limit of potential sea level rise by 2100 lies somewhere in the 1.5-2.5 m range. To reach such high levels, the collapse of the West Antarctic ice sheet should begin during this century. There are recent observations indicating that the disintegration caused by the marine ice sheet instability mechanism is already underway on some of the West Antarctic ice streams, and some modelling results indicate that a widespread collapse can begin during this century (Section 2.2.3), but current scientific knowledge cannot give a definite answer to how fast and significant the retreat will be. Solving this question would require novel ideas and breakthroughs in ice sheet modelling (e.g. Joughin et al., 2012; Jevrejeva et al., 2014).

Future efforts to mitigate greenhouse gas emissions play a crucial role in determining the future of the Antarctic ice sheet and global mean sea level rise (e.g. Winkelmann et al., 2015). Even during this century, the difference between a strong mitigation scenario (RCP2.6) and a business-as-usual scenario (RCP8.5) is significant, and the difference is even more striking in a longer time perspective. By 2300 , a $1.5^{\circ} \mathrm{C}$ warming scenario could peak the sea level at $1.5 \mathrm{~m}$ above the 2000 level (Schaeffer et al., 2012). Limiting warming to $1.5^{\circ} \mathrm{C}$ would require deep emission reductions bringing 
anthropogenic $\mathrm{CO}_{2}$ emissions to zero by 2050 (IPCC, 2018). Stronger warming is likely to commit the world to several metres of sea level rise during the next few centuries. While the postglacial land uplift in Finland, 40-100 cm per century, compensates a significant part of the sea level rise, accelerating sea level rise means that the historical trend of declining mean sea levels will reverse in Finland over time - sooner on the southern coast and later in the north.

At the other end of the sea level spectrum, meteotsunamis on the Finnish coast were studied. The phenomenon of sudden, unexpected large waves has long been known among the coastal residents of Baltic Sea. As a shallow sea with a complex coastal topography, the Baltic Sea is a suitable environment for the resonance effects required to produce sizeable meteotsunami waves. The highest reliably documented meteotsunamis in the Baltic Sea have been 1-1.5 m high, but historical sources point to even higher waves. There is evidence of meteotsunamis from all around the Baltic coasts, indicating that these events are widespread in the Baltic Sea.

The results obtained in this work show that Baltic meteotsunamis are more common than has perhaps been thought previously. While stronger events are rare, small meteotsunami-type oscillations with a height of a few decimetres may occur a few times each summer on the Finnish coast. Although relatively modest in size, Baltic meteotsunamis can in some cases clearly be sufficient to cause at least minor damage and endanger coastal safety. Moreover, it seems that under suitable meteorological circumstances several meteotsunamis can occur within a short time period. For example on 8 August 2010, meteotsunamis were observed both in the Gulf of Finland and the Gulf of Bothnia, caused by separate weather phenomena.

The knowledge of meteotsunami occurrence in the Baltic Sea is still sparse and there is plenty of room for further work. Some suggestions include:

- Compiling a catalogue of all known Baltic meteotsunami events, both historical and contemporary. A systematic study of sea level data and newspaper archives would probably reveal more proof of Baltic meteotsunamis (as e.g. Haslett et al., 2009; Haslett and Bryant, 2009 for the United Kingdom).

- Modelling work to examine the generation mechanisms of meteotsunamis in the Baltic Sea in detail. How can the high Seebär waves observed in the $15^{\text {th }}$ and $18^{\text {th }}$ centuries on the southern Baltic coasts be explained?

- Modelling work to reveal vulnerable locations for meteotsunami occurrence on the coasts of the Baltic Sea.

- Calculating the probability distribution of meteotsunami occurrence at a given location to improve risk assessments of coastal flooding. How well are meteotsunamis represented in the statistics of sea level extremes used in such assessments? 
- What is the reason behind the differing trends of meteotsunami occurrence in Hanko and Hamina, and how will climate change affect meteotsunami occurrence in the future?

- Spreading awareness of Baltic meteotsunamis and strengthening international cooperation among the Baltic Sea countries. 


\section{Conclusions}

The main conclusions of this work, referring to the research objectives presented in Chapter 1, can be summarized as follows:

- Probability distributions of mean sea level change in different locations on the Finnish coast were presented. The regional effect of global sea level rise will be below average, approximately $80 \%$ of the global mean, and postglacial land uplift further counteracts sea level rise in the region. However, sea level rise and significant increases in flooding risks are expected over the $21^{\text {st }}$ century in the Gulf of Finland. In the northern parts of the Gulf of Bothnia, land uplift is strong enough to outweigh sea level rise during this century unless the highest projections come true.

- A total number of 121 potential (over $70 \%$ of them confirmed) meteotsunami events were identified in the sea level data of three tide gauges in the Gulf of Finland 1922-2014, showing that small meteotsunamis occur regularly on the Finnish coast. Typical wave heights at the tide gauges were $10-30 \mathrm{~cm}$, but higher oscillations are possible in vulnerable locations. A statistically significant increasing trend in the number of meteotsunamis was found in Hamina, in the eastern part of the Gulf of Finland, but not in Hanko in the western part of the gulf.

- Weather phenomena that generate meteotsunamis on the Finnish coast include gust fronts, squall lines and cold fronts propagating over the sea at a resonant speed. Meteotsunami occurrence in the Gulf of Finland shows a strong connection to lightning observations. A statistically highly significant difference between meteotsunami months and other months was also found in convective available potential energy (CAPE) which is an indicator of summertime thunderstorm potential. Meteotsunamis in the region seem to occur practically always in connection with thunder. 


\section{Bibliography}

Andersson, H. C., 2002. Influence of long-term regional and large-scale atmospheric circulation on the Baltic sea level. Tellus A: Dynamic Meteorology and Oceanography 54, 76-88.

Averkiev, A. S. and K. A. Klevannyy, 2010. A case study of the impact of cyclonic trajectories on sea-level extremes in the Gulf of Finland. Continental Shelf Research $30,707-714$.

Bakker, A. M., T. E. Wong, K. L. Ruckert, and K. Keller, 2017. Sea-level projections representing the deeply uncertain contribution of the West Antarctic ice sheet. Scientific Reports 7, 1-7.

Bamber, J. and R. Riva, 2010. The sea level fingerprint of recent ice mass fluxes. The Cryosphere 4, 621-627.

Bechle, A. J. and C. H. Wu, 2014. The Lake Michigan meteotsunamis of 1954 revisited. Natural Hazards 74, 155-177.

Church, J., P. Clark, A. Cazenave, J. Gregory, S. Jevrejeva, A. Levermann, M. Merrifield, G. Milne, R. Nerem, P. Nunn, A. Payne, W. Pfeffer, D. Stammer, and A. Unnikrishnan, 2013a. Sea level change. In Stocker, T. et al. (eds.), Climate Change 2013: The Physical Science Basis. Contribution of Working Group I to the Fifth Assessment Report of the Intergovernmental Panel on Climate Change. Cambridge University Press, Cambridge and New York.

Church, J. A., P. U. Clark, A. Cazenave, J. M. Gregory, S. Jevrejeva, A. Levermann, M. A. Merrifield, G. A. Milne, R. S. Nerem, P. D. Nunn, A. J. Payne, W. T. Pfeffer, D. Stammer, and A. S. Unnikrishnan, 2013b. Sea-level rise by 2100. Science 342, 1445.

Credner, R., 1889. Über den "Seebär" der westlichen Ostsee vom 16/17. Mai 1888. III Jahresbericht der geographischen Gesellschaft zu Greifswald 1886-1889 pp. 57-96.

Dangendorf, S., M. Marcos, G. Wöppelmann, C. P. Conrad, T. Frederikse, and R. Riva, 2017. Reassessment of 20th century global mean sea level rise. Proceedings of the National Academy of Sciences 114, 5946-5951.

DeConto, R. M. and D. Pollard, 2016. Contribution of Antarctica to past and future sea-level rise. Nature 531, 591-597.

Defant, A., 1961. Physical oceanography. Pergamon Press, New York. 
Doss, B., 1906. Über ostbaltische Seebären. Gerlands Beiträge zur Geophysik 8, 367399.

Edwards, T. L., M. A. Brandon, G. Durand, N. R. Edwards, N. R. Golledge, P. B. Holden, I. J. Nias, A. J. Payne, C. Ritz, and A. Wernecke, 2019. Revisiting Antarctic ice loss due to marine ice-cliff instability. Nature 566, 58-64.

Ekman, M., 1988. The world's longest continued series of sea level observations. Pure and Applied Geophysics 127, 73-77.

Ekman, M. and J. Mäkinen, 1996. Mean sea surface topography in the Baltic Sea and its transition area to the North Sea: A geodetic solution and comparisons with oceanographic models. Journal of Geophysical Research: Oceans 101 (C5), 1199311999.

Favier, L., G. Durand, S. L. Cornford, G. H. Gudmundsson, O. Gagliardini, F. GilletChaulet, T. Zwinger, A. J. Payne, and A. M. Le Brocq, 2014. Retreat of Pine Island Glacier controlled by marine ice-sheet instability. Nature Climate Change 4, 117-121.

Garner, A. J., J. L. Weiss, A. Parris, R. E. Kopp, R. M. Horton, J. T. Overpeck, and B. P. Horton, 2018. Evolution of 21st century sea level rise projections. Earth's Future 6, 1603-1615.

Golledge, N. R., D. E. Kowalewski, T. R. Naish, R. H. Levy, C. J. Fogwill, and E. G. W. Gasson, 2015. The multi-millennial Antarctic commitment to future sea-level rise. Nature 526, 421-425.

Greenspan, H. P., 1956. The generation of edge waves by moving pressure distributions. Journal of Fluid Mechanics 1, 574-592.

Grinsted, A., S. Jevrejeva, R. E. Riva, and D. Dahl-Jensen, 2015. Sea level rise projections for northern Europe under RCP8.5. Climate Research 64, 15-23.

Grinsted, A., J. C. Moore, and S. Jevrejeva, 2010. Reconstructing sea level from paleo and projected temperatures 200 to 2100 AD. Climate Dynamics 34, 461-472.

Haslett, S. K. and E. A. Bryant, 2009. Meteorological tsunamis in southern Britain: An historical review. The Geographical Review 99, 146-163.

Haslett, S. K., H. E. Mellor, and E. A. Bryant, 2009. Meteo-tsunami hazard associated with summer thunderstorms in the United Kingdom. Physics and Chemistry of the Earth 34, 1016-1022.

Hay, C. C., E. Morrow, R. E. Kopp, and J. X. Mitrovica, 2015. Probabilistic reanalysis of twentieth-century sea-level rise. Nature 517, 481-484.

Hibiya, T. and K. Kajiura, 1982. Origin of the Abiki phenomenon (a kind of seiche) in Nagasaki Bay. Journal of the Oceanographical Society of Japan 38, 172-182. 
Hinkel, J., C. Jaeger, R. J. Nicholls, J. Lowe, O. Renn, and S. Peijun, 2015. Sea-level rise scenarios and coastal risk management. Nature Climate Change 5, 188-190.

Horton, B. P., S. Rahmstorf, S. E. Engelhart, and A. C. Kemp, 2014. Expert assessment of sea-level rise by AD 2100 and AD 2300. Quaternary Science Reviews 84, 1-6.

Horton, R., C. Herweijer, C. Rosenzweig, J. Liu, V. Gornitz, and A. C. Ruane, 2008. Sea level rise projections for current generation CGCMs based on the semi-empirical method. Geophysical Research Letters 35, L02715.

Hünicke, B., E. Zorita, and H. von Storch, 2017. The challenge of Baltic Sea level change. In Harff, J., K. Furmanczyk, and H. von Storch (eds.), Coastline changes of the Baltic Sea from south to east, pp. 37-54. Springer. ISBN 978-3-319-49894-2.

IPCC, 2018. Summary for Policymakers. In Masson-Delmotte, V., P. Zhai, H.-O. Pörtner, D. Roberts, J. Skea, P. R. Shukla, A. Pirani, W. Moufouma-Okia, C. Péan, R. Pidcock, S. Connors, J. Matthews, Y. Chen, X. Zhou, M. Gomis, E. Lonnoy, T. Maycock, M. Tignor, and T. Waterfield (eds.), Global warming of $1.5^{\circ}$ C. An IPCC Special Report on the impacts of global warming of $1.5^{\circ} \mathrm{C}$ above pre-industrial levels and related global greenhouse gas emission pathways, in the context of strengthening the global response to the threat of climate change, sustainable development, and efforts to eradicate poverty. Intergovernmental Panel on Climate Change.

Jansa, A., S. Monserrat, and D. Gomis, 2007. The rissaga of 15 June 2006 in Ciutadella (Menorca), a meteorological tsunami. Advances in Geosciences 12, 1-4.

Jevrejeva, S., A. Grinsted, and J. C. Moore, 2014. Upper limit for sea level projections by 2100. Environmental Research Letters 9, 104008.

Jevrejeva, S., J. C. Moore, and A. Grinsted, 2010. How will sea level respond to changes in natural and anthropogenic forcings by 2100 ? Geophysical Research Letters 37, L07703.

Jevrejeva, S., J. C. Moore, and A. Grinsted, 2012. Sea level projections to AD2500 with a new generation of climate change scenarios. Global and Planetary Change 80, $14-20$.

Johansson, M., 2014. Sea level changes on the Finnish coast and their relationship to atmospheric factors. Finnish Meteorological Institute Contributions 109. http: //urn.fi/URN : ISBN : 978-951-697-832-4.

Johansson, M. M., K. K. Kahma, and H. Boman, 2003. An improved estimate for the long-term mean sea level on the Finnish coast. Geophysica 39, 51-73.

Johansson, M. M., K. K. Kahma, H. Boman, and J. Launiainen, 2004. Scenarios for sea level on the Finnish coast. Boreal Environment Research 9, 153-166. 
Joughin, I. and R. B. Alley, 2011. Stability of the West Antarctic ice sheet in a warming world. Nature Geoscience 4, 506-513.

Joughin, I., R. B. Alley, and D. M. Holland, 2012. Ice-sheet response to oceanic forcing. Science 338, 1172-1176.

Joughin, I., S. B. Das, M. A. King, B. E. Smith, I. M. Howat, and T. Moon, 2008. Seasonal speedup along the western flank of the Greenland Ice Sheet. Science 320, 781-783.

Jylhä, K., M. Kämäräinen, C. Fortelius, H. Gregow, J. Helander, O. Hyvärinen, M. Johansson, A. Karppinen, A. Korpinen, R. Kouznetsov, E. Kurzeneva, U. Leijala, A. Mäkelä, H. Pellikka, S. Saku, J. Sandberg, M. Sofiev, A. Vajda, A. Venäläinen, and J. Vira, 2018. Recent meteorological and marine studies to support nuclear power plant safety in Finland. Energy 165, 1102-1118.

Kahma, K., H. Pellikka, K. Leinonen, U. Leijala, and M. Johansson, 2014. Pitkän aikavälin tulvariskit ja alimmat suositeltavat rakentamiskorkeudet Suomen rannikolla. Raportteja 2014:6, Finnish Meteorological Institute. http ://hdl . handle . net/10138/135226.

Kahma, K., H. Pettersson, H. Boman, and A. Seinä, 1998. Alimmat suositeltavat rakennuskorkeudet Pohjanlahden, Saaristomeren ja Suomenlahden rannikoilla. Merentutkimuslaitos (Finnish Institute of Marine Research).

Katsman, C. A., W. Hazeleger, S. S. Drijfhout, G. J. van Oldenborgh, and G. Burgers, 2008. Climate scenarios of sea level rise for the northeast Atlantic Ocean: a study including the effects of ocean dynamics and gravity changes induced by ice melt. Climatic Change 91, 351-374.

Katsman, C. A., A. Sterl, J. J. Beersma, H. W. van den Brink, J. A. Church, W. Hazeleger, R. E. Kopp, D. Kroon, J. Kwadijk, R. Lammersen, J. Lowe, M. Oppenheimer, H.-P. Plag, J. Ridley, H. von Storch, D. G. Vaughan, P. Vellinga, L. L. A. Vermeersen, R. S. W. van de Wal, and R. Weisse, 2011. Exploring high-end scenarios for local sea level rise to develop flood protection strategies for a low-lying delta - the Netherlands as an example. Climatic Change 109, 617-645.

Kopp, R. E., R. M. DeConto, D. A. Bader, C. C. Hay, R. M. Horton, S. Kulp, M. Oppenheimer, D. Pollard, and B. H. Strauss, 2017. Evolving understanding of Antarctic ice-sheet physics and ambiguity in probabilistic sea-level projections. Earth's Future 5, 1217-1233.

Kopp, R. E., R. M. Horton, C. M. Little, J. X. Mitrovica, M. Oppenheimer, D. Rasmussen, B. H. Strauss, and C. Tebaldi, 2014. Probabilistic 21st and 22nd century sea-level projections at a global network of tide-gauge sites. Earth's Future 2, 383-406. 
Kopp, R. E., A. C. Kemp, K. Bittermann, B. P. Horton, J. P. Donnelly, W. R. Gehrels, C. C. Hay, J. X. Mitrovica, E. D. Morrow, and S. Rahmstorf, 2016. Temperature-driven global sea-level variability in the Common Era. Proceedings of the National Academy of Sciences 113, E1434-E1441.

Kulikov, E. and I. Medvedev, 2013. Variability of the Baltic Sea level and floods in the Gulf of Finland. Oceanology 53, 145-151.

Kulikov, E. and I. Medvedev, 2017. Extreme statistics of storm surges in the Baltic Sea. Oceanology 57, 772-783.

Landerer, F. W., J. H. Jungclaus, and J. Marotzke, 2007. Regional dynamic and steric sea level change in response to the IPCC-A1B scenario. Journal of Physical Oceanography 37, 296-312.

Leppäranta, M. and K. Myrberg, 2009. Physical oceanography of the Baltic Sea. Springer Science \& Business Media. ISBN 978-3-540-79702-9.

Levermann, A., P. U. Clark, B. Marzeion, G. A. Milne, D. Pollard, V. Radic, and A. Robinson, 2013. The multimillennial sea-level commitment of global warming. Proceedings of the National Academy of Sciences 110, 13745-13750.

Lisitzin, E., 1957. On the reducing influence of sea ice on the piling-up of water due to wind stress. Societas Scientiarum Fennica, Commentationes Physico-Mathematicae XX (7), 1-12.

Lisitzin, E., 1964. Contribution to the knowledge of land uplift along the Finnish coast. Fennia 89, 1-22.

Mäkelä, A., 2011. Thunderstorm climatology and lightning location applications in northern Europe. Finnish Meteorological Institute Contributions 91. http: //urn . f i/URN : ISBN : 978-951-697-754-9.

Medvedev, I., A. Rabinovich, and E. Kulikov, 2013. Tidal oscillations in the Baltic Sea. Oceanology 53, 526-538.

Meehl, G. A., T. F. Stocker, W. D. Collins, P. Friedlingstein, A. T. Gaye, J. M. Gregory, A. Kitoh, R. Knutti, J. M. Murphy, A. Noda, S. C. B. Raper, I. G. Watterson, A. J. Weaver, and Z.-C. Zhao, 2007. Global climate projections. In Solomon et al. (eds.), Climate Change 2007: The Physical Science Basis. Contribution of Working Group I to the Fourth Assessment Report of the Intergovernmental Panel on Climate Change. Cambridge University Press, Cambridge and New York.

Meier, H. M., 2015. Projected change - marine physics. In The BACC II Author Team (ed.), Second assessment of climate change for the Baltic Sea basin, pp. 243-252. Springer. ISBN 978-3-319-16005-4. 
Meissner, O., 1924. Zur Frage nach der Entstehung der Seebären. Annalen der Hydrographie und Maritimen Meteorologie 52, 14-15.

Mengel, M., A. Levermann, K. Frieler, A. Robinson, B. Marzeion, and R. Winkelmann, 2016. Future sea level rise constrained by observations and long-term commitment. Proceedings of the National Academy of Sciences 113, 2597-2602.

Mercer, J. H., 1978. West Antarctic ice sheet and $\mathrm{CO}_{2}$ greenhouse effect: a threat of disaster. Nature 271, 321-325.

Merkens, J.-L., L. Reimann, J. Hinkel, and A. T. Vafeidis, 2016. Gridded population projections for the coastal zone under the Shared Socioeconomic Pathways. Global and Planetary Change 145, 57-66.

Mernild, S. H., T. L. Mote, and G. E. Liston, 2011. Greenland ice sheet surface melt extent and trends: 1960-2010. Journal of Glaciology 57, 621-628.

Mitrovica, J., N. Gomez, E. Morrow, C. Hay, K. Latychev, and M. Tamisiea, 2011. On the robustness of predictions of sea level fingerprints. Geophysical Journal International 187, 729-742.

Mitrovica, J. X., M. E. Tamisiea, J. L. Davis, and G. A. Milne, 2001. Recent mass balance of polar ice sheets inferred from patterns of global sea-level change. Nature 409, 1026-1029.

Monserrat, S., I. Vilibić, and A. Rabinovich, 2006. Meteotsunamis: atmospherically induced destructive ocean waves in the tsunami frequency band. Natural Hazards and Earth System Sciences 6, 1035-1051.

Nyberg, L., 1979. Sjösprång. Technical Report HBO PM 233, SMHI (Swedish Meteorological and Hydrological Institute).

Omstedt, A. and L. Nyberg, 1991. Sea level variations during ice-covered periods in the Baltic Sea. Geophysica 27, 41-61.

Oppenheimer, M., B. Glavovic, J. Hinkel, R. van de Wal, A. K. Magnan, A. Abd-Elgawad, R. Cai, M. Cifuentes-Jara, R. M. DeConto, T. Ghosh, J. Hay, F. Isla, B. Marzeion, B. Meyssignac, and Z. Sebesvari, 2019. Sea Level Rise and Implications for Low Lying Islands, Coasts and Communities. In Pörtner, H.-O. et al. (eds.), IPCC Special Report on the Ocean and Cryosphere in a Changing Climate. Intergovernmental Panel on Climate Change, in press.

Pfeffer, W. T., J. T. Harper, and S. O’Neel, 2008. Kinematic constraints on glacier contributions to 21st-century sea-level rise. Science 321, 1340-1343.

Piotrowski, A., 2007. Tsunami AD 1497. Biuletyn Państwowego Instytutu Geologicznego 424, 77-78. Państwowy Instytut Geologiczny, Warszawa. 
Piotrowski, A., W. Szczuciński, P. Sydor, B. Kotrys, M. Rzodkiewicz, and J. Krzymińska, 2017. Sedimentary evidence of extreme storm surge or tsunami events in the southern Baltic Sea (Rogowo area, NW Poland). Geological Quarterly 61, 973-986.

Pritchard, H., S. R. Ligtenberg, H. A. Fricker, D. G. Vaughan, M. R. van den Broeke, and L. Padman, 2012. Antarctic ice-sheet loss driven by basal melting of ice shelves. Nature 484, 502-505.

Proudman, J., 1929. The effects on the sea of changes in atmospheric pressure. Monthly Notices of the Royal Astronomical Society Geophysical Supplement 2 (4), 197-209.

Proudman, J., 1953. Dynamical Oceanography. Methuen \& Co, London; John Wiley \& Sons, New York. Chapter "Travelling Disturbance of Atmospheric Pressure", pp. 295-300.

Rabinovich, A. and S. Monserrat, 1996. Meteorological tsunamis near the Balearic and Kuril Islands: Descriptive and statistical analysis. Natural Hazards 13, 55-90.

Rabinovich, A. B., 2009. Seiches and harbor oscillations. In Kim, Y. C. (ed.), Handbook of Coastal and Ocean Engineering, pp. 193-236. World Scientific, Singapore. ISBN 978-981-281-929-1.

Rahmstorf, S., 2007. A semi-empirical approach to projecting future sea-level rise. Science 315, 368-370.

Renqvist, H., 1926a. Ein Seebär in Finnland. Zur Frage Nach der Entstehung der Seebären. Geografiska Annaler 8, 230-236.

Renqvist, H., 1926b. Ett sjösprång. Föredrag vid Finska Vetenskaps-Societetens sammanträde den 22 februari 1926. Finska Vetenskaps-Societeten Minnesteckningar och Föredrag IV (5), 1-25.

Rignot, E., G. Casassa, P. Gogineni, W. Krabill, A. Rivera, and R. Thomas, 2004. Accelerated ice discharge from the Antarctic Peninsula following the collapse of Larsen B ice shelf. Geophysical Research Letters 31, L18401.

Rignot, E., J. Mouginot, M. Morlighem, H. Seroussi, and B. Scheuchl, 2014. Widespread, rapid grounding line retreat of Pine Island, Thwaites, Smith, and Kohler glaciers, West Antarctica, from 1992 to 2011. Geophysical Research Letters 41, 3502-3509.

Ritz, C., T. L. Edwards, G. Durand, A. J. Payne, V. Peyaud, and R. C. Hindmarsh, 2015. Potential sea-level rise from Antarctic ice-sheet instability constrained by observations. Nature 528, 115-118.

Rohling, E. J., K. Grant, M. Bolshaw, A. Roberts, M. Siddall, C. Hemleben, and M. Kucera, 2009. Antarctic temperature and global sea level closely coupled over the past five glacial cycles. Nature Geoscience 2, 500-504. 
Rohling, E. J., I. D. Haigh, G. L. Foster, A. P. Roberts, and K. M. Grant, 2013. A geological perspective on potential future sea-level rise. Scientific Reports 3, 3461.

Samuelsson, M. and A. Stigebrandt, 1996. Main characteristics of the long-term sea level variability in the Baltic sea. Tellus A 48, 672-683.

Särkkä, J., K. K. Kahma, M. Kämäräinen, M. M. Johansson, and S. Saku, 2017. Simulated extreme sea levels at Helsinki. Boreal Environment Research 22, 299-315.

Scambos, T. A., J. Bohlander, C. Shuman, and P. Skvarca, 2004. Glacier acceleration and thinning after ice shelf collapse in the Larsen B embayment, Antarctica. Geophysical Research Letters 31, L18402.

Scambos, T. A., C. Hulbe, M. Fahnestock, and J. Bohlander, 2000. The link between climate warming and break-up of ice shelves in the Antarctic Peninsula. Journal of Glaciology 46, 516-530.

Schaeffer, M., W. Hare, S. Rahmstorf, and M. Vermeer, 2012. Long-term sea-level rise implied by $1.5^{\circ} \mathrm{C}$ and $2^{\circ} \mathrm{C}$ warming levels. Nature Climate Change 2, 867-870.

Schoof, C., 2007. Ice sheet grounding line dynamics: Steady states, stability, and hysteresis. Journal of Geophysical Research: Earth Surface 112, F03S28.

Seifert, T., F. Tauber, and B. Kayser, 2001. A high resolution spherical grid topography of the Baltic Sea - 2nd edition. Baltic Sea Science Congress, Stockholm, 25-29 Nov 2001, Poster 147. www . io-warnemuende. de/iowtopo.

Šepić, J., I. Međugorac, I. Janeković, N. Dunić, and I. Vilibić, 2016. Multi-meteotsunami event in the Adriatic Sea generated by atmospheric disturbances of 25-26 June 2014. Pure and Applied Geophysics 173, 4117-4138.

Shiklomanov, I., 1993. World fresh water resources. In Gleick, P. H. (ed.), Water in Crisis: A Guide to the World's Fresh Water Resources. Oxford University Press, New York. ISBN 978-019-507-628-8.

Slangen, A., M. Carson, C. Katsman, R. Van de Wal, A. Köhl, L. Vermeersen, and D. Stammer, 2014. Projecting twenty-first century regional sea-level changes. Climatic Change 124, 317-332.

Squire, V. A., 2018. A fresh look at how ocean waves and sea ice interact. Philosophical Transactions of the Royal Society A: Mathematical, Physical and Engineering Sciences 376, 20170342.

Suursaar, Ü. and J. Sooäär, 2007. Decadal variations in mean and extreme sea level values along the Estonian coast of the Baltic Sea. Tellus A: Dynamic Meteorology and Oceanography 59, 249-260. 
Sverdrup, H. U., M. W. Johnson, R. H. Fleming, et al., 1942. The Oceans: Their physics, chemistry, and general biology. Prentice-Hall, New York.

Tamisiea, M., J. Mitrovica, J. Davis, and G. Milne, 2003. Long wavelength sea level and solid surface perturbations driven by polar ice mass variations: Fingerprinting Greenland and Antarctic ice sheet flux. Space Science Reviews 108, 81-93.

Tulvariskityöryhmä, 2009. Tulvariskityöryhmän raportti. Työryhmämuistio 2009:5, Maa- ja metsätalousministeriö (Ministry of Agriculture and Forestry of Finland), Helsinki. http://urn.fi/URN : ISBN : 978-952-453-476-5.

van der Veen, C. J., 2007. Fracture propagation as means of rapidly transferring surface meltwater to the base of glaciers. Geophysical Research Letters 34, L01501.

Vermeer, M., J. Kakkuri, P. Mälkki, H. Boman, K. K. Kahma, and M. Leppäranta, 1988. Land uplift and sea level variability spectrum using fully measured monthly means of tide gauge readings. Finnish Marine Research 256, 1-75.

Vermeer, M. and S. Rahmstorf, 2009. Global sea level linked to global temperature. Proceedings of the National Academy of Sciences of the United States of America 106, 21527-21532.

Vestøl, O., J. Ågren, H. Steffen, H. Kierulf, and L. Tarasov, 2019. NKG2016LU - A new land uplift model for Fennoscandia and the Baltic Region. Journal of Geodesy 93, 1759-1779.

Vilibić, I. and J. Šepić, 2009. Destructive meteotsunamis along the eastern Adriatic coast: Overview. Physics and Chemistry of the Earth 34, 904-917.

Wada, Y., M.-H. Lo, P. J.-F. Yeh, J. T. Reager, J. S. Famiglietti, R.-J. Wu, and Y.-H. Tseng, 2016. Fate of water pumped from underground and contributions to sea-level rise. Nature Climate Change 6, 777-780.

Weertman, J., 1974. Stability of the junction of an ice sheet and an ice shelf. Journal of Glaciology 13, 3-13.

Winkelmann, R., A. Levermann, A. Ridgwell, and K. Caldeira, 2015. Combustion of available fossil fuel resources sufficient to eliminate the Antarctic Ice Sheet. Science Advances 1, e1500589.

Witting, R., 1911. Tidvattnen i Östersjön och Finska viken. Fennia 29 (2).

Witting, R., 1918. Hafsytan, geoidytan och landhöjningen utmed Baltiska hafvet och vid Nordsjön. Fennia 39 (5).

Wolski, T., B. Wiśniewski, A. Giza, H. Kowalewska-Kalkowska, H. Boman, S. Grabbi-Kaiv, T. Hammarklint, J. Holfort, and Ž. Lydeikaite, 2014. Extreme sea levels at selected stations on the Baltic Sea coast. Oceanologia 56, 259-290. 
Zeebe, R. E., A. Ridgwell, and J. C. Zachos, 2016. Anthropogenic carbon release rate unprecedented during the past 66 million years. Nature Geoscience 9, 325-329.

Zwally, H. J., W. Abdalati, T. Herring, K. Larson, J. Saba, and K. Steffen, 2002. Surface melt-induced acceleration of Greenland ice-sheet flow. Science 297, 218-222. 
(C)2012 Elsevier B.V.

Reprinted, with kind permission, from Journal of Marine Systems, 129, 35-46 doi: 10.1016/j.jmarsys.2012.08.007 



\title{
Global sea level rise scenarios adapted to the Finnish coast
}

\author{
Milla M. Johansson *, Hilkka Pellikka, Kimmo K. Kahma, Kimmo Ruosteenoja \\ Finnish Meteorological Institute, P.O. Box 503, FI-00101 Helsinki, Finland
}

\section{A R T I C L E I N F O}

\section{Article history:}

Received 16 December 2011

Received in revised form 3 July 2012

Accepted 20 August 2012

Available online 31 August 2012

\section{Keywords:}

Sea level scenarios

Regional sea level rise

Baltic Sea

Finnish coast

\begin{abstract}
A B S T R A C T
We calculate scenarios for the mean sea level on the Finnish coast by combining the land uplift, wind-induced changes in the local sea level, and large-scale sea level rise due to changes in ocean density and circulation and melting of land-based ice. The wind-induced changes were estimated by utilising their correlation with the zonal geostrophic wind, which explains $84-89 \%$ of the observed interannual variability of sea level on the Finnish coast. Future scenarios were based on the geostrophic wind projections from nine global circulation models. Land uplift rates are 4.1-9.9 mm/yr, determined from the observations after filtering out the wind-induced effect. A $26-155 \mathrm{~cm}$ range for the global mean sea level rise up to 2100 was obtained by combining several recently published scenarios. This rise is geographically unevenly distributed, and on the Finnish coast it is estimated to be only $24-126 \mathrm{~cm}$. Relative sea level change in the Gulf of Finland in $2000-2100$ is projected to be $+29 \mathrm{~cm}(-22$ to $+92 \mathrm{~cm})$. A change of $-5 \mathrm{~cm}(-66$ to $+65 \mathrm{~cm})$ is projected for the Bothnian Sea, and $-27 \mathrm{~cm}(-72$ to $+28 \mathrm{~cm})$ for the Bothnian Bay, where the land uplift is stronger.

(c) 2012 Elsevier B.V. All rights reserved.
\end{abstract}

\section{Introduction}

Estimates of the future behaviour of the sea level are important for coastal activities, including construction and planning, as well as flood protection. Thus, there is a continuous interest in sea level scenarios based on the most recent knowledge of the effects of climate change. For practical applications like risk analyses, not only an ensemble of possible scenarios, but also estimates of their probabilities are of interest. This study responds to this need on the Finnish coast in the north-eastern Baltic Sea.

The semi-enclosed Baltic Sea is connected to the North Atlantic Ocean through the narrow and shallow Danish Straits. The water flows in and out through the straits, allowing the sea level changes in the global ocean to penetrate into the Baltic Sea as well. The long-term changes in the relative sea level on the coastline of Finland are thus determined by a combination of local and large-scale processes: local meteorologically induced changes in the sea level and local postglacial land uplift, as well as the large-scale sea level rise due to melting of ice sheets, glaciers and ice caps, thermal expansion of the oceans, and changes in ocean dynamics (Johansson et al., 2004). All these factors need to be taken into account when analysing the past and projecting the future behaviour of the local sea level.

The Baltic Sea level varies remarkably due to regional meteorological conditions. The interannual fluctuations in the annual average sea levels on the Finnish coast are of the order of $20 \mathrm{~cm}$. In earlier studies,

\footnotetext{
* Corresponding author. Tel.: + 358295392127.

E-mail addresses: milla.johansson@fmi.fi (M.M. Johansson), hilkka.pellikka@fmi.fi (H. Pellikka), kimmo.kahma@fmi.fi (K.K. Kahma), kimmo.ruosteenoja@fmi.fi (K. Ruosteenoja)
}

this variability was found to be related to the North Atlantic Oscillation (NAO) index, the correlation being especially strong in winter and in the northeastern part of the Baltic Sea (e.g., Andersson, 2002; Johansson et al., 2003; Kahma, 1999; Suursaar and Sooäär, 2007; Suursaar et al., 2006). A positive NAO index coincides with anomalously strong westerlies over the North Atlantic. This westerly flow tends to push water through the Danish Straits into the Baltic Sea, thus altering the total water volume in the semi-enclosed basin. Such variations affect the Baltic Sea level by several tens of centimetres on an intra-annual time scale. In addition, a prevailing westerly flow redistributes water inside the Baltic Sea basin in such a way that the sea level is highest in the northeastern part of the basin; this sea level tilt reinforces the effect of water volume changes on the Finnish coast (Johansson et al., 2003). Other phenomena might also contribute to the link between a high NAO index and high sea levels in the Baltic Sea: e.g. a high NAO index correlates with high precipitation, which through river runoff affects the salinity gradient in the Baltic Sea. However, compared to the fluctuations induced by the water transport, such phenomena are of secondary importance.

The variability of the NAO index, and the corresponding fluctuations in sea level are also visible on a decadal time scale. For instance, in the 1980s and 1990s the mean sea level on the Finnish coast was anomalously high. This behaviour coincides with a high NAO index during these decades (Johansson et al., 2003). Thus, this meteorological contribution is relevant in studies of long-term mean sea level scenarios.

In Scandinavia the postglacial land uplift, i.e., the slow recovery of the Earth's crust from the pressure of the ice masses during the last ice age, is still ongoing and has been extensively analysed. Traditionally, the most accurate data for studying the land uplift were the long-term time series of mean sea level measured by tide gauges. 
These data yield the vertical land movement in relation to the sea surface (e.g. Hela, 1953; Lisitzin, 1964; Vermeer et al., 1988). In some earlier papers, it was customary to call this relative movement relative land uplift (Johansson et al., 2004; Vermeer et al., 1988), although actually it is a combination of the sea level change and the crustal movement. Recently, new data obtained from permanent GPS stations allow the calculation of vertical land movement independently of the sea level change (Lidberg et al., 2007; Richter et al., 2011; Vestøl, 2006). To avoid misinterpretation, in this paper we denote the absolute crustal movements as "land uplift", while the term "relative sea level change" refers to the change from a coastal viewpoint as measured by the tide gauges (sea level change minus land uplift).

In this paper we use the term "large-scale sea level change" to refer to sea level changes which have their main sources outside the Baltic Sea, but which still affect the Baltic Sea. These include melting of ice sheets, glaciers and ice caps as well as thermal expansion of the oceans, and changes in ocean dynamics. These phenomena cause global-scale sea level changes. The average rate of the global mean sea level rise during the 20th century was $1.7 \pm 0.5 \mathrm{~mm} / \mathrm{yr}$, as estimated in the Fourth Assessment Report (AR4) of the Intergovernmental Panel on Climate Change (IPCC; Bindoff et al., 2007). There is evidence that the global mean sea level rise has accelerated. Satellite altimetry measurements show a rate of $3.3 \pm 0.4 \mathrm{~mm} / \mathrm{yr}$ in 1993-2007 (Cazenave and Llovel, 2010).

The Third Assessment Report (TAR) of the IPCC (Church et al., 2001) projected a global average sea level rise of $9-88 \mathrm{~cm}$ by the end of this century. Johansson et al. (2004) calculated sea level scenarios for the Finnish coast by combining the TAR scenarios with local land uplift and scenarios for meteorological forcing. The possibility that the large-scale sea level rise due to thermal expansion and melting of land-based ice might be geographically unevenly distributed was not taken into account in that paper: the global average scenarios were applied to the Baltic Sea unchanged. Johansson et al. (2004) concluded that the decline of the relative sea level observed on the Finnish coast during the 20th century is likely to cease in the Gulf of Finland. The mean of six different emission scenarios projected a -4 to $+5 \mathrm{~cm}$ change from 2000 to 2093, while the whole scenario range extended from -30 to $+47 \mathrm{~cm}$. In the Gulf of Bothnia, where land uplift is stronger, the decline of the sea level was projected to continue. The intermediate projection ranged from -49 to $-18 \mathrm{~cm}$, while the entire scenario range extended from -74 to $+25 \mathrm{~cm}$. The differences among the local values mainly originated from different land uplift rates, ranging from 3.1 to $9.0 \mathrm{~mm} / \mathrm{yr}$. The uncertainty of several tens of centimetres in the global sea level rise scenarios was reflected on the Finnish coast as well.

Meier et al. (2004) presented sea level scenarios for the Baltic Sea based on dynamical modelling of the local processes combined with the global sea level scenarios of the TAR. The scenarios showed that land uplift will compensate for the sea level rise for low-end scenarios, and in the northern parts of the Baltic Sea even for the intermediate scenario, but according to the maximum scenario the relative sea level would rise over the entire Baltic Sea area.

Since TAR, new knowledge on global sea level rise and its spatial distribution has been obtained, and thus the sea level projections for the Finnish coast by Johansson et al. (2004) are outdated. The AR4 provided updates for the global sea level scenarios. The sea level was projected to rise by $18-59 \mathrm{~cm}$ in the $21 \mathrm{st}$ century (Meehl et al., 2007). In addition, an ice-sheet discharge term of up to $17 \mathrm{~cm}$ was suggested to account for the possible effect of rapid dynamical changes in the Greenland and Antarctic ice sheets. Because current models lack the ability to simulate such changes, this estimate was based on an assumed link between the sea level rise induced by these dynamical changes, and the global mean surface temperature.

The new IPCC scenarios have encountered criticism as being too conservative, because the full effect of ice sheet dynamics was not included in the numerical estimate (e.g. Hansen, 2007). Since 1990, global mean sea level has been rising faster than the models predict (Rahmstorf et al., 2007), indicating possible deficiencies in the ability of the models to handle this issue. After AR4, a number of higher sea level projections have been published. Several authors (Grinsted et al., 2010; Horton et al., 2008; Jevrejeva et al., 2010; Jevrejeva et al., 2012; Rahmstorf, 2007; Vermeer and Rahmstorf, 2009) used semi-empirical relations between sea level and temperature (or radiative forcing); projections of sea-level rise ranging from 36 to $190 \mathrm{~cm}$ were obtained. Pfeffer et al. (2008) made an effort to estimate the highest possible rate of ice discharge from the Greenland and West Antarctic ice sheets, concluding an upper limit of $200 \mathrm{~cm}$ for the sea level rise by 2100 .

The global-scale sea level rise is not distributed evenly, as revealed by satellite altimetry (e.g. Cazenave and Llovel, 2010). These regional differences arise from changes in ocean density and dynamics as well as gravitational effects and land movements due to redistribution of water and ice on the Earth's surface (Bindoff et al., 2007). Large ice masses attract sea water by gravitation, causing the water to pile up around the ice mass. When the ice melts, the gravitational attraction is relieved, and the water retreats. According to modelling results, the sea level will decline near the melting ice mass, while in areas far away it will rise more than on average (Mitrovica et al., 2001; Tamisiea et al., 2003). Thus, depending on whether the global average sea level rise is caused by thermal expansion, melting of the Greenland ice sheet, of the Antarctic ice sheet, or of the small glaciers and ice caps around the world, the result is a different regional contribution on the Finnish coast. From the Finnish viewpoint, the source of the projected sea level rise thus is of great importance.

This study aims at updating the sea level scenarios of Johansson et al. (2004). In Section 2 the data are presented. In Section 3 the local effects of meteorological forcing and land uplift are considered. We examine the possibility of more efficiently explaining the meteorologically-induced component of sea level variations by the local time-mean geostrophic wind rather than the NAO index used in previous studies (Johansson et al. 2003, 2004). The land uplift rates are estimated from the sea level time series after subtracting the response to meteorological forcing and the past large-scale sea level rise. In Section 4, scenarios are constructed. To obtain a probability distribution for future large-scale sea level rise, we combine different global sea level projections presented in literature. The uneven geographical distribution of the sea level rise and specifically the regional contribution on the Finnish coast is estimated. This has not been done previously for the Finnish coast, as the earlier projections were based on the TAR global mean sea level scenarios solely. To respond to the practical demands, the probability distributions for the large-scale sea level scenarios are estimated. Finally, the large-scale sea level rise is combined with the land uplift and meteorologically induced variations to obtain projections for the local relative sea level change on the Finnish coast.

\section{Data}

\subsection{Sea level data}

The sea level is continuously measured at 13 tide gauge stations on the Finnish coast, most of which have been operating since the 1920s (Fig. 1, Table 1). The longest time series, beginning in October 1887, comes from Hanko, and the shortest one, beginning in January 1933 , from Rauma. The sea level was generally recorded at 4-hour intervals up to 1970 and at 1-hour intervals since then. In this study, the sea level values are given relative to the Finnish height reference N2000 (Saaranen et al., 2009).

Annual mean sea levels were calculated from the observations after an extensive check of data quality. For a detailed discussion on the data quality and associated problems, see Johansson et al. (2001). For various reasons, observations are missing occasionally. 


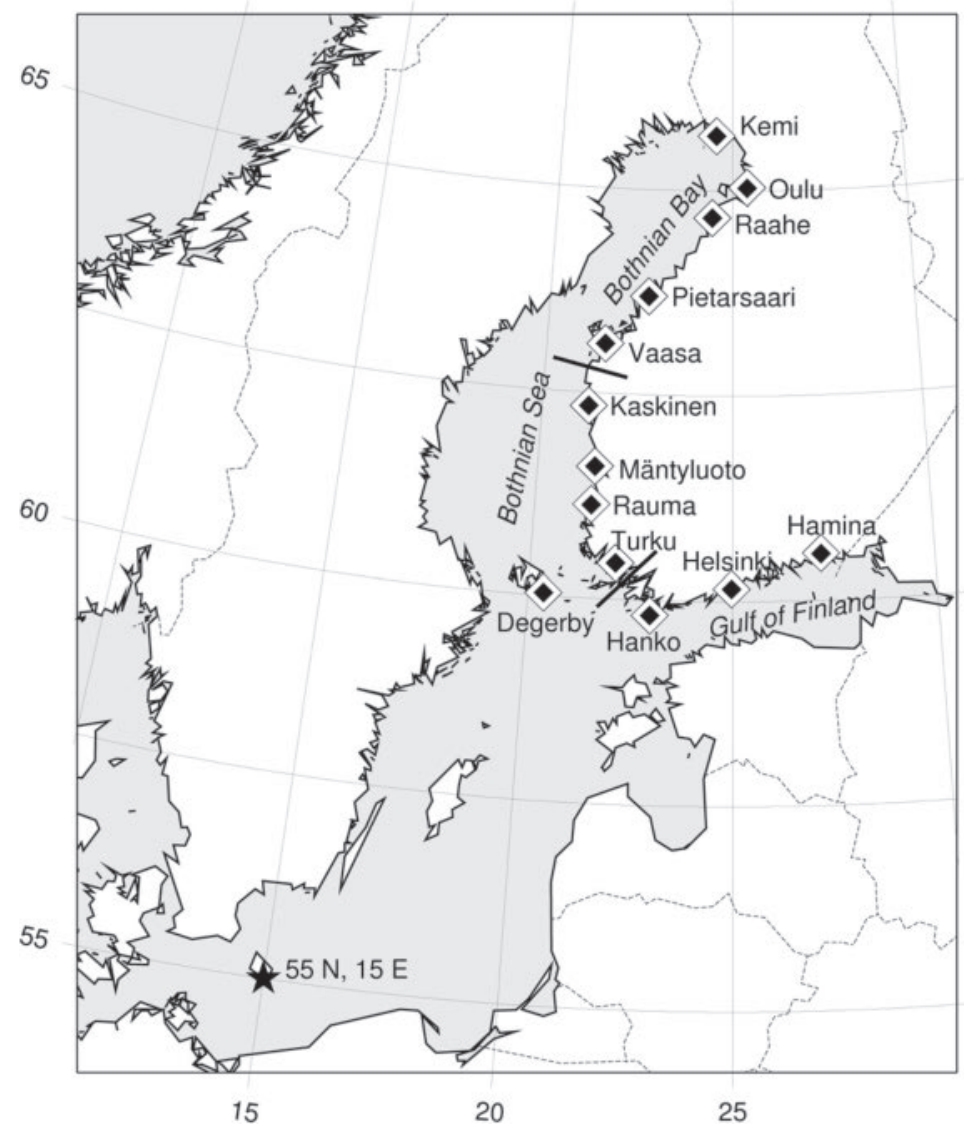

Fig. 1. Locations of the Finnish tide gauges (diamonds), and the point from which the geostrophic wind data utilised in the study were selected (star). The black lines represent the division of the Finnish coastline into three sections: the Bothnian Bay, the Bothnian Sea and the Gulf of Finland.

These were patched by linear interpolation, averaging the observations from adjacent stations weighted by inverse geographical distances. In the case of Kemi and Hamina, linear extrapolation using the observations from two adjoining stations was applied. Some gaps were still left in the 4-hourly data; no interpolation could be done if data from one of the adjacent stations were missing. Other corrections on the data have also been made based on a quality

Table 1

The Finnish tide gauge measurements, including the lengths of the time series of annual mean sea levels and percentages of missing or interpolated 4-hourly sea level values.

\begin{tabular}{lllc}
\hline Tide gauge & $\begin{array}{l}\text { Years } \\
\text { of data }\end{array}$ & $\begin{array}{l}\text { Missing } \\
\text { values (\%) }\end{array}$ & $\begin{array}{l}\text { Interpolated or } \\
\text { corrected values (\%) }\end{array}$ \\
\hline Kemi & $1923-2010$ & 0.13 & 4.6 \\
Oulu & $1923-2010$ & 0.22 & 6.9 \\
Raahe & $1923-2010$ & 0.13 & 9.2 \\
Pietarsaari & $1922-2010$ & 0.08 & 2.0 \\
Vaasa & $1922-2010$ & 0.03 & 8.5 \\
Kaskinen & $1927-2010$ & 0.34 & 4.6 \\
Mäntyluoto & $1925-2010$ & 0.26 & 1.8 \\
Rauma & $1933-2010$ & 0.12 & 0.8 \\
Turku & $1922-2010$ & 0.06 & 3.9 \\
Degerby & $1924-2010$ & 0.01 & 6.4 \\
Hanko & $1888-2010$ & 1.6 & 15 \\
Helsinki & $1904-2010$ & 0.00 & 1.1 \\
Hamina & $1929-2010$ & 0.01 & 2.5 \\
\hline
\end{tabular}

check. For instance, the observations at Hanko were biased when the pipe connecting the tide gauge well to the sea was partially blocked, and at the same time high precipitation raised the water table around the well over the sea level (Johansson et al., 2001).

The percentages of missing, interpolated or corrected sea level data are given in Table 1 . The effect of interpolation on the annual mean sea levels was tested by generating complete interpolated data for years for which observations exist, and then comparing the annual mean sea level derived from the interpolated data with that actually observed. The root-mean-square (rms) difference between the interpolated and observed annual mean was between 5 and $12 \mathrm{~mm}$ depending on the place, and the maximum difference between the interpolated and observed annual mean was only $41 \mathrm{~mm}$; these are almost an order of magnitude smaller than the natural year-to-year variation of the annual mean values (Fig. 2). The mean difference between the interpolated data and the observed data over the whole observation period (about 80 years) varied randomly from station to station and was between -7 and $+6 \mathrm{~mm}$. This shows that the gauge network is dense enough that no bias was introduced by the interpolation. At the ends of the network, where extrapolation rather than interpolation had to be used, the rms difference was slightly larger, $24 \mathrm{~mm}$ at Kemi and $14 \mathrm{~mm}$ at Hamina. The maximum difference in a single year was $96 \mathrm{~mm}$ at Kemi and $39 \mathrm{~mm}$ at Hamina. Even these differences are smaller than the natural variation of the annual means of different years. 


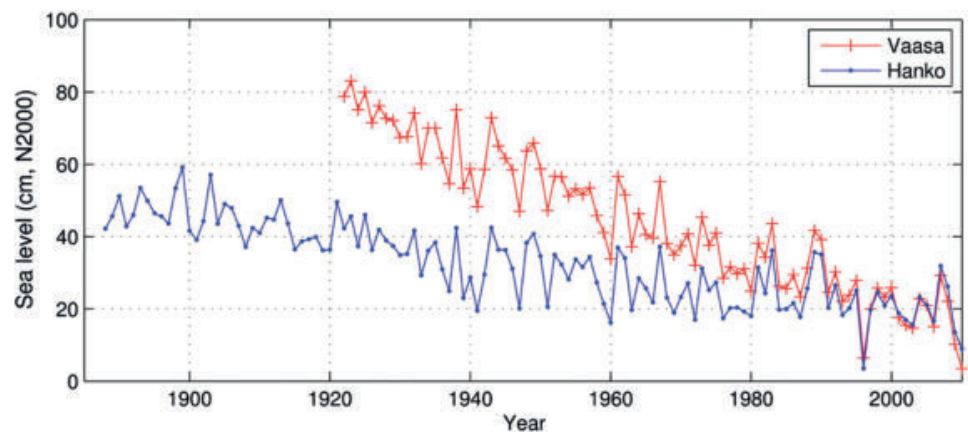

Fig. 2. Annual mean sea levels measured at Vaasa $\left(63^{\circ} 05^{\prime} \mathrm{N}, 21^{\circ} 34^{\prime} \mathrm{E}\right)$ and Hanko $\left(59^{\circ} 49^{\prime} \mathrm{N}, 22^{\circ} 59^{\prime} \mathrm{E}\right)$ tide gauges.

\subsection{Geostrophic wind data and scenarios}

To obtain the observation-based geostrophic winds, daily mean sea-level pressure fields for the years 1899-2010 were utilised (U.S. National Center for Atmospheric Research [CISL/Data Support Section] et al., 2011; Trenberth and Paolino, 1980). In this data set, sea level pressure is represented on a $5^{\circ}$ latitude/longitude grid extending from $15^{\circ} \mathrm{N}$ to $85^{\circ} \mathrm{N}$. The zonal $\left(U_{g}\right)$ and meridional $\left(V_{g}\right)$ geostrophic wind components were calculated from the pressure gradient:

$U_{g}=-\frac{1}{f \rho} \frac{\partial p}{\partial y}, V_{g}=\frac{1}{f \rho} \frac{\partial p}{\partial x}$

where $f$ stands for the latitude-dependent Coriolis parameter, and $\rho$ for the air density, which is a function of the pressure and temperature (in calculating the observation-based $\left(U_{g}, V_{g}\right)$, a constant value of $283 \mathrm{~K}$ was used). The wind components were first calculated at the intermediate points of the grid and then interpolated to the $5^{\circ}$ latitude/longitude grid. Annual means were calculated from the daily data. The rather coarse spatial resolution was considered adequate, as those phenomena on which the relationship between the wind and sea level variations on annual and longer time scales are based (see Section 1) occur on the spatial scale of the entire Baltic Sea.

Future scenarios for geostrophic wind were based on global climate model runs performed under the A1B, A2 and B1 greenhouse gas scenarios of the Special Report on Emission Scenarios (SRES; Nakićenović et al., 2000). The model-simulated daily sea level pressure and temperature data were downloaded from the Coupled Model Intercomparison Project 3 (CMIP3) archive (Meehl et al., 2007); nine high-resolution models representing different research centres were selected for the analysis (BCCR-BCM2.0, CGCM3.1 (T63), CNRM-CM3, ECHAM5/MPI-OM, GFDL-CM2.1, IPSL-CM4, MIROC3.2 (hires), MRI-CGCM2.3.2 and NCAR-CCSM3; for further information, see Gregow et al., 2011). The components of geostrophic wind were derived from 24-h mean surface pressure fields simulated by the models. For each model, $U_{g}$ and $V_{g}$ were first calculated at the intermediate grid points of the native grid of the model. In order to build multi-model statistics, the components were thereafter interpolated onto a common $2.5^{\circ}$ latitude/longitude grid. The procedure is documented in more detail in Gregow et al. (2011). Model-based daily pressure data were available for the baseline period 1961-2000 and for two future periods, 2046-2065 and 2081-2100. Data from all the nine models were available for the A1B scenario, while only seven models were available for A2 and eight models for B1.

Since the 24-hour averaging tends to reduce the magnitude of the geostrophic wind, and there are other systematic differences between the model-simulated and observed time-mean geostrophic winds (Fig. 1 of Gregow et al., 2011), a so-called delta-change approach was used to estimate the future geostrophic wind. This method assumes that the modelling biases will remain unchanged in the future. We first calculated, for each of the nine models and both future periods (2046-2065 and 2081-2100), a deviation of the 20-year mean from the baseline period 1961-2000 mean. These anomalies were then added to the temporal mean of 1961-2000 calculated from the observations (the DS010.0 dataset) to obtain the scenarios for each model and time period. From these values, nine-model averages were calculated for each period and SRES scenario, and also the maxima and minima among the nine-model three-scenario ensemble.

Unfortunately, the CMIP3 archive provides daily model data for two discrete 20-year time slices only. For individual model runs, these 20 -year means are affected considerably by decadal-scale internal variability of the climate system. However, as the internal variability in the individual models behaves independently, it is largely cancelled out by averaging over the nine models.

\section{Observed long-term sea level variations}

\subsection{Components of sea level variations}

As presented in Section 1, the relative sea level change $h$ observed at a Finnish coastal observation site $i$ is a combination of various processes:

$h(t, i)=R(i)+h_{l}(t, i)-u(i) t+w(t, i)+\varepsilon(t, i)$

where $t$ is the time since the reference year $t_{0}$. The term $h_{l}$ represents the large-scale sea level change since $t_{0}$. The postglacial land uplift proceeds at a constant local rate $u$ within the time scale considered. The local meteorologically-induced contribution to the sea level is represented by a location-dependent quantity $w$. The constant $R$ relates the sea level values to the Finnish height reference N2000, and $\varepsilon$ represents the residual variations.

We approximate the large-scale sea level change by a linear rise for the 20th century: $h_{l}=g$ t, where the rate $g$ is approximated by the global mean sea level rise rate of $1.7 \pm 0.5 \mathrm{~mm} / \mathrm{yr}$ (Bindoff et al., 2007). As the sea level rise is distributed unevenly, the applicability of the global mean to the Baltic Sea can be questioned - see Section 5 for discussion and suggested ways ahead. The assumption of a linear rise is only applicable for the 20th century, as during the latest decades the sea level rise has accelerated (Bindoff et al., 2007; Cazenave and Llovel, 2010).

\subsection{Meteorological forcing}

Johansson et al. (2003, 2004) estimated the meteorologically induced component $w$ by utilising the correlation of the sea level fluctuations with the NAO index. In the present study, the NAO index is 
replaced by the zonal geostrophic wind over the southern Baltic Sea, since this can represent the local physical mechanism - a westerly flow - more closely than the NAO index, which is based on large-scale surface pressure variations over the entire Northern Atlantic. The interannual variability in the two long-term factors in Eq. (2) - large-scale sea level rise, and land uplift - is much smaller than the observed variability of up to $20 \mathrm{~cm}$ (Fig. 2). As a first approximation, the sea level rise and land uplift have proceeded linearly during the 20th century. Thus, to yield the detrended sea level anomalies, the long-term changes were filtered out from the time series simply by subtracting the linear trend.

The correlations between the annual mean zonal geostrophic wind and the annual mean sea level anomalies on the Finnish tide gauges were calculated for each wind grid point in an area covering the Baltic Sea and the surroundings (from $20^{\circ} \mathrm{W}$ to $40^{\circ} \mathrm{E}$ and $45^{\circ} \mathrm{N}$ to $75^{\circ} \mathrm{N}$ ). The correlation was strongest for the zonal wind component $U_{g}$ at the grid point located in the southern Baltic Sea $\left(55^{\circ} \mathrm{N}, 15^{\circ} \mathrm{E}\right.$, Fig. 3). The meridional wind component $V_{g}$ did not show any remarkable correlation with the sea levels.

Regression coefficients representing the dependence of the sea level at the tide gauges on the zonal geostrophic wind at the grid point $55^{\circ} \mathrm{N}, 15^{\circ} \mathrm{E}$ were then calculated with a linear regression using the maximum likelihood effective variance method, which takes into account the uncertainties in both variables (Table 2). The regression was calculated for the sea level data up to 2000 , before which the assumption of a linear large-scale sea level rise (constant $g$ ) was assumed to hold. The regression explains $84-89 \%$ of the interannual variability of the sea levels, as revealed by the coefficients of determination $R^{2}$. This correlation is stronger than the correlation between the sea levels and the NAO index reported in Johansson et al. (2003); the NAO index explained only $37-46 \%$ of the interannual variability.

Next, estimates for the annual wind-induced sea level component $w$ for the years 1899-2010 were calculated using the linear relation with the zonal geostrophic wind:

$w(t, i)=p_{i} U_{g}(t)$

where $p_{i}$ is the site-dependent regression coefficient obtained by the regression above. The average of $w$ on the Finnish coast in 1961-2000 amounts to $20-24 \mathrm{~cm}$ (Table 2), indicating that the water level was $20-24 \mathrm{~cm}$ higher than it would have been in the hypothetical situation with zero average zonal wind.

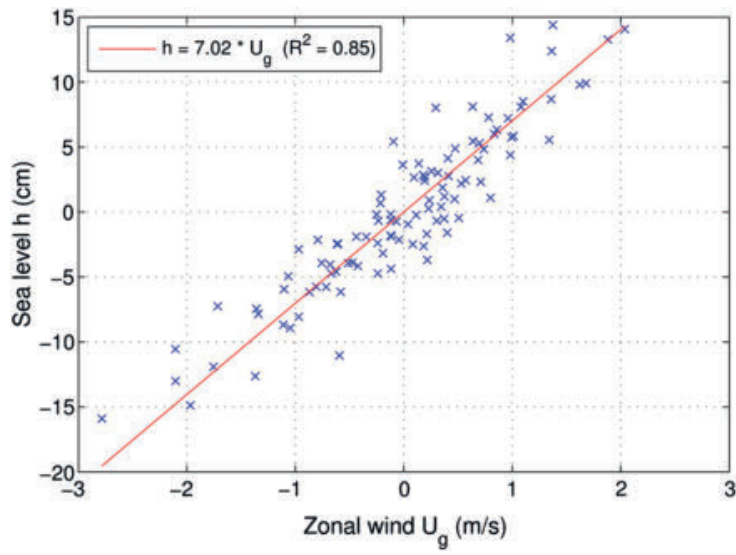

Fig. 3. Detrended annual mean sea level anomalies at Hanko as a function of the detrended anomaly of the annual mean zonal geostrophic wind at the southern Baltic Sea grid point $\left(55^{\circ} \mathrm{N}, 15^{\circ} \mathrm{E}\right)$ in $1899-2000$. A regression line obtained by the maximum likelihood effective variance method is also shown.
Table 2

The regression coefficients $p_{i}$ (with error estimates corresponding to one standard deviation), and the coefficients of determination $R^{2}$ for the relationship between the detrended annual mean zonal geostrophic wind $U_{g}$ at $55^{\circ} \mathrm{N}, 15^{\circ} \mathrm{E}$, and sea level at the Finnish tide gauge stations up to year 2000. The coefficients of determination for the meridional wind component $V_{g}$ are also given, as well as the mean wind-induced sea level components in 1961-2000, obtained using Eq. (3).

\begin{tabular}{lllll}
\hline Tide gauge & $p_{i}\left(\mathrm{~cm} / \mathrm{ms}^{-1}\right)$ & $R^{2}\left(U_{g}\right)$ & $R^{2}\left(V_{g}\right)$ & Mean $w(\mathrm{~cm})$ \\
\hline Kemi & $7.6 \pm 1.2$ & 0.84 & 0.04 & 23 \\
Oulu & $7.4 \pm 1.2$ & 0.85 & 0.05 & 23 \\
Raahe & $7.4 \pm 1.2$ & 0.86 & 0.06 & 22 \\
Pietarsaari & $7.2 \pm 1.2$ & 0.87 & 0.06 & 22 \\
Vaasa & $7.0 \pm 1.1$ & 0.89 & 0.08 & 21 \\
Kaskinen & $7.0 \pm 1.2$ & 0.88 & 0.06 & 21 \\
Mäntyluoto & $6.9 \pm 1.1$ & 0.87 & 0.09 & 21 \\
Rauma & $6.8 \pm 1.2$ & 0.88 & 0.10 & 21 \\
Turku & $6.9 \pm 1.1$ & 0.87 & 0.11 & 21 \\
Degerby & $6.5 \pm 1.1$ & 0.86 & 0.11 & 20 \\
Hanko & $7.0 \pm 1.0$ & 0.85 & 0.16 & 21 \\
Helsinki & $7.2 \pm 1.0$ & 0.87 & 0.17 & 22 \\
Hamina & $7.8 \pm 1.3$ & 0.89 & 0.16 & 24 \\
\hline
\end{tabular}

\subsection{Land uplift rates}

After subtracting the estimated $w$ and the sea level rise $g t$ from the observed sea level time series up to 2000 , a linear regression in time was applied to the residual, yielding estimates for the land uplift rates $u$ (Table 3 ) and the terms $R$. The linear trend in $\varepsilon$ was assumed to be small and neglected.

The land uplift rates obtained are 0.83-0.96 mm/yr higher than the corresponding estimates given in Johansson et al. (2004). This can be explained by considering the linear trend $r_{h}$ of the observed sea level time series as the sum of the large-scale sea level rise $g$, land uplift $u$, trend in the wind-induced component $r_{w}$ and a trend in the residual variations $r_{\varepsilon}$ :

$r_{h}=g-u+r_{w}+r_{\varepsilon}$

The observed sea level trend $\left(r_{h}\right)$ is the same in this study and Johansson et al. (2004). For the large-scale sea level rise $g$, they used a value of $1.5 \mathrm{~mm} / \mathrm{yr}$, while $1.7 \mathrm{~mm} / \mathrm{yr}$ is used here. Their NAO-based estimate for the meteorologically induced sea level component had no considerable trend, while the trend in the wind-induced component $w$ here is $0.54-0.64 \mathrm{~mm} / \mathrm{yr}$ in $1899-2000$. As the land uplift rate $u=g+r_{w}-r_{h}$, these differences mostly explain why the rates obtained here are higher than those obtained by Johansson et al. (2004).

Table 3

Land uplift rates calculated from the reduced sea level time series up to 2000 after subtracting the wind-induced fluctuations and the large-scale sea level rise of $1.7 \pm$ $0.5 \mathrm{~mm} / \mathrm{yr}$ (from Bindoff et al., 2007). The error estimates correspond to two standard deviations.

\begin{tabular}{lll}
\hline Tide gauge & $u(\mathrm{~mm} / \mathrm{yr})$ & Johansson et al. (2004) \\
\hline Kemi & $9.66 \pm 0.75$ & $8.70 \pm 0.74$ \\
Oulu & $9.30 \pm 0.74$ & $8.37 \pm 0.73$ \\
Raahe & $9.66 \pm 0.73$ & $8.72 \pm 0.72$ \\
Pietarsaari & $9.74 \pm 0.71$ & $8.81 \pm 0.71$ \\
Vaasa & $9.85 \pm 0.69$ & $8.96 \pm 0.67$ \\
Kaskinen & $9.36 \pm 0.71$ & $8.49 \pm 0.69$ \\
Mäntyluoto & $8.49 \pm 0.70$ & $7.57 \pm 0.67$ \\
Rauma & $7.67 \pm 0.71$ & $6.85 \pm 0.70$ \\
Turku & $6.33 \pm 0.70$ & $5.44 \pm 0.66$ \\
Degerby & $6.48 \pm 0.68$ & $5.63 \pm 0.66$ \\
Hanko & $5.00 \pm 0.68$ & $4.13 \pm 0.65$ \\
Helsinki & $4.37 \pm 0.69$ & $3.51 \pm 0.66$ \\
Hamina & $4.05 \pm 0.75$ & $3.12 \pm 0.72$ \\
\hline
\end{tabular}


The uncertainty estimates for $u$ (Table 3 ) were based on the uncertainties in the components from which $u$ was calculated, assuming that the different components are independent:

$\Delta u^{2}=\Delta r_{d}^{2}+\Delta g^{2}+\Delta r_{w}^{2}$

where $\Delta r_{d}$ is the uncertainty in the observational trend from which the wind-induced component has been subtracted, $r_{d}=r_{h}-r_{w} . \Delta g$ is the uncertainty in the large-scale sea level rise $(0.5 \mathrm{~mm} / \mathrm{yr})$ and $\Delta r_{w}$ the uncertainty in the trend of the wind-induced component.

\subsection{Computational estimate for annual mean sea levels}

A computational estimate for the annual mean sea level was calculated for the period 1899-2010 by summing up the terms $u t, R, w$ and gt (Fig. 4). The rms error of the estimate is $2-3 \mathrm{~cm}$ and the bias zero for every tide gauge in 1899-2000. In 2001-2010, the rms error is 6-7 $\mathrm{cm}$ and the bias 5-6 cm. This indicates that rather than a degradation of the correlation between wind and sea levels in the year-to-year variations, the larger error during the latest decade is due to the observations being systematically higher than the estimate. The estimate for the years 2000-2010 was based on extrapolation of the linear trend $g$ of 1899-2000, and this trend evidently underestimates the accelerated large-scale sea level rise of the latest years.

Calculated in all the overlapping 50-year periods between 1899 and 2000, the linear relation between the zonal geostrophic wind and sea levels has not changed markedly; for instance at Hanko the coefficients of determination vary between 0.82 and 0.90 , and the regression coefficients $\left(6.7-7.3 \mathrm{~cm} / \mathrm{ms}^{-1}\right)$ are well within the uncertainty limits of the coefficient determined for the full 102-year period $\left(7.0 \pm 1.0 \mathrm{~cm} / \mathrm{ms}^{-1}\right)$. Thus, it is reasonable to assume that the relation will also hold for the future. The parameter $R$ and land uplift rate $u$ obtained from the past observations will remain unchanged, and can also be applied to the future. On the contrary, the large-scale sea level trend $g=1.7 \mathrm{~mm} / \mathrm{yr}$ cannot be extrapolated into the future, and therefore projections for $h_{l}$ will be constructed in the next section.

\section{Sea level scenarios}

\subsection{Weighting the global scenarios}

To obtain a probability distribution for the global sea level rise in the 21st century, several recent sea level projections were combined. When combining projections based on different methods, each of them was given a weight (Table 4). The leading principles in determining the weights were:

i) We concentrated on recent scenarios. Every scenario which we judged to be based on physically justified assumptions was given a weight of 1 .

ii) If similar assumptions were used in several different papers, this was taken into account by reducing the weight to 0.5 .

iii) A scenario based on a review of several papers was given a weight of 2 .

We point out that while our weights are subjective, and different choices may also be justifiable, the result is robust. We will discuss the effect of weight choices and the robustness of the resulting scenarios in Section 4.4.

One approach to predicting sea level rise is to model each contributor to the rise numerically and add these components together to form the total scenario. Steric sea level change (mainly due to the thermal expansion of seawater) is calculated from the modelled ocean temperature change, and melting of mountain glaciers and small ice caps is assessed using modelled and observed sensitivity parameters that link the glacier mass balance to temperature change. The ice sheet contribution is estimated with numerical ice sheet models and supplemented with scaling of recent observations, as the models do not yet include all relevant dynamical processes. The AR4 (Meehl et al., 2007) provides an extensive summary of numerous recent modelling studies and was thus given the highest weight of 2 . Katsman et al. (2008) and Katsman et al. (2011) combine modelling with different scaling methods and expert judgement to assess the sea level rise in northeast Atlantic Ocean, and were given a weight of 1 . We included both publications because of differences in methodology and temperature scenarios.

Another approach to estimating sea level rise is to construct a semi-empirical model, which links the sea level rise to temperature change, and then use the atmosphere-ocean general circulation model (AOGCM) projections for temperature to find the corresponding change in sea level. Rahmstorf (2007) assumed a linear relationship between global mean surface temperature and the rate of sea level change. His results were updated by Horton et al. (2008), who used a similar method, but with more recent AR4 scenarios for global warming. The analysis of Rahmstorf (2007) encompasses a wider range of emission scenarios, however, so we included both publications. Grinsted et al. (2010), Jevrejeva et al. (2010), Jevrejeva et al. (2012), and Vermeer and Rahmstorf (2009) used more complex semi-empirical models with different calibration periods and, in some cases, physical constraints on the model parameters. As the

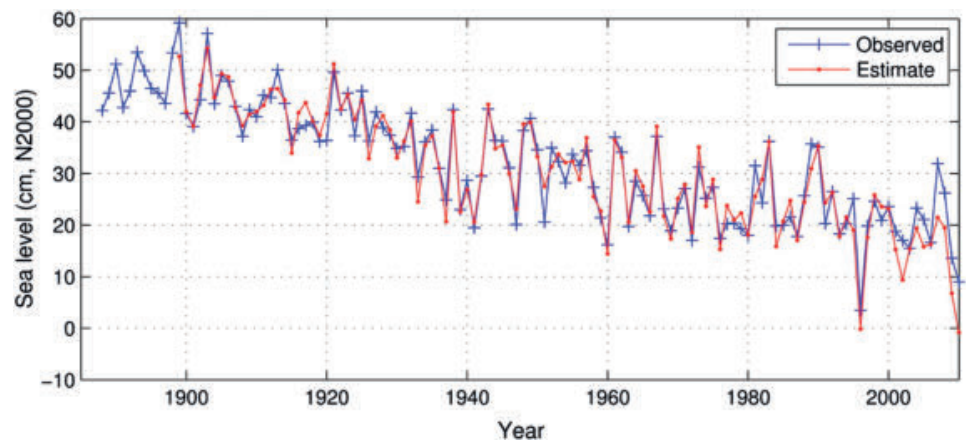

Fig. 4. Annual mean sea levels measured at Hanko, together with the computational estimate obtained as a sum of land uplift, large-scale sea level rise (1.7 mm/yr) and the wind-induced component. 
Table 4

Projections for global sea level rise used to calculate the combined scenario. Each projection is given a subjective weight: see Section 4.1 for details.

\begin{tabular}{llcl}
\hline Publication & Global sea level rise $(\mathrm{cm})$ & Probability range & Time period \\
\hline IPCC AR4 (Meehl et al., 2007) & $18-76^{\mathrm{a}}$ & $5-95 \%$ & $2090-2099$ relative to $1980-1999$ \\
Katsman et al. (2011) & $52-111$ & & $1990-2100$ \\
Pfeffer et al. (2008) & $79-201$ & $10-90 \%$ & be 2100 \\
Katsman et al. (2008) & $34-87^{\text {b }}$ & $5-95 \%$ & $1990-2100$ \\
Jevrejeva et al. (2012) & $36-165$ & $5-95 \%$ & 2100 relative to 1980-2000 \\
Jevrejeva et al. (2010) & $44-178$ & $5-95 \%$ & 2100 relative to 1980-2000 \\
Grinsted et al. (2010) & $72-160^{\mathrm{c}}$ & $5-95 \%$ (based on AR4) & $2090-2099$ relative to 1980-1999 \\
Vermeer and Rahmstorf (2009) & $75-190$ & $5-95 \%$ (based on AR4) & $1990-2100$ \\
Horton et al. (2008) & $47-100$ & $2.5-97.5 \%$ (based on TAR) & 0.5 \\
Rahmstorf (2007) & $50-140$ & 0.5 & 0.5 \\
\hline
\end{tabular}

a Scaled-up ice sheet discharge included, see Table 10.7 of Meehl et al. (2007).

b Value for global mean sea level rise: local gravity corrections and local steric changes are not included in contrast to the total values presented by Katsman et al. (2008).

c Their experiment 'Moberg', which gives the best fit to global sea level reconstruction.

semi-empirical projections are based on somewhat similar assumptions, and to compensate their large proportion in the scenario ensemble ( 6 out of 10 ), a weight of 0.5 was applied to them.

Given the inadequacy of the physical models, semi-empirical methods provide a valuable alternative perspective to the sea level problem, but they also have drawbacks (e.g., Church et al., 2011). Perhaps most importantly, models of this type extrapolate the past sea level behaviour into the future even though the physical processes causing sea level rise may well be different - for example, reducing glacier area will decrease the importance of their melting in the future; on the other hand, the response of the Greenland and Antarctic ice sheets may be nonlinear and unprecedented in recent history due to the complicated dynamical processes involved. In addition, the scaling method to be used to adapt these scenarios to the Finnish coast (Section 4.2) adds to the uncertainty. Applying a lower weight for the semiempirical scenarios also accounts for these uncertainties.

Finally, Pfeffer et al. (2008) attempted to calculate an upper limit for the poorly known ice sheet dynamics term by considering maximal feasible ice discharge from outlet glaciers constrained by bedrock topography. Their estimate was included with a weight of 1 as a plausible upper limit of sea level rise by 2100 .

\subsection{Scaling the large-scale sea level rise for the Finnish coast}

The projected sea level rise is not geographically uniform. Current AOGCM results bear many similarities in the spatial distribution of sea level rise, but diverge in details. Thus it is not yet possible to give any exact regional values for sea level rise. We approach the question of the large-scale sea level rise on the Finnish coast with a componentwise scaling. The scenarios of Katsman et al. (2008, 2011), and Pfeffer et al. (2008) were presented as a sum of different contributing components: ocean density and circulation changes, melting of Greenland and Antarctic ice sheets and smaller glaciers and ice caps, and also terrestrial storage in Katsman et al. (2008) (Table 5). Each of these components was scaled for the Finnish coast as follows.

For the sea level rise due to ocean density and circulation changes, most of the models simulate larger than global average values for the northeast Atlantic region (Meehl et al., 2007; Slangen et al., 2011). An ensemble mean of 16 models forced by the A1B greenhouse gas scenario shows a sea level rise for the eastern part of the North Sea 10-15 cm larger than average (Meehl et al., 2007; their Fig. 10.32). We applied these values to the thermal expansion scenario of Pfeffer et al. (2008) to yield a rise of $40-45 \mathrm{~cm}$ for the Finnish coast. Katsman et al. (2008) analysed corresponding model results for the northeastern Atlantic Ocean and concluded that while some models do not show any difference compared with the global mean, others result in an additional regional rise due to reduction in the strength of the meridional overturning circulation. This local increment was estimated to reach up to $4.2 \mathrm{~cm}$ per degree of global warming, or
$16.7 \mathrm{~cm}$ by 2100 according to the maximum temperature scenario of Katsman et al. (2008). We applied the northeast Atlantic values given by Katsman et al. (2008) unchanged for the Finnish coast.

The contribution of glaciers and ice sheets is expected to be smaller than the global average on the Finnish coast. Mitrovica et al. (2001) presented maps for sea level change resulting separately from melting of the Greenland and Antarctic ice sheets and small glaciers and ice caps due to changes in Earth's gravity field. The Greenland (Antarctic) contribution is smaller (larger) in the Baltic Sea region than the global average. The contributions of glaciers and ice sheets were scaled according to the coefficients derived from the figures of Mitrovica et al. (2001) and Tamisiea et al. (2003). The Finnish coast was divided into three sections (Fig. 1), for which the coefficients had the following values for Greenland, Antarctica and small glaciers and ice caps, respectively: Gulf of Finland 0.15, 1.05, 0.65; Bothnian Sea 0.05, 1.05, 0.65; and Bothnian Bay 0, 1.05, 0.5.

As an example, the scaling approach for the Gulf of Finland is presented in detail in Table 5. Summing up the different contributions, the ratio of the large-scale sea level rise in the Gulf of Finland to the global average is $0.71-0.97$ (for all the scenarios plotted in Fig. 5), the average ratio being 0.83 . Similar scaling was done for the Bothnian Sea and the Bothnian Bay, resulting in average ratios of 0.82 and 0.79 , respectively.

The componentwise scaling cannot be applied to the semiempirical projections, as the projected rise is not attributed to different sources. Thus we used a scaling approach based on the relation between the global average sea level rise and the resulting large-scale sea level rise on the Finnish coast. The relations from those scenarios which were adapted to the Finnish coast are plotted in Fig. 5. The recent observed sea level rise (Cazenave and Llovel, 2010) was also adapted to the Finnish coast with the componentwise scaling, resulting in a regional rise of $2.07 \mathrm{~mm} / \mathrm{yr}$, in contrast to the global value of $2.85 \mathrm{~mm} / \mathrm{yr}$ (sum of climate-related contributions for 1993-2007; this rise, which can be attributed to different factors, is slightly smaller than the observed altimetry-based mean sea level rise of $3.3 \pm 0.4 \mathrm{~mm} / \mathrm{yr}$ ). Also plotted in Fig. 5 is a rough estimate of the sea level rise in the North Sea region from Slangen et al. (2011), who made an attempt to calculate the regional pattern of the AR4 sea level scenarios. The contribution of different factors is estimated from their Fig. 2 (GIA excluded) for the emission scenario A1B.

To construct a continuous function, a curve was fitted to the points in Fig. 5: a linear least squares fit up to $111 \mathrm{~cm}$ of global rise, and a second-order fit from $111 \mathrm{~cm}$ to the uppermost point, which corresponds to the high scenario of Pfeffer et al. (2008). The justification for bending the line is that there is a physical reason to assume a lower regional to global ratio for high sea level scenarios, as the share of the ice sheet contribution is larger. The straight line was forced to pass through the point corresponding to the observed sea level rise (Cazenave and Llovel, 2010). There is no reason to force the line to pass through the origin; even in conditions of zero average 
Table 5

Adapting the global sea level scenarios to the Finnish coast, with the Gulf of Finland as an example. The global and northeast Atlantic values are taken from the references. The values for the Gulf of Finland are the result of our scaling approach (Section 4.2).

\begin{tabular}{|c|c|c|c|c|c|c|c|c|c|c|c|c|}
\hline & \multicolumn{4}{|c|}{$\begin{array}{l}\text { Pfeffer et al. (2008), } \\
\text { by } 2100\end{array}$} & \multicolumn{4}{|c|}{$\begin{array}{l}\text { Katsman et al. (2008) } \\
1990-2100\end{array}$} & \multicolumn{4}{|c|}{$\begin{array}{l}\text { Katsman et al. (2011) } \\
1990-2100\end{array}$} \\
\hline & \multicolumn{2}{|c|}{ Global } & \multicolumn{2}{|c|}{ Gulf of Finland } & \multicolumn{2}{|c|}{ Northeast Atlantic } & \multicolumn{2}{|c|}{ Gulf of Finland } & \multicolumn{2}{|c|}{ Global } & \multicolumn{2}{|c|}{ Gulf of Finland } \\
\hline & Min & Max & Min & Max & Min & Max & Min & Max & Min & Max & Min & Max \\
\hline Thermal expansion & 30 & 30 & 40 & 45 & 15.0 & 47.8 & 15.0 & 47.8 & 12 & 49 & 14.5 & 59.3 \\
\hline Greenland & 16.5 & 53.8 & 2.5 & 8.1 & 0.4 & 6.4 & 0.3 & 3.8 & 13 & 22 & 2.0 & 3.3 \\
\hline Antarctica & 14.6 & 61.9 & 15.3 & 65.0 & -3.4 & 23.5 & -3.3 & 22.5 & -1 & 41 & -1.1 & 43.1 \\
\hline Glaciers and ice caps & 17.4 & 55.1 & 11.3 & 35.8 & 6.5 & 15.4 & 5.3 & 12.5 & 7 & 20 & 4.6 & 13 \\
\hline Terrestrial storage & - & - & - & - & 0 & 4 & 0 & 4 & - & - & - & - \\
\hline Observed 1990-2005 & - & - & - & - & 3 & 5 & 3 & 5 & - & - & - & - \\
\hline Total & 78.5 & 200.8 & 69.1 & 153.9 & 30.1 & 81.0 & 28.2 & 77.0 & 52.4 & 110.6 & 37.1 & 100.6 \\
\hline \multirow[t]{2}{*}{ Ratio Gulf of Finland/global } & \multirow{2}{*}{\multicolumn{4}{|c|}{$\begin{array}{l}0.88 \text { (Minimum scenario) } \\
0.77 \text { (Maximum scenario) }\end{array}$}} & \multicolumn{4}{|c|}{0.82 (Minimum scenario) } & \multicolumn{4}{|c|}{0.71 (Minimum scenario) } \\
\hline & & & & & $0.88(\mathrm{~N}$ & um sce & & & 0.91 & imum $s$ & io) & \\
\hline
\end{tabular}

global sea level rise, a sea level change on the Finnish coast might result, and vice versa. The analysis was repeated for the three coastal sections (Gulf of Finland, Bothnian Sea and Bothnian Bay). The global semi-empirical projections were then scaled using the functions obtained.

\subsection{Combined probability distributions}

In total, ten global sea level rise projections (Table 4) were used to form probability distributions for the sea level rise up to 2100 in relation to the year 2000. As the projections have slightly different time spans, they were first scaled to correspond to a 100 -year time span (2000-2100) by assuming a linear evolution in time. Three values for 2100 were constructed from each projection: minimum, intermediate, and maximum scenarios. The intermediate scenario usually corresponds to the mean of the best estimates of the different emission scenarios. If no such information was available, the intermediate scenario was set at the arithmetic mean of the minimum and maximum scenarios.

A three-parameter Weibull distribution was fitted to each of the ten projections. For several of the projections, a probability range was given (Table 4). For those projections which did not explicitly state the probabilities, but which were based on the $5 \%$ to $95 \%$ range of the AR4 temperature scenarios (Horton et al., 2008;

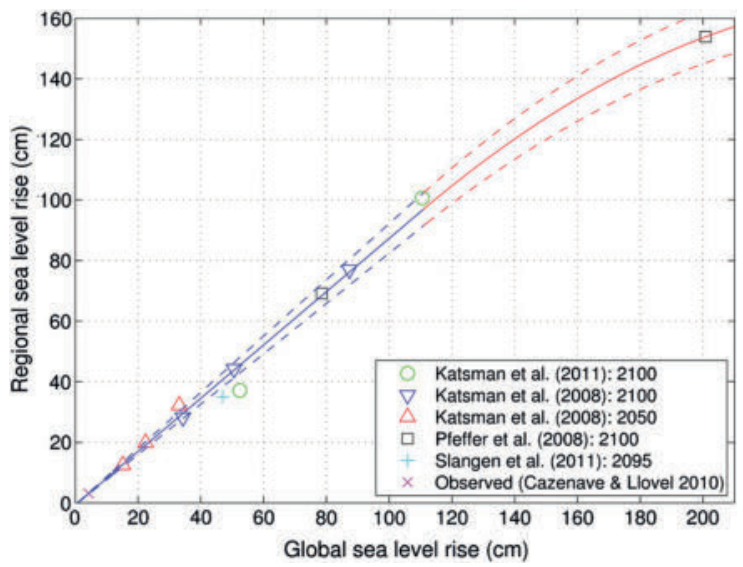

Fig. 5. Regional sea level rise in the Gulf of Finland as a function of the global mean sea level rise, derived from different publications. Global values are adapted to the Finnish coast as demonstrated in Table 5. The function fitted to the points is shown with 5\% and $95 \%$ confidence limits; a linear fit was applied to global sea level rise up to $111 \mathrm{~cm}$, and a second order fit for values higher than that; for details see Section 4.2.
Vermeer and Rahmstorf, 2009) or the $2.5 \%$ to $97.5 \%$ range of the TAR scenarios (Rahmstorf, 2007), the corresponding probability levels were applied. The projection of Katsman et al. $(2011)$ was assumed to correspond to a probability range of $5 \%$ to $95 \%$, as this was the range used in most of the other projections. A probability level of 99\% was assigned to the high scenario of Pfeffer et al. (2008), as this scenario is considered the physically plausible upper limit of sea level change. This choice lowers the upper limits of the combined scenarios in 2100 by a few centimetres, compared to assigning a probability level of $95 \%$ to the high scenario of Pfeffer et al. (2008).

The intermediate scenario was assumed to be the most likely, and thus the distributions were fitted iteratively to bring the peak of the probability density function close to the intermediate scenario. Many of the distributions have a positive skew, that is, the intermediate scenario is closer to the minimum scenario than to the maximum scenario.

The probability density functions thus obtained were weighted using the weights given in Table 4 and summed up to form a combined distribution. This procedure was repeated for both the global mean sea level rise and the scaled large-scale sea level rise on the three sections of the Finnish coast (Fig. 6). The resulting 5\% to 95\% probability range of global mean sea level rise in 2000-2100 is $26-155 \mathrm{~cm}$, whereas the large-scale sea level rise is projected to affect the Gulf of Finland by $24-126 \mathrm{~cm}$, the Bothnian Sea by $24-122 \mathrm{~cm}$, and the Bothnian Bay by $24-115 \mathrm{~cm}$.

\subsection{Effects of weighting and scaling}

The effect of the weighting procedure on the resulting probability distributions for the large-scale sea level rise was estimated by calculating an ensemble of 200 combined probability distributions using the above method, but applying random weights between 0.5 and 1 for each of the projections. The only exception was the AR4 projection, for which the randomly applied weight was doubled. A non-weighted calculation was also conducted, applying a weight of one for all the projections.

The results for the Gulf of Finland are presented in Fig. 7. The spread of the probability distributions based on random weights is about $10 \mathrm{~cm}$ at most. Thus, the method is robust and not highly sensitive to the subjective choice of weights. The distribution based on the weights estimated in Section 4.1 is on the lower limit of the range of the random weight ensemble, while the distribution based on equal weights is on the upper limit.

As a result of the scaling the difference between the global sea level rise projection and the projections for the Finnish coast is $29-40 \mathrm{~cm}$ for the upper (95\%) estimate. When the combined scenario is calculated by applying the semi-empirical projections to the Finnish coast without scaling, but still using the componentwise scaling for the other 


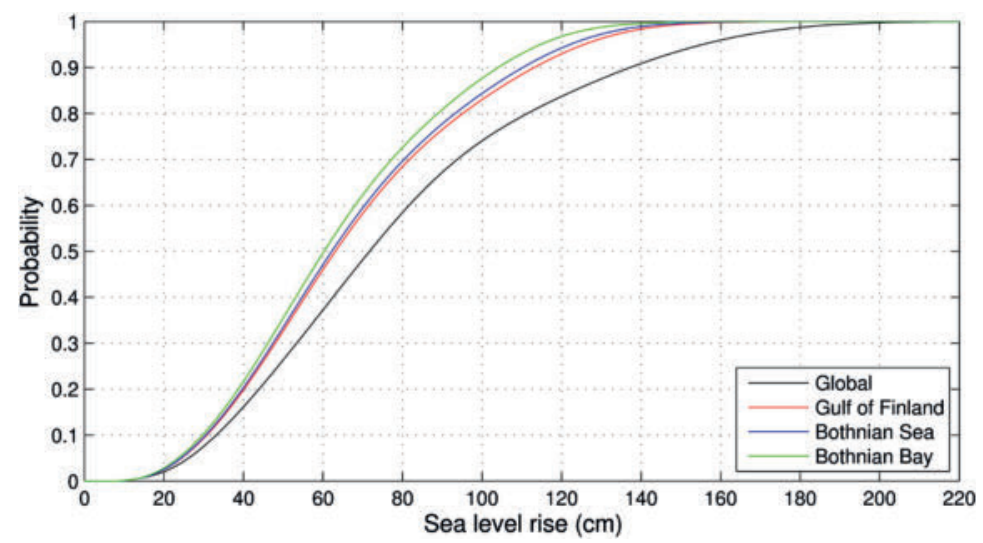

Fig. 6. Cumulative probability distributions of the global mean sea level rise and the large-scale sea level rise on the Finnish coastal sections, in 2100 relative to the year 2000.

projections, the upper (95\%) estimates of the combined large-scale sea level scenarios are raised by $11-18 \mathrm{~cm}$.

The choice of the scaling method has a smaller effect: if the scaling is based on the upper and lower confidence limits of the scaling function (dashed lines in Fig. 5), the 95\% level of the large-scale sea level projections is changed less than $4 \mathrm{~cm}$ compared to the best estimate (solid line in Fig. 5). If the semi-empirical scenarios are scaled with a constant coefficient determined by calculating the average ratios of regional to global sea level rise from points in Fig. 5 (around 0.8 depending on the coastal section), the result is within $1 \mathrm{~cm}$ from the best estimate.

Thus, applying the scaling is justified, as the contribution of the ice sheets is evidently smaller on the Finnish coast than globally, and the scaling takes this into account. The details of the scaling method play a lesser role.

\subsection{Relative sea level change on the Finnish coast}

Combining the probability distributions of the large-scale sea level rise with those of the land uplift and wind-induced changes in the local sea levels yields probability distributions for the relative sea level change from 2000 to 2100 on the Finnish coast. Probability distributions for the land uplift rates $u$ were obtained by fitting normal distributions according to the parameters given in Table 3. Probability distributions for the wind-induced changes were obtained as follows.

Scenarios for the 20-year mean zonal component of geostrophic wind over the southern Baltic Sea are given in Table 6. On average, the models project an increase for all three greenhouse gas scenarios. The B1 scenario represents the smallest increase, while in 2046-2065 the increase is largest in the A1B scenario $(0.70 \mathrm{~m} / \mathrm{s}$ from the reference period 1961-2000), and in 2081-2100 in the A2 scenario $(1.22 \mathrm{~m} / \mathrm{s})$. As the differences among the three SRES scenarios are smaller than one-third of the range between the minimum and maximum changes derived from the ensemble containing all model runs under all the three SRES scenarios (Table 6, the six-model averages), it was considered best to use the A1B scenario as an intermediate estimate in calculating the future wind-induced sea level component $w$. The A1B scenario represents a greenhouse gas forcing of intermediate strength and, moreover, for that scenario simulations were available for all the nine models. The uncertainties in $U_{g}$ were taken into account by assuming the difference between the maximum and minimum wind scenarios from the nine-model three-scenario ensemble to be equivalent to \pm 2 standard deviations (about $95 \%$ of the

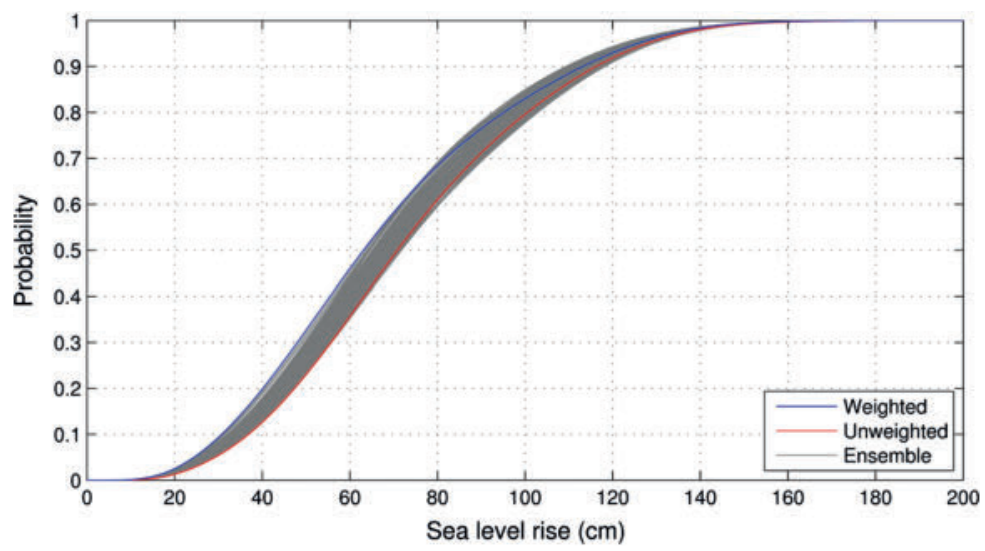

Fig. 7. An ensemble of 200 combined cumulative probability distributions for the effect of the large-scale sea level rise on the Gulf of Finland, obtained by applying random weights for the different projections ("ensemble"). The probability distribution obtained by applying the weights chosen in Section 4.1 ("weighted"), as well as the one obtained by applying a weight of one for every projection ("unweighted") are also shown. 


\section{Table 6}

20 -Year means for the zonal component of the geostrophic wind at $55^{\circ} \mathrm{N}, 15^{\circ} \mathrm{E}$ in the southern Baltic Sea; projections calculated with the delta-change approach using the reference period 1961-2000, for which the observed mean value was $3.04 \mathrm{~m} / \mathrm{s}$. As the $\mathrm{A} 2$ and $\mathrm{B} 1$ scenarios were not available for all models, we also present six-model averages using only those models for which all the scenarios were given.

\begin{tabular}{|c|c|c|c|c|c|c|c|c|c|c|}
\hline \multirow[b]{2}{*}{ Years } & \multicolumn{5}{|c|}{$\mathrm{U}_{\mathrm{g}}(\mathrm{m} / \mathrm{s})$, nine-model averages } & \multicolumn{5}{|c|}{$\mathrm{U}_{\mathrm{g}}(\mathrm{m} / \mathrm{s})$, six-model averages } \\
\hline & $\mathrm{A} 1 \mathrm{~B}$ & A2 & B1 & Min & Max & A1B & A2 & B1 & Min & Max \\
\hline 2046-2065 & 3.74 & $3.64^{\mathrm{a}}$ & $3.23^{\mathrm{b}}$ & 2.52 & 4.22 & 3.67 & 3.58 & 3.24 & 2.52 & 4.22 \\
\hline $2081-2100$ & 3.98 & $4.26^{\mathrm{a}}$ & $3.53^{\mathrm{b}}$ & 3.04 & 5.27 & 3.99 & 4.18 & 3.53 & 3.04 & 5.27 \\
\hline
\end{tabular}

projections falling within this interval), with the uncertainty being normally distributed around the nine-model mean A1B projection. A normal distribution was applied for $p_{i}$ based on the regression coefficients and their uncertainties in Table 2, and this was combined with the distribution of $U_{g}$ to yield the probability distribution for $w$.

Scenarios for $w$ at selected locations are given in Table 7. The increasing zonal winds lead to increasing sea levels; on average a $6-7 \mathrm{~cm}$ increase in the long-term mean sea levels on the Finnish coast up to 2081-2100, while the maximum scenario projects an increase of $15-19 \mathrm{~cm}$ and the minimum scenario a decrease of $3-4 \mathrm{~cm}$. The differences between the two future time periods of 2046-2065 and 2081-2100 are at most $4 \mathrm{~cm}$. This suggests that even if the 2081-2100 period is not centred around the year 2100, this should not result in an inaccuracy larger than $1-2 \mathrm{~cm}$ when the 2081-2100 scenario is chosen to represent the year 2100 and combined with the large-scale sea level scenarios.

The resulting scenarios for the relative sea level change on the Finnish coast by 2100 are presented in Table 8 . The probability density functions of the individual components of the scenario at Hanko in 2100 are given in Fig. 8. The figure illustrates the fact that the large-scale sea level rise is the main source of uncertainty, the uncertainties in land uplift and wind-induced changes being of secondary importance.

\section{Summary and discussion}

The interannual sea level variability on the Finnish coast correlates positively with zonal geostrophic wind over the southern Baltic Sea, and this correlation accounts for $84-89 \%$ of the observed variability (Fig. 3; Table 2). The correlation is stronger than that between the sea level and the NAO index, which only explained $37-46 \%$ of the sea level variability (Johansson et al., 2003). As this correlation has not changed markedly during the 20th century (Section 3.4), we assumed it to hold in the future also. The responses to future changes in the zonal geostrophic wind correspond to a change in the long-term mean sea levels on the Finnish coast ranging from a $4 \mathrm{~cm}$ decrease to a $19 \mathrm{~cm}$ increase up to 2100 (three of the 13 stations are shown in Table 7).

The land uplift rates on the Finnish coast range from 4.1 to $9.9 \mathrm{~mm} / \mathrm{yr}$ (Table 3). These values are higher than those determined before, due to the correction made for the wind-induced effect and higher estimated large-scale sea level rise. The land uplift is weakest

\section{Table 7}

Mean wind-induced component of the sea level at different tide gauge stations; values calculated from observed geostrophic winds (1961-2000), and model-based estimates from Table 6 (2046-2065 and 2081-2100).

\begin{tabular}{|c|c|c|c|c|c|c|c|c|c|}
\hline Years & \multicolumn{3}{|c|}{ Oulu (cm) } & \multicolumn{3}{|c|}{ Degerby $(\mathrm{cm})$} & \multicolumn{3}{|c|}{ Hamina (cm) } \\
\hline \multirow[t]{2}{*}{ 1961-2000 } & \multicolumn{3}{|c|}{23} & \multicolumn{3}{|c|}{20} & \multicolumn{3}{|c|}{24} \\
\hline & A1B & Min & Max & A1B & Min & Max & A1B & Min & Max \\
\hline $2046-2065$ & 28 & 19 & 37 & 24 & 16 & 32 & 29 & 19 & 39 \\
\hline $2081-2100$ & 30 & 19 & 40 & 26 & 17 & 35 & 31 & 20 & 42 \\
\hline
\end{tabular}

\section{Table 8}

Sea level scenarios for 2100 at the Finnish tide gauge stations; "average scenario" refers to the weighted average, and low and high scenarios correspond to the $5 \%$ and $95 \%$ cumulative probabilities. Sea level change from 2000 to 2100 is given, as well as the sea level in 2100 in the N2000 height system.

\begin{tabular}{|c|c|c|c|c|c|c|}
\hline \multirow[b]{2}{*}{ Tide gauge } & \multicolumn{3}{|c|}{ Change 2000-2100 (cm) } & \multicolumn{3}{|c|}{ Sea level in 2100 (cm, N2000) } \\
\hline & Low & Average & High & Low & Average & High \\
\hline Kemi & -69 & -26 & 25 & -49 & -6 & 46 \\
\hline Oulu & -66 & -24 & 28 & -46 & -3 & 49 \\
\hline Raahe & -69 & -27 & 25 & -49 & -7 & 45 \\
\hline Pietarsaari & -70 & -28 & 24 & -51 & -9 & 43 \\
\hline Vaasa & -72 & -30 & 22 & -53 & -10 & 41 \\
\hline Kaskinen & -66 & -21 & 35 & -46 & -2 & 54 \\
\hline Mäntyluoto & -57 & -13 & 43 & -38 & 6 & 62 \\
\hline Rauma & -49 & -4 & 52 & -30 & 14 & 70 \\
\hline Turku & -36 & 9 & 65 & -17 & 27 & 83 \\
\hline Degerby & -38 & 6 & 62 & -22 & 22 & 78 \\
\hline Hanko & -22 & 24 & 82 & -3 & 42 & 100 \\
\hline Helsinki & -15 & 30 & 89 & 5 & 50 & 109 \\
\hline Hamina & -12 & 33 & 92 & 8 & 54 & 113 \\
\hline
\end{tabular}

in the Gulf of Finland and strongest around Vaasa in the Gulf of Bothnia, in accordance with several earlier assessments (Johansson et al., 2004; Lisitzin, 1964; Vermeer et al., 1988).

The land uplift rates are based on an assumption of a large-scale sea level rise of $1.7 \pm 0.5 \mathrm{~mm} / \mathrm{yr}$ on the Finnish coast. This value represents the global average sea level rise, and as the sea level rise is unevenly distributed, its applicability to the Baltic Sea can be questioned. Since the measured sea level data alone are not sufficient for determining the actual sea level rise and land uplift separately, a more accurate determination of the land uplift rates and large-scale sea level rise in the Baltic Sea might be achieved by combining the sea level studies with GPS-based crustal movement rates. Such studies have been published (Richter et al., 2011; Vestøl, 2006). Including an analysis of the meteorological effect on sea levels in such studies might further make it possible to separate the large-scale sea level rise and the meteorologically-induced sea level trends.

Several projections for the global mean sea level rise, ranging from 20 to $200 \mathrm{~cm}$ up to the end of this century, were weighted on the basis of a subjective assessment of their relevance (Table 4) and combined to form a probability distribution for the sea level rise. The combined scenario projects a global average sea level rise of $26-155 \mathrm{~cm}$ from 2000 to 2100 (5\% to 95\% probability range; Fig. 6).

The sea level rise due to ocean density and circulation changes, and melting of land-based ice is distributed unevenly over the world ocean. Around the northeastern Atlantic, the contribution of ocean density and circulation changes is expected to be larger than in the global average. On the other hand, the effect of melting of the Greenland ice sheet, and smaller glaciers and ice caps will be considerably smaller (Table 5). The highest sea level rise scenarios, in particular, contain a significant contribution from the Greenland ice sheet, which results in attenuated regional sea level rise on the Finnish coast. The large-scale sea level rise on the Finnish coast is thereby expected to be smaller than the global average (Fig. 5; Table 5). The $5 \%$ to $95 \%$ probability range is estimated to be $24-126 \mathrm{~cm}$ for the Gulf of Finland, 24-122 cm for the Bothnian Sea and 24-115 cm for the Bothnian Bay (Fig. 6).

The local relative sea level scenarios were composed by combining the land uplift, wind-induced change, and the large-scale sea level rise. In the Gulf of Finland, the land uplift is weakest and, according to the average scenario, the sea level will rise $24-33 \mathrm{~cm}$ from 2000 to 2100 , while the highest scenario predicts a $92 \mathrm{~cm}$ rise at Hamina (Table 8). In the Bothnian Bay, the strong land uplift compensates for the sea level rise. There, the average scenario predicts a decline of $24-30 \mathrm{~cm}$, while the high scenario predicts, for example, a rise of $28 \mathrm{~cm}$ at Oulu. The Bothnian Sea falls between these two extremes, with the average scenarios ranging from a $21 \mathrm{~cm}$ decline to a $9 \mathrm{~cm}$ 
a

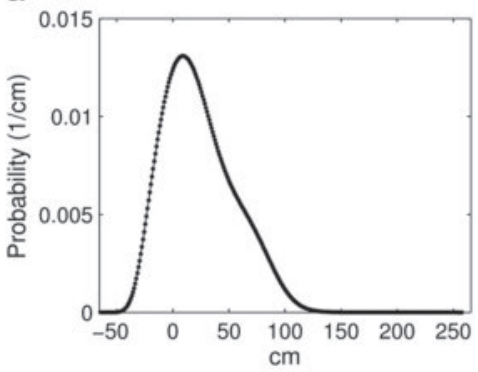

C

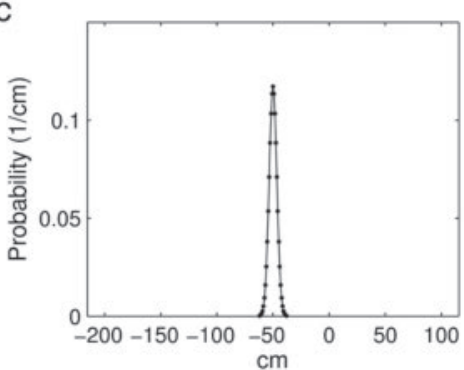

b
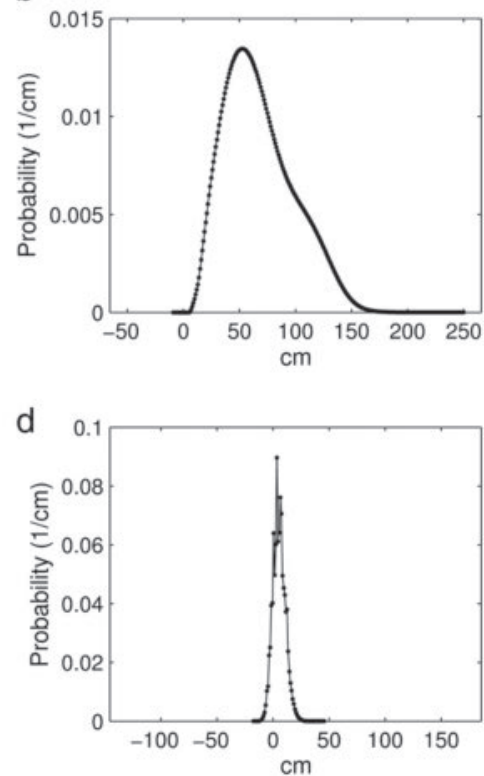

Fig. 8. a) The total probability density function for the sea level change at Hanko from 2000 to 2100 , and the contributions of individual factors affecting the sea level: b) large-scale sea level rise, c) land uplift, and d) wind-induced sea level component.

rise. Average scenario here is the weighted average, and low and high scenarios correspond to the $5 \%$ and $95 \%$ cumulative probabilities.

As we combined an ensemble of several large-scale sea level rise scenarios representing different assumptions, greenhouse gas emission and global warming scenarios, our scenarios do not represent any specific emission scenario. Instead, the scenarios can be regarded as covering a wide range of future emissions and climate changes. The extreme alternative is also accounted for; we have included the scenario of Pfeffer et al. (2008), which includes physically possible but extremely accelerated sea level rise from the ice sheets, glaciers and ice caps. This is what we have been aiming at with our method of constructing a probability distribution - the extreme cases as well as the more moderate projections should be accounted for by a single scenario range.

The sea level scenarios calculated in this study are higher than those reported in Johansson et al. (2004). For instance, the projected change from 2000 to 2100 at Hanko ranges from -22 to $+82 \mathrm{~cm}$, the average estimate being $+24 \mathrm{~cm}$. In Johansson et al. (2004), the change from 2000 to 2093 for Hanko ranged from -30 to $+37 \mathrm{~cm}$, with an average of $-4 \mathrm{~cm}$ (their Fig. 7). This difference is mainly due to a higher estimate for the large-scale sea level rise. While the scenarios of Johansson et al. (2004) were based on a large-scale sea level rise projection of 9-88 cm (Church et al., 2001), the present study utilised the estimated effect of the large-scale sea level rise of $24-126 \mathrm{~cm}$ in the Gulf of Finland.

The decision to fit Weibull distributions to the global sea level rise scenarios derived from literature, and the assumption that the low and high scenarios generally correspond to the $5 \%$ and $95 \%$ probability levels (Table 4) strongly affects the probability levels of the scenarios on the Finnish coast. The uncertainties in the sea level rise scenarios are large enough to justify an opinion that no probability distributions should be attached to the scenarios. However, in practical applications such probabilities are often demanded. For instance, to be able to assess the probability of extreme sea level events reaching a certain level in the future - a question of significant importance for coastal planning - probabilities for the different mean sea level scenarios are necessary. The somewhat subjective estimate that we have presented in this paper is our best effort to make those decisions possible. The sea level scenarios will inevitably evolve as more research is conducted, but for practical applications answers are needed now, based on the best knowledge available at the moment.

The tests for the effect of weighting and scaling of the scenarios (Section 4.4) showed that the scenarios are robust and only slightly affected by the choice of the weighting method. The scaling affects the scenarios more, but it has a physical justification as the effect on the Finnish coast of the melting of the Greenland ice sheet and smaller glaciers and ice caps is expected to be smaller than the global average.

To construct more objective scenarios for the sea level rise and to reduce the uncertainties, more research is needed. The dynamics of the large ice sheets of Greenland and Antarctica in a warming climate is not yet fully understood, and this results in large uncertainties in the global sea level rise scenarios. Also, the factors affecting the geographical distribution of the sea level rise - gravitational effects, changes in ocean dynamics etc. - should be studied in more detail to allow more precise estimates of their contribution on the Finnish coast. From a Finnish viewpoint, we should follow the progress in the studies of the global climate change and sea level rise and update the local scenarios for the Finnish coast accordingly.

\section{Acknowledgements}

The constructive criticism by an anonymous reviewer helped us to improve this paper. The DS010.0 sea-level pressure data were downloaded from the Research Data Archive (RDA) maintained by the Computational and Information Systems Laboratory (CISL) at the National Center for Atmospheric Research (NCAR). The modelling groups, the Program for Climate Model Diagnosis and Intercomparison (PCMDI), and the WCRP's Working Group on Coupled Modelling (WGCM) are acknowledged for making available the WCRP CMIP3 multimodel dataset. This study was supported financially by the Finnish Ministry of Employment and the Economy, as a part of the Finnish National Research Programme on Nuclear Power Plant Safety (SAFIR). 


\section{References}

Andersson, H.C., 2002. Influence of long-term regional and large-scale atmospheric circulation on the Baltic sea level. Tellus A 54, 76-88.

Bindoff, N.L., Willebrand, J., Artale, V., Cazenave, A., Gregory, J., Gulev, S., Hanawa, K., Le Quéré, C., Levitus, S., Nojiri, Y., Shum, C.K., Talley, L.D., Unnikrishnan, A., 2007. Observations: oceanic climate change and sea level. In: Solomon, S., et al. (Ed.), Climate Change 2007: The Physical Science Basis. Contribution of Working Group I to the Fourth Assessment Report of the Intergovernmental Panel on Climate Change. Cambridge University Press, Cambridge and New York.

Cazenave, A., Llovel, W., 2010. Contemporary sea level rise. Annu. Rev. Mar. Sci. 2, $145-173$.

Church, J.A., et al., 2001. Changes in sea level. In: Houghton, J.T., et al. (Ed.), Climate Change 2001: The Scientific Basis. Contribution of Working Group I to the Third Assessment Report of the Intergovernmental Panel on Climate Change. Cambridge University Press, Cambridge and New York, pp. 639-693.

Church, J.A., Gregory, J.M., White, N.J., Platten, S.M., Mitrovica, J.X., 2011. Understanding and projecting sea level change. Oceanography 24, 130-143.

Gregow, H., Ruosteenoja, K., Pimenoff, N., Jylhä, K., 2011. Changes in the mean and extreme geostrophic wind speeds in Northern Europe until 2100 based on nine global climate models. Int. J. Climatol. http://dx.doi.org/10.1002/joc.2398 (published online).

Grinsted, A., Moore, J.C., Jevrejeva, S., 2010. Reconstructing sea level from paleo and projected temperatures 200 to 2100 AD. Clim. Dyn. 34, 461-472.

Hansen, J.E., 2007. Scientific reticence and sea level rise. Environ. Res. Lett. 2, 024002.

Hela, I., 1953. A study of land upheaval at the Finnish coasts. Fennia 76, 1-38.

Horton, R., Herweijer, C., Rosenzweig, C., Liu, J., Gornitz, V., Ruane, A.C., 2008. Sea level rise projections for current generation CGCMs based on the semi-empirical method. Geophys. Res. Lett. 35, L02715.

Jevrejeva, S., Moore, J.C., Grinsted, A., 2010. How will sea level respond to changes in natural and anthropogenic forcings by 2100 ? Geophys. Res. Lett. 37, L07703.

Jevrejeva, S., Moore, J.C., Grinsted, A., 2012. Sea level projections to AD 2500 with a new generation of climate change scenarios. Global Planet. Change 80-81, 14-20.

Johansson, M., Boman, H., Kahma, K.K., Launiainen, J., 2001. Trends in sea level variability in the Baltic Sea. Boreal Env. Res. 6, 159-179.

Johansson, M.M., Kahma, K.K., Boman, H., 2003. An improved estimate for the longterm mean sea level on the Finnish coast. Geophysica 39, 51-73.

Johansson, M.M., Kahma, K.K., Boman, H., Launiainen, J., 2004. Scenarios for sea level on the Finnish coast. Boreal Env. Res. 9, 153-166.

Kahma, K., 1999. Atlantin ilmanpaine vaikuttaa Itämereen (NAO is reflected in the Baltic Sea level). Finn. Inst. of Mar. Res. Annu. Rep. 1999.

Katsman, C.A., Hazeleger, W., Drijfhout, S.S., van Oldenborgh, G.J., Burgers, G., 2008. Climate scenarios of sea level rise for the northeast Atlantic Ocean: a study including the effects of ocean dynamics and gravity changes induced by ice melt. Clim. Change 91, 351-374.

Katsman, C.A., Sterl, A., Beersma, J.J., van den Brink, H.W., Church, J.A., Hazeleger, W., Kopp, R.E., Kroon, D., Kwadijk, J., Lammersen, R., Lowe, J., Oppenheimer, M., Plag H.-P., Ridley, J., von Storch, H., Vaughan, D.G., Vellinga, P., Vermeersen, L.L.A., van de Wal, R.S.W., Weisse, R., 2011. Exploring high-end scenarios for local sea leve rise to develop flood protection strategies for a low-lying delta-The Netherlands as an example. Clim. Change 109, 617-645.

Lidberg, M., Johansson, J.M., Scherneck, H.-G., Davis, J.L., 2007. An improved and extended GPS-derived 3D velocity field of the glacial isostatic adjustment (GIA) in Fennoscandia. J. Geod. 8, 213-230.

Lisitzin, E., 1964. Contribution to the knowledge of land uplift along the Finnish coast. Fennia 89, 1-22.

Meehl, G.A., Stocker, T.F., Collins, W.D., Friedlingstein, P., Gaye, A.T., Gregory, J.M., Kitoh, A., Knutti, R., Murphy, J.M., Noda, A., Raper, S.C.B., Watterson, I.G., Weaver, A.J., Zhao,
Z.-C., 2007. Global climate projections. In: Solomon, S., et al. (Ed.), Climate Change 2007: The Physical Science Basis. Contribution of Working Group I to the Fourth Assessment Report of the Intergovernmental Panel on Climate Change. Cambridge University Press, Cambridge and New York.

Meier, H.E.M., Broman, B., Kjellström, E., 2004. Simulated sea level in past and future climates of the Baltic Sea. Clim. Res. 27, 59-75.

Mitrovica, J.X., Tamisiea, M.E., Davis, J.L., Milne, G.A., 2001. Recent mass balance of polar ice sheets inferred from patterns of global sea level change. Nature 409, 1026-1029.

Nakićenović, N., Alcamo, J., Davis, G., de Vries, B., Fenhann, J., Gaffin, S., Gregory, K., Grübler, A., Jung, T.Y., Kram, T., La Rovere, E.L., Michaelis, L., Mori, S., Morita, T., Pepper, W., Pitcher, H., Price, L., Riahi, K., Roehrl, A., Rogner, H.-H., Sankovski, A., Schlesinger, M., Shukla, P., Smith, S., Swart, R., van Rooijen, S., Victor, N., Dadi, Z., 2000. IPCC Special Report on Emissions Scenarios. Cambridge University Press, Cambridge and New York.

Pfeffer, W.T., Harper, J.T., O'Neel, S., 2008. Kinematic constraints on glacier contributions to 21 st-century sea-level rise. Science $321,1340-1343$.

Rahmstorf, S., 2007. A semi-empirical approach to projecting future sea-level rise. Science $315,368-370$.

Rahmstorf, S., Cazenave, A., Church, J.A., Hansen, J.E., Keeling, R.F., Parker, D.E., Somerville, R.C.J., 2007. Recent climate observations compared to projections. Science 316, 709.

Richter, A., Groh, A., Dietrich, R., in press. Geodetic observation of sea-level change and crustal deformation in the Baltic Sea region. Phys. Chem. Earth

Saaranen, V., Lehmuskoski, P., Rouhiainen, P., Takalo, M., Mäkinen, J., Poutanen, M., 2009. The new Finnish height reference N2000. October 9-14, 2006. In: Drewes, H. (Ed.), IAG Symposia, 134. Geodetic Reference Frames, Munich, Germany, pp. 297-302.

Slangen, A.B.A., Katsman, C.A., van de Wal, R.S.W., Vermeersen, L.L.A., Riva, R.E.M., 2011 Towards regional projections of twenty-first century sea-level change based on IPCC SRES scenarios. Clim. Dyn. http://dx.doi.org/10.1007/s00382-011-1057-6 (published online).

Suursaar, Ü., Sooäär, J., 2007. Decadal variations in mean and extreme sea level values along the Estonian coast of the Baltic Sea. Tellus 59A, 249-260.

Suursaar, Ü., Jaagus, J., Kullas, T., 2006. Past and future changes in sea level near the Estonian coast in relation to changes in wind climate. Boreal Env. Res. 11, 123-142.

Tamisiea, M.E., Mitrovica, J.X., Davis, J.L., Milne, G.A., 2003. Long wavelength sea level and solid surface perturbations driven by polar ice mass variations: fingerprinting Greenland and Antarctic ice sheet flux. Space Sci. Rev. 108, 81-93.

Trenberth, K.E., Paolino, D.A., 1980. The northern hemisphere sea level pressure data set: trends, errors, and discontinuities. Mon. Wea. Rev. 108, 855-872.

U.S. National Center for Atmospheric Research [CISL/Data Support Section], U.S. National Weather Service, Massachusetts Institute of Technology [Dept. of Earth, Atmospheric, and Planetary Sciences], U.K. Met Office, U.S. National Climatic Data Center, U.S. Naval Research Laboratory, and U.S. National Centers for Environmental Prediction, 2011. Daily Northern Hemisphere Sea Level Pressure Grids, continuing from 1899. Dataset ds010.0 published by the CISL Data Support Section at the National Center for Atmospheric Research, Boulder, CO, available online at http://dss.ucar. edu/datasets/ds010.0/.

Vermeer, M., Rahmstorf, S., 2009. Global sea level linked to global temperature. PNAS 106, 21527-21532.

Vermeer, M., Kakkuri, J., Mälkki, P., Boman, H., Kahma, K.K., Leppäranta, M., 1988. Land uplift and sea level variability spectrum using fully measured monthly means of tide gauge readings. Finn. Mar. Res. 256, 1-75.

Vestøl, O., 2006. Determination of postglacial land uplift in Fennoscandia from leveling tide-gauges and continuous GPS stations using least squares collocation. J. Geod. $80,248-258$ 
(C)2014 Springer Nature

Reprinted, with kind permission, from Natural Hazards, 74, 197-215 doi: 10.1007/s11069-014-1150-3 



\title{
Recent observations of meteotsunamis on the Finnish coast
}

\author{
Hilkka Pellikka • Jenni Rauhala • Kimmo K. Kahma • Tapani Stipa • \\ Hanna Boman • Antti Kangas
}

Received: 3 December 2013/Accepted: 14 March 2014/Published online: 27 March 2014

(C) Springer Science+Business Media Dordrecht 2014

\begin{abstract}
We present four case studies of exceptional wave events of meteorological origin, observed on the Finnish coast in the summers of 2010 and 2011. Eyewitnesses report unusually rapid and strong sea-level variations (up to $1 \mathrm{~m}$ in 5-15 min) and strong oscillating currents during these events. High-resolution sea-level measurements confirm the eyewitness observations, but the oscillations recorded by tide gauges mostly have a considerably smaller amplitude. The oscillations coincide with sudden jumps in surface air pressure at coastal observation stations, related to the passage of squall lines or gust fronts. These fronts propagate above the sea at a resonant speed, allowing efficient energy transfer between the atmospheric disturbance and the sea wave that it generates. Thus, we interpret the observed sea-level oscillations as small meteotsunamis, long tsunami-like waves generated by meteorological processes and resonance effects.
\end{abstract}

Keywords Meteotsunami $\cdot$ Sea-level variations $\cdot$ Tide-gauge records $\cdot$ Baltic Sea $\cdot$ Gulf of Finland · Gulf of Bothnia

\section{Introduction}

In July and August 2010, the Marine Research unit at the Finnish Meteorological Institute (FMI) received several phone calls and emails about unusually strong and rapid sea-level oscillations, observed at different locations along the Finnish coast. The eyewitnesses described the events as exceptional and impressive: the sea-level rose and fell up to $1 \mathrm{~m}$ in 5-15 min and caused strong currents in shallow straits. No such reports had been received by the sea-level researchers at the FMI at least since the beginning of the 1970s, but there are historical occurrences of such events on the Finnish coast (e.g. Renqvist 1926a).

H. Pellikka ( $($ ) · J. Rauhala · K. K. Kahma · T. Stipa · H. Boman · A. Kangas Finnish Meteorological Institute, P.O. Box 503, FI-00101 Helsinki, Finland e-mail: hilkka.pellikka@fmi.fi 
The oscillations were soon found to coincide with sudden jumps in air pressure, caused by a gust front or squall line propagating northwards over the Gulf of Finland, or northeastwards along the Gulf of Bothnia (Fig. 1), suggesting a causal relationship. They were interpreted as small meteotsunamis, tsunami-like waves generated by atmospheric processes. In the following summer 2011, a similar event was reported.

Meteotsunamis or meteorological tsunamis are long waves in the tsunami frequency band caused by mesoscale atmospheric disturbances, such as thunderstorms, squall lines, and other air pressure anomalies, moving above the sea at a resonant speed (Monserrat et al. 2006). These waves occur more or less regularly in certain areas of the world ocean, where conditions favour their formation, and in extreme cases, they can reach destructive dimensions. The formation of a strong meteotsunami requires resonance between the moving atmospheric disturbance and the long sea wave that it generates. In addition, just as in the case of seismic tsunamis, topographically controlled effects such as shoaling, focusing by refraction, and harbour resonance are required to amplify the small open sea waves into sizeable waves at the shoreline.

In theory, the shallow bathymetry (mean depth $55 \mathrm{~m}$ ) and complex coastline of the Baltic Sea make it vulnerable to the formation of meteotsunamis. The phenomenon has indeed long been known among the coastal residents of the Baltic Sea, and there is anecdotal evidence, both old and contemporary, from seafarers of encounters with the phenomenon. This type of unexpected and inexplicable high wave is known on the Swedish and Finnish coasts under the Swedish name sjösprång ("sea jump") and on the southern Baltic coast under the German name Seebär (literally "sea bear", but the word derives from an old word Bahre, meaning wave; Renqvist 1926b). While older scientific literature includes many references to historical Baltic meteotsunamis (e.g. Credner 1889; Doss 1907; Renqvist 1926a, b; Defant 1961), modern analyses are largely lacking.

Fig. 1 Map of the study area: the coast of Finland on the Baltic Sea. Colours show the bathymetry converted to long wave phase speed $\sqrt{g h}$, where $g$ is $9.82 \mathrm{~ms}^{-2}$ and $h$ is water depth. Air pressure disturbances whose velocity corresponds to the long wave speed can generate meteotsunamis. Triangles mark the locations of the Finnish tide gauges: $K E$ Kemi, $O U$ Oulu, $R A A$ Raahe, PI Pietarsaari, VA Vaasa, $K A$ Kaskinen, $M \ddot{A}$ Mäntyluoto, $R A U$ Rauma, $T U$ Turku, $D E$ Degerby, HAN Hanko, $H E$ Helsinki, HAM Hamina. The rectangle marks the location of the map in Fig. $2 d$

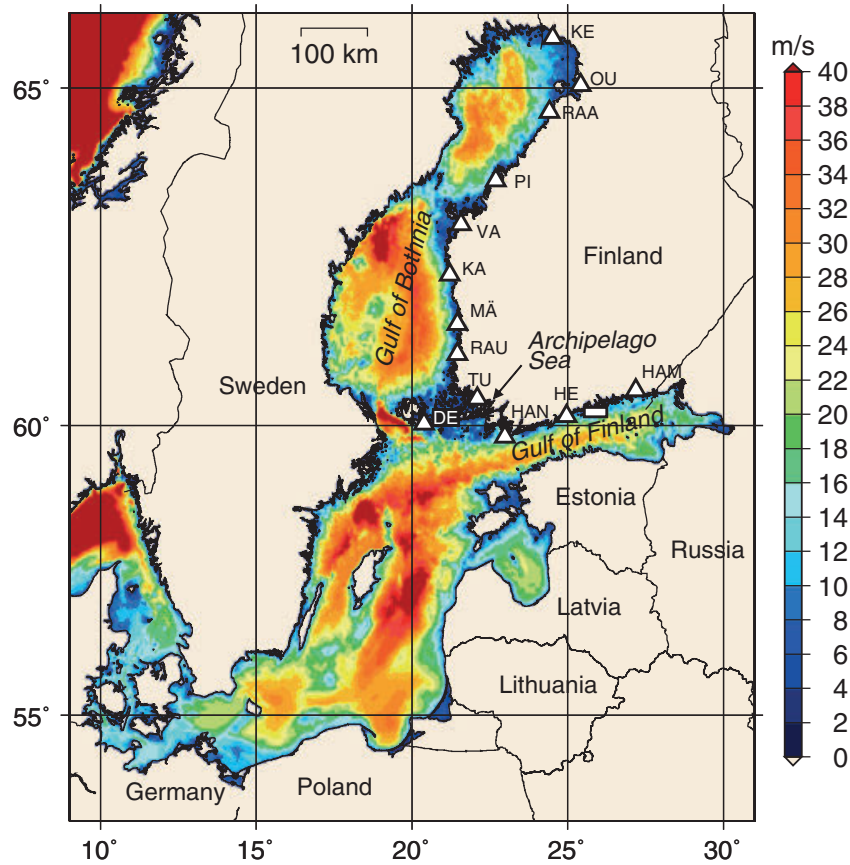


Renqvist (1926a, b) reports one meteotsunami event from 15 May 1924, observed widely on the northern coast of the Gulf of Finland. Strong currents and sea-level oscillations up to $1.5 \mathrm{~m}$ high were reported, generally during calm weather, but thunder was reported together with the waves at two observation sites and later in the evening at other locations. Renqvist suggests that whirlwinds and waterspouts would be the most probable explanation for the phenomenon, even though waterspouts were not observed.

The name Seebär is also used in historical descriptions of very strong, highly destructive waves observed on the southern Baltic coast, e.g. in Darłowo in 1497 and the mouth of the Rega river in 1757, capable of carrying ships deep inland (Piotrowski et al. 2013). These waves have been reported to occur both under clear and calm weather and during storms, sometimes accompanied by a sound resembling thunder, which refers to meteorological origin. The origin of the waves is unknown, but as the seismic activity of the region is low, it seems unlikely that these waves could have been of seismic origin (Pekka Heikkinen, private communication 2011), although tectonical causes and underwater methane explosions have been proposed by some authors (Piotrowski et al. 2013).

We present case studies of the recent small meteotsunamis observed on the Finnish coast in 2010 and 2011 by combining marine and meteorological observations, including radar imagery. The study is motivated by two main issues: (1) the lack of modern scientific knowledge regarding Baltic meteotsunamis and (2) the risks they pose to maritime and coastal activities. Although the observed oscillations did not cause significant damage, bottom contact with some damage to a vessel did occur. Strong unexpected currents or sudden lack of water under the keel of a boat can cause hazardous situations in coastal traffic. In addition, it should be noted that the water level in the Baltic Sea can be well above average for a prolonged time due to wind conditions that regulate water exchange in the Danish straits (Johansson et al. 2014). If a meteotsunami would occur during such a situation, record sea levels could be exceeded, e.g. in the Archipelago Sea, where sea-level variations are relatively small. The occurrence of meteotsunamis should be taken into account in risk analyses made for coastal activities, e.g. the safety of the Finnish nuclear power plants. Better understanding of the phenomenon serves this purpose.

\section{Essential features of meteotsunamis}

Meteorological phenomena cause sea-level fluctuations at various scales, from seconds to days or longer in time, from small wind-driven surface waves to seiches and storm surges. Thus, defining a meteotsunami and distinguishing it from other sea-level oscillations is not a trivial task. Meteotsunamis have physical dimensions similar to seismic tsunamis: periods ranging from minutes up to $2 \mathrm{~h}$ and wavelengths from kilometres to hundreds of kilometres. A height criterion is needed to distinguish meteotsunamis from background noise. One definition proposed for a meteotsunami is a wave height three or four times the standard deviation of the sea-level variation at the location (Monserrat et al. 2006). However, the height of a meteotsunami strongly depends on local topography, and high oscillations may not be observed at the points where water-level measurements take place.

In the semi-enclosed Baltic Sea and its sub-basins, seiches (internal eigenoscillations, or standing waves inside a basin) are a typical phenomenon. The seiche period depends on the length and depth of the basin and the number of nodes in the standing wave; in the Baltic Sea, the characteristic periods are several hours or longer, up to $26 \mathrm{~h}$ (Lisitzin 1959). In the smaller sub-basins, however, seiches may have periods similar to meteotsunami waves. 
Basin-wide seiches and meteotsunamis are different phenomena with different generation mechanisms, and we must be able to distinguish them from each other.

The essential feature of a meteotsunami is its formation process: the initially small wave grows through various resonance mechanisms, first through air-sea interaction on the open sea and then through topographically controlled amplification when the waves reach the coastline. The most common resonance mechanisms giving birth to meteotsunamis include the Proudman resonance: when the air pressure disturbance travels at a velocity close to the long wave speed in the sea $(\sqrt{g h}$, where $g$ is the acceleration due to gravity and $h$ is water depth), the disturbance can continuously feed energy to the wave that it generates (Proudman 1929). In this paper, we regard the observed sea-level oscillations as meteotsunamis, if they have characteristic temporal and spatial scales and if we can show that they were generated by atmospheric disturbances through resonance mechanisms.

Hibiya and Kajiura (1982) formulate the following equation for estimating the wave amplification due to Proudman resonance:

$$
\Delta \eta=\left(\frac{\Delta p}{\rho g}\right)\left(\frac{x_{f}}{2 L}\right)
$$

where $\Delta \eta$ is maximum wave height, $\Delta p /(\rho g)$ is the initial wave height due to the inverted barometer effect alone ( $\Delta p$ is the amplitude of the air pressure disturbance, $\rho$ the density of water, and $g$ the acceleration due to gravity), $x_{f}$ is the distance travelled by the pressure anomaly above the sea, and $L$ is the distance between the front of the disturbance and the disturbance maximum, characterising the "abruptness" of the pressure anomaly.

As the wave propagates to the shore, it is further amplified by refraction, shoaling, shoreline geometry, and harbour resonance. The shoaling amplification can be approximated by Green's law

$$
\Delta \eta_{s}=\Delta \eta_{0} \sqrt{\frac{c_{g 0}}{c_{g}}}=\Delta \eta_{0}\left(\frac{h_{0}}{h}\right)^{\frac{1}{4}}
$$

where $c_{g}=\sqrt{g h}$ is the group velocity of shallow water waves (long waves), and the subscript 0 refers to initial conditions in deep water before shoaling takes place. The approximation is reasonable as long as the wave is not close to breaking.

The formation of a strong meteotsunami requires a combination of several factors, which is why they are rare. The speed and route of the air pressure disturbance are crucial factors. Mesoscale atmospheric disturbances have typical velocities of 20-40 m/s, corresponding to the long wave speed in sea areas 40-160 m deep (Monserrat et al. 2006). However, Proudman resonance alone cannot generate destructive meteotsunamis on an open coastline. Violent oscillations are restricted to semi-enclosed basins, such as bays or harbours, where self-amplifying wave interference (harbour resonance) can occur.

The coastline of Finland (Fig. 1) is characterised by a shallow and complex topography: in the south, the Gulf of Finland with a mean depth of $37 \mathrm{~m}$ and a highly irregular northern coast; in the southwest, the shallow Archipelago Sea with a complex mosaic of islands and a mean depth of only $19 \mathrm{~m}$; and in the west, the Gulf of Bothnia with a mean depth of $55 \mathrm{~m}$ and an asymmetric bottom topography, gentler slopes being on the eastern (Finnish) side (Leppäranta and Myrberg 2009). Thus, the necessary prerequisite for the formation of meteotsunamis, namely a shallow sea area with an irregular coastline, is fulfilled. 


\section{Data and methods}

Our observational material consists of the regular weather and sea-level observations produced by the FMI together with radar data and eyewitness reports. All bathymetry data utilised in this study are from Seifert et al. (2001) and have a spatial resolution of $1^{\prime} \times 2^{\prime}$ (ca. 1 nautical mile).

\subsection{Sea-level and weather observations}

Several individuals observed unexpectedly rapid and strong sea-level variations in different parts of the Finnish coastline on 29 July 2010, 8 August 2010, and 4 June 2011. The first reports came spontaneously. After this, a specific request for such observations was made in a press release published by the FMI, and some media coverage followed.

The FMI operates 13 tide gauges on the Finnish coast (Fig. 1). For 2010-2011, the quality-controlled sea-level database consists of hourly observations, but digital data stored every minute are available for all stations. For all the meteotsunami cases we examined, the digital 1-min sea-level observations were quality controlled for this study.

Observations of the relevant meteorological parameters (surface air pressure, temperature, dewpoint, wind, and weather) during the meteotsunami events were obtained from the climate database of the FMI. Surface observation maps were produced for a better understanding of the air pressure perturbation movement in the studied cases. The surface isobar analyses were done manually by using surface observations.

\subsection{Radar data}

Data from the Finnish Meteorological Institute's C-band Doppler radars are used in this study. Radar data for the three dates are available from all FMI radars. Suitable imagery was produced from the archived raw data in order to examine the propagation speed of the atmospheric disturbances. The propagation speed of the disturbances was measured based on the location of the leading line of the radar reflectivity echoes as they move over the sea. CAPPI (Constant Altitude Plan Position Indicator) composite reflectivity images and the positions of the leading line are shown in the case studies to visualise the perturbation movements.

\section{Results}

The eyewitness observations received regarding the meteotsunami events are summarised in Table 1. A seismic origin for the waves can be excluded, as there were no earthquakes in the Baltic Sea region on the dates of the events (Institute of Seismology 2013).

\subsection{The meteotsunami of 29 July 2010}

Five eyewitness reports from three coastal islands on the northern coast of the Gulf of Finland were received concerning the event on 29 July 2010 (Table 1). According to the reports, the phenomenon was observed also in other places in the same area. The exceptional wave phenomenon occurred approximately at the same time on each island, between 05:00 and 06:00 UTC (08:00-09:00 local time). According to the eyewitness reports, 


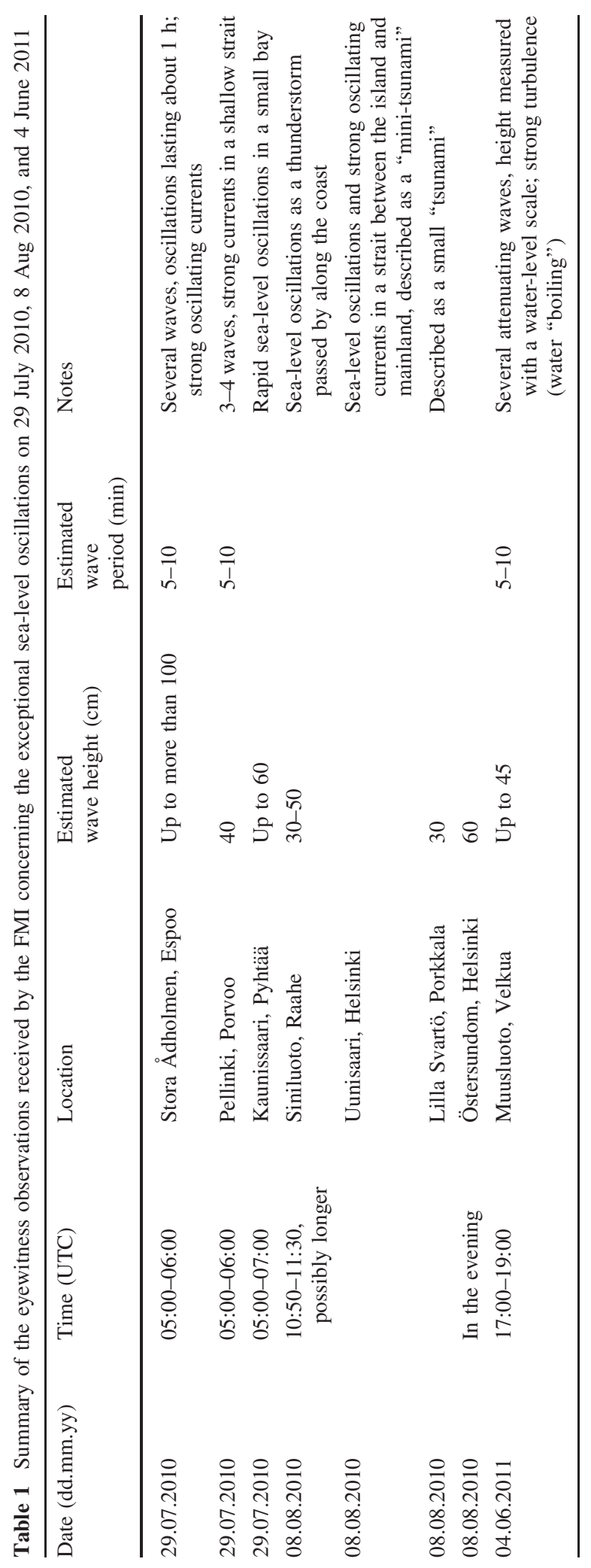



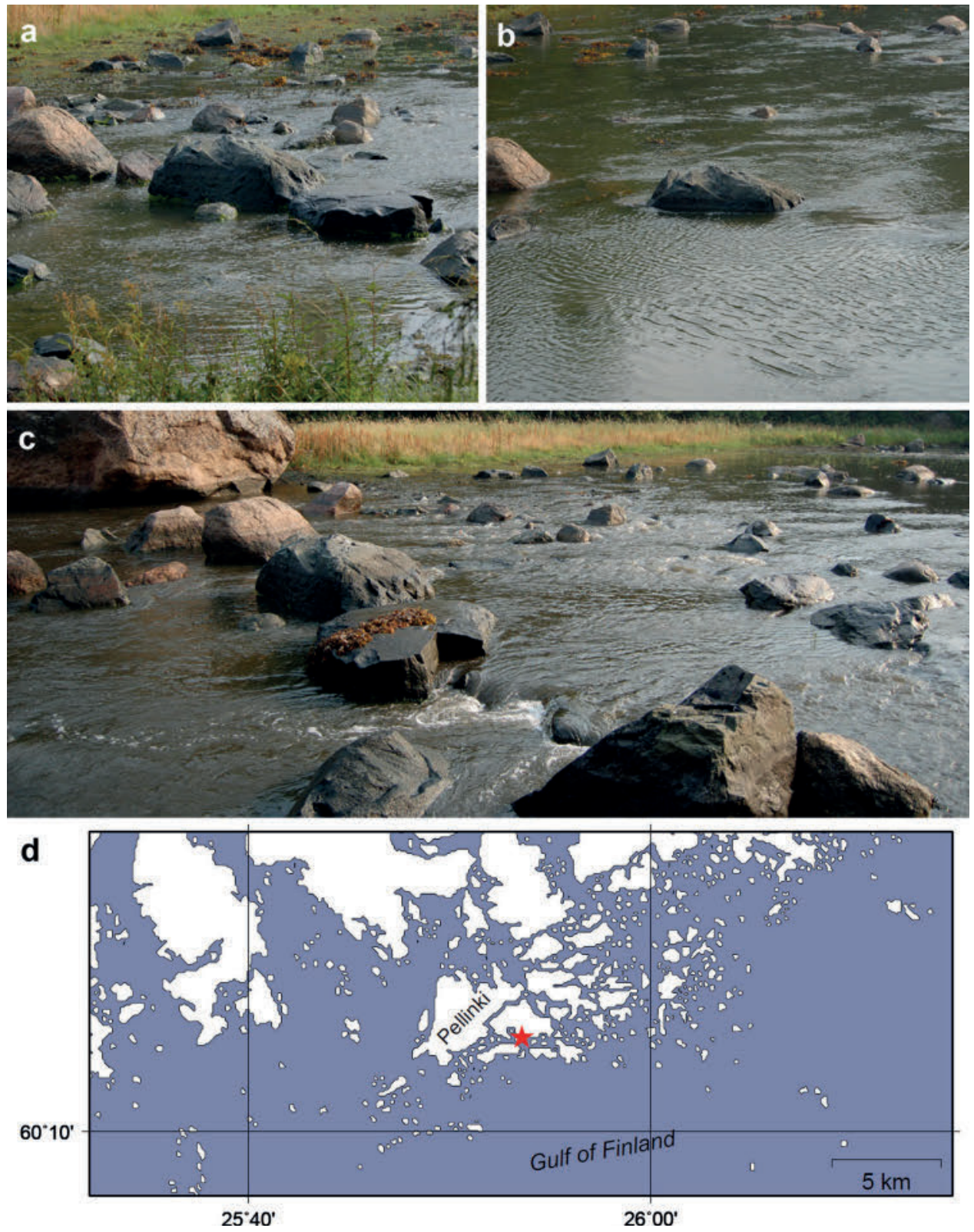

Fig. 2 a, b Two images taken at the same spot on 29 July 2010 with a 2.5 min time interval, showing the rapid sea-level fluctuation in a shallow strait. c Currents induced by sea-level oscillations in the strait. d Map of the location (Pellinki, in Porvoo archipelago, Gulf of Finland); the red star denotes the observation site. The rectangle in Fig. 1 shows the location of the map on the coastline. Photos: Dag Wallgren, used with permission

which also include photographs (Fig. 2), strong currents were formed in shallow straits, changing direction several times as the sea-level rose and fell. One eyewitness describes the events as follows: 
The water had risen dramatically, nearly one metre in $15 \mathrm{~min}$ at our shore. [...] Next the water started to flow out powerfully between the island and [a nearby islet], foaming like a rapids. In front of my eyes, the water fell below normal water level. After a few minutes, the stream turned back towards the bay [...] I saw our neighbour in his yard and shouted: 'Come see this spectacle!'. He ran onto the deck of his boat as the water again changed direction. After a moment he shouted that the boat is not floating anymore. Normally there is one metre of water under the boat. The water in the bay turned black, as the current tore up everything from the bottom. (Stora Ådholmen)

The sea-level observations at the tide gauges of Helsinki and Hamina are shown in Fig. 3a. The exceptional wave phenomenon is seen as rapid oscillations starting shortly before 05:30 UTC, corresponding well to the times given in the eyewitness reports. The amplitude of the oscillations is considerably smaller, however, probably because the topographically controlled wave amplification is weaker at the tide-gauge locations. The wave height is $10 \mathrm{~cm}$ in Helsinki and $14 \mathrm{~cm}$ in Hamina, and the periods $15-25 \mathrm{~min}$.

In the coastal surface air pressure data (Fig. 3b), the meteotsunami event coincides with a pressure jump of 1-2 $\mathrm{hPa}$ offshore of Helsinki and ca. $1 \mathrm{hPa}$ in Kotka, near Hamina. The phenomenon is restricted to the eastern part of the Gulf of Finland: the neighbouring tide gauge in Hanko, over $100 \mathrm{~km}$ west from Helsinki (1 in Fig. 4), shows small rapid oscillations somewhat later at 06:00-07:00 UTC, but no air pressure jump was observed (not shown).
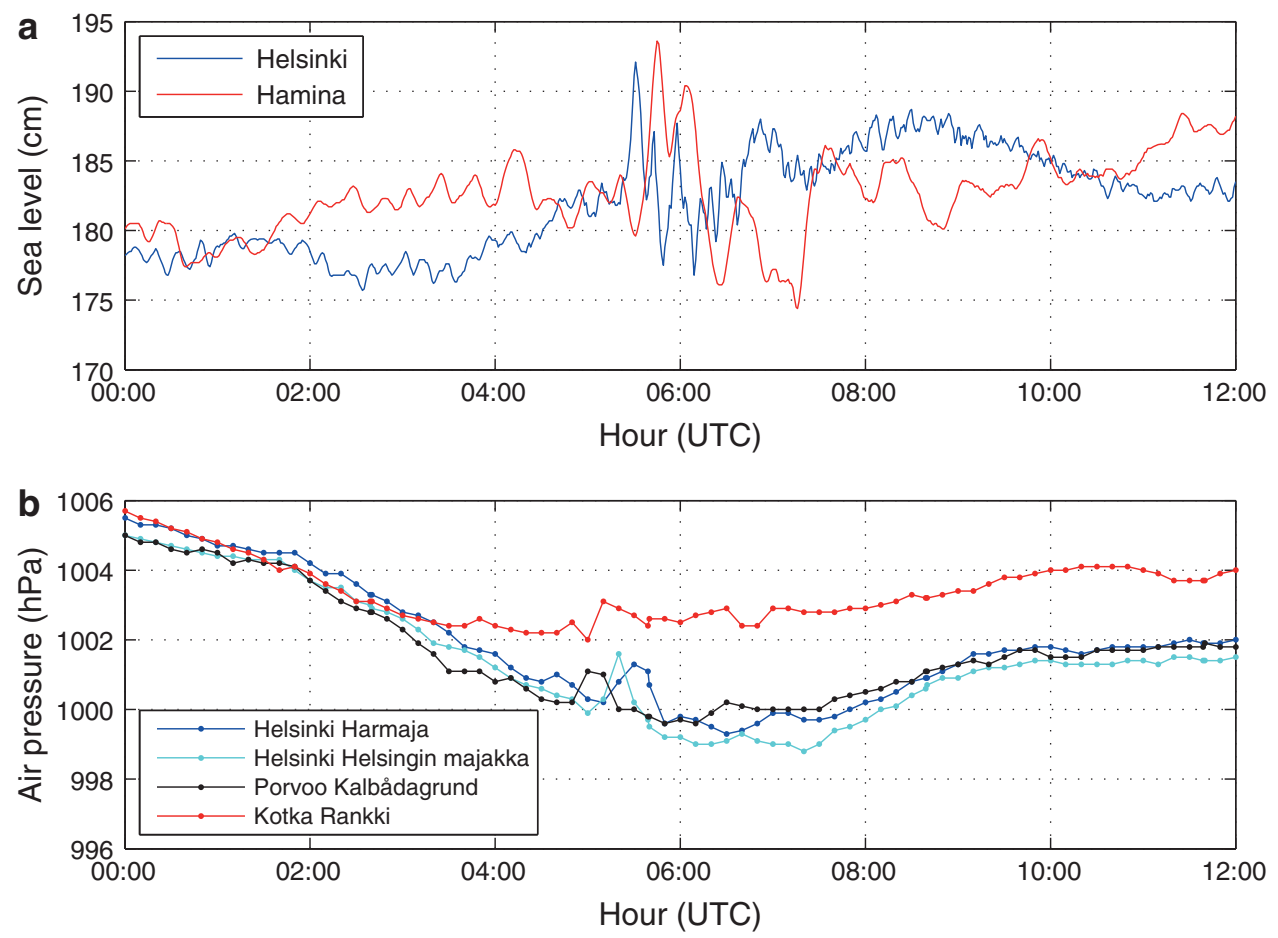

Fig. 3 a One-minute sea-level observations at the tide gauges of Helsinki and Hamina during the meteotsunami event of 29 July 2010. The reference level is the tide gauge zero. b Ten-minute sea-level pressure observations at nearby coastal stations (locations marked in Fig. 4) 


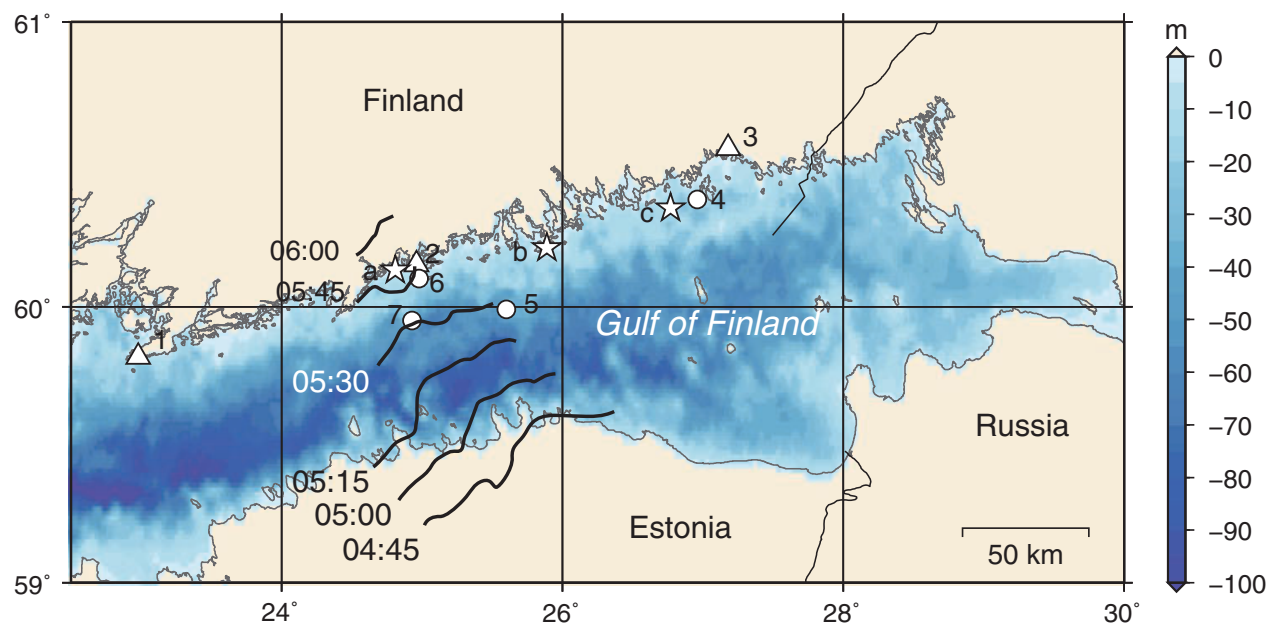

Fig. 4 Gust front propagation over the Gulf of Finland on 29 July 2010. Black lines mark the position of the leading line of the gust front (times UTC). Bathymetry of the gulf is shown in colours with depth in $m$. Stars denote the locations of eyewitness observations ( $a$ Stora Adholmen, $b$ Pellinki, $c$ Kaunissaari). Other symbols denote the locations of observation stations: triangles are tide gauges (1 Hanko, 2 Helsinki, 3 Hamina) and circles meteorological stations (4 Kotka Rankki, 5 Porvoo Kalbådagrund, 6 Helsinki Harmaja, 7 Helsinki Helsingin majakka)

During the previous night, a cluster of convective showers moved northwest over Estonia. The northern part of the cluster dissipated and separated from the southern convective cells. The remnants of the dissipating showers formed a gust front that moved fast towards the northwest over the Gulf of Finland. The gust front was visible in radar pictures as a narrow line of weak radar reflectivities, which over the Gulf of Finland consisted of convective clouds and weak rain showers (Fig. 5). The leading line of the front reached the coast at 05:45 UTC near Helsinki (Fig. 4), about 20 min after the sea-level oscillations started at the Helsinki tide gauge and 35 min after the pressure jump. Although the surface pressure perturbation extended from Helsinki up to Hamina, the gust front was not visible there.

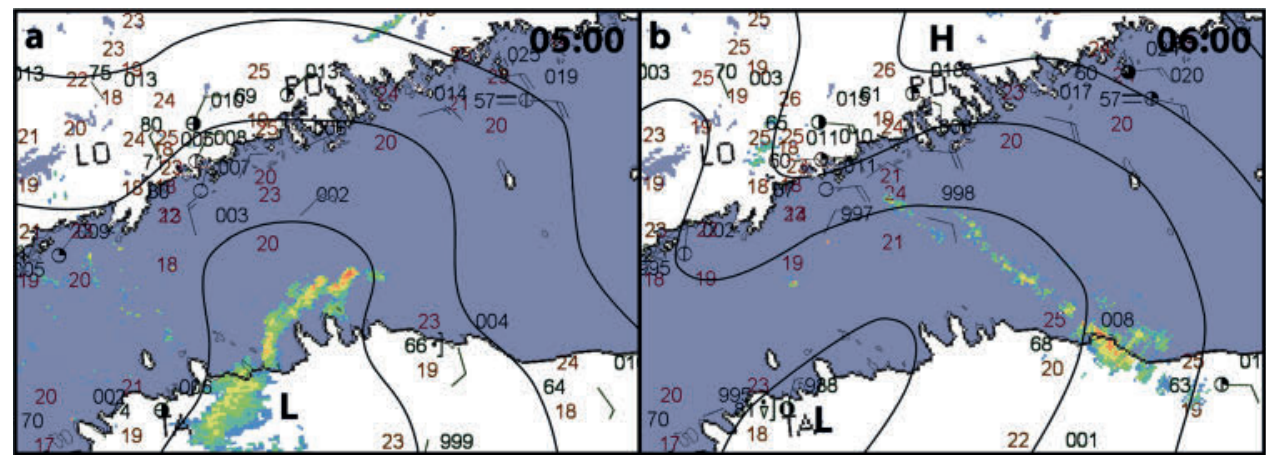

Fig. 5 Movement of a gust front and surface pressure perturbation over the Gulf of Finland on 29 July 2010 at a 05:00 and b 06:00 UTC. Temperatures, dewpoints, winds, surface pressure, and weather are plotted at station locations and overlaid on CAPPI composite reflectivity images. Surface analysis-isobars and surface lows (L) and highs $(\mathrm{H})$ - is done manually 
The speed of the gust front was rather constant over the Gulf of Finland, with a mean speed of ca. $80 \mathrm{~km} / \mathrm{h}(22 \mathrm{~m} / \mathrm{s})$. This corresponds to the long wave phase speed at a depth of $50 \mathrm{~m}$. Along the track of the front, there is a plateau $20 \mathrm{~km}$ long with a depth of 40-60 m, where Proudman resonance can occur (Fig. 4). The insufficient temporal resolution of the air pressure data does not allow us to estimate the spatial length scale $L$ in Eq. 1 accurately, but a rough estimate is between 13 and $26 \mathrm{~km}$, depending on the exact time of the pressure maximum. From Eq. 1, we see that Proudman resonance only amplifies the wave when the distance $x_{f}$ exceeds $2 L$. This suggests that amplification due to Proudman resonance has not been significant in this case.

The pressure maximum may have occurred between the sampling times and could be larger than 1 or $2 \mathrm{hPa}$, as in the similar case on 8 August 2010, when it was over $3 \mathrm{hPa}$ (Sect. 4.2.1). If we assume an upper limit of $4 \mathrm{hPa}$, the pressure jump corresponds to an initial wave height of at most $4 \mathrm{~cm}$ due to the inverted barometer effect alone. Shoaling would amplify this wave to $8 \mathrm{~cm}$ (Eq. 2), as the water depth at the tide gauges is about $2 \mathrm{~m}$. Thus, even if the pressure jump had been stronger than revealed by the 10-min observations, Proudman resonance and shoaling at the tide-gauge depth cannot explain the high sea-level oscillations. Amplification effects controlled by local topography must have been dominating, as the oscillations observed at the tide gauges are only $10-15 \mathrm{~cm}$ while oscillations of over $1 \mathrm{~m}$ were reported by eyewitnesses. Modelling work would be required to determine the exact amplification mechanisms.

\subsection{The meteotsunami of 8 August 2010}

During 8 August 2010, two separate cases occurred, one in the Gulf of Finland and the other in the Gulf of Bothnia, seen in both sea-level and meteorological data.

\subsubsection{Gulf of Finland}

Exceptional sea-level variations of up to $60 \mathrm{~cm}$ and strong oscillating currents were observed by eyewitnesses at three locations in and near Helsinki (Table 1). Indeed, sudden sea-level peaks are observed at Helsinki and Hamina tide gauges in the evening, starting at 18:10 and 18:45 UTC, respectively (Fig. 6a). The range of sea-level variation between 18:00 and 20:00 UTC is $29 \mathrm{~cm}$ in Helsinki and $44 \mathrm{~cm}$ in Hamina, whereas at the neighbouring tide gauge in Hanko (1 in Fig. 7), no similar sea-level oscillation is seen.

On 8 August 2010, convective storms formed over Belarus and Lithuania around midday and moved northwards. Over Latvia, they organised into a squall line that moved rapidly over Estonia to the Gulf of Finland (Figs. 7, 8). In Latvia, Estonia, and Finland, extensive wind damage was reported, and wind gusts of up to $36.5 \mathrm{~m} / \mathrm{s}$ were measured (Törmä et al. 2013). During the time of the damage, the squall line was of trailing stratiform type, where intense convective cells are situated in the leading line of the convective system. Destructive wind gusts occurred in the leading line of the system.

The leading line of the squall line reached Helsinki at 18:15 UTC (Fig. 7). Shortly thereafter, the peak sea-level height was measured in Helsinki, as the maximum radar reflectivities passed the area. In Hamina, in the eastern Gulf of Finland, the maximum sea level was measured at 19:07 UTC. During this time, there were no strong reflectivity echoes passing the area, but a jump in air pressure was observed even eastwards from the squall line.

The event is very clearly seen in the coastal observations of surface air pressure (Fig. 6b). In Kalbådagrund, $30 \mathrm{~km}$ from the coast, the squall line passage is seen as a sharp 

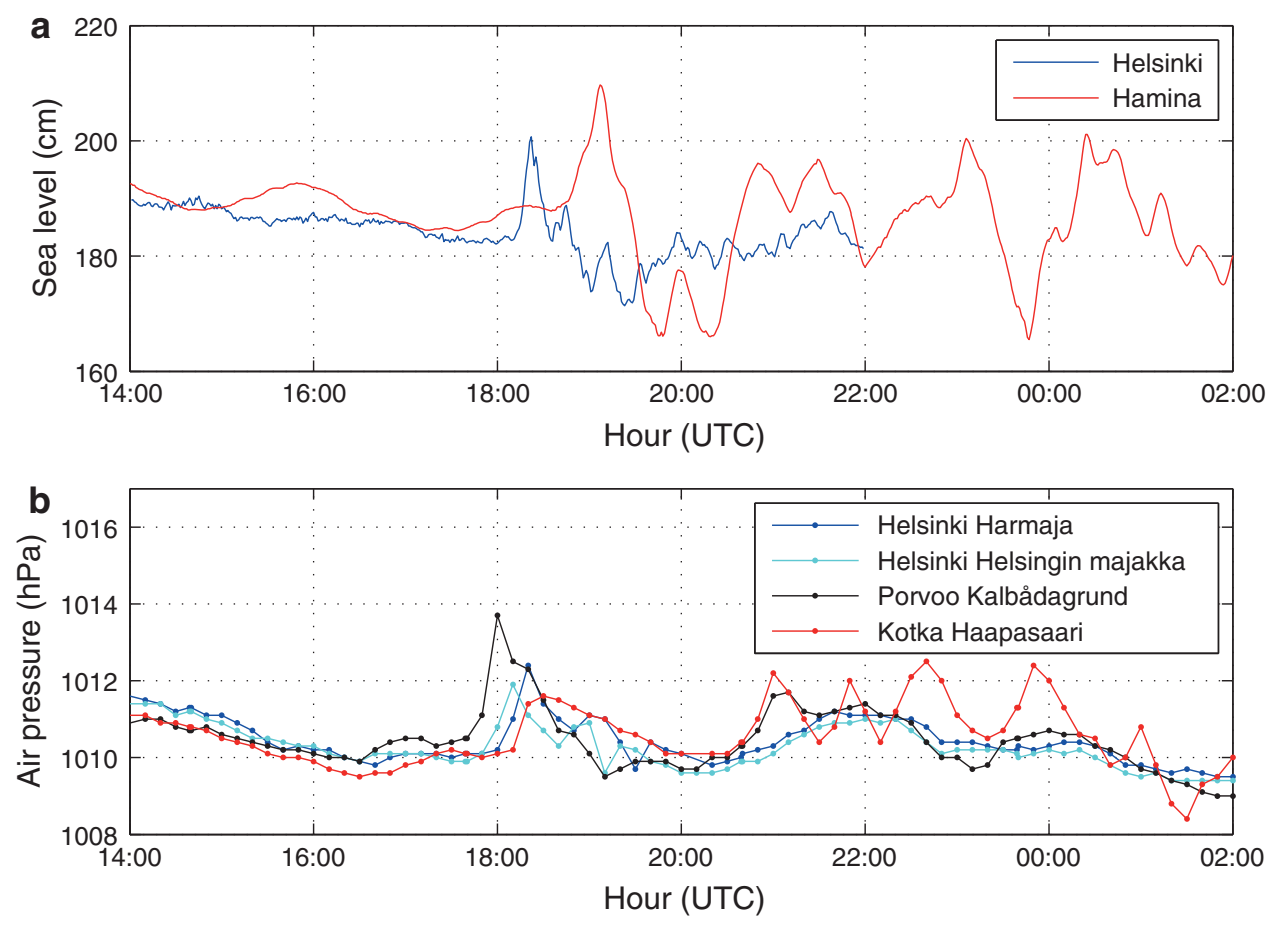

Fig. 6 a One-minute sea-level observations at the tide gauges of Helsinki and Hamina during the meteotsunami event of 8 August 2010. The reference level is the tide gauge zero. b Ten-minute sea-level pressure observations at nearby coastal stations (locations marked in Fig. 7)

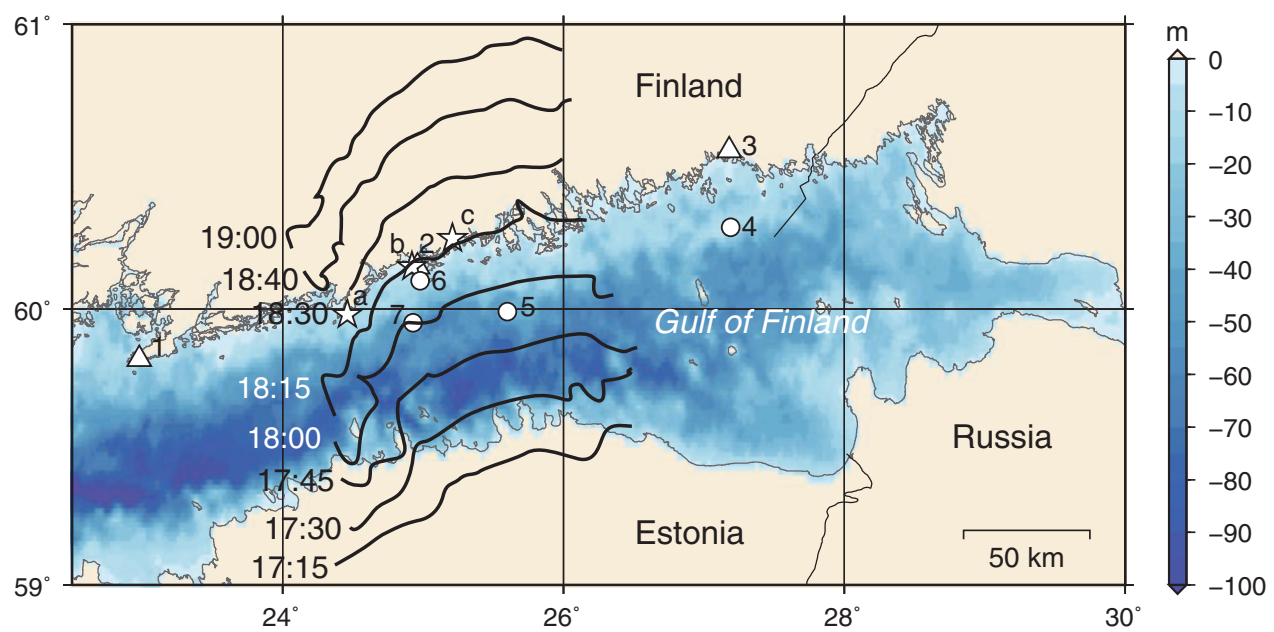

Fig. 7 Squall line propagation over the Gulf of Finland on 8 August 2010. Black lines mark the position of the leading line of the squall line (times UTC). Bathymetry of the gulf is shown in colours with depth in $m$. Stars denote the locations of eyewitness observations ( $a$ Porkkala, $b$ Uunisaari, $c$ Östersundom). Other symbols denote the locations of observation stations: triangles are tide gauges (1 Hanko, 2 Helsinki, 3 Hamina) and circles meteorological stations (4 Kotka Haapasaari, 5 Porvoo Kalbådagrund, 6 Helsinki Harmaja, 7 Helsinki Helsingin majakka) 

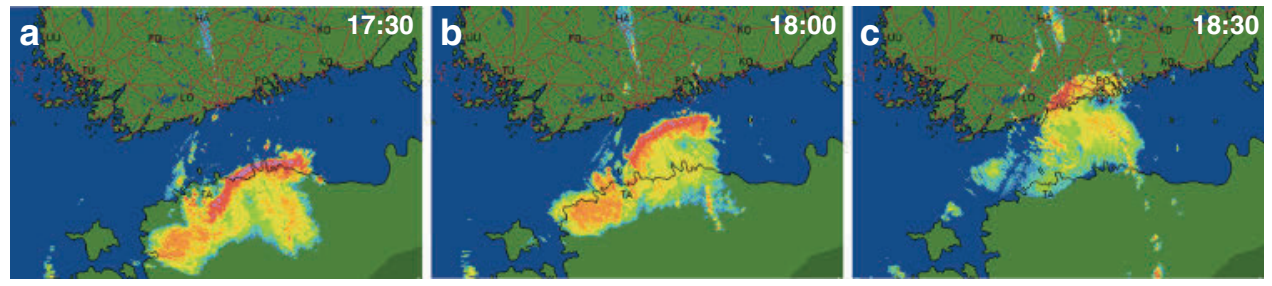

Fig. 8 CAPPI composite reflectivity images of squall line movement over the Gulf of Finland on 8 August 2010 at a 17:30, b 18:00 and c 18:30 UTC

pressure jump of $3.2 \mathrm{hPa}$. In Helsinki, the jump has a height of $2-2.5 \mathrm{hPa}$ and arrives at 18:00 UTC, shortly before the sea-level oscillations. Neither the pressure jump nor sealevel oscillations are seen in Hanko, west of Helsinki (not shown).

The speed of the squall line as it propagated over the Gulf of Finland was rather constant, ca. $86 \mathrm{~km} / \mathrm{h}(24 \mathrm{~m} / \mathrm{s})$. This corresponds to the long wave speed at a depth of $58 \mathrm{~m}$. This case resembles very much that of 29 July 2010, and similar conclusions apply. The distance over which Proudman resonance can act is rather short, and even though the pressure jump is stronger in this case, Eq. 1 suggests that the amplification factor caused by Proudman resonance alone is not significant.

We do not have eyewitness reports of high $(1 \mathrm{~m})$ sea-level oscillations in the Gulf of Finland on 8 August 2010, but at the tide gauges, the oscillations were stronger than during the 29 July 2010 event. Possibly there have been higher oscillations in topographically vulnerable places, as the phenomenon affected a wide stretch of the coast.

\subsubsection{Gulf of Bothnia}

In Siniluoto, Raahe, sea-level oscillations of up to $50 \mathrm{~cm}$ were observed by eyewitnesses in the afternoon (ca. 11:00 UTC) as a thunderstorm passed by along the coast (Table 1). In the sea-level data from the Raahe tide gauge, a single pronounced peak with a height of $54 \mathrm{~cm}$ is seen at 10:50 UTC, confirming the eyewitness report (Fig. 9a). Sea-level variations at other tide gauges in the Gulf of Bothnia show no clear peaks. In Kemi, at the head of the gulf, rapid sea-level oscillations with a maximum height of $30 \mathrm{~cm}$ were measured after 12:00 UTC, coinciding with a sudden drop in air pressure. Tide gauges in Vaasa, Pietarsaari, and Oulu (1, 2 and 4 in Fig. 10) show slower sea-level oscillations with a height of up to $0.5 \mathrm{~m}$, but with a period of $2 \mathrm{~h}$ or more.

Convective storms formed over southern Gulf of Bothnia in the early morning hours and started to move northeast. The storms became organised into a line structure, and when they reached the Finnish coast at around 05:00 UTC, the system was a leading stratiform squall line (Morrison and Thompson 2008). As the squall line moved north along the Finnish coast, it became less organised and embedded in stratiform rain. Later the mesoscale convective system (Fritsch and Forbes 2001) became again more linear in structure, and after 07:00 UTC, when the storm was approaching Kokkola from the southwest, the storm intensified and became a trailing stratiform squall line.

As the squall line moved further northeast along the coast, it became stronger and had a more asymmetric structure, with stratiform rain more around the northern parts of the squall line (Fig. 11). The leading line of the squall line reached Raahe at 10:45 UTC (Fig. 10), a few minutes before the peak sea level was observed at the local tide gauge. In 

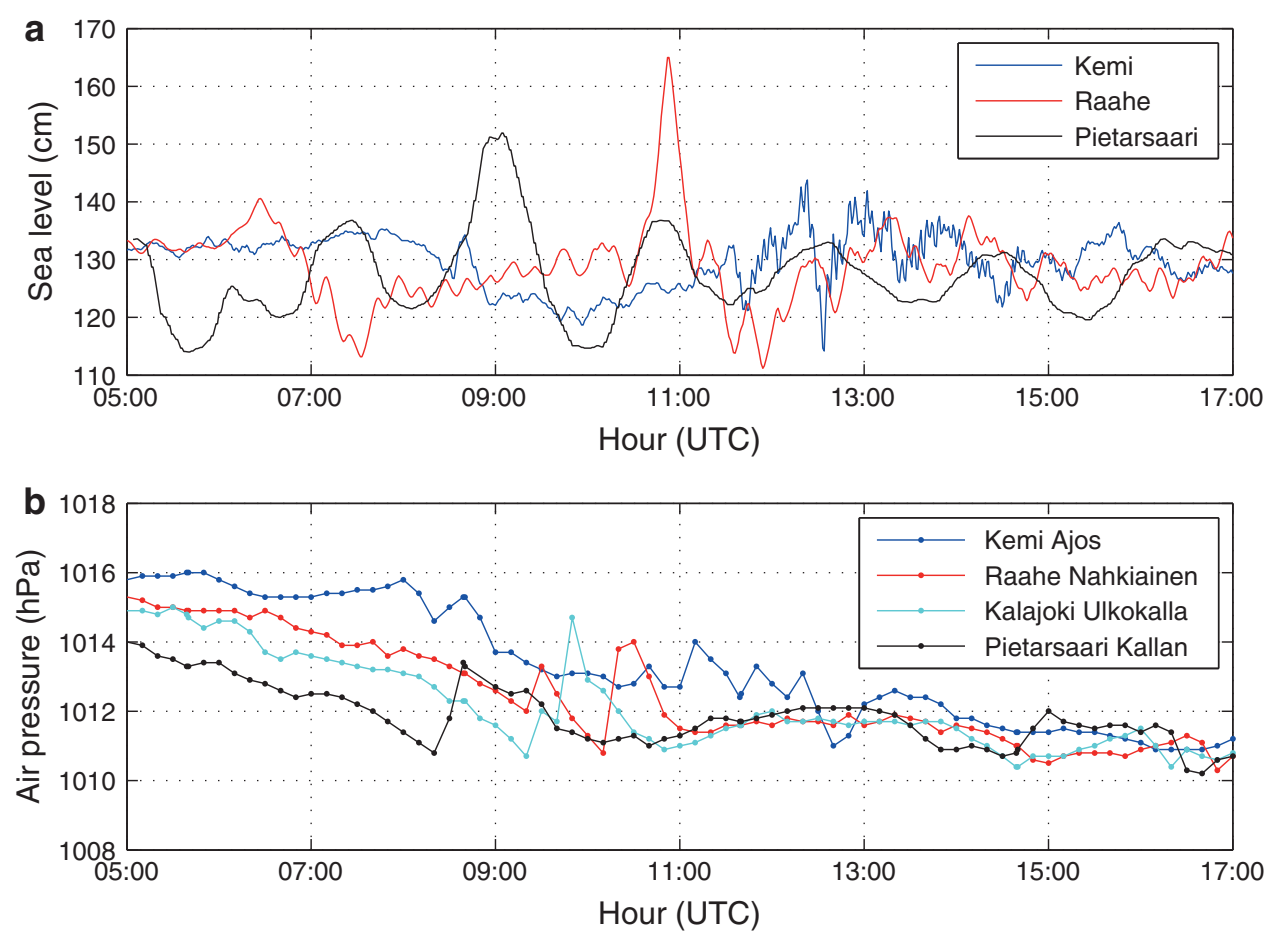

Fig. 9 a One-minute sea-level observations at the Gulf of Bothnia tide gauges during the meteotsunami event of 8 August 2010. The reference level is the tide gauge zero. b Ten-minute sea-level pressure observations at nearby coastal stations (locations marked in Fig. 10)

the coastal air pressure data, the propagation of the squall line is clearly seen as pressure jumps of 2-4 hPa (Fig. 9b).

The average velocity of the squall line as it propagated along the coast was ca. $65 \mathrm{~km} / \mathrm{h}$ $(18 \mathrm{~m} / \mathrm{s})$, corresponding to the long wave speed at a depth of $33 \mathrm{~m}$. This is the prevailing depth of the Gulf of Bothnia at a distance of 20-30 km from the coastline (Figs. 1, 10). The matching of velocities is manifested by the closely matching arrival times of the squall line and sea-level oscillations in Raahe. Using a value of $180 \mathrm{~km}$ for $x_{f}$ and $11 \mathrm{~km}$ for $L$ in Eq. 1, we obtain an amplification factor of 8.2 for the Proudman resonance, thus amplifying the initial $2-4 \mathrm{~cm}$ wave to $16-33 \mathrm{~cm}$. The result 8.2 may be unusually high, because an upper limit of 5.0 has been proposed for the amplification factor due to Proudman resonance alone (Vilibić 2008). However, both tide gauge and eyewitness observations (made about $7 \mathrm{~km}$ apart) have a similar magnitude, indicating that local amplification effects were not dominating in this case and supporting the high amplification factor. Shoaling further amplifies the wave twofold (Eq. 2) to 32-66 cm, in agreement with the observations.

\subsection{The meteotsunami of 4 June 2011}

The only eyewitness report from 4 June 2011 comes from Muusluoto, in the Archipelago Sea, where sea-level oscillations were observed in the evening after 17:00 UTC (Table 1). Three larger waves with a height of $45 \mathrm{~cm}$ and periods of a few minutes were followed by 


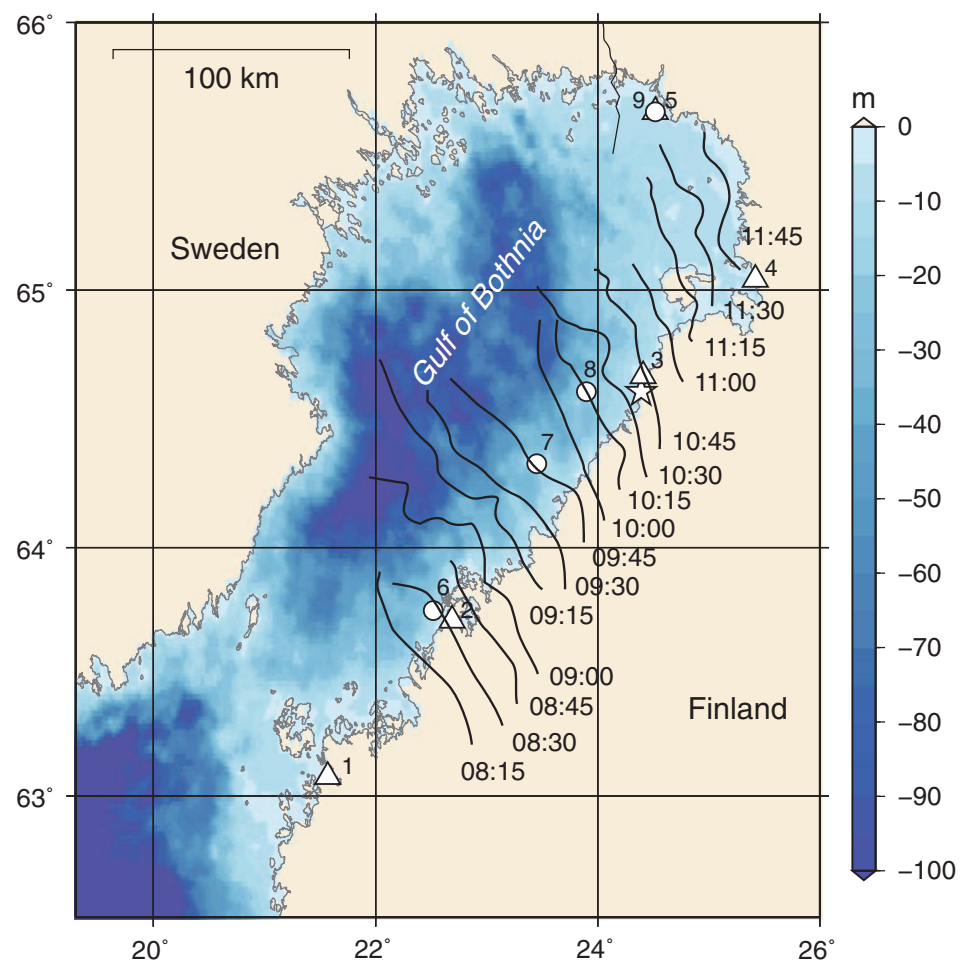

Fig. 10 Squall line propagation over northern Gulf of Bothnia on 8 August 2010. Black lines mark the position of the leading line of the squall line (times UTC). Bathymetry of the gulf is shown in colours with depth in $m$. The star denotes the eyewitness observation site (Siniluoto). Other symbols denote the locations of observation stations: triangles are tide gauges (1 Vaasa, 2 Pietarsaari, 3 Raahe, 4 Oulu, 5 Kemi) and circles meteorological stations (6 Pietarsaari Kallan, 7 Kalajoki Ulkokalla, 8 Raahe Nahkiainen, 9 Kemi Ajos)
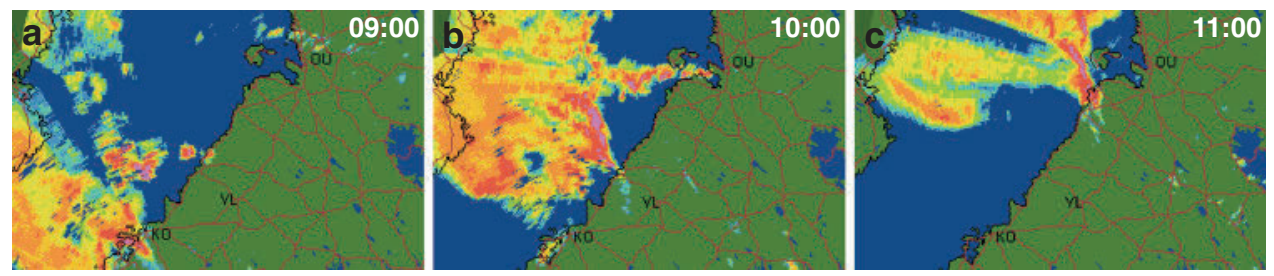

Fig. 11 CAPPI composite reflectivity images of squall line movement over the Gulf of Bothnia on 8 August 2010 at a 09:00, b 10:00 and c 11:00 UTC

weakening oscillations. Altogether, the exceptional sea-level oscillations lasted for more than $1 \mathrm{~h}$.

In sea-level measurements (Fig. 12a), there is no clear indication of rapid peaks at other tide gauges than Degerby, located in Åland, ca. $80 \mathrm{~km}$ southwest from Muusluoto. A small but pronounced peak $10 \mathrm{~cm}$ high was observed at 17:30 UTC, followed by oscillations of a few $\mathrm{cm}$ and a period of ca. $20 \mathrm{~min}$.

This case seems to be caused by a southeastwards moving cold front over the Gulf of Bothnia (Figs. 13, 14). At the time of the eyewitness observation, the front was 

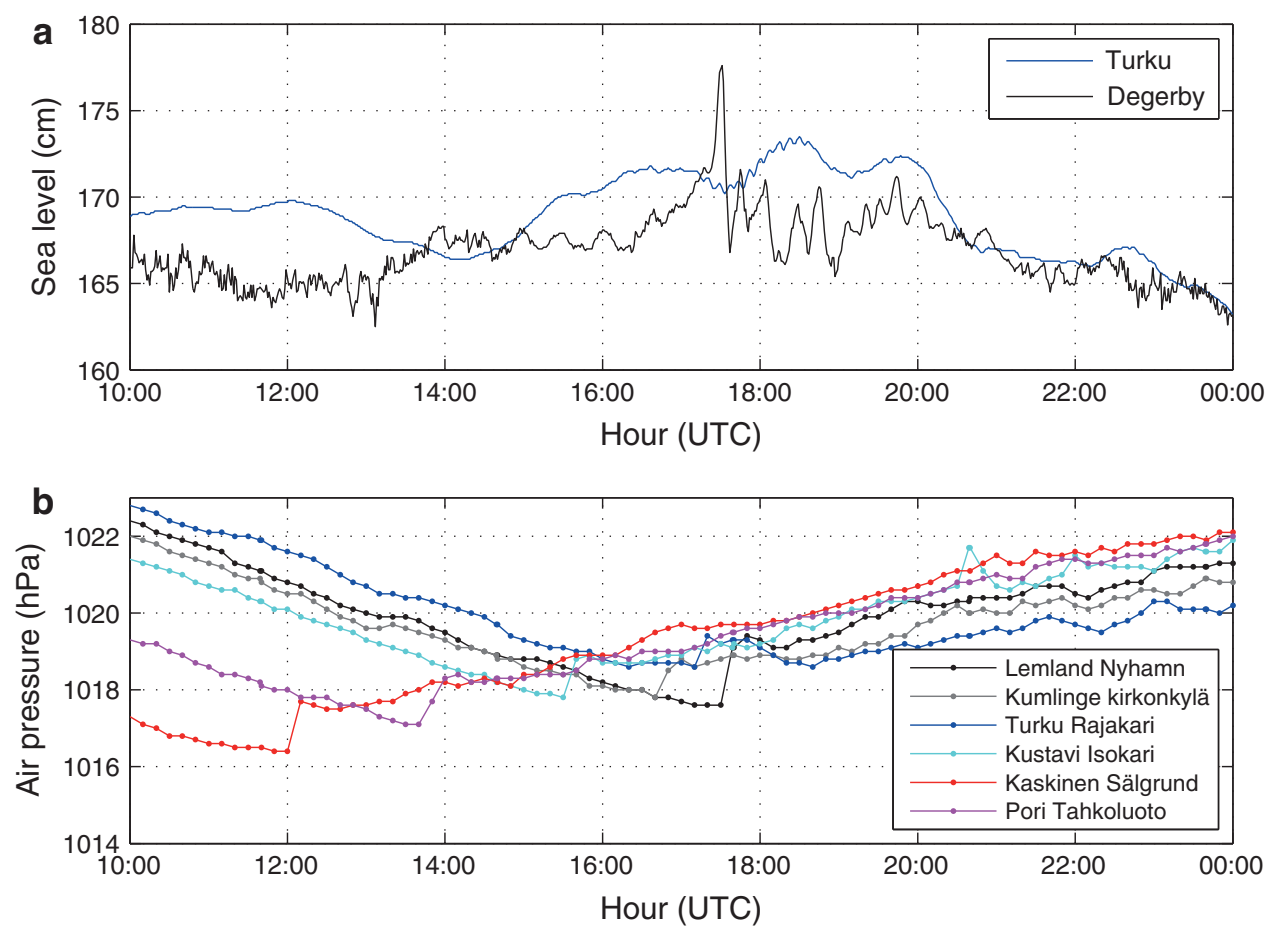

Fig. 12 a One-minute sea-level observations at the tide gauges of Turku and Degerby during the meteotsunami event of 4 June 2011. The reference level is the tide gauge zero. b Ten-minute sea-level pressure observations at nearby coastal stations (locations marked in Fig. 13)

approaching the area from the northwest. Coastal surface air pressure observations on 4 June show a steadily declining pressure during the night and morning, a sudden pressure jump of 1-2 hPa, and a steadily rising pressure after that (Fig. 12b). This southwards propagating pressure jump is clearly related to the cold front movement and sea-level oscillations. In Turku, $30 \mathrm{~km}$ east from Muusluoto, the pressure jump was observed shortly after 17:00 UTC, matching the time of the eyewitness observation. The jump arrived in Lemland at 17:30 UTC, at the same time as the sea-level peak was observed at the nearby Degerby tide gauge.

The speed of the pressure jump as it propagated southwards along the coast was approximately $50-60 \mathrm{~km} / \mathrm{h}(14-17 \mathrm{~m} / \mathrm{s})$, which corresponds to the long wave speed in 20-30 m deep waters. This matches roughly the prevailing long wave speed in the northern Archipelago Sea and coastal Gulf of Bothnia (Fig. 1). Local topographic amplification in the complex archipelago is probably the main cause of the reported oscillations, however, as no sea-level oscillations were recorded by the nearest tide gauge (Turku) and only a small peak was observed at the Degerby tide gauge.

\section{Discussion and conclusions}

The observational data analysed in this study strongly indicate that the exceptional sealevel oscillations observed on the Finnish coast in 2010 and 2011 were of meteorological origin. All of them occurred during the passage of air pressure disturbances moving at a 


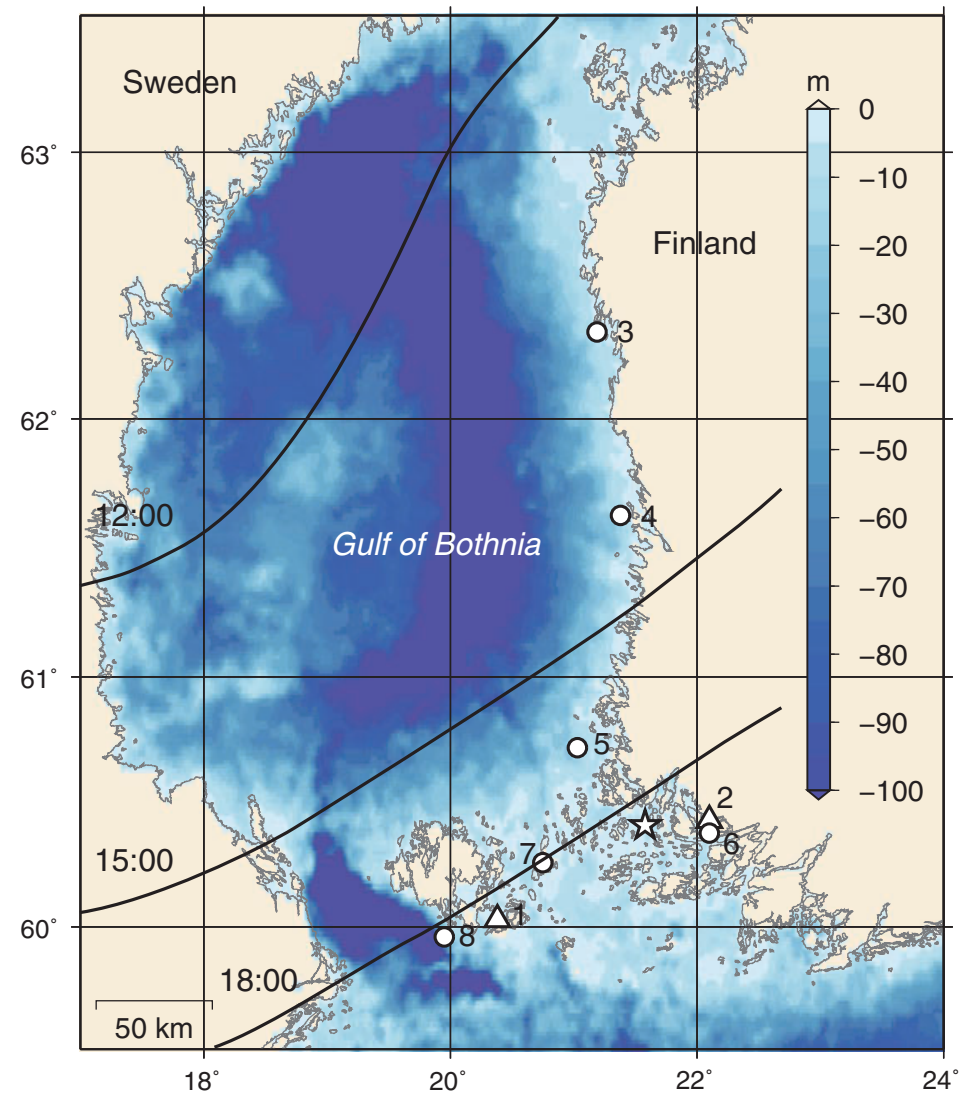

Fig. 13 Cold front propagation over the Gulf of Bothnia and the Archipelago Sea on 4 June 2011. Black lines mark the position of the front (times UTC). Bathymetry of the gulf is shown in colours with depth in $m$. Star denotes the eyewitness observation site (Muusluoto). Other symbols denote the locations of observation stations: triangles are tide gauges (1 Degerby, 2 Turku) and circles meteorological stations (3 Kaskinen Sälgrund, 4 Pori Tahkoluoto, 5 Kustavi Isokari, 6 Turku Rajakari, 7 Kumlinge kirkonkylä, 8 Lemland Nyhamn)
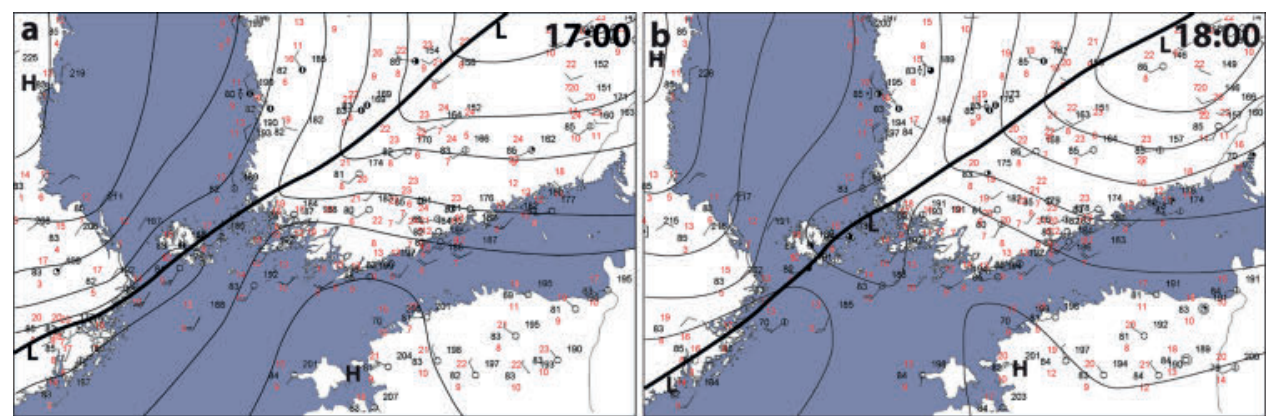

Fig. 14 Surface front and surface pressure perturbation movement over the Archipelago Sea on 4 June 2011 at a 17:00 and b 18:00 UTC. Temperatures, dewpoints, winds, surface pressure, and weather are plotted at station locations. Surface analysis_-isobars and surface lows $(\mathrm{L})$ and highs $(\mathrm{H})$ - is done manually 
speed close to the long wave speed in the sea below, thus enabling efficient energy transfer from the atmosphere to the sea. In the coastal air pressure observations, sea-level oscillations coincided with sudden pressure jumps of a few hectopascals. Thus, the events have the essential characteristics of meteotsunamis, i.e. meteorologically induced tsunami waves.

The air pressure disturbances were caused by different types of weather phenomena and occurred on different scales. On 8 August 2010, two different cases were observed, both caused by a passing squall line. The case on 29 July 2010 was caused by a passing gust front, and the case on 4 June 2011 by a synoptic-scale cold front. Nevertheless, they had similar characteristics: the pressure decreases before the front or squall line and increases immediately after its passage. They also all included high winds perpendicular to the front on its leading line.

Both the cases observed in the Gulf of Finland were caused by air pressure disturbances propagating northwards across the gulf from Estonia, i.e. perpendicular to the coastline. The relatively small width of the gulf $(80 \mathrm{~km})$ and the concave bottom topography limit the distance over which Proudman resonance can act (Fig. 1). The calculated meteotsunami heights were much less than observed, if only the Proudman resonance and shoaling effects were taken into account. In contrast, the case observed in the Gulf of Bothnia was caused by a disturbance moving parallel to the coast, allowing a longer fetch, and a more satisfactory agreement with the calculated and observed wave height was found.

The sea-level oscillations reported by eyewitnesses were anomalous in speed and height compared with typical conditions on the Finnish coast. Tide-gauge measurements show rapid sea-level oscillations at corresponding times, but anomalously high oscillations (close to $1 \mathrm{~m}$ ) are not recorded by tide gauges. This points to the dominating role of local topographically controlled resonance effects. Typically, the eyewitness observations were made at small bays or shallow and narrow straits in the complex Finnish archipelago (Fig. 2d is a good example). Simple analytical solutions, which can be used to estimate the eigenfrequencies of relatively regularly shaped bays or inlets (e.g. Rabinovich 2009), are not applicable. Numerical modelling would be needed to determine the resonant properties of the coast at the observation sites, and to resolve the exact amplification mechanisms behind the observed oscillations. Modelling could also be used to locate possible "meteotsunami hotspots", where strong topographic amplification can occur.

In addition to numerical modelling, an in-depth analysis of the formation of the waves would require high-resolution air pressure and water-level observations of the order of $1 \mathrm{~min}$ (Vilibic and Šepic 2009). The 10 min time resolution of the air pressure data is insufficient to resolve the amplitude of the pressure anomaly (that is, the initial height of the wave) as well as the length scale $L$ in Eq. 1, thus making it difficult to estimate the resonant amplification of the meteotsunami waves.

The fact that we got many independent reports from the general public after decades of no reports requires an explanation. Possibly the reporting threshold has been lowered, e.g. because of increased public awareness due to the widespread attention to the 2004 Indian Ocean tsunami or because of improved connections (internet, mobile phones). Otherwise, we must assume that for some meteorological reason, meteotsunamis have become more frequent and/or their magnitude has increased on the Finnish coast. A long time series of meteotsunami occurrence is needed to find out the answer, but until recently, the digital sea-level data have an insufficient temporal resolution to study rapid sea-level variations. Constructing such a time series is possible by using original tide-gauge chart records, which have the sea level plotted as a continuous curve (manuscript in preparation). 
The events we report are a reason for concern on several accounts: (1) although relatively modest in size, the magnitude of the events is clearly sufficient to cause at least minor damage, (2) it seems that under suitable meteorological circumstances, several meteotsunamis can occur within a short time period, leading to a higher impact than a single event, and (3) based on anecdotal and historical evidence, it is possible that the phenomenon is much more common in the Baltic Sea than has been considered previously.

In some areas in the Mediterranean, meteotsunamis (known locally as rissaga in the Balearic Islands) are a relatively regular phenomenon, and methods have been developed to detect atmospheric disturbances and estimate their speed and direction (e.g. Šepić et al. 2009) with the aim of building an efficient operational warning system. After the meteotsunami observations reported in this paper, warnings of rapid sea-level oscillations have been issued by the FMI when conditions have seemed favourable for the formation of meteotsunamis. With the existing meteorological and oceanographic observation network, the prediction of meteotsunamis on the Finnish coast is possible about $1 \mathrm{~h}$ before the event.

As a first step to aid in the operational work, we have plotted in Fig. 1 the long wave phase speed in the Baltic Sea. Air pressure perturbations such as squall lines moving over the sea at corresponding velocities can, in theory, generate meteotsunamis. The map is intended to serve the on-duty meteorologists, helping them to estimate the risk of meteotsunami formation based on forecast speeds and directions of weather fronts. By using the forecasts and the map together, potential risk times and areas can be identified and warnings can be issued. However, the cause-effect relationship between atmospheric disturbances and meteotsunami-type sea-level oscillations in the Baltic Sea should be more thoroughly established from observations and process models before an operational prediction system can be implemented.

Acknowledgments We thank Pentti Pirinen for providing the air pressure data and Hilppa Gregow for encouragement as well as comments on early versions of the manuscript. We would also like to thank Philip Woodworth, Alexander Rabinovich and an anonymous reviewer for thoughtful comments on the paper. This work has been supported financially by the Finnish Ministry of Employment and the Economy, as a part of the Finnish Research Programme on Nuclear Power Plant Safety 2011-2014 (SAFIR2014).

\section{References}

Credner R (1889) Über den “Seebär” der westlichen Ostsee vom 16/17. Mai 1888. In: III Jahresbericht der geographischen Gesellschaft zu Greifswald 1886-1889, pp 57-96

Defant A (1961) Physical oceanography, vol 2. Pergamon Press, Oxford

Doss B (1907) Über ostbaltische Seebären. Gerlands Beiträge zur Geophysik 8:367-399

Fritsch JM, Forbes GS (2001) Severe convective storms: mesoscale convective systems. Am Meteorol Soc Monogr 28:323-357

Hibiya T, Kajiura K (1982) Origin of the abiki phenomenon (a kind of seiche) in Nagasaki Bay. J Oceanogr Soc Jpn 38:172-182

Institute of Seismology (2013) Seismic events in Northern Europe. Final monthly bulletins (June 2011, August 2010, July 2010). Institute of Seismology of the University of Helsinki. http://www.seismo. helsinki.fi/bulletin/list/pdfbul.html. Accessed 29 Nov 2013

Johansson MM, Pellikka H, Kahma KK, Ruosteenoja K (2014) Global sea level rise scenarios adapted to the Finnish coast. J Mar Syst 129:35-46

Leppäranta M, Myrberg K (2009) Physical oceanography of the Baltic Sea. Springer, Berlin

Lisitzin E (1959) Uninodal seiches in the oscillation system Baltic proper-Gulf of Finland. Tellus 11:459-466

Monserrat S, Vilibić I, Rabinovich AB (2006) Meteotsunamis: atmospherically induced destructive ocean waves in the tsunami frequency band. Nat Hazards Earth Syst Sci 6:1035-1051 
Morrison H, Thompson G (2008) Impact of cloud microphysics on the development of trailing stratiform precipitation in a simulated squall line: comparison of one- and two-moment schemes. Mon Weather Rev 137:991-1007

Piotrowski A, Szczuciński W, Sydor P, Krzymińska J, Seidler J (2013) Hypothetical tsunami deposits in the Rogowo area, Baltic Sea coast, North Poland. In: Grützner C, Rudersdorf A, Pérez-López R, Reicherter $\mathrm{K}$ (eds) Seismic hazard, critical facilities and slow active faults. Proceedings of the 4th international INQUA meeting on Paleoseismology, Active Tectonics and Archeoseismology (PATA Days), 9-15 Oct 2013, Aachen, Germany

Proudman J (1929) The effects on the sea of changes in atmospheric pressure. Geophys Suppl Mon Not R Astron Soc 2:197-209

Rabinovich AB (2009) Seiches and harbor oscillations. In: Kim YC (ed) Handbook of coastal and ocean engineering. World Scientific Publishing, Singapore, pp 193-236

Renqvist H (1926a) Ein Seebär in Finnland. Zur Frage Nach der Entstehung der Seebären. Geogr Ann $8: 230-236$

Renqvist H (1926b) Ett sjösprång. Föredrag vid Finska Vetenskaps-Societetens sammanträde den 22 februari 1926. Finska Vetenskaps-Societeten Minnesteckningar och Föredrag IV:5

Seifert T, Tauber F, Kayser B (2001) A high resolution spherical grid topography of the Baltic Sea, 2nd edn. Baltic Sea Science Congress, 25-29 Nov 2001, Stockholm, Sweden. www.io-warnemuende.de/ iowtopo

Šepić J, Denis L, Vilibić I (2009) Real-time procedure for detection of a meteotsunami within an early tsunami warning system. Phys Chem Earth 34:1023-1031

Törmä A, Rauhala J, Viksna A (2013) A derecho in northeastern Europe on 8 August 2010. 7th European Conference on Severe Storms, 3-7 June 2013, Helsinki, Finland

Vilibić I (2008) Numerical simulations of the Proudman resonance. Cont Shelf Res 28:574-581

Vilibić I, Šepić J (2009) Destructive meteotsunamis along the eastern Adriatic coast: overview. Phys Chem Earth 34:904-917 



\section{III}

(C)2018 Elsevier Ltd.

Reprinted, with kind permission, from

Continental Shelf Research, 157, 32-42

doi:10.1016/j.csr.2018.02.006 



\title{
Future probabilities of coastal floods in Finland
}

\author{
Havu Pellikka, Ulpu Leijala*, Milla M. Johansson, Katri Leinonen, Kimmo K. Kahma \\ Finnish Meteorological Institute, P.O. Box 503, FI-00101 Helsinki, Finland
}

\section{A R T I C L E I N F O}

\section{Keywords:}

Coastal flooding

Flooding risks

Sea level rise

Sea level variability

Baltic Sea

EU Floods Directive

\begin{abstract}
A B S T R A C T
Coastal planning requires detailed knowledge of future flooding risks, and effective planning must consider both short-term sea level variations and the long-term trend. We calculate distributions that combine short- and longterm effects to provide estimates of flood probabilities in 2050 and 2100 on the Finnish coast in the Baltic Sea. Our distributions of short-term sea level variations are based on 46 years (1971-2016) of observations from the 13 Finnish tide gauges. The long-term scenarios of mean sea level combine postglacial land uplift, regionally adjusted scenarios of global sea level rise, and the effect of changes in the wind climate. The results predict that flooding risks will clearly increase by 2100 in the Gulf of Finland and the Bothnian Sea, while only a small increase or no change compared to present-day conditions is expected in the Bothnian Bay, where the land uplift is stronger.
\end{abstract}

\section{Introduction}

Estimating future flooding risks is vital for coastal planning and construction. Accurate flood probability estimates are needed to ensure safe and cost-effective building and to prevent flood damage to infrastructure. Most urban infrastructure has a lifetime of at least 100-200 years, and within this timespan there will be significant long-term sea level changes caused by climate change and other factors. Global mean sea level rose by $10-20 \mathrm{~cm}$ over the 20th century (recent estimates of the rate range from ca. $1.3 \mathrm{~mm} \mathrm{a}^{-1}$ in Hay et al., 2015 and Dangendorf et al., 2017 to $1.9 \pm 0.3 \mathrm{~mm} \mathrm{a}^{-1}$ in Jevrejeva et al., 2014b) and is expected to rise significantly more during the 21 st century.

In Finland, historically the rate of postglacial land uplift has exceeded that of sea level rise, causing a fall in sea level relative to land (e.g. Lisitzin, 1964, Vermeer et al., 1988, Johansson et al., 2014). However, the situation is changing because of higher rates of sea level rise, and the trend of declining relative sea level is currently reversing on the southern coast of Finland. According to the highest sea level scenarios, the rising mean sea level will outstrip the land uplift everywhere on the Finnish coast by 2100 (Johansson et al., 2014). An overview of recent observed changes and scenarios on Baltic Sea level was presented in the Second Assessment of Climate Change for the Baltic Sea Basin (BACC, Hünicke et al., 2015, Grinsted, 2015).

In addition to long-term changes in mean sea level, short-term sea level variations and possible changes in sea level extremes must be considered in coastal management. High sea level can cause severe flooding in the coastal cities of Finland: for example, the storm surge of
9 January 2005 resulted in new sea level records in the Gulf of Finland and caused damage to the value of 12 million euros in Helsinki and elsewhere on the Finnish coast (Anon, 2014). The damage would have been considerably larger without an accurate flood warning $30 \mathrm{~h}$ prior to the event. The short-term variability in sea level has increased in Finland: Johansson et al. (2001) found significant increasing trends in the annual maxima relative to the annual mean sea level during the 20th century.

Sea level in the semi-enclosed Baltic Sea (Fig. 1) is determined by several processes acting on different time scales:

1. The isostatic recovery of the Earth's crust from the pressure of the last glacial era, manifested on the Finnish coast as postglacial land uplift (e.g. Lisitzin, 1964, Ekman, 1996, Lidberg et al., 2007). Important on time scales ranging from decades to millennia.

2. Long-term variations in the level of the northeastern Atlantic Ocean, which affect the Baltic Sea through its ocean outlet, the Danish Straits. From decades to millennia.

3. Variations in the water volume of the Baltic Sea, mainly controlled by wind and air pressure conditions, which regulate the water exchange through the Danish Straits (e.g. Andersson, 2002, Lisitzin, 1962, Vermeer et al., 1988, Samuelsson and Stigebrandt, 1996). From weeks to years.

4. Regional and local short-term variations driven by meteorological forcing. Weather affects sea level directly through wind and air pressure variations and indirectly through secondary phenomena such as internal oscillations (seiches) in the sub-basins of the Baltic

\footnotetext{
* Corresponding author.

E-mail address: ulpu.leijala@fmi.fi (U. Leijala).
} 


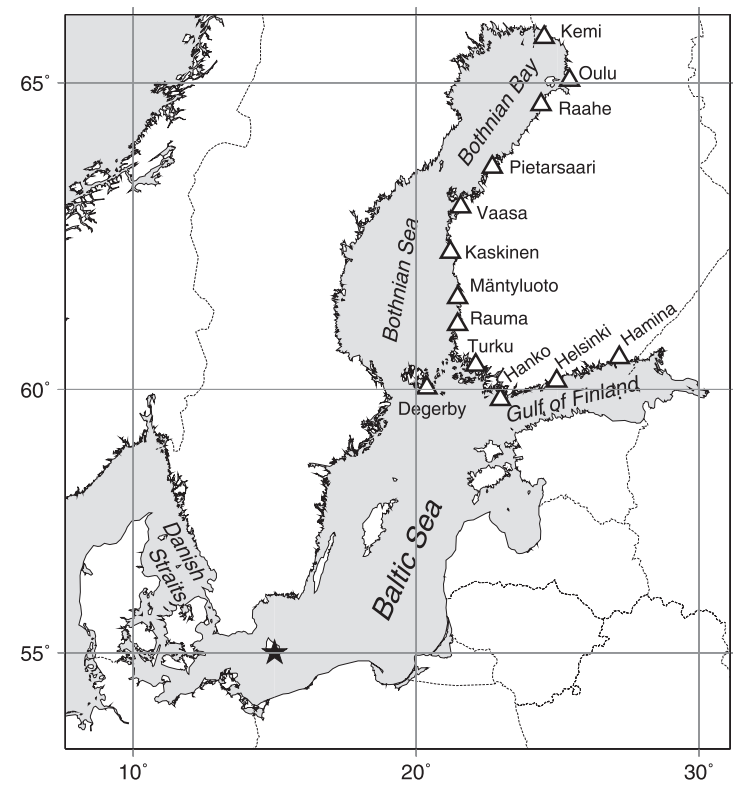

Fig. 1. Map of the Baltic Sea. Locations of the Finnish tide gauges are marked with triangles. The star denotes the point $\left(55^{\circ} \mathrm{N}, 15^{\circ} \mathrm{E}\right)$ used for calculating the annual meteorological sea level component (Section 2.3.2).

Sea (e.g. Lisitzin, 1974, Neumann, 1941, Wübber and Krauss, 1979). From seconds to days.

5. Tides have a minor but observable effect on the Finnish coast (Witting, 1911; Medvedev et al., 2013). From hours to days.

Significant floods occur when multiple factors contributing to high sea level coincide. For example, the coastal flood of 9 January 2005 was caused by the powerful storm Gudrun, which occurred when the mean sea level in the Baltic Sea was already ca. $60 \mathrm{~cm}$ above average due to preceding weather conditions. In addition, a seiche oscillation was ongoing between the Gulf of Finland and the main basin of the Baltic Sea, contributing to the record-breaking sea level peaks in the Gulf of Finland. Tides reduced the maximum by $10 \mathrm{~cm}$ of what it would have been if the peak times would have been coincident.

In this paper, we describe the method used to estimate future probabilities of coastal floods in Finland. We construct probability distributions for short-term sea level variations and long-term mean sea level change, which we then combine to yield estimates of the probability of coastal floods up to 2100 . A probabilistic framework allows the use of our results for different planning purposes depending on the acceptable risk level of the infrastructure in question. The research of this paper is part of the implementation of the EU Floods Directive (2007/60/EC) in Finland, and the method presented here has been applied to give updated recommendations for minimum building elevations on the Finnish coast (Kahma et al., 2014).

Several previous studies have laid the foundation for our work. Our method to determine the distribution of long-term sea level rise and to combine it with the short-term variations originates from an unpublished sea level risk analysis for a nuclear power plant (1990). The method was further developed to produce national recommendations for the lowest building elevations in Finland (Kahma et al., 1998) and subsequently elaborated in several studies concerning nuclear power plant safety. Johansson et al. (2004, 2014) calculated scenarios for mean sea level rise on the Finnish coast in the 21st century. The results presented here update previous assessments with the most recent observations and knowledge, e.g. the Fifth Assessment Report of the
Intergovernmental Panel on Climate Change (IPCC AR5) and several other recent publications.

\section{Data and methods}

\subsection{Finnish tide gauge observations}

Sea level data used in this study comes from 13 tide gauges on the Finnish coast (Fig. 1). Measurements with automatic and continuous gauges started in the 1920s at most stations: longer time series exist from Hanko (1887) and Helsinki (1904), and a somewhat shorter one from Rauma (1933). Up to the 1980s, the tide gauges were equipped with mechanical recording devices whose charts were manually digitized to obtain a time series of sea level observations. In the 1980s, the mechanical instruments were replaced by automated data recording units. The quality-controlled digital sea level database of the Finnish Meteorological Institute contains sea level values at 4-h intervals up to 1970, and values at 1-h intervals after that. Since 1980 the qualitycontrolled monthly and annual maxima and minima are based on measurements with a time resolution of at least 15 min depending on the recording unit.

Gaps in the time series were filled by spatial linear interpolation: missing values were calculated using the measurements at neighbouring stations. Our analysis has shown that linear interpolation is a reliable method for filling most of the gaps (typical root-mean-square error is ca. $2 \mathrm{~cm}$ ), because the tide gauge network is dense enough to make the time series of adjacent stations highly correlated. For Kemi and Hamina, the northernmost and the easternmost stations on the Finnish coastline, missing values were linearly extrapolated using data from the nearest two stations. Other quality corrections have also been applied to the data, see Johansson et al. (2001). In the 4-h data used for analysing long-term sea level variations, the proportion of interpolated or corrected data varies between 1\% (Rauma 1933-2010) and 15\% (Hanko 1888-2010), and the potential error in annual means caused by interpolation proved to be small compared to the natural year-to-year variation in mean sea level (Johansson et al., 2014).

Sea level values in this paper are presented in the Finnish height system N2000, based on the third precise levelling of Finland (1978-2006). The datum is equal to the Normaal Amsterdams Peil (NAP) used in the common European Vertical Reference Frame 2000 (EVRF2000; Saaranen et al., 2009).

\subsection{Separating long-term and short-term sea level variations}

The observed sea level change $h$ at a location $i$ on the Finnish coast can be expressed as the sum of the following components:

$h(t, i)=h_{l}(t, i)-u(i) t+w(t, i)+d(t, i)+\varepsilon(t, i)$

where $t$ is the time since the time of reference, $h_{l}$ is the regional sea level rise, $u$ is the postglacial land uplift proceeding at a constant local rate at the time scales considered, $w$ represents meteorologically induced sea level variations, $d$ tides and $\varepsilon$ residual variations. Residual variations include e.g. local halosteric and thermosteric changes and are small compared to other components.

The meteorologically induced sea level variations $w$ cover a wide range of time scales from seconds to decadal variations. We divide this component in two parts, one representing variations in decadal time scales $\left(w_{m}\right)$ and the other shorter-term variations $\left(w_{s}\right)$ :

$h(t, i)=h_{l}(t, i)-u(i) t+w_{m}(t, i)+w_{s}(t, i)+d(t, i)+\varepsilon(t, i)$

The sum of the three long-term components represents the change in mean sea level and is denoted by $h_{m}$ :

$h_{m}(t, i)=h_{l}(t, i)-u(i) t+w_{m}(t, i)$

When making projections of the flooding risks, we need to assess the future evolution of each of these three components that contribute to 
the long-term mean sea level on the Finnish coast (Section 2.3). The remaining short-term variations are estimated by removing the three long-term components from the observed sea levels (Section 2.4):

$h_{s}(t, i)=h(t, i)-h_{m}(t, i)$

To the first approximation, we estimate that the distribution of short-term variations $h_{s}$ remains unchanged in the future. We can then combine the future scenarios of $h_{m}$ and the observation-based distributions of $h_{s}$ to yield future estimates of $h$.

\subsection{Long-term mean sea level change}

In this section, we determine probability distributions for mean sea level change on the Finnish coast up to 2100. For this purpose, we need to estimate the three components contributing to the long-term mean sea level change $h_{m}$ on the Finnish coast (Eq. (3)):

1. Regional sea level rise $h_{l}$. Global mean sea level (GMSL) is rising at an accelerating rate (Jevrejeva et al., 2014b; Dangendorf et al., 2017) because of the thermal expansion of warming sea water and the melting of land-based glacier ice. There is considerable spatial variation in the rate of sea level rise: the melting of glaciers and ice sheets affects sea level unevenly, and the uneven warming of the oceans as well as changes in the ocean circulation and in wind and air pressure patterns cause regional deviations from the global mean (Mitrovica et al., 2001; Church et al., 2013).

2. Postglacial land uplift $u$. In Finland, the bedrock is still slowly recovering from the pressure of the ice sheet during the last glacial era. This postglacial land uplift significantly compensates for sea level rise. The land uplift rate is highest in the Bothnian Bay, up to 9-10 $\mathrm{mm} \mathrm{a}^{-1}$ (Hill et al., 2010; Johansson et al., 2014).

3. Long-term meteorological changes $w_{m}$. Wind conditions in the Danish Straits correlate well with annual and monthly sea level variations on the Finnish coast (Johansson et al., 2014; Johansson and Kahma, 2016), because wind and air pressure variations regulate the volume and distribution of water in the semi-enclosed Baltic Sea. As a simple illustration, westerly winds push water from the North Sea through the Straits and pile up water against the Finnish coast, while easterly winds drive water in the opposite direction and cause lower sea levels around Finland. Therefore, longterm changes in the wind climate affect mean sea level on the Finnish coast.

\subsubsection{Constructing scenarios for regional sea level rise}

We construct probability distributions of future sea level rise by combining several predictions in recent scientific literature. Our approach stems from the lack of comprehensive sea level scenarios in the IPCC assessments. There are considerable uncertainties in GMSL predictions, the most significant being dynamic changes in the Greenland and Antarctic ice sheets. In particular, the ice streams of the West Antarctic Ice Sheet, which rests on a marine base below sea level, are considered unstable and prone to unstoppable retreat or "collapse" (Mercer, 1978; Schoof, 2007; Joughin et al., 2014; Rignot et al., 2014). Current models are not able to provide robust estimates of future changes in ice sheet dynamics, and the estimates included in the IPCC AR5 scenarios are largely based on extrapolations of recent ice sheet mass loss. The AR5 concludes that while a larger collapse of the marine sectors of the Antarctic ice sheet is not likely, it cannot be excluded and may result in an additional sea level rise in the order of several decimetres during this century (Church et al., 2013).

Because of these uncertainties, we construct our sea level rise distributions using an ensemble of 14 predictions available in recent literature, based on different methods (Table 1, Fig. 3). Process-based studies attempt to model each sea level rise component separately, but need to be supplemented with expert judgement to assess future changes in ice sheet dynamics. In contrast, semi-empirical models are based on an empirical relationship between some climatic variable (e.g. the global mean temperature) and GMSL. We scale all predictions in Table 1 to a common time interval 2000-2100 by making a quadratic fit to sea level rise values given for different years and subtracting the rise by 2000 . If only sea level rise in 2100 is available, we make the fit assuming a start rate of $3.2 \pm 0.4 \mathrm{~mm} / \mathrm{yr}$ (the rate of sea level rise in 1993-2010, Church et al., 2013).

Next, we adjust the scenarios to take into account regional deviations from the global mean. For this purpose, the Finnish coastline is divided in three regions: the Gulf of Finland, the Bothnian Sea, and the Bothnian Bay (Fig. 1). We scale the glacier and ice sheet contributions with regional coefficients to account for the so-called fingerprint effect: when mass is transported from an ice sheet to the ocean, changes in the Earth's gravitational field and crustal loading result in an uneven geographical pattern ("fingerprint") of sea level rise. We derive the fingerprint coefficients from Mitrovica et al. (2001) and Tamisiea et al. (2003), taking the average of the fingerprint range presented in their figures. According to their model results, the Baltic Sea is located on the zero line of the Greenland fingerprint: melting of the Greenland ice sheet will result in sea level fall in the Bothnian Bay, while sea level rise of $0-10 \%$ and $10-20 \%$ of the global mean will take place in the Bothnian Sea and the Gulf of Finland, respectively. Hence, we scale the Greenland contributions with coefficients 0 for the Bothnian Bay, 0.05 for the Bothnian Sea, and 0.15 for the Gulf of Finland. By contrast, the effect of Antarctic melting is slightly above the global average in the Baltic Sea (100-110\%, Tamisiea et al., 2003); the coefficient 1.05 is used for all regions to scale the Antarctic contribution. Coefficients applied to glaciers and ice caps are 0.5 for the Bothnian Bay and 0.65 for the Bothnian Sea and the Gulf of Finland (derived similarly from Mitrovica et al., 2001).

Regional variations in ocean temperature and salinity changes also cause regional deviations from GMSL rise, as do changes in ocean circulation and atmospheric pressure. Current climate models indicate that these changes will result in larger than average sea level rise in the North Sea-Baltic Sea region (Church et al., 2013; Simpson et al., 2014; Slangen et al., 2014). We assess this component using results from an ensemble of 21 CMIP5 (Coupled Model Intercomparison Project Phase 5) atmosphere-ocean general circulation models, used in IPCC AR5 and available through the Integrated Climate Data Center, University of Hamburg, Germany (icdc.cen.uni-hamburg.de). For each Representative Concentration Pathway (RCP) scenario, we calculate the mean of the 10 grid boxes bordering the coastline of Finland for the central, lower (5\%) and upper (95\%) estimates. The resulting regional sea level rise caused by thermal expansion and ocean dynamics is $17 \mathrm{~cm}$ $(9-25 \mathrm{~cm})$ for RCP2.6, $26 \mathrm{~cm}(15-38 \mathrm{~cm})$ for RCP4.5 and RCP6.0, and $43 \mathrm{~cm}(27-60 \mathrm{~cm})$ for RCP 8.5 in 2081-2100 compared to 1986-2005. We use the same results for the whole coastline, as the regional variations are small compared to the uncertainties (within a few centimetres). The mean over the Finnish coast is also very close to the mean over the whole Baltic Sea. Compared to the mean over the North Sea, the central estimates are $3-4 \mathrm{~cm}$ higher on the Finnish coast, but the uncertainty ranges are narrower.

Process-based projections and the semi-empirical study of Mengel et al. (2016) assess the sea level contributions of different components separately. By applying the fingerprint coefficients to the glacier and ice sheet contributions and by replacing the contribution of thermal expansion with the regional estimates presented above, we obtain estimates of regional sea level rise on the Finnish coast. An example of the component-wise regionalization of the global predictions is shown in Table 2 for the RCP4.5 scenario of IPCC AR5.

Other semi-empirical projections provide only total sea level rise values and cannot be adapted similarly. Instead, we use a scaling method by examining the ratio of regional to global sea level rise using the results from the component-wise adaptations. For all three regions, we make a linear fit to the available pairs of global and regional sea level rise (see Fig. 2 for an example) and use these functions to convert 
Table 1

Predictions of GMSL rise which were combined to create scenarios for regional sea level rise on the Finnish coast. Each prediction was given a weight based on expert judgement.

\begin{tabular}{|c|c|c|c|c|c|}
\hline Publication & GMSL rise $(\mathrm{cm})$ & Time period & Probability range & Method & Weight \\
\hline Mengel et al. (2016) & $28-131$ & 2100 relative to $1986-2005$ & $5-95 \%$ & Semi-empirical & 0.5 \\
\hline Kopp et al. (2016) & $24-131$ & $2000-2100$ & $5-95 \%$ & Semi-empirical & 0.5 \\
\hline Kopp et al. (2014) & $29-121$ & $2000-2100$ & $5-95 \%$ & $\begin{array}{l}\text { Process-based models }+ \text { expert } \\
\text { judgement }\end{array}$ & 1 \\
\hline $\begin{array}{l}\text { Jevrejeva et al. (2014a)/Grinsted et al. } \\
\text { (2015) }\end{array}$ & $45-183$ & $2000-2100$ & $5-95 \%$ & $\begin{array}{l}\text { Process-based models }+ \text { expert } \\
\text { judgement }\end{array}$ & 1 \\
\hline IPCC AR5 (Church et al., 2013) & $26-82$ & $\begin{array}{l}2081-2100 \text { relative to } \\
1986-2005\end{array}$ & $\begin{array}{l}5-95 \% \text { (likely range, at least } 66 \% \\
\text { probability) }\end{array}$ & $\begin{array}{l}\text { Process-based models }+ \text { expert } \\
\text { judgement }\end{array}$ & 4 \\
\hline Jevrejeva et al. (2012) & $36-165$ & 2100 relative to $1980-2000$ & $5-95 \%$ & Semi-empirical & 0.5 \\
\hline Katsman et al. (2011) & $52-111$ & $1990-2100$ & 5-95\% (assumed) & $\begin{array}{l}\text { Process-based models }+ \text { expert } \\
\text { judgement }\end{array}$ & 1 \\
\hline Jevrejeva et al. (2010) & $44-178$ & 2100 relative to $1980-2000$ & $5-95 \%$ & Semi-empirical & 0.5 \\
\hline Grinsted et al. (2010) & $72-160^{\mathrm{b}}$ & $\begin{array}{l}2090-2099 \text { relative to } \\
1980-1999\end{array}$ & $5-95 \%$ & Semi-empirical & 0.5 \\
\hline Vermeer and Rahmstorf (2009) & 75-190 & $1990-2100$ & 5-95\% (based on Meehl et al., 2007) & Semi-empirical & 0.5 \\
\hline Pfeffer et al. (2008) & 79-201 & by 2100 & 5-99\% (assumed) & Expert judgement & 1 \\
\hline Katsman et al. (2008) & $34-87^{\mathrm{a}}$ & $1990-2100$ & $10-90 \%$ & $\begin{array}{l}\text { Process-based models }+ \text { expert } \\
\text { judgement }\end{array}$ & 1 \\
\hline Horton et al. (2008) & $47-100$ & 2100 relative to $2001-2005$ & 5-95\% (based on AR4) & Semi-empirical & 0.5 \\
\hline Rahmstorf (2007) & $50-140$ & $1990-2100$ & $\begin{array}{l}2.5-97.5 \% \text { (based on Cubasch et al., } \\
2001 \text { ) }\end{array}$ & Semi-empirical & 0.5 \\
\hline
\end{tabular}

${ }^{a}$ Local gravity corrections and local steric changes are not included, in contrast to the total values presented by Katsman et al. (2008).

b Their experiment 'Moberg', which gives the best fit to global sea level reconstruction.

the global semi-empirical projections to regional values. To better constrain the high end of the scaling functions, we include a worst-case estimate following Jevrejeva et al. (2014a), but replacing their Antarctic contribution $(39 \mathrm{~cm})$ with $114 \mathrm{~cm}$ from DeConto and Pollard (2016), who suggest that Antarctica could contribute more than $1 \mathrm{~m}$ of sea level rise during this century. Our analysis indicates that the total sea level rise on the Finnish coast over the 21st century will be roughly $80 \%$ of the global average (the slope of the linear fit is 0.81 for the Gulf of Finland, 0.78 for the Bothnian Sea, and 0.75 for the Bothnian Bay).

To obtain a probability distribution of sea level rise, we fit a Weibull distribution to each prediction and calculate a weighted sum of the distributions. The weighted sum of the distributions without regionalization is our estimate of the probability distribution of GMSL rise (Fig. 3). When we apply the regionalization methods described above, we get a probability distribution for sea level rise in 2000-2100 for each of the three regions on the Finnish coast. The Weibull distribution was chosen because it allows asymmetrical distributions while having similar properties to the normal (Gaussian) distribution. Uncertainty ranges in sea level predictions are typically asymmetrical: the distributions have a longer tail towards high-end predictions. We determine the distribution parameters based on three constraints: the probability levels of minimum and maximum scenarios (5\% and $95 \%$ in

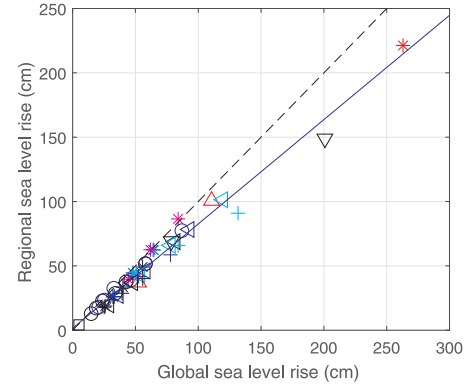

* IPCC AR5: RCP2.6 * IPCC AR5: RCP4.5 * IPCC AR5: RCP6.0 * IPCC AR5: RCP8.5 Katsman et al. (2011) Katsman et al. (2008): moderate Katsman et al. (2008): warm $\nabla$ Pfeffer et al. (2008) Kopp et al. (2014): RCP2. $\checkmark$ Kopp et al. (2014): RCP4.5 Kopp et al. (2014): RCP8.5 Mengel et al. (2016): RCP2. Mengel et al. (2016): RCP4. Mengel et al. (2016): RCP8 .5 * Worst case

Observed 1993-2010

Fig. 2. Regional vs. global sea level rise in the Gulf of Finland, derived from the projections to which the component-wise adaptation was applied. Blue line is the linear fit to all points, dashed line represents the case where global and regional sea level rise are equal.

most cases, Table 1) and the peak of the distribution, which is iteratively fitted close to the best estimate. The best estimates were set at the arithmetic mean of the best estimates given for different emission scenarios, or simply at the mean of the minimum and maximum scenarios,

Table 2

Adapting the RCP4.5 sea level scenario of IPCC AR5 (Church et al., 2013) to three different regions on the Finnish coast. Values are cm in 2081-2100 relative to 1986-2005. Total values for other RCP scenarios are also shown.

\begin{tabular}{|c|c|c|c|c|}
\hline & Global (Church et al., 2013: Table 13.5) & Gulf of Finland & Bothnian Sea & Bothnian Bay \\
\hline Thermal expansion + ocean dynamics & $19(14-23)$ & $26.3(14.5-38.2)$ & $26.3(14.5-38.2)$ & $26.3(14.5-38.2)$ \\
\hline Glaciers $^{\mathrm{a}}$ & $12(6-19)$ & $7.8(3.9-12.4)$ & $7.8(3.9-12.4)$ & $6(3-9.5)$ \\
\hline Greenland SMB ${ }^{\mathrm{b}}$ & $4(1-9)$ & $0.6(0.15-1.35)$ & $0.2(0.05-0.45)$ & 0 \\
\hline Antarctic SMB ${ }^{c}$ & $-2(-5$ to -1$)$ & $-2.1(-5.25$ to -1.05$)$ & $-2.1(-5.25$ to -1.05$)$ & $-2.1(-5.25$ to -1.05$)$ \\
\hline Greenland dynamics $^{\mathrm{b}}$ & $4(1-6)$ & $0.6(0.15-0.9)$ & $0.2(0.05-0.3)$ & 0 \\
\hline Antarctic dynamics ${ }^{c}$ & $7(-1$ to 16$)$ & 7.35 ( -1.05 to 16.8$)$ & $7.35(-1.05$ to 16.8$)$ & $7.35(-1.05$ to 16.8$)$ \\
\hline Land water storage & $4(-1$ to 9$)$ & $4(-1$ to 9$)$ & $4(-1$ to 9$)$ & $4(-1$ to 9$)$ \\
\hline Total (RCP4.5) & $47(32-63)$ & $45(26-62)$ & $44(25-61)$ & $42(23-59)$ \\
\hline Total (RCP2.6) & $40(26-55)$ & $34(19-49)$ & $33(18-48)$ & $31(17-46)$ \\
\hline Total (RCP6.0) & $48(33-63)$ & $45(26-62)$ & $44(26-61)$ & $42(24-58)$ \\
\hline Total (RCP8.5) & $63(45-82)$ & $63(40-86)$ & $61(39-85)$ & $58(36-81)$ \\
\hline
\end{tabular}

${ }^{a}$ Fingerprint coefficients for small glaciers and ice caps: 0.65 (Gulf of Finland), 0.65 (Bothnian Sea), and 0.5 (Bothnian Bay).

${ }^{\mathrm{b}}$ Fingerprint coefficients for Greenland: 0.15 (Gulf of Finland), 0.05 (Bothnian Sea), 0 (Bothnian Bay).

${ }^{\mathrm{c}}$ Fingerprint coefficients for Antarctica: 1.05 for all three regions. 


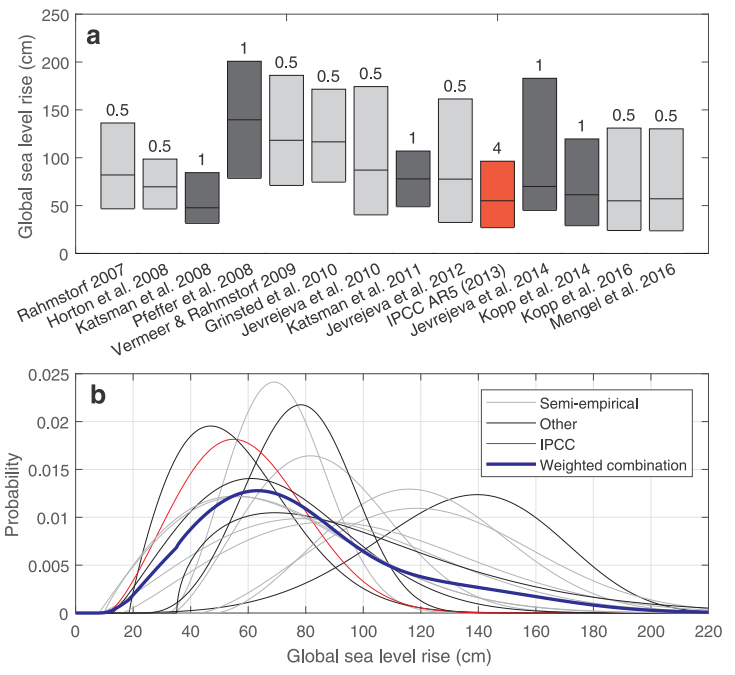

Fig. 3. a) The ensemble of GMSL predictions (Table 1) scaled to a common time span 2000-2100. Colour indicates the method used: semi-empirical (grey) or process-based (black), except IPCC AR5 (red). The numbers above the bars indicate the weight applied to each prediction. b) Weibull distributions fitted to the predictions of GMSL rise and their weighted sum (blue).

if no other information was available. When the uncertainty ranges are symmetrical, the Weibull fit is practically equal to a Gaussian fit.

We note that the uncertainty ranges of IPCC AR5 are 5-95\% ranges of the model results, but they were assessed by IPCC to be of medium confidence (at least $66 \%$ probability) and are thus commonly interpreted as $17-83 \%$ ranges. We include them as $5-95 \%$ ranges, however, for two reasons: 1) our ensemble includes many projections that extend higher than the IPCC ranges; in fact, our method is designed to take into account the possibility that the IPCC ranges can be exceeded, and 2) applying the wider uncertainty limits and our fitting method makes the distribution extend below zero in the low end, which we consider unrealistic.

The weights used to calculate the total distribution are based on expert judgement and aim at a balanced composition of different methods. IPCC AR5 was given the largest weight (4) because it represents the most comprehensive estimate of global sea level rise. Other process-based estimates are included with a weight of 1 . Generally, semi-empirical models result in higher sea level predictions than process-based models, but their reliability is controversial (Church et al., 2013). Because of lower confidence in semi-empirical predictions and their large number in the ensemble, we include these predictions with a lower weight of 0.5 . The effect of weighting the predictions is examined in Section 3.3.

\subsubsection{Estimating land uplift and the long-term meteorological component}

We follow Johansson et al. (2014) in determining the land uplift and the long-term meteorological sea level changes. Land uplift rates $u$ at the tide gauges are calculated as a residual trend that remains when the long-term meteorological changes $w_{m}$ and the regional sea level rise $h_{l}$ are removed from the observed time series of annual mean sea level up to the year 2000. From Eq. (3) we get

$-u(i) t=h_{m}(t, i)-h_{l}(t, i)-w_{m}(t, i)$

where $t$ is time and $h_{m}$ is the mean sea level relative to land observed at a tide gauge $i$. Regional sea level rise is approximated with the global mean rate $g$ of $1.7 \pm 0.2 \mathrm{~mm} \mathrm{a}^{-1}$ (Church et al., 2013) and assumed to have proceeded linearly during the 20th century. Assuming linearity is an approximation, as there has been acceleration in the rate of sea level rise towards the end of the 20th century, but since the exact regional rate and variations therein over time are unknown, we make this assumption for simplicity.

We use the results of Johansson et al. (2014) for the long-term meteorological component $w_{m}$. In short, they calculated linear regression between the detrended annual mean sea level up to 2000 and detrended annual zonal geostrophic wind at $55^{\circ} \mathrm{N}, 15^{\circ} \mathrm{E}$ (Fig. 1), in the southern Baltic Sea near the Danish Straits. This point showed the best correlation between the zonal geostrophic wind $\left(U_{g}\right)$ and the sea level on the Finnish coast. The regression coefficients $p_{i}$ were then used to estimate the annual meteorological sea level components: $w_{a}(t)$ $=p_{i} U_{g}(t)$. The geostrophic winds were calculated from daily mean sea level pressure fields for the years 1899-2010; for more details, see Johansson et al. (2014). According to their analysis, the variations in zonal geostrophic wind explain $84-89 \%$ of variations in annual mean sea level on the Finnish coast.

When we replace the mean sea level $h_{m}$ with observed annual means $h_{a}$ up to 2000 (calculated from 4-h sea level data) and the long-term meteorological component $w_{m}$ with annual values $w_{a}$, from Eq. (5) we get

$$
-u(i) t=h_{a}(t, i)-g t-p_{i} U_{g}(t)
$$

This calculation results in land uplift rates varying from 4 to $5 \mathrm{~mm} \mathrm{a}^{-1}$ in the Gulf of Finland to $9-10 \mathrm{~mm} \mathrm{a}^{-1}$ in the Bay of Bothnia (Table 3). These values are comparable with those obtained from GIA (Glacial Isostatic Adjustment) modelling (e.g. Hill et al., 2010).

To estimate the future sea level contribution of $w_{m}$, the regression coefficients from the 20th century observations were combined with future scenarios of zonal geostrophic wind (20 year means) from an ensemble of nine climate models. Johansson et al. (2014) concluded that increasing zonal winds lead to increasing sea levels on the Finnish coast. On average, the effect was estimated to be $6-7 \mathrm{~cm}$ by $2081-2100$, with values ranging from a $3-4 \mathrm{~cm}$ decrease to a $15-19 \mathrm{~cm}$ increase depending on the station.

Finally, we calculate $h_{m}$ - the sum of the three long-term sea level components (Eq. (3)) - over the 20th century. The annual meteorological sea level component $w_{a}$ varies from year to year, the variations in the annual means being of the order of $20 \mathrm{~cm}$. To smooth out this variation and to get an estimate for the decadal-scale meteorological component $w_{m}$, we calculate 15-year floating averages of $w_{a}$. By combining these 15-year floating average time series with the past GMSL rise $g$ and the linear land uplift $u$, we get an estimate of $h_{m}$ at each

Table 3

Land uplift rates and scenarios for mean sea level change at the Finnish tide gauges over the 21 st century. The average scenario is the weighted average of the probability distribution, high and low scenarios correspond to the $5 \%$ and $95 \%$ cumulative probabilities. "Region" indicates which regional sea level rise estimate was used for each tide gauge: Bay of Bothnia (BB), Bothnian Sea (BS), and Gulf of Finland (GoF). The uncertainties in land uplift rates are $95 \%$ confidence limits (two standard deviations).

\begin{tabular}{|c|c|c|c|c|c|}
\hline \multirow[t]{2}{*}{ Tide gauge } & \multirow[t]{2}{*}{ Region } & \multirow[t]{2}{*}{$\begin{array}{l}\text { Land uplift rate } \\
\left(\mathrm{mm} \mathrm{a}^{-1}\right)\end{array}$} & \multicolumn{3}{|c|}{$\begin{array}{l}\text { Mean sea level change } 2000-2100 \\
(\mathrm{~cm})\end{array}$} \\
\hline & & & Low & Average & High \\
\hline Kemi & BB & $9.66 \pm 0.59$ & -71 & -28 & 24 \\
\hline Oulu & BB & $9.30 \pm 0.58$ & -69 & -25 & 27 \\
\hline Raahe & BB & $9.66 \pm 0.56$ & -71 & -28 & 24 \\
\hline Pietarsaari & BB & $9.74 \pm 0.54$ & -72 & -29 & 23 \\
\hline Vaasa & $\mathrm{BB}$ & $9.85 \pm 0.52$ & -74 & -31 & 21 \\
\hline Kaskinen & BS & $9.36 \pm 0.54$ & -66 & -22 & 33 \\
\hline Mäntyluoto & BS & $8.49 \pm 0.53$ & -58 & -13 & 42 \\
\hline Rauma & BS & $7.67 \pm 0.55$ & -50 & -5 & 50 \\
\hline Turku & BS & $6.33 \pm 0.52$ & -36 & 8 & 63 \\
\hline Degerby & BS & $6.48 \pm 0.51$ & -39 & 6 & 61 \\
\hline Hanko & GoF & $5.00 \pm 0.50$ & -22 & 24 & 80 \\
\hline Helsinki & GoF & $4.37 \pm 0.51$ & -15 & 30 & 87 \\
\hline Hamina & GoF & $4.05 \pm 0.59$ & -13 & 33 & 90 \\
\hline
\end{tabular}




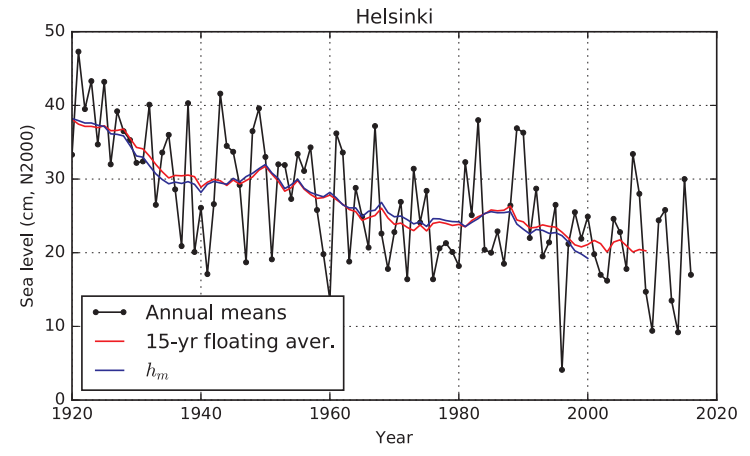

Fig. 4. Observed annual mean sea levels in Helsinki (black), their 15-year floating average (red) and the sum of the three long-term sea level components ( $h_{m}$, blue): land uplift, GMSL rise and the long-term meteorological sea level change.

station (see Fig. 4 for Helsinki). This estimate is used to separate the short-term variations from the long-term mean when forming the probability distribution of short-term sea level variations (Section 2.4).

\subsubsection{Probability distributions of future mean sea level change}

We combine the probability distributions of the three long-term sea level components (regional sea level rise, land uplift, and long-term meteorological changes) to obtain a probability distribution of mean sea level change in 2000-2100 for each tide gauge (Fig. 5). We assume that land uplift will continue at a constant rate and fit normal distributions to the land uplift values and their 95\% confidence limits (Table 3). The distributions of the long-term meteorological component are obtained from Johansson et al. (2014), who estimated future scenarios of the component by assuming that the relation between zonal geostrophic wind and sea level on the Finnish coast will remain the same in the future.

In addition, we calculate a distribution for mean sea level change in 2000-2050 for each tide gauge. We fit a second-order polynomial with respect to time to the sea levels corresponding to each cumulative probability level in 2000 and 2100, assuming a sea level rise rate of $3.2 \pm 0.4 \mathrm{~mm} \mathrm{a}^{-1}$ in 2000 (Church et al., 2013 for 1993-2010), to obtain the sea level representing that probability level in 2050.

\subsection{Short-term sea level variations}

As we are estimating the long-term flooding probabilities, we need to study the distribution of maximum sea level values. Short-term sea level distributions in this paper are based on the last 46 years (1971-2016) of monthly maxima from each tide gauge. To obtain the short-term variations, we subtract the estimated long-term mean sea level $h_{m}$ (Eq. (3), Fig. 4) from the observed monthly maxima. These remaining short-term maxima $h_{s}$ represent sea level variations from which the three long-term components - land uplift, global sea level rise, and long-term meteorological changes (on a 15-year and longer time scale) - have been eliminated. From these short-term variations, we calculate the exceedance frequency distribution of monthly maxima for each tide gauge.

As mentioned previously, there is a site-dependent trend towards increasing annual sea level maxima (relative to the mean) on the Finnish coast. Also the probability distribution of sea level has changed with time: high sea level values have had higher probabilities of occurrence during the recent decades than in the early 20th century (Johansson et al., 2001). The reason for this change is uncertain and we do not know what will happen in the future. To avoid underestimation, we do not use the full time series (ca. 100 years) to derive the shortterm distributions. The period chosen (1971-2016) is sufficiently long for a reasonably stable distribution.

The exceedance frequencies obtained from a 46-year time series only cover return periods of up to 46 years. To estimate the sea levels with lower exceedance frequencies, we extrapolate the distributions with an exponential distribution. Särkkä et al. (2017) applied different extrapolation functions to 30 years of observed daily maxima in Helsinki and compared them with 850 years of simulated sea level data. They concluded that the exponential and Weibull fits had the best
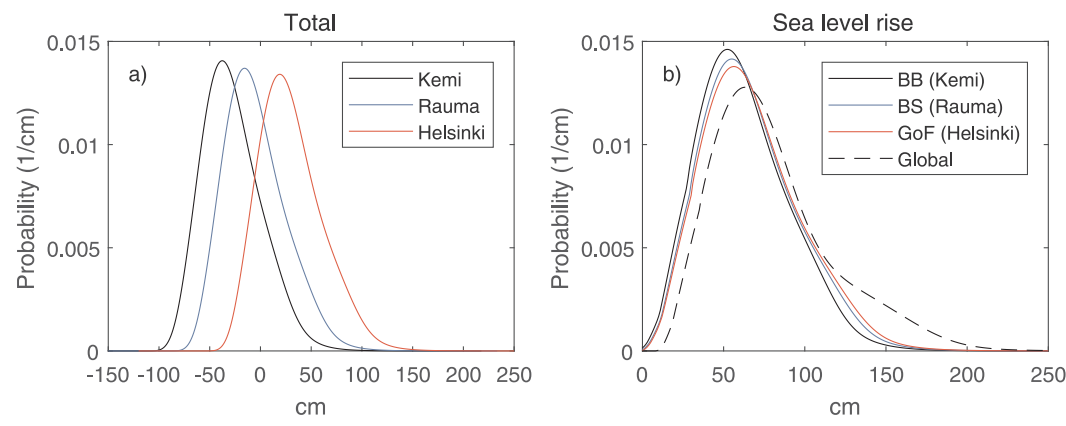

Fig. 5. Probability density functions of a) total mean sea level change $h_{m}$ from 2000 to 2100 and its components (b-d): regional sea level rise (also the distribution for GMSL rise shown), land uplift, and long-term meteorological changes in mean sea level. The distributions are shown for three tide gauges: Kemi in the Bothnian Bay (BB), Rauma in the Bothnian Sea (BS), and Helsinki in the Gulf of Finland (GoF)
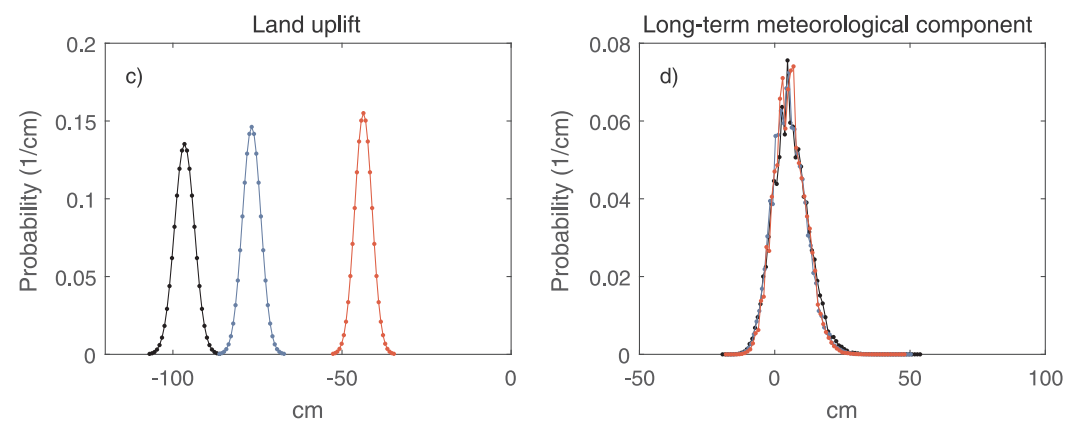


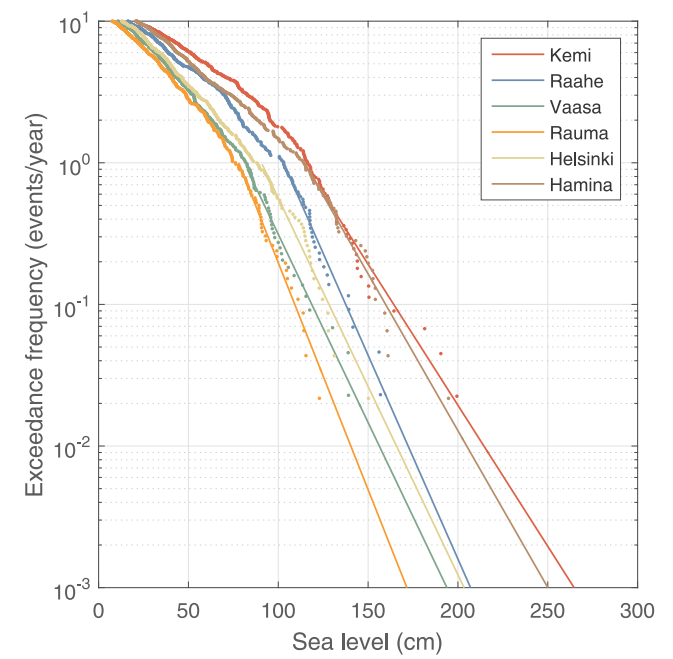

Fig. 6. Short-term sea level distributions $h_{s}$, i.e. observed monthly maxima in 1971-2016 (dots) relative to the estimated long-term mean sea level $h_{m}$, and exponential distributions fitted to the observations for six tide gauges on the Finnish coast.

agreement with the simulated distribution, while Fréchet and Gumbel extrapolations led to an overestimation. The exponential distribution is chosen in this paper, because it leads to slightly higher values and is thus a safer choice regarding flood risk estimates.

The exponential distributions are fitted to the sea level values with return periods of one year or longer. Such values can be considered to represent extreme events. It is also obvious that the observed exceedance frequencies do not follow the exponential function on shorter return periods (Fig. 6). The exponential fit and the observations are then merged into one distribution, using the fit for return periods longer than a year and the observed distribution for shorter return periods. The result is called simply the short-term sea level distribution (or variation) from now on.

\subsection{Flood probability distributions}

We estimate flooding probabilities in the future by combining the long-term scenarios of mean sea level $h_{m}$ with the short-term sea level variations $h_{s}$. Two assumptions are made: 1 ) the distribution of the short-term variations will not change in the future, and 2) short-term and long-term variations are independent and their combination is the sum of these two random variables. For land uplift and regional sea level rise, the second assumption is nearly satisfied, and since these two are dominant factors in the long-term variations, we consider the second assumption reasonable. The first assumption is necessary, because future changes in short-term sea level variations are unknown.

The flood probability distributions are calculated for the years 2050 and 2100. For each tide gauge, we calculate the complementary cumulative distribution function $P(x)$ for the sea level values $x$ under investigation. First, for all possible mean sea levels $y_{j}$ we define the short-term sea level values $z_{j}$ that have to be exceeded in order to exceed the sea level $x$ :

$z_{j}=x-y_{j}$

Where the mean sea levels $y_{j}$ are taken at $10 \mathrm{~cm}$ intervals from the mean sea level distribution of the year and tide gauge in question.

Next, the exceedance probabilities $Q\left(z_{j}\right)$ corresponding to sea levels $z_{j}$ are interpolated from the complementary cumulative distribution function of the short-term sea level variations. Finally, the exceedance probability $P(x)$ for the sea level value $x$ is calculated by combining the probability $p\left(y_{j}\right)$ of the mean sea level $y_{j}$ and the exceedance probability $Q\left(z_{j}\right)$ of the short-term sea level $z_{j}$ by summing over all the combinations $\left(y_{j}, z_{j}\right)$ according to

$P(x)=\sum_{j} p\left(y_{j}\right) Q\left(z_{j}\right)$

Eq. (8) is valid under the assumption that long-term and short-term sea level variations are independent of each other. The exceedance probabilities $P(x)$ form the complementary cumulative distribution function for future flood heights at the tide gauge in question.

\section{Results}

\subsection{Distributions of mean sea level change}

The probabilistic sea level rise scenarios constructed in this study (Fig. 5b) give the following estimates of sea level rise in 2000-2100 (5-95\% ranges): $31-155 \mathrm{~cm}$ globally, $24-124 \mathrm{~cm}$ in the Gulf of Finland, $23-120 \mathrm{~cm}$ in the Bothnian Sea, and $21-114 \mathrm{~cm}$ in the Bothnian Bay. The results are well in accordance with those reported by Johansson et al. (2014) despite significant updates in the prediction ensemble and the regionalization methods.

After adding the effect of land uplift and long-term meteorological changes, we obtain estimates of mean sea level change $h_{m}$ in 2000-2100 for the Finnish tide gauges (Table 3). According to the average scenarios, the historical declining trend in mean sea level is expected to continue during the 21st century on the northern parts of the Finnish coastline (Bothnian Bay and Bothnian Sea), while mean sea level rise is expected in the Archipelago Sea and the Gulf of Finland. The rise is strongest in the eastern part of the Gulf of Finland, up to $33 \mathrm{~cm}$ in Hamina. According to the highest (95\%) scenarios, mean sea level will rise everywhere on the Finnish coast, varying from $21 \mathrm{~cm}$ near Vaasa to $90 \mathrm{~cm}$ in Hamina.

\subsection{Future flooding probabilities}

Future sea levels with certain exceedance frequencies can be determined from the flood probability distributions that combine mean sea level change and short-term variations. Examples of the flood probability distributions are shown for six locations for the years 2010 , 2050, and 2100 (Fig. 7). Sea levels corresponding to certain exceedance frequencies are listed in Table 4 for all stations.

The results indicate significant regional differences in future trends of coastal flooding risks. The coastal flood probabilities will considerably increase in the Gulf of Finland compared to present-day conditions, especially between 2050 and 2100 . For example, during the major coastal flood in January 2005, sea level reached $170 \mathrm{~cm}$ (N2000) in Helsinki, causing significant damage. According to our results, such a flood has an exceedance probability of 3 events per century at present, 4 events per century in 2050, and 50 events per century in 2100 in Helsinki. Thus, by the end of the century the conditions have changed so that such a flood would occur on average every second year.

In the Bothnian Sea and the Bothnian Bay, flooding risks will first diminish by 2050 because of stronger land uplift and slightly weaker regional sea level rise compared to the Gulf of Finland. However, the situation is expected to reverse towards the end of the century: by 2100 , flood probabilities are predicted to rise back to the present level or slightly above them in the Bothnian Bay and clearly above the present level in the Bothnian Sea.

\subsection{Effects of expert judgement}

Our method of constructing a probability distribution for regional sea level rise involves weighting the different scenarios in the prediction ensemble and applying a scaling function to those global predictions that cannot be regionalized otherwise (Section 2.3.1). The weights 

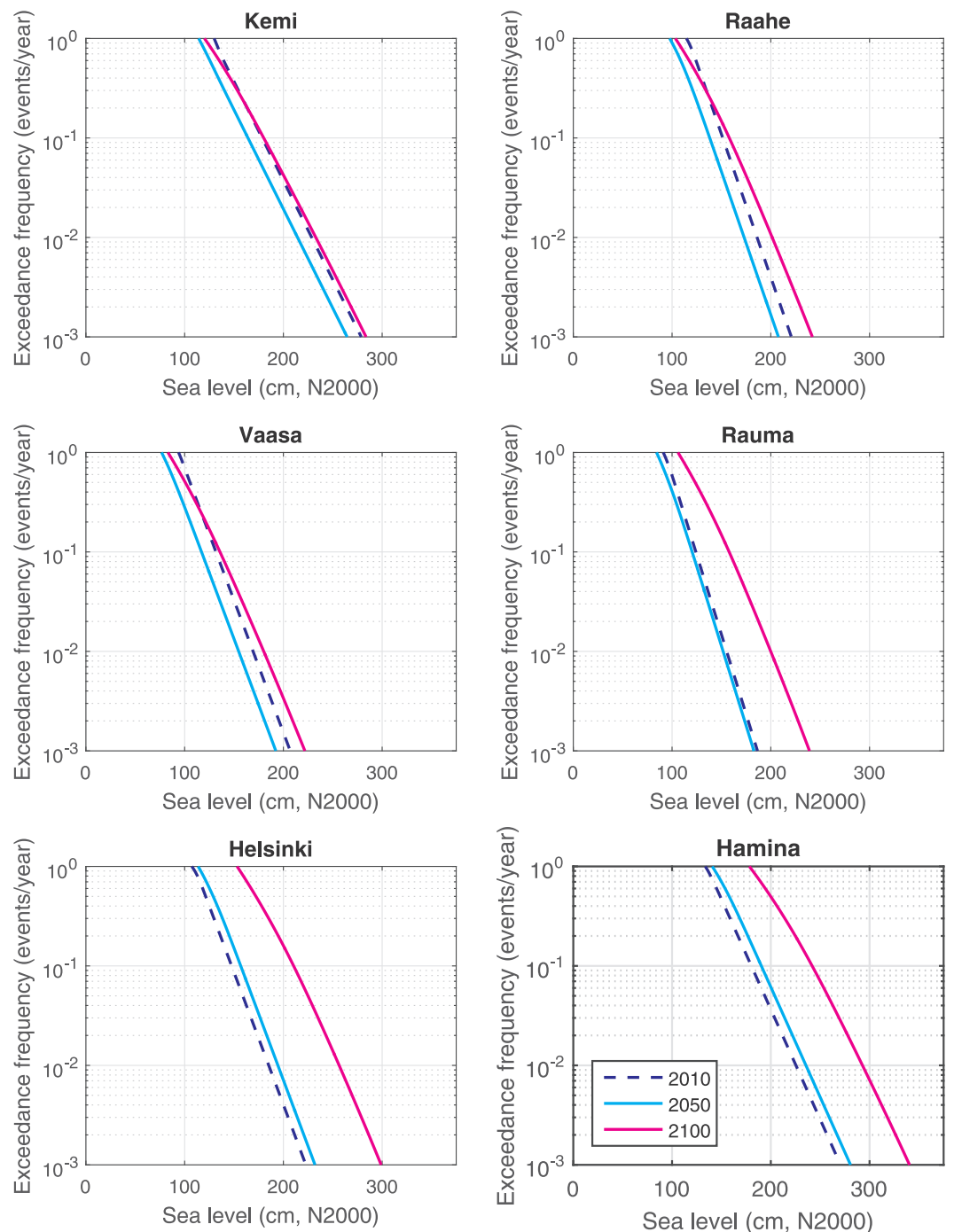

Fig. 7. Exceedance frequency distributions of high sea levels for 2010, 2050, and 2100 for six locations on the Finnish coast: Kemi, Raahe, Vaasa, Rauma, Helsinki, and Hamina.

and the scaling function are based on expert judgement and are thus debatable. Here we examine the effects of weighting and scaling on our results.

Comparing the results with weighting and no weighting (all predictions in Table 1 are given equal weight), we see that weighting somewhat lowers the total results: the estimated 5-95\% range of global sea level rise is $31-155 \mathrm{~cm}$ in the weighted case and $34-161 \mathrm{~cm}$ with equal weights (Table 5). The difference is similar in the regional estimates, which are lowered by ca. $5 \mathrm{~cm}$ due to the weights applied.

Scaling lowers the regional sea level rise estimates by ca. $20-30 \mathrm{~cm}$ at the high end. We give more credibility to the scaled estimates, as there is strong evidence that sea level rise on the Finnish coast will be below the global average due to the fingerprint effect. Thus, applying the global scenarios to the Finnish coast as such would result in an overestimate. The exact shape of the scaling function is less important: if the predictions are scaled with a constant coefficient of 0.8 , which is approximately the average ratio of regional to global sea level rise in our analysis, the results differ only a few centimetres from those presented in Table 5. The same is true if we drop the worst-case estimate from the dataset used to determine the scaling function (Fig. 2) or if we use a second-order fit.

We conclude that our results are not highly sensitive to the subjective choice of weights applied to different predictions. Scaling has a larger effect, but it has a physical justification and the details of the scaling method are of lesser importance.

\subsection{Comparison to other studies}

Probabilistic estimates of regional sea level rise have been recently emerging in the scientific literature. Kopp et al. (2014) published probabilistic sea level rise estimates for a global network of tide gauge locations, including all Finnish tide gauges. They estimate GMSL rise of up to $121 \mathrm{~cm}$ in the 21st century (95\% uncertainty limit of RCP8.5), which is lower than our upper limit of $155 \mathrm{~cm}$. Comparing their MSL estimates at the Finnish tide gauges with our results, their average (50\%) estimates of RCP8.5 are roughly similar to our average estimates, 
Table 4

Sea levels corresponding to different exceedance frequencies in 2010, 2050, and 2100 at the Finnish tide gauges.

\begin{tabular}{|c|c|c|c|c|c|c|c|c|c|}
\hline \multirow{3}{*}{$\begin{array}{l}\text { Exceedance } \\
\text { frequency } \\
\text { (events/ } \\
\text { year) } \\
\text { Year }\end{array}$} & \multicolumn{9}{|c|}{ Sea level (cm, N2000) } \\
\hline & \multicolumn{3}{|l|}{$1 / 20$} & \multicolumn{3}{|l|}{$1 / 50$} & \multicolumn{3}{|l|}{$1 / 100$} \\
\hline & 2010 & 2050 & 2100 & 2010 & 2050 & 2100 & 2010 & 2050 & 2100 \\
\hline Kemi & 194 & 179 & 196 & 214 & 199 & 217 & 229 & 214 & 233 \\
\hline Oulu & 192 & 179 & 198 & 211 & 198 & 218 & 226 & 213 & 233 \\
\hline Raahe & 162 & 149 & 172 & 176 & 163 & 189 & 186 & 173 & 201 \\
\hline Pietarsaari & 147 & 133 & 157 & 159 & 146 & 174 & 168 & 155 & 186 \\
\hline Vaasa & 143 & 128 & 149 & 158 & 143 & 167 & 169 & 155 & 180 \\
\hline Kaskinen & 140 & 129 & 160 & 154 & 143 & 177 & 164 & 154 & 190 \\
\hline Mäntyluoto & 134 & 127 & 163 & 147 & 140 & 179 & 157 & 150 & 192 \\
\hline Rauma & 134 & 130 & 171 & 146 & 142 & 188 & 155 & 152 & 200 \\
\hline Turku & 137 & 139 & 187 & 149 & 151 & 204 & 157 & 160 & 216 \\
\hline $\begin{array}{l}\text { Degerby } \\
\quad \text { (Föglö) }\end{array}$ & 117 & 118 & 166 & 129 & 130 & 183 & 138 & 139 & 195 \\
\hline Hanko & 134 & 142 & 200 & 146 & 154 & 217 & 155 & 163 & 229 \\
\hline Helsinki & 159 & 168 & 225 & 174 & 183 & 243 & 185 & 194 & 256 \\
\hline Hamina & 194 & 204 & 258 & 212 & 222 & 278 & 225 & 236 & 293 \\
\hline
\end{tabular}

while the average estimates of RCP4.5 are lower than ours by 10-15 cm. Kopp et al. (2014) give wider uncertainty ranges, however.

Grinsted et al. (2015) presented scenarios of sea level rise in northern Europe under RCP8.5. Their estimate of GMSL rise is higher than ours (5-95\% range $45-183 \mathrm{~cm}$ ). For estimating the high end of the distribution, they use the expert elicitation of Bamber and Aspinall (2013). Their best estimates are generally in agreement with our results, as they also project sea level fall in the Bay of Bothnia and sea level rise in the Gulf of Finland. Their best estimates are $10-15 \mathrm{~cm}$ higher, however, which is expected as their results only represent the high emission scenario RCP8.5. The largest differences are at the high end: the upper uncertainty limits of Grinsted et al. (2015) are roughly $0.5 \mathrm{~m}$ higher compared to our estimates, which is partially explained by their higher estimate of GMSL rise.

\section{Discussion and conclusions}

In this paper, we have presented a method of estimating future probabilities of coastal floods and applied the method to assess flooding risks on the Finnish coast in 2050 and 2100. Finland is relatively sheltered from the worst consequences of sea level rise, because the postglacial land uplift compensates for a significant portion of the projected rise. In addition, the contribution of the Greenland Ice Sheet is small in the Baltic Sea because of gravitational and crustal changes caused by ice sheet melt. Our results suggest that the historical decline in mean sea level will continue during the 21st century in the Gulf of Bothnia, while a reversing trend and sea level rise of $30-40 \mathrm{~cm}$ is expected in the Gulf of Finland. In the high end of the scenarios, mean sea level rise is projected for the entire Finnish coast, and sea level rise of close to $1 \mathrm{~m}$ is possible in the Gulf of Finland.

Our results of future flooding risks reflect the expected changes in mean sea level. Flooding risks are expected to considerably increase in the Gulf of Finland during the 21st century. The situation is different in the northern parts of Gulf of Bothnia, where flooding risks are expected to decrease by 2050 and increase to the present level or slightly above it by 2100 . In the Bothnian Sea, flooding probabilities are predicted to decrease or remain at the present level by 2050 , but to rise clearly above the present level by 2100 .

Our probability distributions of future flooding heights combine two distributions of different nature: we merge the uncertainty in the future mean sea level with the observed short-term variability. The further into the future we project, the wider the probability distribution will be because of the increasing uncertainty in the mean sea level scenario. The advantage of this method is that it results in only one sea level value corresponding to a certain return period, which is convenient for practical applications. However, it must be kept in mind that the increase in the flood probabilities from 2010 to 2100 is partly due to increasing uncertainty, not just the change in the physical process itself.

We note that our sea level rise distributions incorporate all emission pathways in the same probability distribution, in contrast to most studies. This choice was made because our work is targeted to decisionmakers determining safe building heights. For this purpose, a single probability distribution is more practical than giving multiple recommendations for different emission scenarios. When combining different emission scenarios presented in the literature we have treated them as equally likely, taking the average of the best estimates of different scenarios to represent the best estimate of the study in question.

We assumed that the short-term variations in sea level will stay unchanged in the future. This assumption may lead to uncertainties, because changes towards more extreme sea levels relative to the mean have been observed on the Finnish coast. The analysis of Johansson et al. (2001) does not suggest a steady increase in sea level maxima: the time series of annual maxima show periods of decrease and accelerated increase. Because the current climate models are not accurate enough to predict future changes in the short-term sea level variability, we have assumed as a first approximation that the variability during the last 46 years represents future conditions. Refining the method to incorporate also scenarios of future changes in short-term sea level variations is a topic for future work.

The second assumption in our method was that the distributions of long-term mean sea level change and the short-term variations are independent of each other. This assumption may not be fully accurate, because a change in sea level alters the bathymetry affecting e.g. seiche dynamics and wind setup, particularly in shallow areas. We estimate that this potential source of dependence between short-term and longterm variations has only a marginal effect in our results. The situation is different in the case of variations in the water volume of the Baltic Sea.

Table 5

Effects of weighting and scaling on the estimated sea level rise (cm) in 2000-2100 at different probability levels in the Gulf of Finland (GoF), the Bothnian Sea (BS), and the Bothnian Bay (BB) as well as globally. The results in bold are our best estimates.

\begin{tabular}{|c|c|c|c|c|c|c|c|c|c|c|c|c|}
\hline & & \multicolumn{5}{|c|}{ Scaling } & & \multicolumn{5}{|c|}{ No scaling } \\
\hline & & $5 \%$ & $17 \%$ & $50 \%$ & $83 \%$ & $95 \%$ & & $5 \%$ & $17 \%$ & $50 \%$ & $83 \%$ & $95 \%$ \\
\hline \multirow[t]{4}{*}{ Weighted } & & & & & & & Global & 31 & 46 & 73 & 115 & 155 \\
\hline & GoF & 24 & 39 & 64 & 98 & 124 & GoF & 24 & 40 & 68 & 107 & 141 \\
\hline & BS & 23 & 38 & 62 & 95 & 120 & BS & 24 & 39 & 67 & 106 & 140 \\
\hline & BB & 21 & 35 & 59 & 90 & 114 & $\mathrm{BB}$ & 22 & 37 & 65 & 103 & 139 \\
\hline \multirow[t]{4}{*}{ Equal weights } & & & & & & & Global & 34 & 51 & 82 & 126 & 161 \\
\hline & GoF & 27 & 42 & 69 & 104 & 129 & GoF & 28 & 45 & 76 & 118 & 152 \\
\hline & BS & 26 & 41 & 67 & 100 & 125 & BS & 27 & 44 & 76 & 117 & 152 \\
\hline & $\mathrm{BB}$ & 24 & 39 & 63 & 95 & 118 & $\mathrm{BB}$ & 25 & 43 & 74 & 116 & 152 \\
\hline
\end{tabular}


Short-term sea level variability can be expected to be larger when low pressure systems pass over the region, and such situations are correlated with westerly winds that push water into the sea through the Danish Straits. A blocking high pressure, on the other hand, empties the Baltic Sea, and it is usually associated with low winds and small shortterm sea level variations. We can therefore expect a positive correlation between short-term sea level variations and the meteorological component of long-term variations. However, the meteorological component is small in comparison to the large ranges of land uplift and sea level rise, and the assumption of independence between long-term and short-term sea level variations is justified as a first approximation. The relevance of the potential dependency could be modelled, which is also a topic for future work.

Using monthly maxima to construct the short-term sea level distributions has some limitations: statistics based on monthly maxima fail to take into account 1 ) that several high sea level events can occur during the same month, 2) the duration of the flood events, and 3) the effect of seasonal differences, i.e. the fact that sea levels in winter are higher on average than in summer, the variability is larger, and extreme values occur more often during winter on the Finnish coast. Therefore, using temporally denser sea level data would be worth examining. We chose the monthly maxima because they are sufficiently independent of each other while providing enough data to fit the distribution.

Probability distributions of future flooding risks are highly valuable for climate change adaptation in coastal planning and construction, because they enable flexible and cost-effective risk management in coastal areas. Buildings and structures whose operation is critical for society or whose loss would cause serious harmful consequences in case of flooding (e.g. hospitals, landfills or nuclear power plants) must be adapted to rarely occurring flood heights, whereas light and less expensive buildings can be constructed on lower ground. By constructing new buildings on sufficiently high ground, flood damage or costly flood protection measures can be avoided. However, setting the level of the recommendations for minimum building elevations is a matter of weighing the risks against extra costs incurred in the building phase. The latest recommendations for regular buildings in Finland were based on the $0.4 \%$ flooding levels ( 1 event per 250 years) in 2100 (Kahma et al., 2014). Any additional height to compensate for wave action is determined separately for each location and added to the recommendations.

Sea level rise and its uncertainties, especially the uncertain contribution from the Greenland and Antarctic ice sheets, are subject to active research. Information on future changes in short-term variability will also increase as climate models are improved. Therefore, flood risk evaluation is an ongoing process and results like those presented in this paper should be updated regularly when new information becomes available.

\section{Acknowledgements}

We thank Hanna Boman, Laura Tuomi, and Lauri Laakso for their helpful comments on the manuscript. The research was partially funded by the Ministry of Agriculture of Forestry, the Ministry of Environment, the City of Pori and the Centre for Economic Development, Transport and the Environment of Uusimaa. The work presented here was utilized in the implementation of the EU Floods Directive (2007/60/EC) in Finland.

\section{References}

Andersson, H.C., 2002. Influence of long-term regional and large-scale atmospheric circulation on the Baltic sea level. Tellus 54A, 76-88.

Bamber, J.L., Aspinall, W.P., 2013. An expert judgement assessment of future sea level rise from the ice sheets. Nat. Clim. Change 3, 424-427.

Church, J.A., Clark, P.U., Cazenave, A., Gregory, J.M., Jevrejeva, S., Levermann, A., Merrifield, M.A., Milne, G.A., Nerem, R.S., Nunn, P.D., Payne, A.J., Pfeffer, W.T., Stammer, D., Unnikrishnan, A.S., 2013. Sea level change. In: Stocker, T.F. (Ed.),
Climate Change 2013: The Physical Science Basis. Contribution of Working Group I to the Fifth Assessment Report of the Intergovernmental Panel on Climate Change. Cambridge University Press, Cambridge and New York, pp. 1137-1216.

Cubasch, U., Meehl, G.A., Boer, G.J., Stouffer, R.J., Dix, M., Noda, A., Senior, C.A., Raper, S., Yap, K.S., 2001. Projections of future climate change. In: Houghton, J.T. (Ed.), Climate Change 2001: The Scientific Basis. Contribution of Working Group I to the Third Assessment Report of the Intergovernmental Panel on Climate Change. Cambridge University Press, Cambridge and New York, pp. 526-582.

Dangendorf, S., Marcos, M., Wöppelmann, G., Conrad, C.P., Frederikse, T., Riva, R., 2017. Reassessment of 20th century global mean sea level rise. Proc. Natl. Acad. Sci. USA 114, 5946-5951.

DeConto, R.M., Pollard, D., 2016. Contribution of Antarctica to past and future sea-level rise. Nature 531, 591-597.

Ekman, M., 1996. A consistent map of the postglacial uplift of Fennoscandia. Terra Nova 8, 158-165.

Grinsted, A., Moore, J.C., Jevrejeva, S., 2010. Reconstructing sea level from paleo and projected temperatures 200-2100 CE. Clim. Dyn. 34, 461-472.

Grinsted, A., 2015. Projected change - sea level. In: The BACC II author team (Ed.), Second Assessment of Climate Change for the Baltic Sea Basin. Springer: Cham Heidelberg New York Dordrecht London, pp. 253-263.

Grinsted, A., Jevrejeva, S., Riva, R.E.M., Dahl-Jensen, D., 2015. Sea level rise projections for northern Europe under RCP8.5. Clim. Res. 64, 15-23.

Hay, C.C., Morrow, E., Kopp, R.E., Mitrovica, J.X., 2015. Probabilistic reanalysis of twentieth-century sea-level rise. Nature 517, 481-484.

Hill, E.M., Davis, J.L., Tamisiea, M.E., Lidberg, M., 2010. Combination of geodetic observations and models for glacial isostatic adjustment fields in Fennoscandia. J. Geophys. Res.: Solid Earth 115, B07403.

Horton, R., Herweijer, C., Rosenzweig, C., Liu, J., Gornitz, V., Ruane, A.C., 2008. Sea level rise projections for current generation CGCMs based on the semi-empirical method. Geophys. Res. Lett. 35, L02715.

Hünicke, B., Zorita, E., Soomere, T., Madsen, K.S., Johansson, M., Suursaar, Ü., 2015. Recent change - sea level and wind waves. In: The BACC II author team (Ed.), Second Assessment of Climate Change for the Baltic Sea Basin. Springer: Cham Heidelberg New York Dordrecht London, pp. 155-185.

Jevrejeva, S., Moore, J.C., Grinsted, A., 2010. How will sea level respond to changes in natural and anthropogenic forcing by 2100 ? Geophys. Res. Lett. 37, L07703.

Jevrejeva, S., Moore, J.C., Grinsted, A., 2012. Sea level projections to AD2500 with a new generation of climate change scenarios. Glob. Planet. Change 80, 14-20.

Jevrejeva, S., Grinsted, A., Moore, J.C., 2014a. Upper limit for sea level projections by 2100. Environ. Res. Lett. 9, 104008.

Jevrejeva, S., Moore, J.C., Grinsted, A., Matthews, A.P., Spada, G., 2014b. Trends and acceleration in global and regional sea levels since 1807. Glob. Planet. Change 113, $11-22$.

Johansson, M., Boman, H., Kahma, K.K., Launiainen, J., 2001. Trends in sea level variability in the Baltic Sea. Boreal Environ. Res. 6, 159-179.

Johansson, M., Kahma, K.K., Boman, H., Launiainen, J., 2004. Scenarios for sea level on the Finnish coast. Boreal Environ. Res. 9, 153-166.

Johansson, M.M., Pellikka, H., Kahma, K.K., Ruosteenoja, K., 2014. Global sea level rise scenarios adapted to the Finnish coast. J. Mar. Syst. 129, 35-46.

Johansson, M.M., Kahma, K.K., 2016. On the statistical relationship between the geostrophic wind and sea level variations in the Baltic Sea. Boreal Environ. Res. 21, 25-43.

Joughin, I., Smith, B.E., Medley, B., 2014. Marine ice sheet collapse potentially underway for the Thwaites Glacier Basin, West Antarctica. Science 344, 735-738.

Kahma, K., Pettersson, H., Boman, H., Seinä, A., 1998. Alimmat suositeltavat rakennuskorkeudet Pohjanlahden, Saaristomeren ja Suomenlahden rannikoilla. Finn. Inst. Mar. Res. Rep. 1998.

Kahma, K., Pellikka, H., Leinonen, K., Leijala, U., Johansson, M., 2014. Pitkän aikavälin tulvariskit ja alimmat suositeltavat rakentamiskorkeudet Suomen rannikolla. Finn. Meteorol. Inst. Rep. 2014, 6.

Katsman, C.A., Hazeleger, W., Drijfhout, S.S., van Oldenborgh, G.J., Burgers, G.J.H., 2008. Climate scenarios of sea level rise for the northeast Atlantic Ocean: a study including the effects of ocean dynamics and gravity changes induced by ice melt. Clim. Change 91, 351-374.

Katsman, C.A., Sterl, A., Beersma, J.J., van den Brink, H.W., Church, J.A., Hazeleger, W., Kopp, R.E., Kroon, D., Kwadijk, J., Lammersen, R., Lowe, J., Oppenheimer, M., Plag, H.-P., Ridley, J., von Storch, H., Vaughan, D.G., Vellinga, P., Vermeersen, L.L.A., van de Wal, R.S.W., Weisse, R., 2011. Exploring high-end scenarios for local sea level rise to develop flood protection strategies for a low-lying delta - the Netherlands as an example. Clim. Change 109, 617-645.

Kopp, R.E., Horton, R.M., Little, C.M., Mitrovica, J.X., Oppenheimer, M., Rasmussen, D.J., Strauss, B.H., Tebaldi, C., 2014. Probabilistic 21st and 22nd century sea-level projections at a global network of tide-gauge sites. Earth's Future 2, 383-406.

Kopp, R.E., Kemp, A.C., Bittermann, K., Horton, B.P., Donnelly, J.P., Gehrels, W.R., Hay, C.C., Mitrovica, J.X., Morrow, E.D., Rahmstorf, S., 2016. Temperature-driven global sea-level variability in the Common Era. Proc. Natl. Acad. Sci. USA 113, E1434-E1441.

Lidberg, M., Johansson, J.M., Scherneck, H.-G., Davis, J.L., 2007. An improved and extended GPS-derived 3D velocity field of the glacial isostatic adjustment (GIA) in Fennoscandia. J. Geod. 81, 213-230.

Lisitzin, E., 1962. Some characteristics of the variation in the water volume in the Baltic as a function of air pressure gradient changes. Soc. Sci. Fenn. Comment. Phys.-Math XXVI (9), 1-15.

Lisitzin, E., 1964. Contribution to the knowledge of land uplift along the Finnish coast. Fennia 89, 1-22.

Lisitzin, E., 1974. Sea-Level Changes. Elsevier Oceanography Series 8, Amsterdam, 
Oxford, New York.

Medvedev, I.P., Rabinovich, A.B., Kulikov, E.A., 2013. Tidal oscillations in the Baltic Sea, Mar. Phys. 53, 596-609.

Meehl, G.A., Stocker, T.F., Collins, W.D., Friedlingstein, P., Gaye, A.T., Gregory, J.M., Kitoh, A., Knutti, R., Murphy, J.M., Noda, A., Raper, S.C.B., Watterson, I.G., Weaver, A.J., Zhao, Z.-C., 2007. Global climate projections. In: Solomon, S. (Ed.), Climate Change 2007: The Physical Science Basis. Contribution of Working Group I to the Fourth Assessment Report of the Intergovernmental Panel on Climate Change. Cambridge University Press, Cambridge and New York, pp. 747-846.

Mengel, M., Levermann, A., Frieler, K., Robinson, A., Marzeion, B., Winkelmann, R., 2016. Future sea level rise constrained by observations and long-term commitment. Proc. Natl. Acad. Sci. USA 113, 2597-2602.

Mercer, J.H., 1978. West Antarctic ice sheet and $\mathrm{CO}_{2}$ greenhouse effect: a threat of disaster. Nature 271, 321-325.

Mitrovica, J.X., Tamisiea, M.E., Davis, J.L., Milne, G.A., 2001. Recent mass balance of polar ice sheets inferred from patterns of global sea-level change. Nature 409, 1026-1029.

Neumann, G., 1941. Eigenschwingungen der Ostsee. Aus dem Arch. der Dtsch. Seewarte und Des. Mar. 61 (4), 1-57.

Parjanne, A., Huokuna, M. (Eds.), 2014. Tulviin varautuminen rakentamisessa - opas alimpien rakentamiskorkeuksien määrittämiseksi ranta-alueilla [Flood Preparedness in Building - Guide for Determining the Lowest Building Elevations in Shore Areas]. Ympäristöopas [In Finnish with English Summary].

Pfeffer, W.T., Harper, J.T., O'Neel, S., 2008. Kinematic constraints on glacier contributions to 21st-century sea level rise. Science 321, 1340-1343.

Rahmstorf, S., 2007. A semi-empirical approach to projecting future sea-level rise. Science 315, 368-370.

Rignot, E., Mouginot, J., Morlighem, M., Seroussi, H., Scheuchl, B., 2014. Widespread, rapid grounding line retreat of Pine Island, Thwaites, Smith, and Kohler glaciers, West Antarctica, from 1992 to 2011. Geophys. Res. Lett. 41, 3502-3509.

Saaranen, V., Lehmuskoski, P., Rouhiainen, P., Takalo, M., Mäkinen, J., Poutanen, M., 2009. The new Finnish height reference N2000. In: Drewes, H., (ed.), Geodetic Reference Frames: IAG Symposium. Springer, Munich, Germany, pp. 297-302.

Samuelsson, M., Stigebrandt, A., 1996. Main characteristics of the long-term sea level variability in the Baltic Sea. Tellus 48A, 672-683.

Schoof, C., 2007. Ice sheet grounding line dynamics: steady states, stability, and hysteresis. J. Geophys. Res. 112, F03S28.

Simpson, M.J., Breili, K., Kierulf, H.P., 2014. Estimates of twenty-first century sea-leve changes for Norway. Clim. Dyn. 42, 1405-1424.

Slangen, A.B.A., Carson, M., Katsman, C.A., Van de Wal, R.S.W., Köhl, A., Vermeersen, L.L.A., Stammer, D., 2014. Projecting twenty-first century regional sea-level changes. Clim. Change 124, 317-332.

Särkkä, J., Kahma, K.K., Kämäräinen, M., Johansson, M.M., Saku, S., 2017. Simulated extreme sea levels at Helsinki. Boreal Environ. Res. 22, 299-315.

Tamisiea, M.E., Mitrovica, J.X., Davis, J.L., Milne, G.A., 2003. Long wavelength sea level and solid surface perturbations driven by polar ice mass variations: fingerprinting Greenland and Antarctic ice sheet flux. Space Sci. Rev. 108, 81-93.

Vermeer, M., Kakkuri, J., Mälkki, P., Boman, H., Kahma, K.K., Leppäranta, M., 1988. Land uplift and sea level variability spectrum using fully measured monthly means of tide gauge readings. Finn. Mar. Res. 256, 1-75.

Vermeer, M., Rahmstorf, S., 2009. Global sea level linked to global temperature. Proc. Natl. Acad. Sci. USA 106, 21527-21532.

Witting, R., 1911. Tidvattnen i Östersjön och Finska viken. Fennia 29, 2.

Wübber, C., Krauss, W., 1979. The two-dimensional seiches of the Baltic Sea. Oceanol. Acta 2, 435-446. 

(C)2020 Authors. CC Attribution 4.o License.

Reprinted, with kind permission, from Natural Hazards and Earth System Sciences Discussions doi: 10.5194/nhess-2020-3 



\title{
Meteotsunami occurrence in the Gulf of Finland over the past century
}

\author{
Havu Pellikka ${ }^{1}$, Terhi K. Laurila ${ }^{1}$, Hanna Boman ${ }^{1}$, Anu Karjalainen ${ }^{1}$, Jan-Victor Björkqvist ${ }^{1}$, and \\ Kimmo K. Kahma ${ }^{1}$ \\ ${ }^{1}$ Finnish Meteorological Institute, P.O. Box 503, FI-00101 Helsinki, Finland
}

Correspondence: Havu Pellikka (havu.pellikka@fmi.fi)

\begin{abstract}
We analyse changes in meteotsunami occurrence over the past century (1922-2014) in the Gulf of Finland, Baltic Sea. A major challenge for studying these short-lived and local events is the limited temporal and spatial resolution of digital sea level and meteorological data. To overcome this challenge, we examine archived paper recordings from two tide gauges, Hanko for 1922-1989 and Hamina for 1928-1989, from the summer months of May-October. We visually inspect the recordings to ect rapid sea level variations, which are then digitized and compared to air pressure observations from nearby stations. The data set is complemented with events detected from digital sea level data 1990-2014 by an automated algorithm. In total, we identify 121 potential meteotsunami events. Over $70 \%$ of the events could be confirmed to have a small jump in air pressure occurring shortly before or simultaneously with the sea level oscillations. The occurrence of meteotsunamis is strongly connected with lightning over the region: the number of cloud-to-ground flashes over the Gulf of Finland were on average over ten times higher during the days when a meteotsunami was recorded compared to days with no meteotsunamis in May-October. On a monthly level, statistically significant differences between meteotsunami months and other months were found in the number of CG flashes, convective available potential energy (CAPE), and temperature. Meteotsunami occurrence over the past century shows a statistically significant increasing trend in Hamina, but not in Hanko.
\end{abstract}

Copyright statement. TEXT

\section{Introduction}

On 29 July 2010, in Pellinki, in the Porvoo archipelago, Gulf of Finland, a summer resident witnessed an exceptional event:

"I have spent all my summers in Pellinki, now for the 50th time, and from 1989 in this place. During that time I have of course seen the water rise, fall and flow in various ways, but what I saw on 29 July was something totally new. When I stepped out of the door on that beautiful and calm morning I heard an exceptional sound, like a foaming torrent. The sound came from the nearby strait, which is rather shallow, perhaps $20 \mathrm{~cm}$ at normal water level, and about 80 metres long. The water was indeed flowing as if in a small rapids and formed clear waterfalls when it ran out at both ends of the strait. From 
the waterline on the rocks and rocky shores, I saw that the water had gone down about $40 \mathrm{~cm}$ in a very short time. I decided to photograph the events because they felt really exceptional. [...] My impression is that during that time [40 min] the water rose and fell about $40 \mathrm{~cm} \mathrm{3-4} \mathrm{times.} \mathrm{In} \mathrm{particular,} \mathrm{the} \mathrm{waves} \mathrm{rose} \mathrm{very} \mathrm{rapidly,} \mathrm{in} \mathrm{2-3} \mathrm{minutes."} \mathrm{(Eyewitness} \mathrm{report,}$ translated from Finnish)

Similar observations were reported from three different locations along the Finnish coastline on the same day, and more reports followed on 8 August 2010 and 4 June 2011. Data from coastal observation stations confirmed the eyewitness observations: tide gauges recorded rapid sea level oscillations, coinciding with sudden jumps in air pressure. Radar imagery revealed that the oscillations were small meteotsunamis caused by squall lines or gust fronts propagating above the sea at a speed close to the long-wave speed in the sea (Pellikka et al., 2014).

Meteotsunamis, or meteorological tsunamis, are long waves created through air-sea interaction (Monserrat et al., 2006). They occur on shallow sea areas all around the world and can be several metres high in extreme cases, with periods ranging from a few minutes to a few hours. The formation of a notable meteotsunami requires several coinciding factors:

1. An air pressure disturbance travels above a water body, creating a small initial wave.

2. The wave is amplified by air-sea interaction, e.g. through the Proudman resonance: the speed of the disturbance matches the long-wave speed in the sea, which depends on water depth $(v=\sqrt{g h}$, where $g$ is acceleration due to gravity and $h$ is water depth).

3. When the wave arrives at the coast, its height is further amplified by the coastal topography through shoaling, refraction, and internal oscillations in a semi-enclosed bay or harbour.

Meteotsunamis are subject to a recent upsurge in research activity worldwide, especially in the Mediterranean (e.g. Vilibić and Šepić 2009; Vilibić et al. 2014; Bechle et al. 2015; Pattiaratchi and Wijeratne 2015; Vilibić and Šepić 2017). Several studies have examined meteotsunami occurrence in different parts of the world ocean and developed methods to recognize meteotsunamis in past sea level observations (e.g. Pattiaratchi and Wijeratne 2014; Šepić et al. 2015; Masina et al. 2017; Olabarrieta et al. 2017; Dusek et al. 2019). However, sea level time series of a sufficiently high resolution (preferably 1 min; Leonard 2006) are typically rather short, 5-10 years.

The occurrence of meteotsunamis depends on the occurrence as well as on the speed, direction, and intensity of certain atmospheric phenomena, which in turn can be affected by regional climate variability and long-term changes in climate. For example, Olabarrieta et al. (2017) examined 20 years of tide gauge observations from the northeastern Gulf of Mexico and found a correlation between ENSO (El Niño - Southern Oscillation) and meteotsunami activity in the region. Typical atmospheric disturbances that create meteotsunamis under specific conditions include passing fronts, squalls, storms and atmospheric gravity waves (Monserrat et al., 2006). The three meteotsunami events observed in Finland in 2010-2011 were created by a squall line, a gust front, and a cold front passage (Pellikka et al., 2014).

In Finland, the phenomenon aroused interest after the meteotsunami observations of 2010-2011. The speed and height of the reported oscillations (up to $1 \mathrm{~m}$ in 5-15 minutes) clearly exceed normal sea level variations on the Finnish coast. A similar 
event in 1924 in the Gulf of Finland was documented by Renqvist (1926), and there are descriptions from coastal residents and seafarers of encounters with such waves. On German-speaking Baltic coasts the phenomenon is known as Seebär and in Swedish as sjösprång. While the phenomenon is not unprecedented on the Finnish coast, the eyewitness observations in 2010 and 2011 came after several decades of no reported occurrences.

In this paper, we study changes in meteotsunami occurrence in the Gulf of Finland, northern Baltic Sea (Fig. 1) over the past century. Recent scientific literature lacks a systematic study of meteotsunami occurrence in the Baltic Sea, and to our knowledge, changes in meteotsunami occurrence in a century time scale have not been previously studied anywhere in the world. Traditionally, the sampling interval of tide gauge observations has been 1 hour or longer, which is too coarse for detecting variations in the tsunami frequency range. To overcome this limitation, we must turn to the original tide gauge charts, where sea level variations have been recorded as a continuous curve on paper. As the processing of the charts involves a lot of manual work, the study area is restricted to the Gulf of Finland, where most known meteotsunami cases on the Finnish coast have been observed.

Our research is motivated by coastal safety: while the events observed in Finland in 2010-2011 did not cause notable damage, strong oscillations in sea level may endanger coastal traffic and infrastructure in extreme cases. Understanding the frequency and intensity of meteotsunamis on the Finnish coast is crucial for estimating the probability of such events.

We aim to answer these questions: i) Is it possible to detect past meteotsunami events based on the available sea level and meteorological data sets? ii) How typical and how strong are meteotsunamis in the Gulf of Finland? iii) Are there temporal trends or variations in the frequency of meteotsunamis? iv) Is the occurrence of meteotsunamis correlated with some atmospheric variables?

\section{Observations and data quality}

\subsection{Sea level observations}

Sea level data used in this study comes from three tide gauges on the southern coast of Finland (Fig. 1): Hanko (founded in 1887), Helsinki (1904), and Hamina (1928). The quality controlled digital sea level database from these tide gauges contains values for every four hours before 1970, and hourly values after that. Hence, the temporal resolution of this database does not allow the study of meteotsunami waves that typically have much shorter periods. A digital data set, sampled every 15 minutes, is available from 1980 onwards (Fig. 2). From 2004 onwards, there is digital data sampled every minute; however, the longer 15 min data set was used in this study as we are interested in long-term changes in meteotsunami occurrence.

High-resolution sea level data before the 1980s is available only on the original tide gauge charts, which are currently stored in the archives of the Finnish Meteorological Institute (FMI). From the 1920s to the 1990s, most Finnish tide gauges were equipped with a Renqvist-Witting recording device (Fig. 3). The device recorded the movements of the float swimming in the tide gauge well by transferring the motion to a wheel (circumference $1 \mathrm{~m}$ ), on which 10 pens of different colours were fastened. As the wheel turned, the pens plotted the motion on a paper roll in real size (scale 1:1) so that each colour corresponds to a 
certain decimetre of sea level height (Stenij, 1932). The 4-hourly and hourly values in the digital sea level database have been sampled manually from these paper charts.

The principal data set used in this study consists of the original paper charts from the Hanko and Hamina tide gauges from the periods 1922-1989 and 1928-1989, respectively (Fig. 2). The Helsinki tide gauge was the only Finnish tide gauge not equipped with a Renqvist-Witting device. Instead, a Reitz recorder was used. The glass plate used to read sea level values from Reitz paper charts has not been preserved, and the data is arduous to use. In addition, the small scale of variation in Reitz paper charts hinders the recognition of meteotsunamis. For these reasons, paper charts from the Helsinki tide gauge have been excluded from the study. Digital 15 min sea level data from 1980 onwards is used from all three tide gauges.

Analysing the charts includes a lot of manual work. To restrict the amount of data, only the ice-free summer months from May to October were considered. Even though the possibility of meteotsunamis occurring in winter cannot be ruled out, such cases are expected to be very rare on the Finnish coast (see Sect. 5 for discussion).

A notable meteotsunami with a height of up to $1 \mathrm{~m}$ was observed in the western part of the Gulf of Finland and in the Archipelago Sea on 15 May 1924 (Renqvist, 1926). After this event, the Finnish Institute of Marine Research started to collect observations of sudden sea level changes by preparing a specific form for the purpose and distributing it to pilot stations and lighthouses in Finland. Approximately 60 such forms from 1924 to 1938 are stored in the archives of FMI. Among these, 14 forms contain information of possible meteotsunamis in addition to the well-documented case of 15 May 1924. We use these eyewitness observations as an additional source of information on meteotsunami occurrence in the 1920s and 1930s.

\subsection{Atmospheric data}

We use air pressure observations from coastal stations to confirm the meteorological origin of the possible meteotsunamis discovered in the sea level data. The stations nearest to the tide gauges are Russarö (Hanko), Harmaja (Helsinki), and Rankki (Kotka, about 24km southwest from Hamina; Fig. 1). Original paper barograms from these stations exist in the archives of FMI and have been used when available. Digital 10 minute data is available from 2001-2006 onwards depending on the station and was used to confirm some of the recent events.

To study the connections between meteotsunami occurrence and climatological factors, meteotsunami observations are compared to monthly climatological data and lightning observations. The North Atlantic Oscillation (NAO) indices are obtained from a data set by Cropper et al. (2014) which includes daily NAO indices since 1850. From this data set, we calculated monthly mean values. The NAO index is calculated from the sea level pressure difference between the Azores and Iceland. It describes large-scale atmospheric conditions in the region, controlling the strength and direction of westerlies and storm tracks.

The atmospheric parameters of mean sea level pressure, 10 metre wind speed, 2 metre temperature and dew point temperature, as well as convective available potential energy (CAPE) are obtained from reanalysis data. Two different data sets were used: ERA-20C (covering the years 1922-2010) and ERA-Interim (1979-2014), both produced by the European Centre for Medium-Range Weather Forecasts. ERA-20C has a horizontal resolution of around $125 \mathrm{~km}$ or $1.125^{\circ}$ (Poli et al., 2013) whereas in ERA-Interim, it is around $80 \mathrm{~km}$ or $0.75^{\circ}$ (Dee et al., 2011). We have interpolated the ERA-Interim data to match 
the resolution of ERA-20C so that the grid points are compatible. The reanalysis data was averaged spatially over the Gulf of Finland region $\left(20.25-30.375^{\circ} \mathrm{E}, 59.0625-61.3125^{\circ} \mathrm{N}\right)$. Finally, daily and monthly mean values were calculated.

We also compare the meteotsunami occurrence to lightning observations. From 1887, thunderstorm days in Finland have been observed by humans, and in 1960-1998 with an automatic flash counter network. From 1998 onwards, in addition to the number of flashes, also the location information of the flash is obtained due to a modern lightning locating system (Mäkelä et al., 2014). In this study, we compared the meteotsunami data set to the yearly number of thunder days (1922-2014) and the yearly number of cloud-to-ground (CG) flashes over the whole continent of Finland (1960-2014). In addition, from 1998-2014, we calculated daily and monthly CG flash numbers in the Gulf of Finland region $\left(20-30^{\circ}\right.$ E, $\left.58-62^{\circ} \mathrm{N}\right)$.

\subsection{Data quality}

The 15 min digital sea level data (1980-2014) is raw data that has not been subject to thorough processing and quality control. However, the data was browsed through visually, and clearly erroneous spikes and shifts were removed before further analysis. Possible problems in the data are documented and relatively easy to trace. In Hanko and Hamina, the 15 min observations were digitized by a human-assisted computer program over the period 1980-1987. When comparing these observations to the data that was digitized from the tide gauge charts for this study, it was noted that not all high-frequency oscillations are accurately reproduced in the $15 \mathrm{~min}$ data during this period.

On some occasions, sea level variations recorded at the tide gauges have been suppressed due to blockages or damage in the underwater pipe connecting the tide gauge well to the sea. When the pipe is partially blocked, the water level in the well adjusts slowly to sea level changes, and there is a time lag and attenuation in the recorded sea level fluctuations. We refer to this attenuation as damping. In the worst case, damping is so heavy that all sea level variations have been levelled out. Damping particularly hinders the study of high-frequency sea level variations such as meteotsunamis.

To determine the periods when the high-frequency oscillations were damped in the digital 15 min tide gauge records (19802014), a spectral analysis was performed. The variance of oscillations with a frequency higher than $0.25 \mathrm{~h}^{-1}$ (period shorter than 4 hours) was integrated from the variance density spectra calculated from seven day time series. The high spatial and temporal variability in the recorded shorter oscillations was evident already from a visual inspection of the high-frequency variance. However, to quantify the results, a value exceeded $95 \%$ of the time (i.e. the $5^{\text {th }}$ percentile) was determined from the Hamina tide gauge records, which were the visually least disturbed. This value was found to be $0.016 \mathrm{~m}^{2}$. The same value was then used in the analysis of all tide gauges. The results were not very sensitive to the exact choice of this cut-off value, but produced the same main findings regardless.

The time series was then divided into blocks of four consecutive values, thus representing a time period of four weeks. If the variance was below the $5^{\text {th }}$ percentile over half of the time, the four week period was flagged as a "damped period". While this definition is somewhat arbitrary, a couple of results are evident: i) the records from Hanko are clearly damped during 1985-1989, and ii) none of the three tide gauges suffered from significant damping since the beginning of the 2000s. The maintenance of the tide gauges was considerably improved when automatically registering devices were installed. Before that 
time reacting to problems was slow, because the tide gauge charts were collected once a month and it took almost one month to read and analyse them.

It was not possible to perform a similar spectral analysis for the data before the 1980s (i.e. the tide gauge charts). However, an experienced person can estimate the degree of damping visually by comparing the behaviour of the sea level curve to normal variations. The degree of damping in the paper charts was roughly estimated as percentages from no damping (0\%) to total damping (100\%) per each month. For the overlapping period 1980-1989 for which there is both digital and chart data available, the two independent methods of estimating the degree of damping (spectral and visual) produced comparable results.

In the tide gauge charts of Hanko (1922-1989), $3.2 \%$ of the data was missing and $17.3 \%$ damped, while in Hamina (19281989), $2.0 \%$ of data was missing and $12.4 \%$ damped. Thus, about $20 \%$ of the Hanko tide gauge charts and $14 \%$ of the Hamina charts were either missing or so heavily damped that they were unusable for meteotsunami detection. In the 15 min data from 1990-2014, the proportion of missing or damped data was small: $6 \%$ in Hanko, 0 \% in Helsinki, and $1 \%$ in Hamina.

\section{Identifying meteotsunamis}

There is no universal definition or criteria for what qualifies as a meteotsunami, as nearly all sea level variations in the tsunami frequency range are of atmospheric origin. In this study, the metrics used for detecting meteotsunamis are the period and height of the sea level oscillations and the occurrence of a rapid change in air pressure simultaneously with the sea level event. For the tide gauge charts, possible cases were selected visually and digitized manually. High-frequency events in the 15 min data were detected with an algorithm that resulted in a manageable amount of possible events to be confirmed or rejected through a visual inspection of air pressure data. A detailed description of the procedures is given in the sections below.

The periods of meteotsunami waves are in the tsunami frequency range spanning from a few minutes to a few hours (Monserrat et al., 2006). The heights of the events were determined from high-pass filtered time series, because slower variations influence the water level also during the meteotsunamis. The filter removed the information below a cut-off frequency of $0.25 \mathrm{~h}^{-1}$ in Fourier space and was implemented using the Fast Fourier Transform (FFT).

For each potential meteotsunami event identified in the data, we defined three different height metrics after high-pass filtering the sea level data:

1. $h_{\max }$ : The height (top to bottom) of the largest individual wave.

2. $h_{t o t}$ : The total range of sea level variation during the event.

3. $\eta_{\max }$ : The rise above zero in the filtered signal.

\subsection{Detecting meteotsunamis in tide gauge charts}

Rapid sea level variations appear as dense oscillations on the Renqvist-Witting tide gauge charts and are easy to locate by visual inspection (see Fig. 3 for an example). To find all possible meteotsunami events, we carried out a three-phase inspection: 
1. The tide gauge charts were browsed visually. Exceptionally rapid sea level changes were selected for further inspection and photographed. Loose criteria were applied at this stage in order not to miss any potential meteotsunamis.

2. From the cases selected in the visual browsing, we digitized those where the sea level behaviour clearly differs from surrounding variations. The digitization was carried out manually with a glass plate designed for reading values from tide gauge charts. The time scale printed on the plate has markings every 1 hour, meaning that times between the full hours needed to be estimated.

3. From the digitized cases, we excluded those that were too slow (period longer than $2-3$ hours) or too small ( $h_{\max }<12$ $\mathrm{cm}$ in Hanko, $<20 \mathrm{~cm}$ in Hamina).

The criterion for wave height was set as follows: First, we determined $h_{\max }$. Second, we plotted a histogram of all events at the tide gauge in question (not shown) and set the height threshold at the peak of the distribution. It was assumed that the frequency of occurrence should decrease towards higher values and that the peak in the distribution was an artifact resulting from some of the smaller events being included in the visual browsing and some of them being omitted. Therefore, the peak represents the wave height which is clearly visually distinguishable from other sea level variations.

The height criterion applied was different for each tide gauge, because there is large spatial variability in the high-frequency part of the sea level spectrum depending on the location and structure of the tide gauge. In particular, the height of a meteotsunami depends on the bathymetry of the coastal waters and varies strongly from point to point on the coastline. Highest oscillations are observed in bays and inlets whose resonant properties amplify the arriving wave (Monserrat et al., 2006).

Finally, the atmospheric origin of the sea level oscillations was confirmed by examining barograms from nearby coastal stations for rapid changes in air pressure. The events were interpreted as meteotsunamis if there was evidence of a pressure jump occurring within a few hours of the sea level oscillations. A small proportion of the events were excluded because there was no indication of air pressure changes. The pressure jumps accompanying meteotsunamis are small (typically only $1-3 \mathrm{hPas}$, Monserrat et al. 2006; Pellikka et al. 2014) and not always easy to distinguish especially if the quality of the air pressure curve is poor. Therefore, and because of missing air pressure data, a notable portion of the potential meteotsunami events was left unconfirmed.

\subsection{Detecting meteotsunamis in digital sea level data}

Potential meteotsunami events were searched automatically from the $15 \mathrm{~min}$ sea level data (1980-2014) of all three tide gauges. It is possible to detect rapid variations in the tsunami frequency range even in 15 min data, but the heights of the events will be somewhat underestimated because of the temporal resolution. First, we calculated the heights of all individual waves $\left(h_{\max }\right)$ from the high-pass filtered time series, using the differences of adjacent data points to locate wave tops and bottoms (where the derivative of the signal changes sign). From this wave height data set we picked the waves that exceed the height threshold determined in the tide gauge chart analysis: $12 \mathrm{~cm}$ for Hanko and $20 \mathrm{~cm}$ for Hamina. For Helsinki, no charts were analysed, so we applied a threshold of $10 \mathrm{~cm}$. The spectra of the filtered 15 min data from Helsinki and Hanko are rather similar, while in Hamina, there is clearly more variability in the sea level signal in the tsunami frequency range (standard deviations of the 
filtered signal are $0.45 \mathrm{~cm}$ for Hanko, $0.41 \mathrm{~cm}$ for Helsinki, and $0.92 \mathrm{~cm}$ for Hamina). To remove multiple occurrences of the same event in the data set, we selected the events that have a time difference of at least $12 \mathrm{~h}$.

As with the chart events, we examined the air pressure data and categorized the events as confirmed, not confirmed, or uncertain depending on whether there was evidence of rapid changes in air pressure. Two examples of the detected meteotsunamis

5 are given in Fig. 4. The first one was digitized from the Hanko tide gauge charts (the original chart is shown in Fig. 3). The second was detected from the $15 \mathrm{~min}$ sea level data from Hamina. Both cases have been confirmed from air pressure data.

\section{Results}

\subsection{Meteotsunami occurrence in the Gulf of Finland}

For Hanko and Hamina, the methods described above result in two time series of meteotsunamis: one based on original tide gauge charts (1922/1928-1989) and the other on 15 min sea level data (1980-2014). A small number of events (4 from Hanko and 6 from Hamina) were excluded from the data set because there was no evidence of rapid changes in air pressure during the event despite air pressure data being available.

As there is a 10 year overlap (1980-1989) in the time series, we can compare the performance of the different methods of identifying meteotsunamis in the data. For Hamina, the results are nearly identical: both the visual viewing and the automatic detection identify 7 events over the decade, of which 6 are given by both methods. For Hanko, data from the 1980s is largely missing (Fig. 5) and there are only three possible events found in the tide gauge charts, of which one is detected in the 15 min data. The other two are not properly recorded in the $15 \mathrm{~min}$ observations because of data quality problems (see Sect. 2.3). Because of these problems, we use the results from the tide gauge charts in the final data set for the 1980s. Nevertheless, the good agreement between the two data sets in Hamina indicates that both the visual viewing and the automatic detection of rapid variations are effective methods of identifying meteotsunamis in the data and the results can be combined with reasonable confidence.

The detection algorithm successfully identifies the known meteotsunami events from the Gulf of Finland, on 29 July 2010 and on 8 Aug 2010 (Pellikka et al., 2014). The event on 15 May 1924 reported by Renqvist (1926) is also detected from the Hanko tide gauge charts, but the maximum wave height is only $8.3 \mathrm{~cm}$, falling below the height threshold. This highlights the limitations imposed by the sparse observation network: even during strong meteotsunami events, when eyewitnesses have observed exceptional sea level oscillations over a large area (exceeding $1 \mathrm{~m}$ in some places), the wave heights observed at the tide gauges can be small (Renqvist, 1926; Pellikka et al., 2014).

Only one of the events detected from the tide gauge charts (24 May 1926 in Hanko) was mentioned in old eyewitness reports collected by the Finnish Institute of Marine Research (Sect 2.1). According to the report from the lighthouse of Seivästö, in the easternmost part of the Gulf of Finland, sea level oscillations of ca. $40 \mathrm{~cm}$ occurred within a few minutes in the morning after a nightly thunderstorm. Rapid oscillations were recorded at the Hanko tide gauge during the night, but their height did not exceed the threshold and this event is thus not included in the final data set. 
The number of detected events in the different data sets are given in Table 1. In total, 45 potential meteotsunamis were detected from Hanko (1922-2014) and 65 from Hamina (1928-2014). In addition, 25 events were detected in the 15 min observations from Helsinki (1980-2014). When we take into account that 14 of the events were detected at more than one station, we get a total number of 121 separate events. Over $70 \%$ of the events were confirmed from air pressure observations: there is an abrupt change of $1-3 \mathrm{hPa}$ occurring simultaneously with the sea level oscillations or shortly before. The remaining events were left unconfirmed because air pressure data of sufficiently high resolution is not available.

Figure 5 shows all detected and potential meteotsunamis together with the amount of missing data per year. Missing data includes also the data which is so heavily damped that rapid variations in sea level have not been recorded correctly. Detecting trends in the time series is hampered by gaps in the high-frequency data, most notably in the 1940s and 1980s in Hanko and in the 1960s in Hamina.

While the time series from Hanko shows no apparent trend, meteotsunamis in Hamina seem to be more common over the latter half of the century than over the first half. Excluding the years with over $80 \%$ of missing data, the slope of a least squares fit for Hamina is 4.4 times larger than for Hanko. The positive slope at Hamina is also statistically significant at a level of (at least) $p=0.01$, while the weaker positive slope at Hanko is statistically significant only at $p=0.15$.

Typical heights of the detected meteotsunamis $\left(h_{\max }\right)$ range between 10-30 cm (Fig. 6). The largest meteotsunami heights were found in Hamina, where the highest event was $51 \mathrm{~cm}\left(h_{\max }\right)$, and the smallest in Helsinki, where the highest event was $17 \mathrm{~cm}$. The maximum variations during the events $\left(h_{t o t}\right)$ are only slightly higher than the height of the maximum single wave. The maximum water level elevation above zero during the event $\left(\eta_{\max }\right)$ is typically roughly half of the height of the maximum variation. This indicates that the high-frequency variations during the meteotsunamis are usually quite symmetrical with respect to the still water level determined by the slower changes (that have here been filtered out). There is no statistically significant linear trend for the magnitude of the meteotsunamis $\left(h_{\max }\right)$.

\subsection{Comparison with atmospheric data}

To study the connections between meteotsunami occurrence and the meteorological conditions, we calculated the number of meteotsunamis occurring during each summer month (May-Oct) from 1922 to 2014. Of the 558 months over this time period, 91 months $(16 \%)$ have at least one potential meteotsunami occurrence. The number of events in different calendar months is as follows: 26 events in May, 20 in June, 37 in July, 18 in August, 10 in September, and 10 in October.

We then calculated the mean values of certain atmospheric parameters in the two sets of months: those that have at least one meteotsunami occurrence and those that have none (Table 2). The null hypothesis that the means of these two sets are equal was tested with the two-sample $t$-test, using Satterthwaite's approximation in order not to assume equal variances. The main conclusions remain unchanged even if the potential (uncertain) meteotsunamis are excluded from the data set.

Statistically highly significant $(p<0.001)$ differences were found in the number of CG flashes in the Gulf of Finland area as well as CAPE, which is a measure of convective instability in the atmosphere and often used as an indicator of thunderstorm potential. The mean values of both the temperature and dew point temperature also show a statistically significant $(p<0.01)$ 
difference, the temperatures being higher during months when meteotsunamis have been registered. Mean sea level pressure, wind speed and the NAO index did not show a statistically significant difference.

Similarly, we divided the years 1922-2014 in two categories - with meteotsunamis and no meteotsunamis - and tested the difference in the yearly number of thunder days over Finland. The difference was significant at $5 \%$ level but not at $1 \%$ level.

5 However, there was no significant difference in the number of CG flashes recorded over the whole continent of Finland in a yearly time scale. Finally, the summer days (May-Oct) over the period May 1998-Oct 2014 were divided in two categories. The daily number of CG flashes was clearly and statistically significantly $(p<0.001)$ larger during the days of meteotsunami occurrence than during normal conditions.

The lightning observations have a strong connection with meteotsunami occurrence. In the summers of 1998-2014, from which there is daily lightning data available from the Gulf of Finland, there have been 42 days on which a potential meteotsunami has occurred in the area. CG flashes have been observed on all of these days except one (30 July 2010), and even on that date, the meteotsunami in Hamina was recorded just after midnight after an active thunder day (5 378 CG flashes observed on 29 July 2010). On average, the number of flashes during a meteotsunami day was roughly 10 times that of an average summer day in the region.

\section{Discussion and conclusions}

We detected 121 potential meteotsunami events at the tide gauges of Hanko, Helsinki, and Hamina in the Gulf of Finland over the past century (1922-2014). Over $70 \%$ of the events were confirmed to coincide with a rapid change in air pressure. Typical wave height registered at the tide gauges was $10-30 \mathrm{~cm}$. However, higher oscillations have probably occurred in bays, harbours, and straits where the coastal bathymetry has amplified the waves. The events detected in the tide gauge data are comparable with the observed meteotsunami events in 2010 and 2011, during which eyewitnesses reported oscillations of up to over $1 \mathrm{~m}$.

Before the recent eyewitness observations of meteotsunamis in Finland (Pellikka et al., 2014), Finnish sea level researchers did not receive such reports from the general public for at least 30 years. It remains unclear why, as the data shows that meteotsunamis are not a new phenomenon on the Finnish coast and there is no significant trend in the height of these waves. Lower reporting threshold in the era of Internet and mobile phones is one possible explanation for the upsurge in eyewitness reports. However, data from Hamina gives a statistically significant increasing trend in the number of meteotsunamis over the past century. Further research is needed to explain this increase and the fact that no such trend is observed at Hanko. As the height of a meteotsunami is sensitive to the interplay of the arriving wave and coastal bathymetry, it may well be that changes in the propagation direction of atmospheric disturbances result in differing trends at different locations.

There is an identifiable difference between typical heights at the three locations, with Hamina having the largest meteotsunamis and Helsinki the smallest. However, different degrees of damping due to the blockage of the pipe connecting the tide gauge to the sea were found at all stations. It cannot be conclusively determined to which degree this damping may have affected the amplitude of rapid variations even for data that was not discarded as erroneous. The use of 15 min observations is also expected to introduce a slight negative bias, as the maximum values of 15 min observations are smaller compared to denser 
data. That said, the finding placing the highest variations in Hamina is expected based on its geographical location furthest in to the Gulf of Finland.

Statistically highly significant differences between months when meteotsunamis have been registered compared to normal conditions were found in the number of lightnings over the Gulf of Finland as well as CAPE, which is an indicator of summertime thunderstorm potential. Monthly mean temperatures also show a statistically significant difference. These differences may be partially connected to meteotsunamis being more prevalent during the hottest summer months of June-August and less common in September-October, but the results do demonstrate a strong connection between thunderstorms and meteotsunami occurrence. On a daily level, the cloud-to-ground flash numbers were over ten times larger during days when meteotsunamis have been registered than otherwise. It can be concluded that meteotsunamis in the Gulf of Finland are practically always connected with thunderstorms.

The study was restricted to summer months (May-October) to keep the amount of data archaeology manageable. Meteotsunamis are expected to be rare in winter, as thunderstorms in Finland are predominantly a summertime phenomenon (Punkka and Bister, 2015). Furthermore, ice cover in the sea reduces the effect of atmospheric disturbances on the sea surface and attenuates especially high-frequency sea level variations. The highest sea levels usually occur in the wintertime on the Finnish coast, and thus meteotsunamis do not generally coincide with annual sea level maxima. This lowers the probability of an extremely high sea level occurring as a combination of a storm surge and a meteotsunami, but quantifying this probability is a topic for further work. Considering coastal safety, an important question is whether meteotsunamis are included in distributions of maximum sea levels. As meteotsunamis are relatively rare, it may be that none have contributed to the monthly maxima, which are often used to estimate coastal flooding risks.

20 The results show that meteotsunamis as a phenomenon are far more common in the Baltic Sea than previously thought, even though few events are strong enough to be widely noticed or potentially harmful. Many open questions remain regarding Baltic meteotsunamis. An essential topic for future work is to better establish the connections between meteotsunamis and weather patterns. After that, atmospheric parameters could be used to estimate the probability of meteotsunami occurrence and eventually to predict the events.

Data availability. The data that support the findings of this study are available on request from the corresponding author. Data usage is subject to conditions determined by the data policy of the Finnish Meteorological Institute.

Author contributions. KK and HP designed the study. HP analysed the digital sea level data and JVB performed the spectral analyses. AK and HB analysed the tide gauge charts and HP compiled the meteotsunami database. TL calculated the climatological parameters and HP analysed their connection to meteotsunami occurrence. HP wrote the manuscript with contributions from all coauthors. 
https://doi.org/10.5194/nhess-2020-3

This is just a preview and not the published preprint.

(c) Author(s) 2020. CC-BY 4.0 License.

(c) (1)

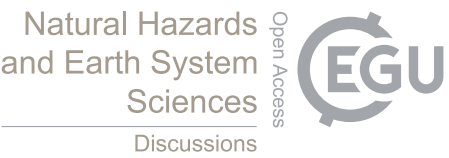

Competing interests. The authors declare no competing interests.

Acknowledgements. We wish to thank the numerous individuals who, over the decades, have worked to maintain the Finnish tide gauge network and sea level database and with their dedication ensured the high quality and preservation of the data. We are grateful to Pentti Pirinen and Achim Drebs for help with tracking air pressure data from the archives, and Simo Siiriä for technical help. Milla Johansson 5 provided valuable comments. This work was supported financially by VYR (State Nuclear Waste Management Fund) through SAFIR2018 (The Finnish Research Programme on Nuclear Power Plant Safety 2015-2018). The study has utilized research infrastructure facilities provided by FINMARI (Finnish Marine Research Infrastructure network). 


\section{References}

Bechle, A. J., Kristovich, D. A., and Wu, C. H.: Meteotsunami occurrences and causes in Lake Michigan, Journal of Geophysical Research: Oceans, 120, 8422-8438, 2015.

Cropper, T. E., Hanna, E., Valente, M. A., and Jónsson, T.: A Daily Azores-Iceland North Atlantic Oscillation Index back to 1850, https://doi.org/10.5281/zenodo.9979, https://doi.org/10.5281/zenodo.9979, 2014.

Dee, D., Uppala, S., Simmons, A., Berrisford, P., Poli, P., Kobayashi, S., Andrae, U., Balmaseda, M., Balsamo, G., Bauer, P., et al.: The ERA-Interim reanalysis: Configuration and performance of the data assimilation system, Quarterly Journal of the Royal Meteorological Society, 137, 553-597, 2011.

Dusek, G., DiVeglio, C., Licate, L., Heilman, L., Kirk, K., Paternostro, C., and Miller, A.: A meteotsunami climatology along the US East Coast, Bulletin of the American Meteorological Society, 100, 1329-1345, 2019.

Leonard, M.: Analysis of tide gauge records from the December 2004 Indian Ocean tsunami, Geophysical Research Letters, 33, L17 602, 2006.

Mäkelä, A., Enno, S.-E., and Haapalainen, J.: Nordic Lightning Information System: Thunderstorm climate of Northern Europe for the period 2002-2011, Atmospheric Research, 139, 46-61, 2014.

Masina, M., Archetti, R., Besio, G., and Lamberti, A.: Tsunami taxonomy and detection from recent Mediterranean tide gauge data, Coastal Engineering, 127, 145-169, 2017.

Monserrat, S., Vilibić, I., and Rabinovich, A.: Meteotsunamis: atmospherically induced destructive ocean waves in the tsunami frequency band, Natural Hazards and Earth System Sciences, 6, 1035-1051, 2006.

Olabarrieta, M., Valle-Levinson, A., Martinez, C. J., Pattiaratchi, C., and Shi, L.: Meteotsunamis in the northeastern Gulf of Mexico and their possible link to El Niño Southern Oscillation, Natural Hazards, 88, 1325-1346, 2017.

Pattiaratchi, C. and Wijeratne, E.: Observations of meteorological tsunamis along the south-west Australian coast, Natural hazards, 74, 281-303, 2014.

Pattiaratchi, C. B. and Wijeratne, E.: Are meteotsunamis an underrated hazard?, Philosophical Transactions of the Royal Society A: Mathematical, Physical and Engineering Sciences, 373, $20140377,2015$.

Pellikka, H., Rauhala, J., Kahma, K. K., Stipa, T., Boman, H., and Kangas, A.: Recent observations of meteotsunamis on the Finnish coast, Natural Hazards, 74, 197-215, 2014.

Poli, P., Hersbach, H., Tan, D. G. H., Dee, D., Thepaut, J.-J., Simmons, A., Peubey, C., Laloyaux, P., Komori, T., Berrisford, P., Dragani, R., Trémolet, Y., Hólm, E. V., Bonavita, M., Isaksen, L., and Fisher, M.: The data assimilation system and initial performance evaluation of the ECMWF pilot reanalysis of the 20th-century assimilating surface observations only (ERA-20C), Shinfield Park, Reading, 2013.

Punkka, A.-J. and Bister, M.: Mesoscale convective systems and their synoptic-scale environment in Finland, Weather and Forecasting, 30 , 182-196, 2015.

Renqvist, H.: Ein Seebär in Finnland. Zur Frage Nach der Entstehung der Seebären., Geografiska Annaler, 8, 230-236, 1926.

Šepić, J., Vilibić, I., Lafon, A., Macheboeuf, L., and Ivanović, Z.: High-frequency sea level oscillations in the Mediterranean and their connection to synoptic patterns, Progress in Oceanography, 137, 284-298, 2015.

Stenij, S. E.: Ein selbstschreibender Apparat für Ausmessung von Mareographenkurven, Societas Scientiarum Fennica: Commentationes physico-mathematicae, VI, 1932. 
https://doi.org/10.5194/nhess-2020-3

This is just a preview and not the published preprint.

(c) Author(s) 2020. CC-BY 4.0 License.

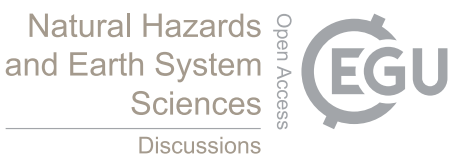

(c) (C)

Discussions

Vilibić, I. and Šepić, J.: Destructive meteotsunamis along the eastern Adriatic coast: Overview, Physics and Chemistry of the Earth, 34, 904-917, 2009.

Vilibić, I. and Šepić, J.: Global mapping of nonseismic sea level oscillations at tsunami timescales, Scientific Reports, 7, 40 818, 2017.

Vilibić, I., Monserrat, S., and Rabinovich, A. B.: Meteorological tsunamis on the US East Coast and in other regions of the World Ocean, 2014. 


\begin{tabular}{lccl}
\hline & Events & $h_{\max }>h_{t}$ & Confirmed \\
\hline Hanko & & & \\
Charts (1922-1989) & 39 & 31 & 20 \\
15 min (1990-2014) & & 14 & 11 \\
& & $\mathbf{4 5}$ & $\mathbf{3 1}(69 \%)$ \\
Hamina & & \\
Charts (1928-1989) & 44 & 31 & 18 \\
15 min (1990-2014) & & 34 & 26 \\
& & $\mathbf{6 5}$ & $\mathbf{4 4}(68 \%)$ \\
Helsinki & & \\
15 min (1980-2014) & & 25 & 24 \\
& & $\mathbf{2 5}$ & $\mathbf{2 4}(96 \%)$ \\
\hline
\end{tabular}

Table 1. Number of potential and confirmed meteotsunami events identified in the different data sets. The first column shows the number of events found on the tide gauge charts based on visual inspection. The second column gives the size of the final data set, which are events exceeding a station-specific height threshold $h_{t}$. Confirmed events have a rapid change in air pressure occurring simultaneously with the sea level oscillations. The rest could not be confirmed because of missing or inconclusive air pressure data. 


\begin{tabular}{llll}
\hline & Meteotsunami & No meteotsunami & Significance $(p)$ \\
\hline Yearly means & & & \\
Thunder days (1922-2014) & 11.5 & 9.9 & yes $(0.02)$ \\
CG flashes over Finland (1960-2014) & 137850 & 140007 & no \\
Monthly means & & & \\
MSLP (1922-2014), hPa & 1012.9 & 1013.6 & no \\
$T_{2 m}(1922-2014),{ }^{\circ} \mathrm{C}$ & 12.5 & 11.1 & yes $(0.006)$ \\
$D_{2 m}(1922-2014),{ }^{\circ} \mathrm{C}$ & 8.4 & 6.9 & yes $(0.004)$ \\
$U_{10 m}(1922-2014), \mathrm{m} \mathrm{s}^{-1}$ & 4.4 & 4.4 & no \\
CAPE (1922-2010), J kg ${ }^{-1}$ & 39.9 & 20.3 & yes $(<0.001)$ \\
NAO (1922-2014) & 0.12 & 0.04 & no \\
CG flashes over GoF $(1998-2014)$ & 23534 & 8159 & yes $(<0.001)$ \\
Daily means & & & yes $(<0.001)$ \\
CG flashes over GoF (1998-2014) & 4225 & 368 & \\
\hline
\end{tabular}

Table 2. Means of certain atmospheric variables on the years, months, or days when there is at least one meteotsunami occurrence and when there are none. The statistical significance of the difference is shown at $5 \%$ level. CG flash $=$ cloud-to-ground flash, MSLP $=$ mean sea level pressure, $T_{2 m}=$ temperature $(2 \mathrm{~m}), D_{2 m}=$ dew point temperature $(2 \mathrm{~m}), U_{10 \mathrm{~m}}=$ wind speed $(10 \mathrm{~m}), \mathrm{CAPE}=$ convective available potential energy, $\mathrm{NAO}=$ North Atlantic Oscillation, $\mathrm{GoF}=$ Gulf of Finland. 
https://doi.org/10.5194/nhess-2020-3

This is just a preview and not the published preprint.

(c) Author(s) 2020. CC-BY 4.0 License.

(c) (1)
Natural Hazards and Earth System

Sciences

Discussions

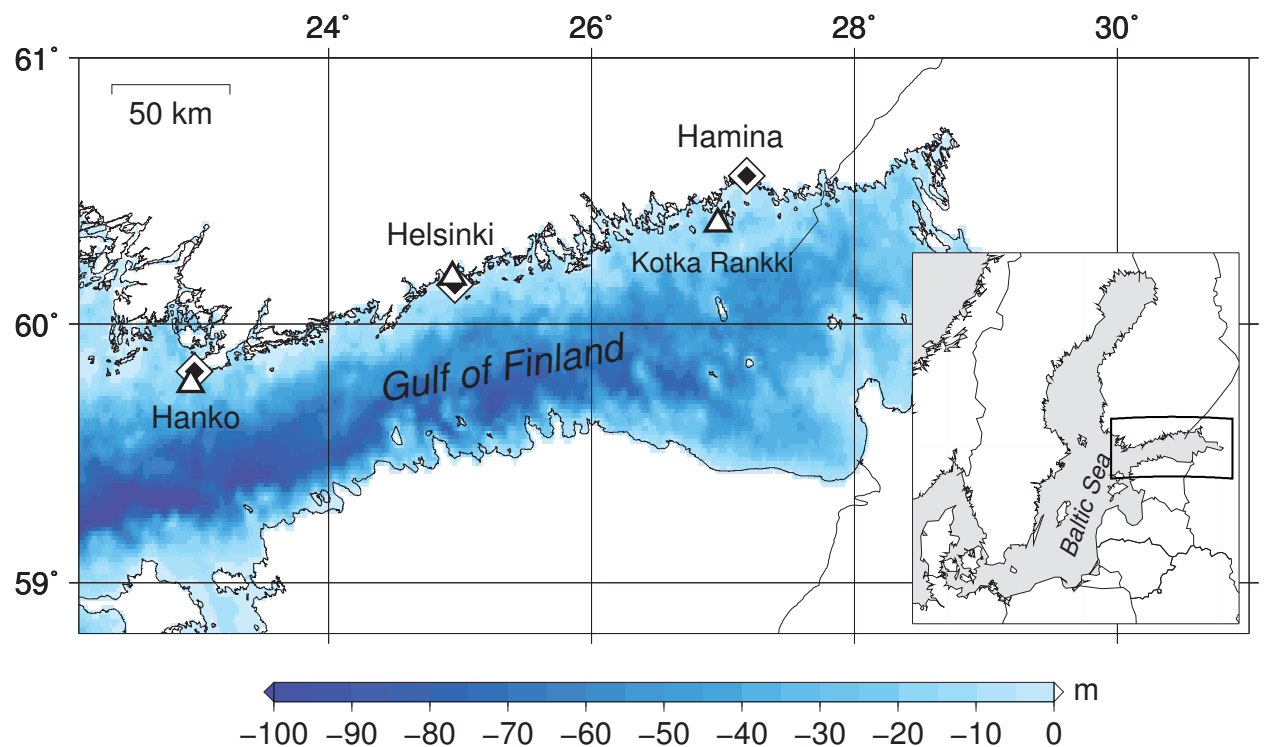

Figure 1. Bathymetric map of the study area, the Gulf of Finland in the Baltic Sea. Locations of the Finnish tide gauges are marked with diamonds. Meteorological stations, which provided the data used in this study, are marked with triangles. 
https://doi.org/10.5194/nhess-2020-3

This is just a preview and not the published preprint.

(c) Author(s) 2020. CC-BY 4.0 License.

(c) (1)
Natural Hazards and Earth System

Sciences

Discussions

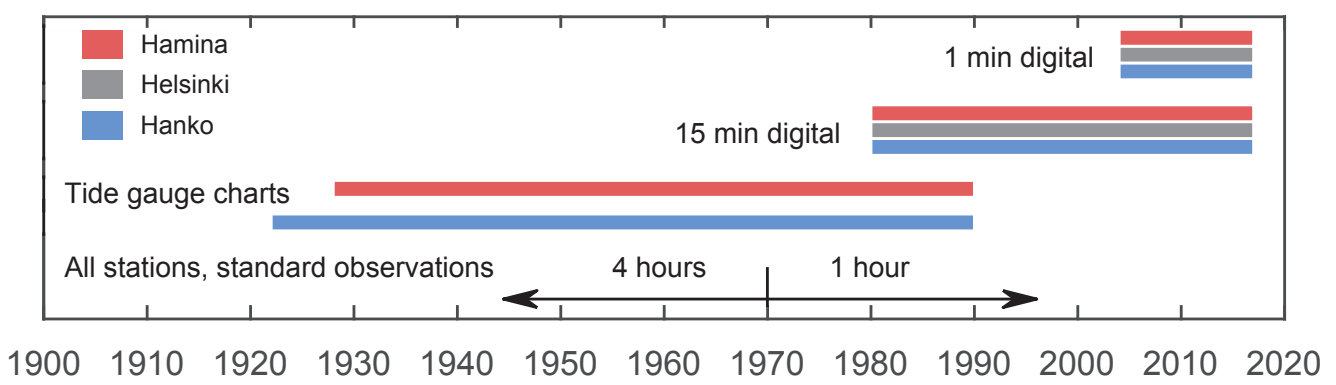

Figure 2. Sea level data available from the tide gauges of Hanko, Helsinki, and Hamina in the Gulf of Finland. Only selected events have been manually digitized from the tide gauge charts. 
https://doi.org/10.5194/nhess-2020-3

This is just a preview and not the published preprint.

(c) Author(s) 2020. CC-BY 4.0 License.

(c) (1)

\section{Natural Hazards and Earth System \\ Sciences

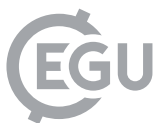

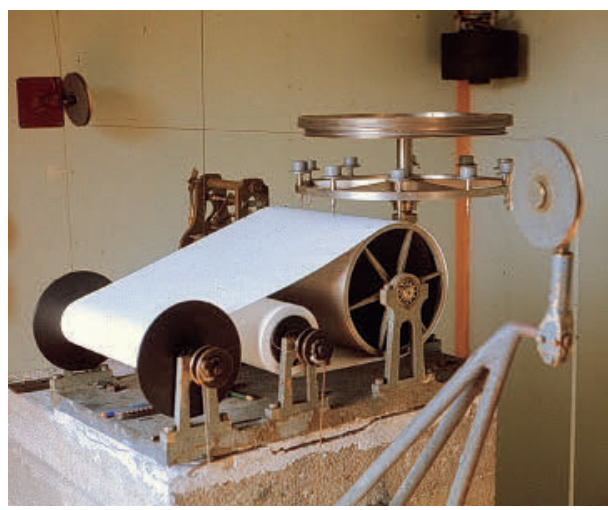

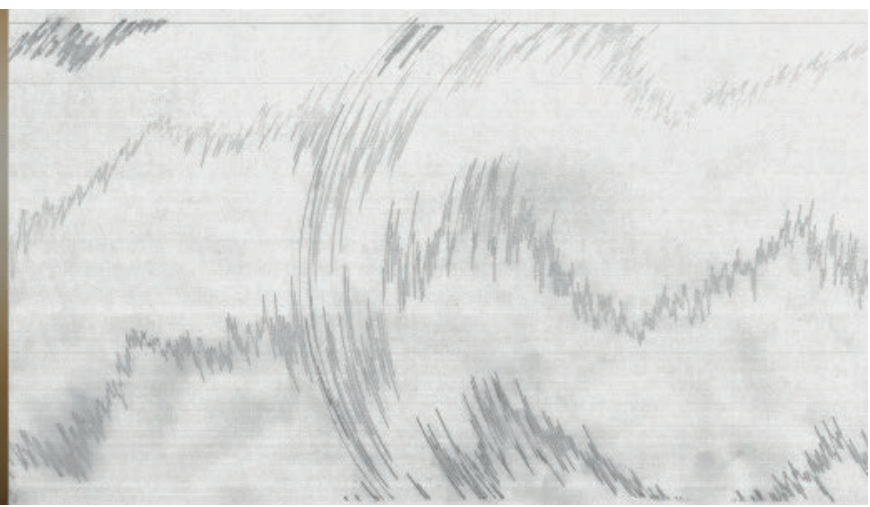

Figure 3. The Renqvist-Witting recording device used at most Finnish tide gauges from the 1920s to the early 1990s and an example of the paper charts recorded by the device at Hanko, showing a meteotsunami event on 9-10 May 1969. 

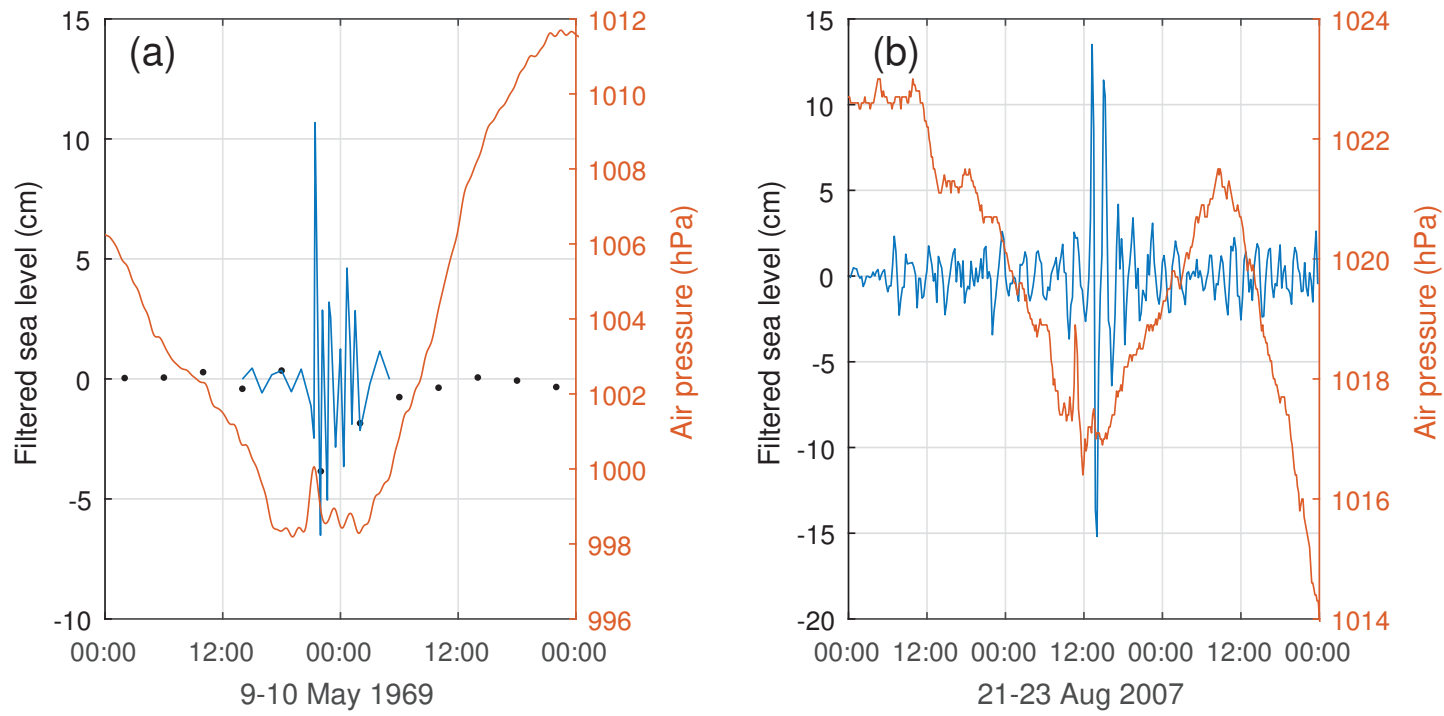

Figure 4. a) A meteotsunami in Hanko on 9-10 May 1969, visually identified and digitized from the tide gauge charts. Black dots show the standard $4 \mathrm{~h}$ sea level observations. Air pressure observations from Hanko Russarö, digitized from a paper barogram, are plotted in red. b) A meteotsunami in Hamina on 22 Aug 2007, automatically detected from the high-pass filtered 15 min sea level data. Air pressure observations from Kotka Rankki are plotted in red. 

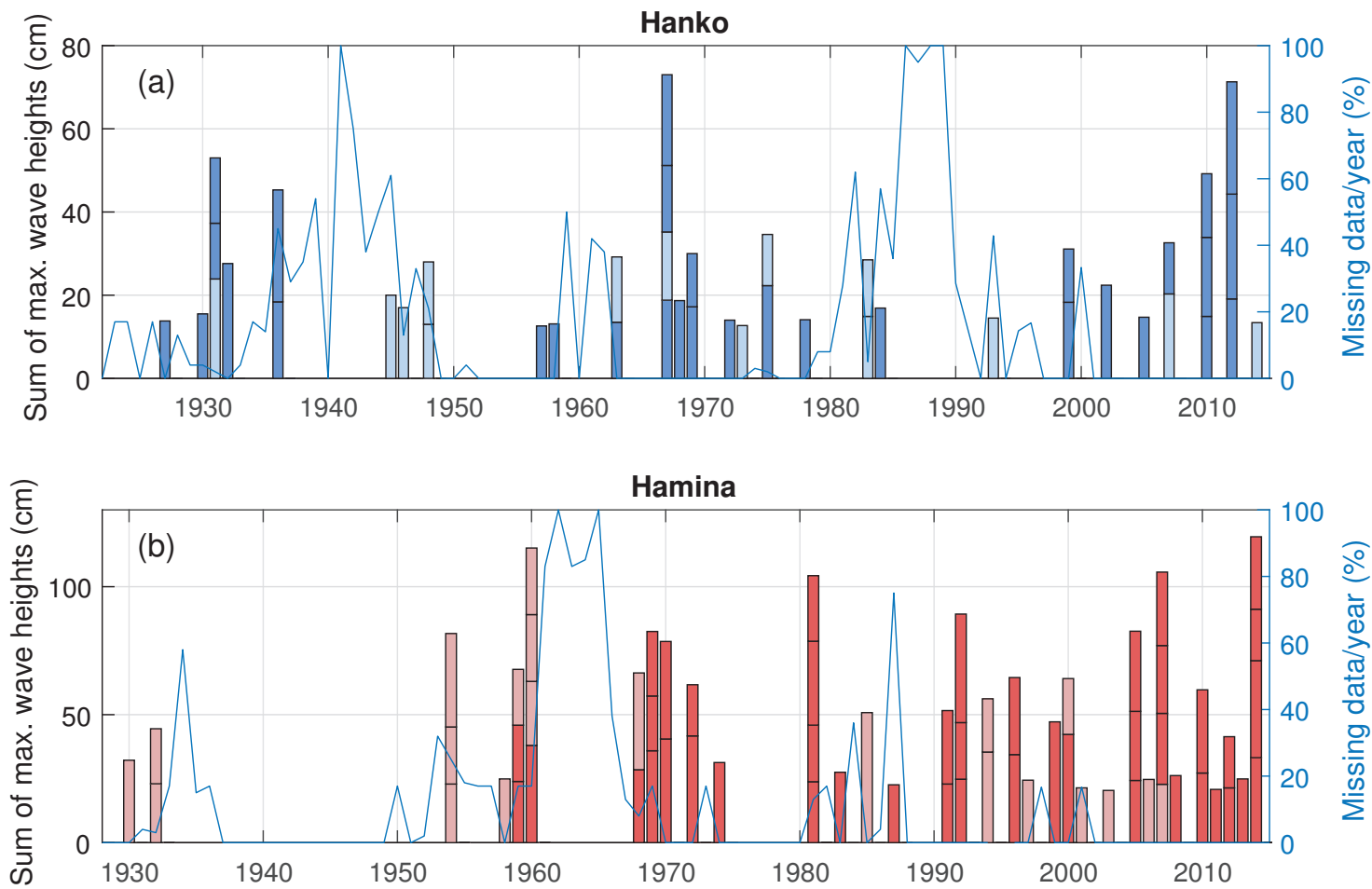

Figure 5. Meteotsunamis identified in the sea level data from the 1920s to 2014 for a) Hanko and b) Hamina. The events of each year are stacked so that the height of the column corresponds to the sum of maximum wave heights of the events during a given year. Darkcoloured events have been confirmed from air pressure data; the light-coloured events are potential meteotsunamis whose atmospheric origin is uncertain. The blue curves show the proportion of missing or damped data per year. 
https://doi.org/10.5194/nhess-2020-3

This is just a preview and not the published preprint.

(C) Author(s) 2020. CC-BY 4.0 License.

(c) (1)
Natural Hazards and Earth System

Sciences

Discussions
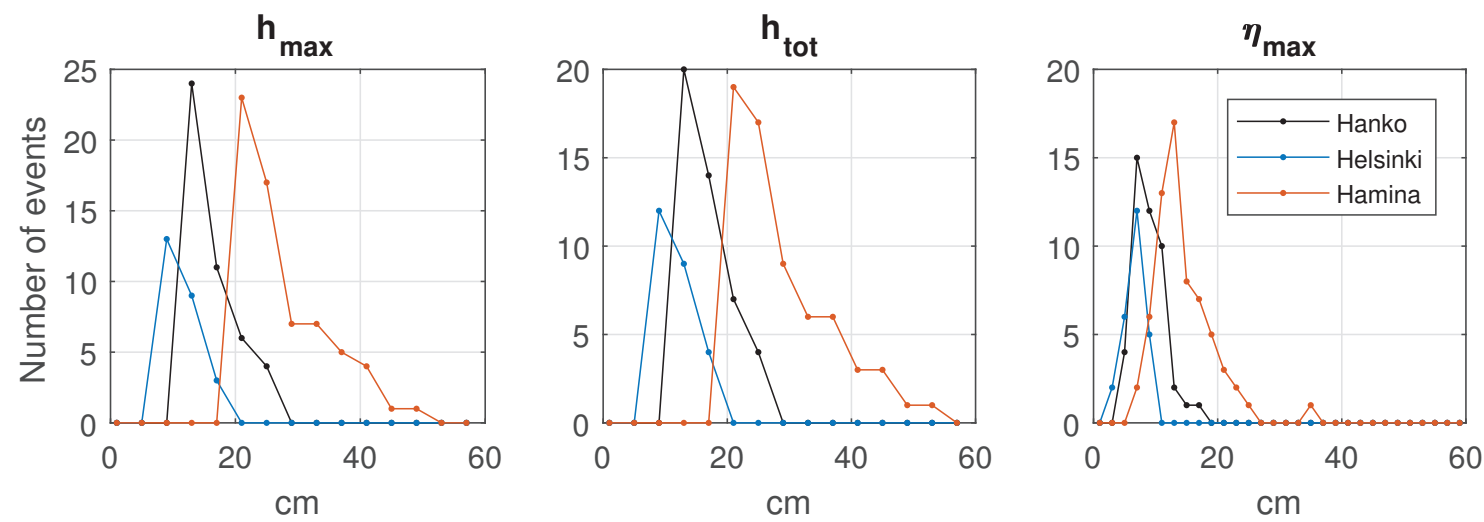

Figure 6. Histograms of meteotsunami heights, including both confirmed and potential events from all three stations: the maximum height of a single wave $h_{\max }$, the total range of variation $h_{t o t}$, and the maximum elevation $\eta_{\max }$. 
FINNISH METEOROLOGICAL INSTITUTE

Erik Palménin aukio 1

P.O. Box 503

FI-00560 HELSINKI

tel. +358 295391000

\section{WWW.FMI.FI}

FINNISH METEOROLOGICAL INSTITUTE CONTRIBUTIONS No. 167

ISSN 0782-6117

ISBN 978-952-336-111-9 (paperback)

ISBN 978-952-336-112-6 (pdf)

https://doi.org/10.35614/isbn.9789523361126 $\because .8$
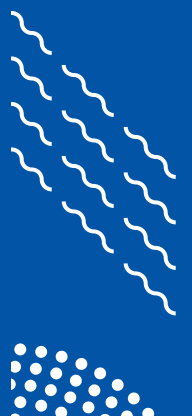